Summary Report of Responses of Key Resources to the 2000 Low Steady Summer Flow Experiment, along the Colorado River Downstream from Glen Canyon Dam, Arizona

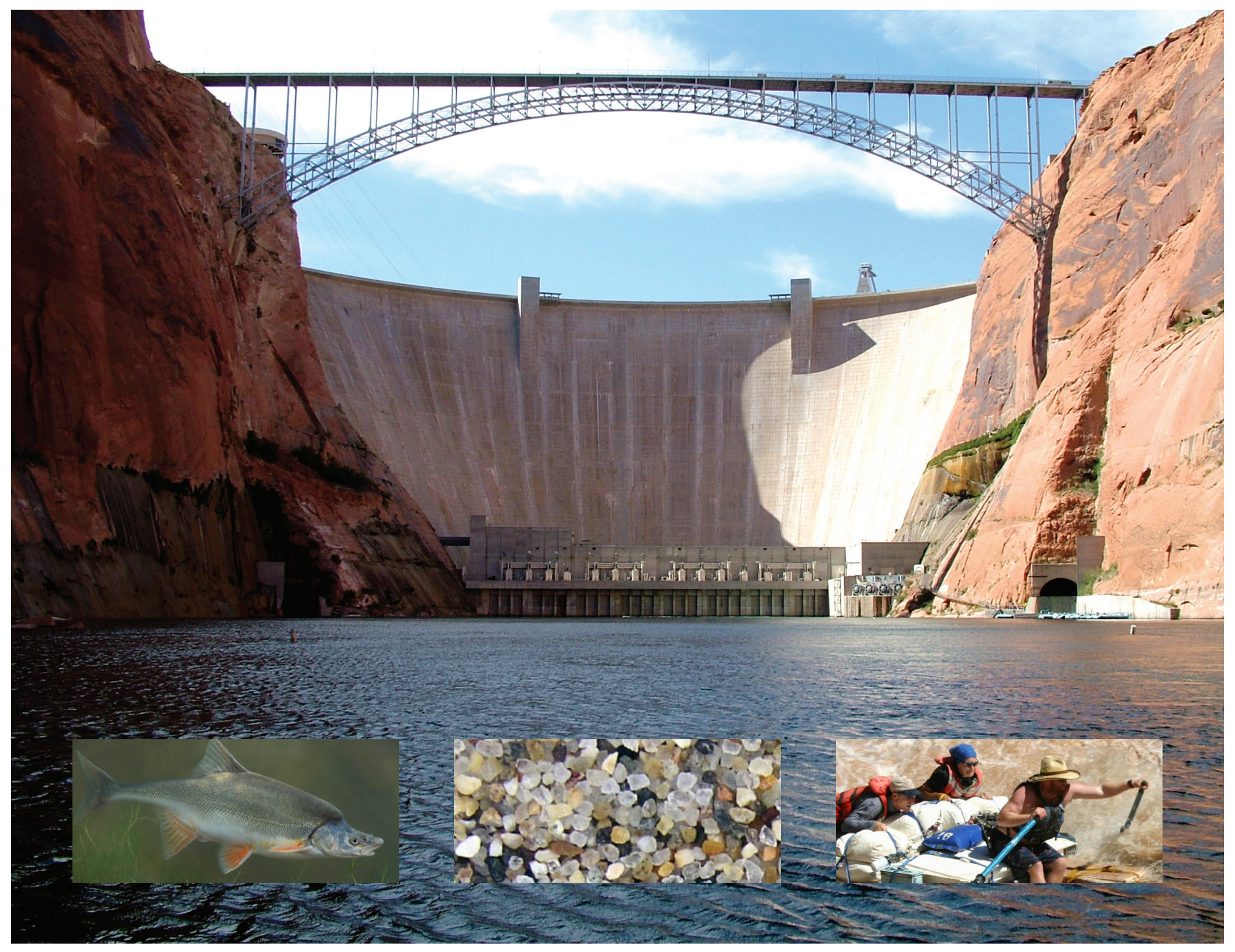

Open-File Report 2011-1220 
Cover photographs: Glen Canyon Dam, (C) 2004 Christopher E. Taesali, used with permission; humpback chub (Gila cypha), George Andrejko, Arizona Game and Fish Department; sand grains, David M. Rubin, U.S. Geological Survey; and whitewater raft, National Park Service. 


\section{Summary Report of Responses of Key Resources to the $\mathbf{2 0 0 0}$ Low Steady Summer Flow Experiment, along the Colorado River Downstream from Glen Canyon Dam, Arizona}

By Barbara E. Ralston

Open-File Report 2011-1220

U.S. Department of the Interior

U.S. Geological Survey 


\section{U.S. Department of the Interior \\ KEN SALAZAR, Secretary}

\section{U.S. Geological Survey \\ Marcia K. McNutt, Director}

U.S. Geological Survey, Reston, Virginia 2011

For product and ordering information:

World Wide Web: http://www.usgs.gov/pubprod

Telephone: 1-888-ASK-USGS

For more information on the USGS-the Federal source for science about the Earth, its natural and living resources, natural hazards, and the environment:

World Wide Web: http://www.usgs.gov

Telephone: 1-888-ASK-USGS

Suggested citation:

Ralston, B.E., 2011, Summary Report of Responses of Key Resources to the 2000 Low Steady Summer Flow Experiment, along the Colorado River Downstream from Glen Canyon Dam, Arizona: U.S. Geological Survey Open-File Report 2011-1220, 129 p.

Any use of trade, product, or firm names is for descriptive purposes only and does not imply endorsement by the U.S. Government.

Although this report is in the public domain, permission must be secured from the individual copyright owners to reproduce any copyrighted material contained within this report. 


\section{Contents}

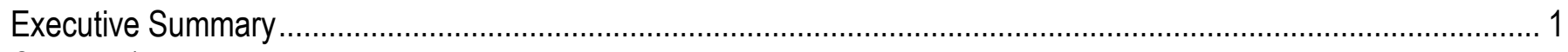

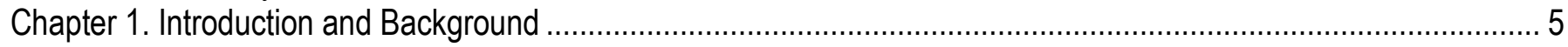

Chapter 2. Physical Resource Response to the Low Steady Summer Flow Experiment ......................................... 21

Chapter 3. Native and Nonnative Fish Response to the Steady Summer Flow Experiment in the Mainstem

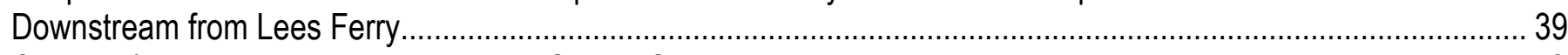

Chapter 4. Vegetation Response to Low Steady Summer Flow Experiment.......................................................... 53

Chapter 5. Effects of the Low Steady Summer Flow Experiment on Campsite Area, Rafting Safety and

Travel Time, and Overall Recreational Experience...

Chapter 6. Effect of the Low Steady Summer Flow Experiment on Angling Quality in the Lees Ferry

Trout Fishery

Chapter 7. Financial Costs Associated with the Low Summer Steady Flow Experiment

Chapter 8. Management Implications Associated with the Low Steady Summer Flow Experiment

Appendix. Annotated Bibliography of Studies Conducted During 2000 Low Steady Summer Flow Experiment 


\section{Conversion Factors}

Inch/Pound to SI

\begin{tabular}{|c|c|c|}
\hline Multiply & By & To obtain \\
\hline \multicolumn{3}{|c|}{ Length } \\
\hline mile (mi) & 1.609 & kilometer (km) \\
\hline \multicolumn{3}{|c|}{ Area } \\
\hline square foot $\left(\mathrm{ft}^{2}\right)$ & 0.09290 & square meter $\left(\mathrm{m}^{2}\right)$ \\
\hline square inch $\left(\right.$ in $\left.^{2}\right)$ & 6.452 & square centimeter $\left(\mathrm{cm}^{2}\right)$ \\
\hline \multicolumn{3}{|c|}{ Volume } \\
\hline cubic foot $\left(\mathrm{ft}^{3}\right)$ & 0.02832 & cubic meter $\left(\mathrm{m}^{3}\right)$ \\
\hline acre-foot (acre-ft) & 1,233 & cubic meter $\left(\mathrm{m}^{3}\right)$ \\
\hline \multicolumn{3}{|l|}{ SI to Inch/Pound } \\
\hline Multiply & By & To obtain \\
\hline \multicolumn{3}{|c|}{ Length } \\
\hline centimeter $(\mathrm{cm})$ & 0.3937 & inch (in.) \\
\hline millimeter (mm) & 0.03937 & inch (in.) \\
\hline meter $(\mathrm{m})$ & 3.281 & foot (ft) \\
\hline kilometer $(\mathrm{km})$ & 0.6214 & mile (mi) \\
\hline \multicolumn{3}{|c|}{ Area } \\
\hline square meter $\left(\mathrm{m}^{2}\right)$ & 10.76 & square foot $\left(\mathrm{ft}^{2}\right)$ \\
\hline square centimeter $\left(\mathrm{cm}^{2}\right)$ & 0.1550 & square inch $\left(\mathrm{ft}^{2}\right)$ \\
\hline \multicolumn{3}{|c|}{ Volume } \\
\hline cubic meter $\left(\mathrm{m}^{3}\right)$ & 35.31 & cubic foot $\left(\mathrm{ft}^{3}\right)$ \\
\hline cubic meter $\left(\mathrm{m}^{3}\right)$ & 0.0008107 & acre-foot (acre-ft) \\
\hline
\end{tabular}

Temperature in degrees Celsius $\left({ }^{\circ} \mathrm{C}\right)$ may be converted to degrees Fahrenheit $\left({ }^{\circ} \mathrm{F}\right)$ as follows:

${ }^{\circ} \mathrm{F}=\left(1.8 \times{ }^{\circ} \mathrm{C}\right)+32$

Temperature in degrees Fahrenheit $\left({ }^{\circ} \mathrm{F}\right)$ may be converted to degrees Celsius $\left({ }^{\circ} \mathrm{C}\right)$ as follows:

${ }^{\circ} \mathrm{C}=\left({ }^{\circ} \mathrm{F}-32\right) / 1.8$ 


\title{
Summary Report of Responses of Key Resources to the 2000 Low Steady Summer Flow Experiment, along the Colorado River Downstream from Glen Canyon Dam, Arizona
}

\author{
By Barbara E. Ralston
}

\section{Executive Summary}

In the spring and summer of 2000, a series of steady discharges of water from Glen Canyon Dam on the Colorado River were used to evaluate the effects of aquatic habitat stability and water temperatures on native fish growth and survival, with a special focus on the endangered humpback chub (Gila cypha), downstream from the dam in Grand Canyon. The steady releases were bracketed by peak powerplant releases in late-May and early-September. The duration and volume of releases from the dam varied between spring and summer. The intent of the experimental hydrograph was to mimic predam river discharge patterns by including a high, steady discharge in the spring and a low steady discharge in the summer. The hydrologic experiment was called the Low Steady Summer Flow (LSSF) experiment because steady discharges of $226 \mathrm{~m}^{3} / \mathrm{s}$ dominated the hydrograph for 4 months from June through September 2000 .

The experimental hydrograph was developed in response to one of the U.S. Fish and Wildlife Service's Reasonable and Prudent Alternatives (RPA) in its Biological Opinion of the Operation of Glen Canyon Dam Final Environmental Impact Statement. The RPA focused on the hypothesis that seasonally adjusted steady flows were dam operations that might benefit humpback chub more than the Record of Decision operations, known as Modified Low Fluctuating Flow (MLFF) operations. Condensed timelines between planning and implementation ( 2 months) of the experiment and the time required for logistics, purchasing, and contracting resulted in limited data collection during the high-release part of the experiment that occurred in spring. The LSSF experiment is the longest planned hydrograph that departed from the MLFF operations since Record of Decision operations began in 1996.

As part of the experiment, several studies focused on the responses of physical properties related to environments that young-of-year (YOY) native fish might occupy (for example, measuring mainstem and shoreline water temperature, and quantifying useable shorelines). The part of the hydrograph that included a habitat maintenance flow (a 4-day spike at a powerplant capacity of $877 \mathrm{~m}^{3} / \mathrm{s}$ ) and sustained high releases in April and May (averaging $509 \mathrm{~m}^{3} / \mathrm{s}$ ) resulted in sediment export to Lake Mead, the reservoir downstream from Glen Canyon Dam, which is outside the study area. Some mid-elevation sandbar building (between 566 and $877 \mathrm{~m}^{3} / \mathrm{s}$ stage elevations) occurred from existing sediment deposits rather than from sediment inputs from 
tributaries during the previous winter. Low releases in the summer combined with low tributary sediment inputs resulted in minor sediment accumulation in the study area. The September habitat maintenance flow reworked accumulated sediment and resulted in increases in the area of some backwaters. The mainstem water temperatures in the reach near the Little Colorado River during the LSSF experiment varied little from previous years. Mainstem water temperatures in western Grand Canyon average 17 to $20^{\circ} \mathrm{C}$. During the LSSF, backwaters warmed more than other shoreline environments during the day, but most backwaters returned to mainstem water temperatures overnight. Shoreline surface water temperatures from river mile (RM) 30 to 72 varied between 9 and $28^{\circ} \mathrm{C}$ in the middle of the day in July. These temperatures are within the optimal temperature range for humpback chub growth and spawning, which is between 15 and $24^{\circ} \mathrm{C}$. How surface water temperatures transfer to subsurface water temperatures is unknown.

Data collection associated with the response of fish to the 2000 LSSF hydrograph focused on fish growth and abundance along the Colorado River in Grand Canyon. The target resource, humpback chub and other native fishes, did not respond in a strongly positive or strongly negative manner to the LSSF hydrograph during the sampling period, which extended from June to September 2000. In 2000, the mean total length of YOY native fishes was similar to the mean length from previous years, but the abundance of YOY native fish was greater in 2000. The greatest numbers of humpback chub were near the confluence of the Colorado River with the Little Colorado River, where the largest spawning population is found. Factors directly associated with the LSSF hydrograph, geography, and the abundance of nonnative salmonids in the system before the experiment, as well as elements not affected by mainstem hydrology, may have contributed to the neutral response observed for native fish. The close proximity of the Little Colorado River to Glen Canyon Dam precluded sufficient warming of the mainstem down to the confluence with the Little Colorado River (RM 61) to reach optimal growth and spawning conditions for humpback chub, unlike shoreline surface water temperatures. The 4-day habitat maintenance flow in September interrupted persistent habitats for YOY fishes and may have confounded the results. The high abundance of salmonids in the mainstem before the experiment and predation by them may have affected the number and size of native fish that were caught. Native larval fish survival in the tributaries that is unrelated to mainstem environments and flow manipulations also can affect relative abundance observed in the mainstem. Collectively, these variables limit understanding the effects of the LSSF hydrograph on young native fish growth and survival.

The complicated hydrograph composed of steady discharges at multiple volumes that varied in duration from 4 days to 8 weeks and in magnitude from 226 to $877 \mathrm{~m}^{3} / \mathrm{s}$ presented a disruption to persistent habitat, which was the intent of the experiment. The longest uninterrupted period of persistent habitat for YOY fish was 3 months. YOY fish that entered the mainstem in mid-July (for example, humpback chub) had a shorter exposure to persistent habitat. Achieving effective high-magnitude discharges for ecological experiments is a challenge in a regulated system. The presence of a dam restricts discharge magnitude, and delivery agreements among States further restricts annual and monthly volumes releases.

A change in flow magnitude is the most common element associated with regulation, and fish appear to be sensitive to this variable. The spring discharge magnitudes during the LSSF experiment were only 25 percent greater than the average MLFFs in the 1990s and 78 percent less than the average predam spring discharge. The changes in discharge associated with the experimental hydrograph likely were too small compared to standard operations to observe a response by fish. The bulk of YOY fish enter the mainstem from tributaries in the summer 
months, with humpback chub YOY entering the mainstem primarily in association with monsoons that typically begin in July. Trying to affect life stages (for example, spawning and larval development) that primarily are associated with tributaries that have retained their hydrology by altering mainstem volumes may be minimally effective. Instead, developing experimental flows that can target YOY life stages directly affected by mainstem hydrology and temperatures may be more informative. In contrast to experiments involving large volume releases that can often only be of short-duration, lower volume releases may be more attainable and allow testing of hypotheses about limiting factors in endangered fish species survival in the mainstem.

Other resource responses that were measured during the LSSF experiment included seedling establishment of tamarisk (Tamarix spp.), growth of wetland species during the summer, recreation safety and perceptions, and the financial costs of the experimental hydrograph to recreational businesses and power users. The LSSF hydrograph supported tamarisk seedling establishment, as the high-sustained spring flows scoured shorelines and the habitat maintenance flow transported tamarisk seeds. The reduced summer hydrograph exposed open shorelines and resulted in a proliferation of tamarisk seedlings along the scoured shorelines. The September habitat maintenance flow reduced tamarisk seedling densities associated with later season germination; those individuals that first established in June likely persisted.

The experimental hydrograph affected recreational users and businesses, and the hydrograph increased the financial costs of power. The low-discharge part of the hydrograph, with reduced water velocity, increased travel time for whitewater rafting, reduced time spent at attraction sites, increased the availability of low-water camps, and initially increased the number of boating accidents at rapids. However, the recreational experience that includes these elements and participants' perceptions likely were affected little by the experimental hydrograph. Financial costs to the downstream commercial rafting industry included repair and replacement of equipment damaged by exposed rocks and customer refunds associated with trip evacuations because of stranding in rapids. Commercial fishing guides in Lees Ferry lost business during the habitat maintenance flows because they could not access desired fishing locales. Lastly, Federal power users incurred increased financial costs because the experiment occurred when higher than normal daily market prices had to be paid to supplement power needs. Reallocating water delivery to other months and in the subsequent water year (12 month delivery of water delivery from October to the end of September) to accommodate the hydrograph also increased costs to power users. The timing of the 2000 LSSF experiment was coincident with the onset of a drought in the American Southwest, an energy crisis in California, and market manipulation by energy suppliers that collectively affected daily market prices for power translated to increased costs to power users.

The 2000 LSSF experiment was the first seasonally based experiment using Glen Canyon Dam releases that focused on biological resources, primarily humpback chub and other native fish. Implementing such an ecosystem-scale experiment created an opportunity to learn about resource responses and identify flaws and barriers that limit experimental success. The short amount of time available for planning and implementation and the lack of long-term monitoring were apparent flaws of the 2000 LSSF experiment. Future experiments would benefit from sufficient planning, long-term monitoring, and testable hypotheses for resource responses that can be measured and are appropriate for the duration of the experiment. Future experiments would also benefit from publishing results and findings in peer-reviewed reports and journal articles that can be summarized for stakeholder use in a timely fashion. Reports by cooperators 
who collected and analyzed data are the first step in the process of incorporating knowledge but not the final step. Having citable literature, which can be incorporated into future experimental efforts, is critical to building a solid, peer-reviewed basis for documenting results and furthering experimental planning and decisionmaking by resource managers.

Basin hydrology and reservoir elevations greatly affect experimental capacity in the Colorado River downstream from Glen Canyon Dam. Taking advantage of unexpected sediment inputs to the system or increased water temperatures because of reduced inflows and associated reservoir elevations can be used to advance the understanding of how manipulated flow variables benefit downstream resources. If experiments were approached opportunistically, flexibility also would need to extend to administrative tasks associated with launch schedules, collection permits, and use of motorized equipment.

Experimental flexibility necessitates the implementation of long-term monitoring that provides a consistent data stream for long-term resource response. Immediate measures of response may be meaningless in the longer term, particularly for long-lived species, if consistent monitoring is absent after the experiment. A lack of response observed for 1 year may not mean the treatment was ineffective. Multiple years of data collection may be necessary for a response to be measurable or understood. 


\section{Chapter 1. Introduction and Background}

\section{Introduction}

Adaptive management acknowledges the inherent uncertainty of ecosystem responses to systemic management actions and embraces the notion of "learning by doing" (Walters and Holling, 1990). The U.S. Department of the Interior uses adaptive management approaches for several ecosystem-scale landscapes, including the Colorado River downstream from Glen Canyon Dam (fig. 1-1; Williams and others, 2007). The adaptive management program for Glen Canyon Dam, established in 1996 (U.S. Department of the Interior, 1996), was developed in response to the Operation of Glen Canyon Dam Final Environmental Impact Statement (GCDEIS; U.S. Department of the Interior, 1995) and the Grand Canyon Protection Act of 1992 (GCPA; title XVIII, secs. 1801-1809, of Public Law 102-575). The GCDEIS identified uncertainties of downstream resource responses to water release patterns from the dam. The GCPA directed the Secretary of the Interior to implement long-term monitoring programs and research activities to ensure that the dam was operated "in such a manner as to protect, mitigate adverse impacts to, and improve the values for which Grand Canyon National Park and Glen Canyon National Recreation Area were established, including, but not limited to natural and cultural resources and visitor use" (GCPA, sec. 1802(a)).

Short-duration, high-discharge floods from Glen Canyon Dam are the predominant ecosystem experiments implemented by the Secretary of the Interior since 1996 (U.S.

Department of the Interior, 1996; Melis, 2011). These floods (discharges as much as 1,274 cubic $\mathrm{m}^{3} / \mathrm{s}$ ) have advanced understanding about sediment storage and transport within the river corridor (Webb and others, 1999; Topping and others, 2000b; Rubin and others, 2002; Schmidt and others, 2004; Hazel and others, 2006; Wright and others, 2008). The responses of biological resources to these floods are not always immediately evident and may not be measurable depending on the life history of the organism and other factors, such as food availability and the effects that tributaries may have on the survival of organisms (Melis and others, 2006a; Coggins and Walters, 2009; Kennedy and Ralston, 2011).

A response to a multiple-day event by an organism does not necessarily identify the longterm fate of the population of the organism. Many investigators associated with an experimental flood conducted in 1996 noted immediate responses by fish or other organisms to the flood pulse. The responses were in the form of movement by fish or short-term reduction in algal and plant biomass through scour and transport (Kearsley and Ayers, 1999; McKinney and others, 1999; Stevens and others, 2001). For organisms that evolved in environments subject to annual flooding that lasted a month or more, the likelihood of a short-duration "flood" eliciting a longterm measurable biological response such as increased recruitment is low, and the reported results support this observation (Blinn and others, 1999; Kearsley and Ayers, 1999; McKinney and others, 1999). More recently, however, data from the 2008 high-flow experiment (HFE) suggest that rainbow trout in the Lees Ferry reach may have an increased recruitment response to these experiments (Korman and others, 2011). A longer-duration flow experiment intended to improve native fish growth and recruitment was implemented in the spring and summer of 2000. The experiment was called the Low Steady Summer Flow (LSSF) experiment. This report describes key results of the effects of the LSSF experiment on mainstem and shoreline water 
temperatures, sediment reworking and mainstem young-of-year (YOY) fish rearing environments, YOY fish growth and abundance, riparian vegetation response, campsite area and recreation satisfaction, and the financial costs of the experiment. Also included is a review of the process associated with the implementation of the experiment, a discussion of the management implications associated with long-duration experiments, and questions that remain unresolved following the LSSF experiment.

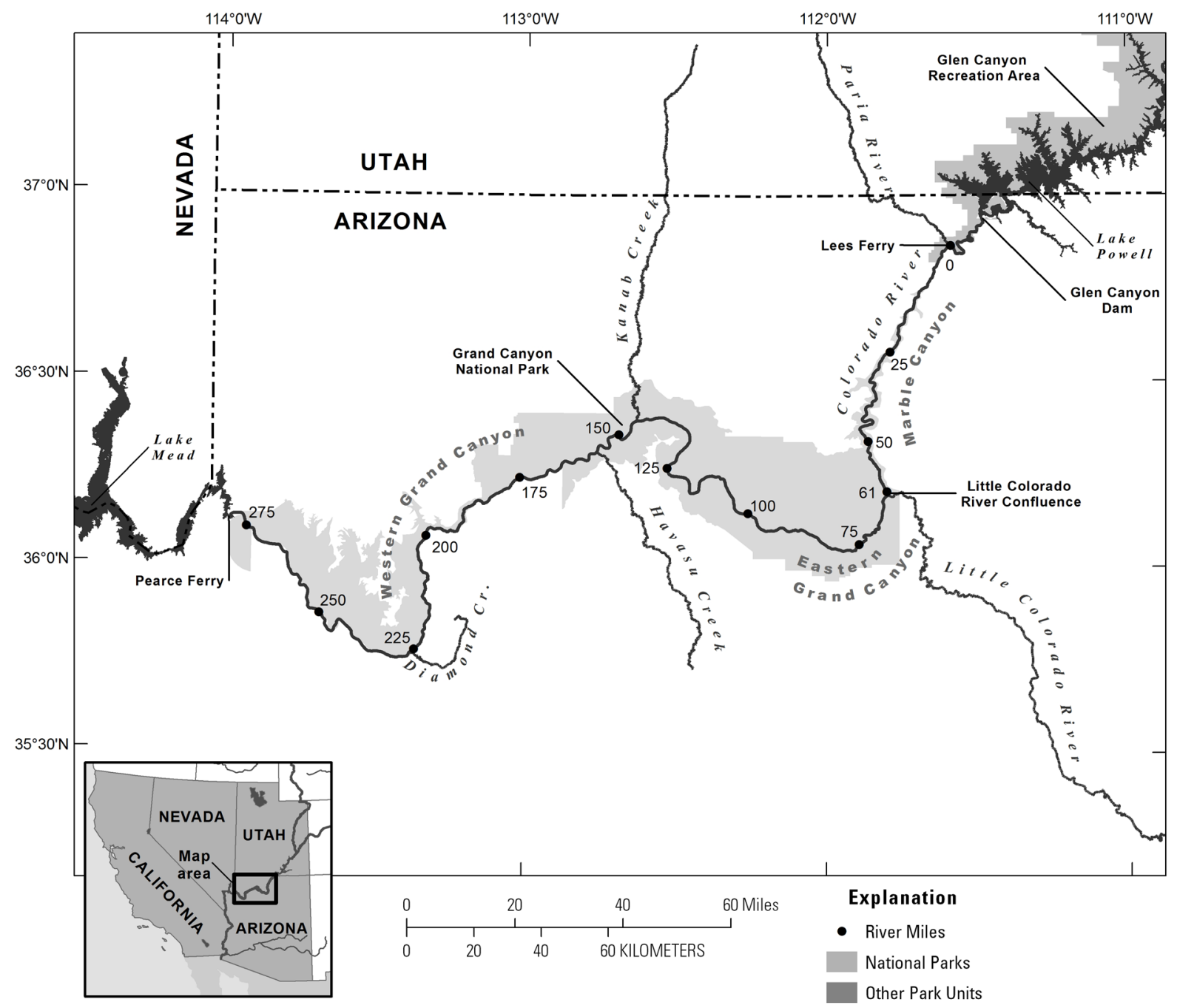

Figure 1-1. Map of the Colorado River downstream from Glen Canyon Dam. River mile (RM) designations occur at 25-mile intervals starting from Lees Ferry, designated as RM 0. Large tributaries to the mainstem, including the Little Colorado River, are identified. 


\section{Background}

Native fish species, particularly the endangered humpback chub (Gila cypha; fig. 1-2), are a resource of concern for the stakeholders in the Glen Canyon Dam Adaptive Management Program. The species' declining population numbers and their rarity were noted before the establishment of the Endangered Species Act (Minckley, 1991). Multiple factors contributed to the decline of the humpback chub, including predation by nonnative species, competition for resources, reduced mainstem temperatures (temperatures below $15^{\circ} \mathrm{C}$ ), and unstable shoreline habitats (Minckley, 1991; Gloss and Coggins, 2005; Yard and others, 2011). Aspects of Glen Canyon Dam operations that are hypothesized to affect native fish recruitment are coldwater dam releases that average $10.5^{\circ} \mathrm{C}$ (Vernieu and others, 2005; Voichick and Wright, 2007) and daily fluctuating discharges that result in unstable shoreline habitats. The result is reduced spawning, growth, and subsequent recruitment of humpback chub and other native fish species in the Colorado River mainstem downstream from Glen Canyon Dam (Hamman, 1982; Douglas and Marsh, 1996; Clarkson and Childs, 2000).

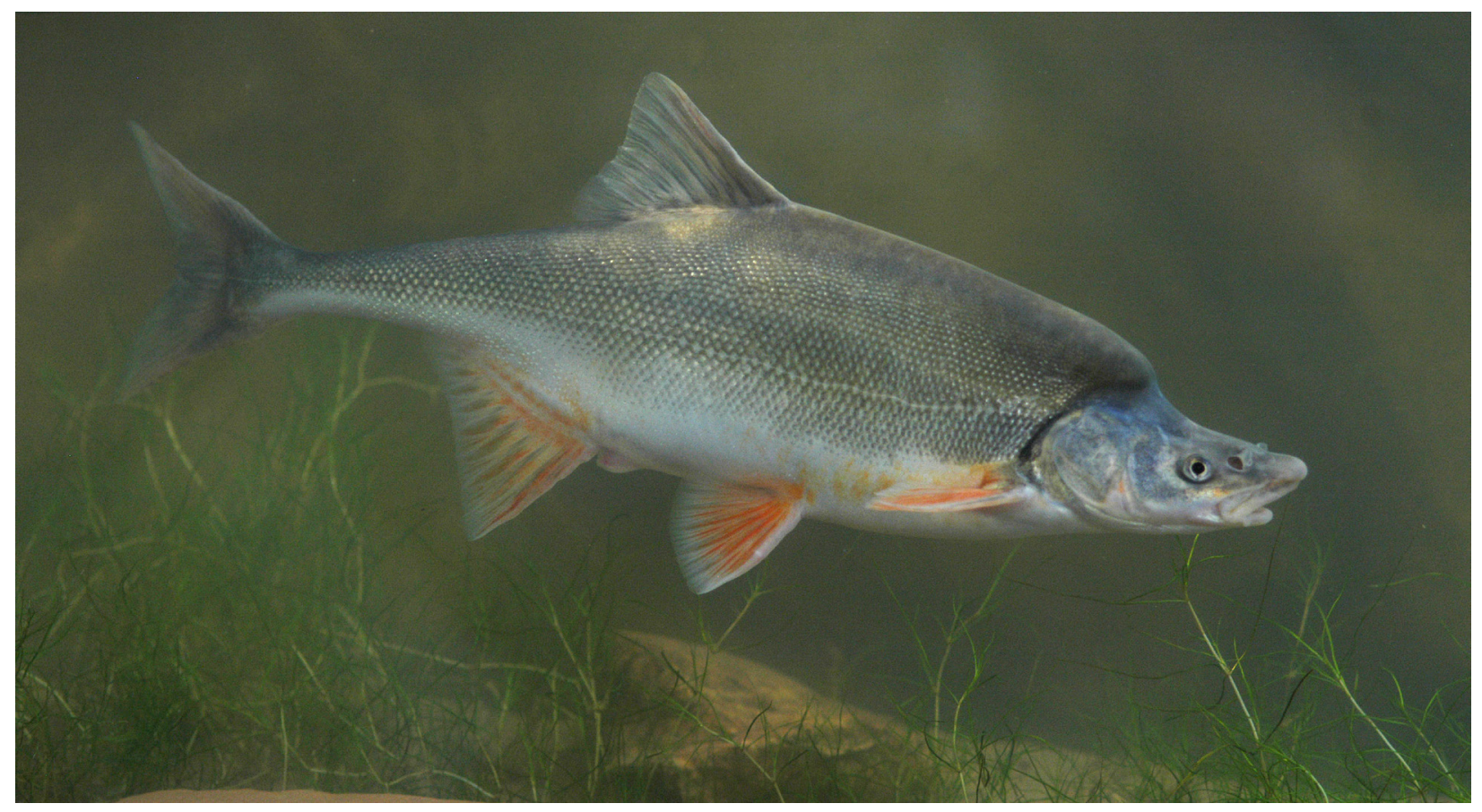

Figure 1-2. Image of adult humpback chub (Gila cypha), an endangered species with a population that persists in the Colorado River downstream from Glen Canyon Dam (George Andrejko, Arizona Game and Fish Department). Adult humpback chub range in size from 120 to $380 \mathrm{~mm}$ (Marsh and Douglas, 1997).

The U.S. Fish and Wildlife Service issued a Biological Opinion (U.S. Fish and Wildlife Service, 1995) and a series of Reasonable Prudent Alternatives (RPAs) in association with the GCDEIS to improve conditions for endangered native fish, principally humpback chub. One RPA directed the Bureau of Reclamation to initiate a program of experimental dam releases consisting of high, steady flows in the spring and low steady flows in the summer. The experimental flows were to be implemented when annual water delivery between the upper and 
lower Colorado River Basin States (not shown) was at the minimum of 8.23 million acre feet (maf). The assumptions of the required flows were that long-duration, steady flows would reduce the risk of further jeopardizing the continued existence of the endangered humpback chub by stabilizing shoreline habitats for young humpback chub, and that mainstem temperatures would increase in association with low-volume, steady releases, thus improving spawning and growth of this species in the mainstem (U.S. Fish and Wildlife Service, 1995).

In response to the RPA, a flow plan that considered habitat needs associated with humpback chub life-history stages (for example, larvae, YOY, juveniles) and other native fish was developed by SWCA Environmental Consultants, Inc. (Valdez and others, unpub. report, $2000^{1}$ ). Valdez and others (unpub. report, 2000) recommended different discharges and release patterns for each life stage and divided flows into three time periods: March-May (high steady flows of $594 \mathrm{~m}^{3} / \mathrm{s}$ with a 4-day $877 \mathrm{~m}^{3} / \mathrm{s}$ spike); June-September (low steady flows of $226 \mathrm{~m}^{3} / \mathrm{s}$ ending with a 4-day $877 \mathrm{~m}^{3} / \mathrm{s}$ spike); and October-February (steady flows of $226 \mathrm{~m}^{3} / \mathrm{s}$ ). The three time-periods (fig. 1-3) are respectively coincident with spawning and emergence in tributaries, summer migration into the mainstem and subsequent growth, and overwintering in the mainstem. Valdez and others (unpub. report, 2000) identified the following objectives for experimental flow plan:

- To enhance survival and growth of young native fishes by providing stable, warm, productive shoreline nursery habitats

- To increase recruitment of native fish

- To minimize adverse effects of nonnative fish

- To contribute to the recovery of endangered humpback chub

\footnotetext{
${ }^{1}$ Although the U.S. Geological Survey does not typically cite unpublished reports, this report makes reference to several unpublished reports to provide the reader with important background information not otherwise available. Copies of unpublished reports are available upon request by contacting the Center Director, U.S. Geological Survey, Southwest Biological Science Center, 2255 N. Gemini Drive, Flagstaff, Ariz. 86001.
} 


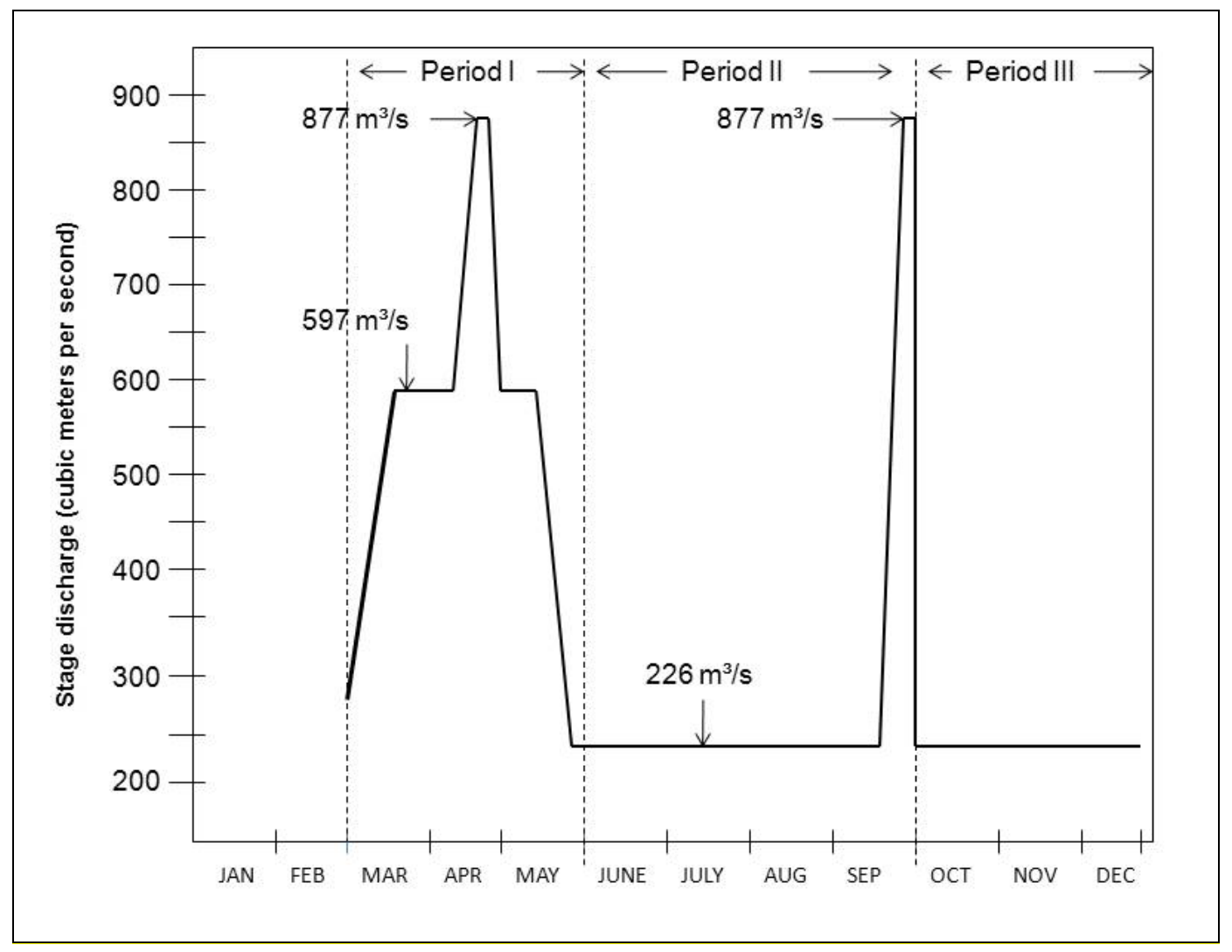

Figure 1-3. Experimental hydrograph of dam releases measured in cubic meters per second $\left(\mathrm{m}^{3} / \mathrm{s}\right)$ from Glen Canyon Dam recommended by Valdez and others (adapted from Valdez and others, unpub. report, 2000).

Valdez and others (unpub. report, 2000) identified the objective of each flow period and the potential response by physical and aquatic resources (table 1-1). They identified possible negative and positive effects to sediment because sediment conservation is affected directly by discharge volume, and sediment in eddies affects some fish habitat (for example, backwaters). The plan did not speculate on the effects of the hydrograph on resources that did not appear to support fish directly (for example, riparian vegetation and recreation). Funding was provided by the Bureau of Reclamation to study the response of these resources as well as those identified by Valdez and others (unpub. report, 2000). 
Table 1-1. Hypothesized effects of experimental flows on physical and aquatic resources (Valdez and others, unpub. report, 2000), and identification of associated studies conducted during the 2000 Low Steady Summer Flow (LSSF) experiment.

\begin{tabular}{|c|c|c|}
\hline $\begin{array}{c}\text { Benefits to physical and aquatic } \\
\text { resources }\end{array}$ & $\begin{array}{l}\text { Risks to physical and aquatic } \\
\text { resources }\end{array}$ & $\begin{array}{l}\text { Studied during LSSFI } \\
\text { author }\end{array}$ \\
\hline \multicolumn{3}{|c|}{ Period 1: March to May } \\
\hline $\begin{array}{l}\text { Scour backwater eddies and } \\
\text { increase area for shoreline fish } \\
\text { habitat }\end{array}$ & No negative risk identified & $\begin{array}{l}\text { YES } \\
\text { Goeking and others, unpub. report, } \\
\text { 2003; Hazel and others, 2006; } \\
\text { Schmidt and others, } 2007 .\end{array}$ \\
\hline $\begin{array}{l}\text { Mobilize and store sand and } \\
\text { sediment in campsites/increase } \\
\text { campsite area }\end{array}$ & $\begin{array}{l}\text { Export sediment, reduce campsite } \\
\text { areas }\end{array}$ & $\begin{array}{l}\text { YES } \\
\text { Hazel and others, 2006; Schmidt } \\
\text { and others, } 2007 .\end{array}$ \\
\hline $\begin{array}{l}\text { Create warm, low-velocity areas at } \\
\text { tributary mouths }\end{array}$ & No negative risk identified & $\begin{array}{l}\text { YES } \\
\text { Protiva and others, } 2010\end{array}$ \\
\hline $\begin{array}{l}\text { Ponding as thermal refuges for } \\
\text { drifting larvae and young fish }\end{array}$ & $\begin{array}{l}\text { Warm ponded tributaries attract } \\
\text { nonnative fish predators/ } \\
\text { competitors }\end{array}$ & NO \\
\hline $\begin{array}{l}\text { Destabilize habitats to } \\
\text { disadvantage nonnative fishes }\end{array}$ & No negative risk identified & NO \\
\hline Redistribute nutrients & No negative risk identified & NO \\
\hline $\begin{array}{l}\text { Reset community primary } \\
\text { production }\end{array}$ & No negative risk identified & NO \\
\hline $\begin{array}{l}\text { Spike flows flush nonnative fish } \\
\text { from nearshore habitats }\end{array}$ & No negative risk identified & NO \\
\hline \multicolumn{3}{|c|}{ Period II: June to September } \\
\hline Store sediment in river channel & No negative risk identified & $\begin{array}{l}\text { Hazel and others, 2006; Schmidt } \\
\text { and others, } 2007 .\end{array}$ \\
\hline Expand campsite beach area & No negative risk identified & $\begin{array}{l}\text { YES } \\
\text { Kaplinski and others, 2005; Hazel } \\
\text { and others, 2006; Schmidt and } \\
\text { others, } 2007 .\end{array}$ \\
\hline $\begin{array}{l}\text { September habitat maintenance } \\
\text { flows resuspend and store sand } \\
\text { from summer tributary inputs }\end{array}$ & $\begin{array}{l}\text { September habitat maintenance } \\
\text { flows export sand and sediment } \\
\text { instead of storing it }\end{array}$ & $\begin{array}{l}\text { YES } \\
\text { Kaplinski and others, 2005; Hazel } \\
\text { and others, 2006; Schmidt and } \\
\text { others, } 2007 .\end{array}$ \\
\hline $\begin{array}{l}\text { Create stable shorelines for fish } \\
\text { habitat }\end{array}$ & No negative risk identified & $\begin{array}{l}\text { YES } \\
\text { Korman and others, } 2004\end{array}$ \\
\hline $\begin{array}{l}\text { Increased growth and survival of } \\
\text { young native fishes }\end{array}$ & $\begin{array}{l}\text { Increased growth and survival of } \\
\text { nonnative fishes }\end{array}$ & $\begin{array}{l}\text { YES } \\
\text { Trammell and others, unpub. } \\
\text { report, 2002; Speas and others, } \\
\text { unpub. report, 2003, 2004; } \\
\text { Coggins and Walters, } 2009\end{array}$ \\
\hline $\begin{array}{l}\text { Increased autotrophic algal and } \\
\text { macroinvertebrate production }\end{array}$ & Decreased drift of food for fish & $\begin{array}{l}\text { YES } \\
\text { Yard and Blinn unpub. report, } \\
\text { 2001; Rogers and others, unpub. } \\
\text { report, 2003;Benenati and others, } \\
\text { unpub. report, } 2002\end{array}$ \\
\hline
\end{tabular}


Table 1-1. Hypothesized effects of experimental flows on physical and aquatic resources (Valdez and others, unpub. report, 2000), and identification of associated studies conducted during the 2000 Low Steady Summer Flow (LSSF) experiment. - Continued

\begin{tabular}{|c|c|c|}
\hline $\begin{array}{c}\text { Benefits to physical and aquatic } \\
\text { resources }\end{array}$ & $\begin{array}{l}\text { Risks to physical and aquatic } \\
\text { resources }\end{array}$ & $\begin{array}{l}\text { Studied during LSSFI } \\
\text { author }\end{array}$ \\
\hline $\begin{array}{l}\text { Possible mainstem hatching } \\
\text { success }\end{array}$ & $\begin{array}{l}\text { Mainstem reproduction by } \\
\text { nonnative fishes }\end{array}$ & $\begin{array}{l}\text { YES } \\
\text { Trammell and others, unpub. } \\
\text { report, } 2002\end{array}$ \\
\hline $\begin{array}{l}\text { September habitat maintenance } \\
\text { flows flush nonnative fishes from } \\
\text { nearshore habitats }\end{array}$ & $\begin{array}{l}\text { Minimized thermal plume at RM } \\
30 \text { may reduce survival of young } \\
\text { humpback chub }\end{array}$ & NO \\
\hline $\begin{array}{l}\text { September habitat maintenance } \\
\text { flows flush nonnative fishes from } \\
\text { nearshore habitats }\end{array}$ & $\begin{array}{l}\text { Increased water clarity leads to } \\
\text { increased predation of native fish } \\
\text { by sight predators }\end{array}$ & NO \\
\hline $\begin{array}{l}\text { September habitat maintenance } \\
\text { flows flush nonnative fishes from } \\
\text { nearshore habitats }\end{array}$ & $\begin{array}{l}\text { Increased infestation of parasites } \\
\text { and diseases }\end{array}$ & NO \\
\hline \multicolumn{3}{|c|}{ Period III: October to February } \\
\hline $\begin{array}{l}\text { Retain sediment with low volume } \\
\text { discharge }\end{array}$ & No negative risk identified & $\mathrm{NO}$ \\
\hline $\begin{array}{l}\text { Increased survival of young native } \\
\text { fishes }\end{array}$ & $\begin{array}{l}\text { Possible overwinter survival and } \\
\text { expansion of nonnative fishes }\end{array}$ & $\begin{array}{l}\text { YES } \\
\text { Trammell and others, unpub. } \\
\text { report, 2002; Speas and others, } \\
\text { unpub. report, 2004. Modified } \\
\text { Low Fluctuating Flow operations } \\
\text { implemented in October } 2000 \text { and } \\
\text { overwinter survival under steady } \\
\text { flows not tested }\end{array}$ \\
\hline $\begin{array}{l}\text { Maintain stable winter conditions } \\
\text { to minimize energy expenditure }\end{array}$ & $\begin{array}{l}\text { Possible greater spawning success } \\
\text { of downstream populations of } \\
\text { trout }\end{array}$ & NO \\
\hline $\begin{array}{l}\text { Maintain overwinter autotrophic } \\
\text { production in mainstem, } \\
\text { shorelines, backwaters }\end{array}$ & Decreased drift of food for fish & NO \\
\hline $\begin{array}{l}\text { Maintain overwinter autotrophic } \\
\text { production in mainstem, } \\
\text { shorelines, backwaters }\end{array}$ & $\begin{array}{l}\text { Increased predation by sight } \\
\text { feeders }\end{array}$ & $\begin{array}{l}\text { NO } \\
\text { Modified Low Fluctuating Flow } \\
\text { operations implemented in } \\
\text { October } 2000 \text { and studies } \\
\text { discontinued }\end{array}$ \\
\hline
\end{tabular}

The experimental plan (Valdez and others, unpub. report, 2000) recommended that longterm monitoring of resources be in place for trend detection before experimentation. They also suggested data collection should occur for a year of Modified Low Fluctuating Flow (MLFF) operations for an 8.23 maf water year (WY; water delivery for 12 months from October to the end of September) before implementing the experimental LSSF hydrograph. Additionally, the authors outlined a yearlong implementation process for the experiment that included stakeholder approval, regulatory environmental assessment and permitting, and data collection and reporting. Before the LSSF experimental hydrographic planning document was finalized (Valdez and others, unpub. report, 2000), discussions began among the Bureau of Reclamation, Grand Canyon Monitoring and Research Center (GCMRC), and other U.S. Department of the Interior 
partners in January 2000 about implementing the LSSF experimental hydrograph in April 2000. As a result, the LSSF experiment proceeded without the recommended year of baseline monitoring under MLFF operations in an 8.23-maf WY.

\section{Plan Implementation and Data Collection Limitations}

The precipitation and snowpack conditions in the upper Colorado River Basin (not shown) and the desire to meet Biological Opinion requirements associated with the GCDEIS converged in the winter of 2000. The convergence resulted in a compressed timeline for the implementation of an LSSF experiment in 2000. In January 2000, the Bureau of Reclamation identified a high likelihood that the 2000 WY (October 1999-September 2000) would be an 8.23 maf delivery year and that an LSSF experiment might be implemented. The Bureau of Reclamation identified March 2000 as the time at which a final decision about implementing the LSSF experiment would take place, because by that time more data would be available about the snowpack and predicted inflows to Lake Powell, the reservoir formed by Glen Canyon Dam (fig. 1-1). The experimental flow plan by Valdez and others (unpub. report, 2000) provided a hydrograph (fig. 4), but lacked specific field approaches to evaluate resource responses to the experimental hydrograph. There was no consistent monitoring plan in place for many of the downstream resources in 2000; instead, several resource programs were initiating reviews of previous data-collection efforts for implementing long-term monitoring. In early February 2000, GCMRC convened a meeting of existing cooperators to explain the experimental hydrograph and identify potential projects, approaches, and logistics needs for the LSSF experiment. In March 2000, the Bureau of Reclamation determined that an LSSF experiment would proceed. The decision in March 2000 to implement the LSSF experiment provided some investigators, Grand Canyon National Park (GRCA), GCMRC, and the Bureau of Reclamation 1 month to prepare for and implement the experiment. Work associated with implementation included identifying logistics needs, securing necessary permits, modifying and establishing new agreements among cooperators, and buying equipment. Some of the hypotheses and data-collection approaches identified in the plan (Valdez and others, unpub. report, 2000; table 1-1) could not be addressed because of the compressed timeline for planning and implementation. For example, no baseline data were collected during a year of MLFF operations with an annual release of less than or equal to 8.23 maf.

The hydrograph implemented during the 2000 LSSF experiment differed from the hydrograph proposed by Valdez and others (unpub. report, 2000). The high, steady discharge in spring was reduced to $481 \mathrm{~m}^{3} / \mathrm{s}$ in volume and shortened in duration by a month, starting in April rather than March (fig. 1-4). The reduction in the volume and duration of the hydrograph compromised the ponding hypotheses associated with Period I (table 1-1); although, the velocity and temperatures at tributary mouths could be measured under different discharge volumes, the duration of ponding and its effects on larval retention could not be measured as originally intended. The proposed fall steady flows were terminated and MLFF operations were resumed on October 1, 2000 (fig. 1-4). As a result, the effects of stable shorelines on growth and survival of juvenile and YOY native fish in the fall period were not measured. Instead of developing alternative hypotheses associated with the return of MLFF operations and young fish survival or other resource responses, data collection for most resources ended when MLFF operations resumed. With respect to environmental compliance needs, an environmental assessment of the experiment was unnecessary because the hydrograph did not exceed powerplant capacity and fell within Record of Decision flow criteria. As a result, implementation proceeded quickly. 


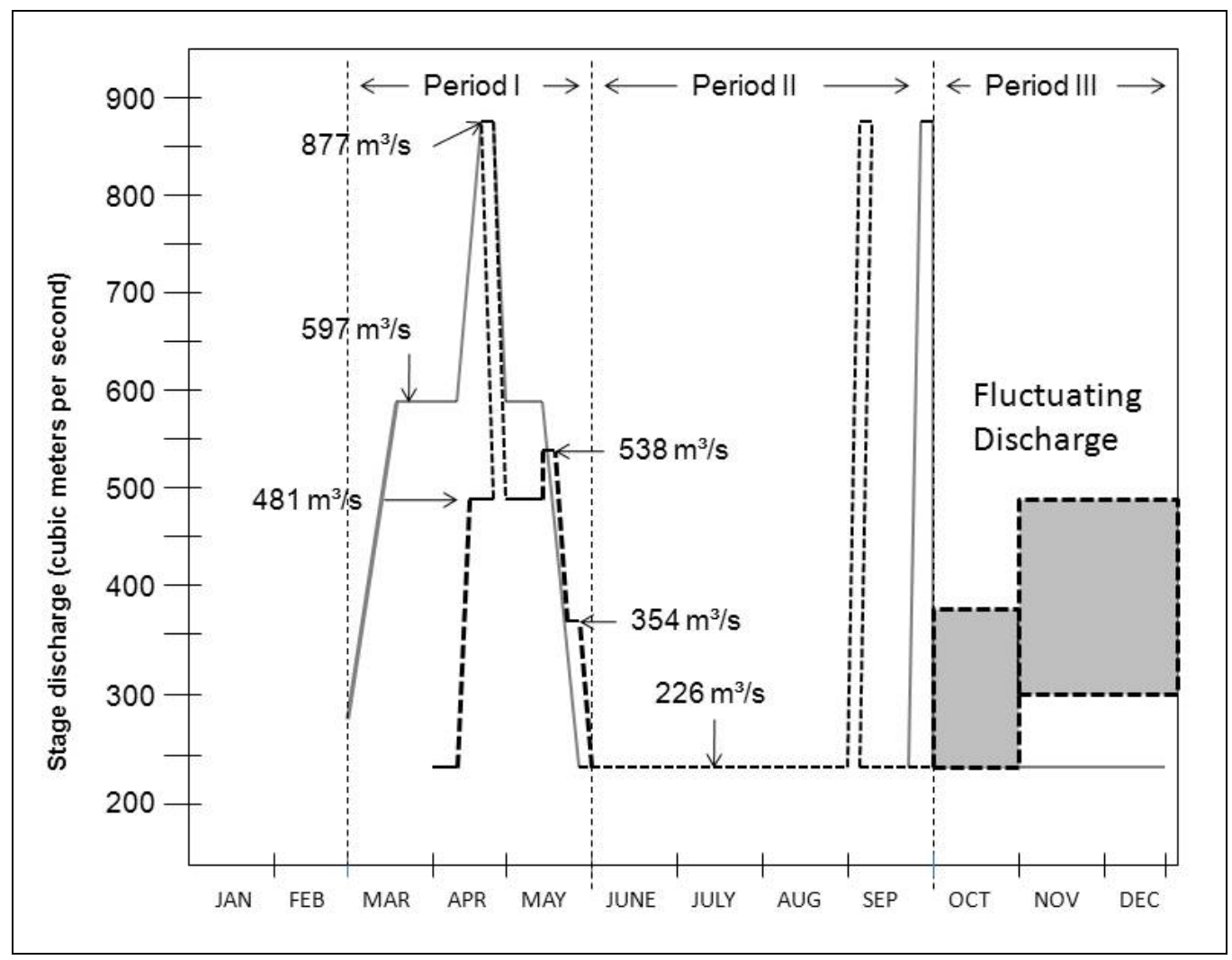

Figure 1-4. Actual release pattern of the experimental flow period from March to October 2000 (dotted line) compared with the proposed experimental hydrograph (solid line) from Valdez and others (unpub. report, 2000).

LSSF research projects dealt with individual resources and addressed questions related to separate periods of the LSSF hydrograph. Physical, biological, and cultural resources were studied, including sediment transport and reworking, changes in water temperature, aquatic productivity, mainstem fish growth and abundance, riparian vegetation response, recreation safety and perceptions, and the financial costs of the experiment. Many of the LSSF projects were expanded efforts of existing research projects. For example, the sandbar and sediment mass-balance project scheduled to collect sandbar area and volume data in the summer of 2000 expanded the number of trips and data-collection efforts to capture information about sediment response for each experimental flow period (Schmidt and others, 2007). Some projects only collected data during a single period within the experiment. For example, an algal production study only occurred during Period II (Yard and Blinn, unpub. report, 2001). Other projects collected data for a 2-year period, as in the case of riparian vegetation (Porter, 2002), or for a 9year period following the experiment, as in the case of humpback chub population estimates (Coggins and Walters, 2009).

The status of monitoring program development for resources along the Colorado River affected data collection approaches, intensity, and the ability of researchers to draw conclusions about experimental effects. Plans for long-term monitoring of resources for Record of Decision operations were still in development in 2000 (U.S. Geological Survey, 1999; Urquhart and others, unpub. report, 2000; Anders and others, unpub. report, 2001). A comprehensive longterm dataset for resources responding to different hydrographs was not available, which limited 
researchers' abilities to compare resource responses to the LSSF hydrograph with Record of Decision operations. However, the LSSF experiment provided opportunities to test sampling strategies for long-term monitoring (Schmidt and others, 2007) because steady flow operations removed one variable that can affect sampling for fish and sediment resources. In 2000, a fishmonitoring program that estimated fish abundance downstream from Glen Canyon Dam was not well developed. The fisheries and physical science programs used the experiment to refine sampling approaches. As of this writing (2011), long-term monitoring programs for resources remain in various states of development.

\section{Report Organization, Place Names, and Units}

This report summarizes the hydrologic design and implementation of the LSSF experiment and describes the response of the key resources that were monitored during the experiment. A conceptual diagram (fig. 1-5) developed for this report identifies the relations of resources that were studied during the LSSF experiment. This report includes an annotated bibliography summarizing individual publications associated with the LSSF experiment (appendix). The final section of this report identifies the successes and failures of the LSSF experiment and identifies aspects of resource responses to the experimental hydrograph that remain unknown.

Throughout the report, "Grand Canyon" is used broadly to refer to the Colorado River corridor between Glen Canyon Dam and the western boundary of Grand Canyon National Park, including Glen, Marble, and Grand Canyons. The study area is referred to as the "Colorado River ecosystem" (CRE).

In this report, metric units are used for all units, with the exception of river miles. By convention, locations along the Colorado River below Glen Canyon are identified by river mile (RM) and by side of the river (left (L) or right (R)). Lees Ferry, which is the dividing point between the upper and lower Colorado River Basin, is the starting point RM 0 (fig. 1-1), with mileage measured in upstream (-) and downstream directions. 


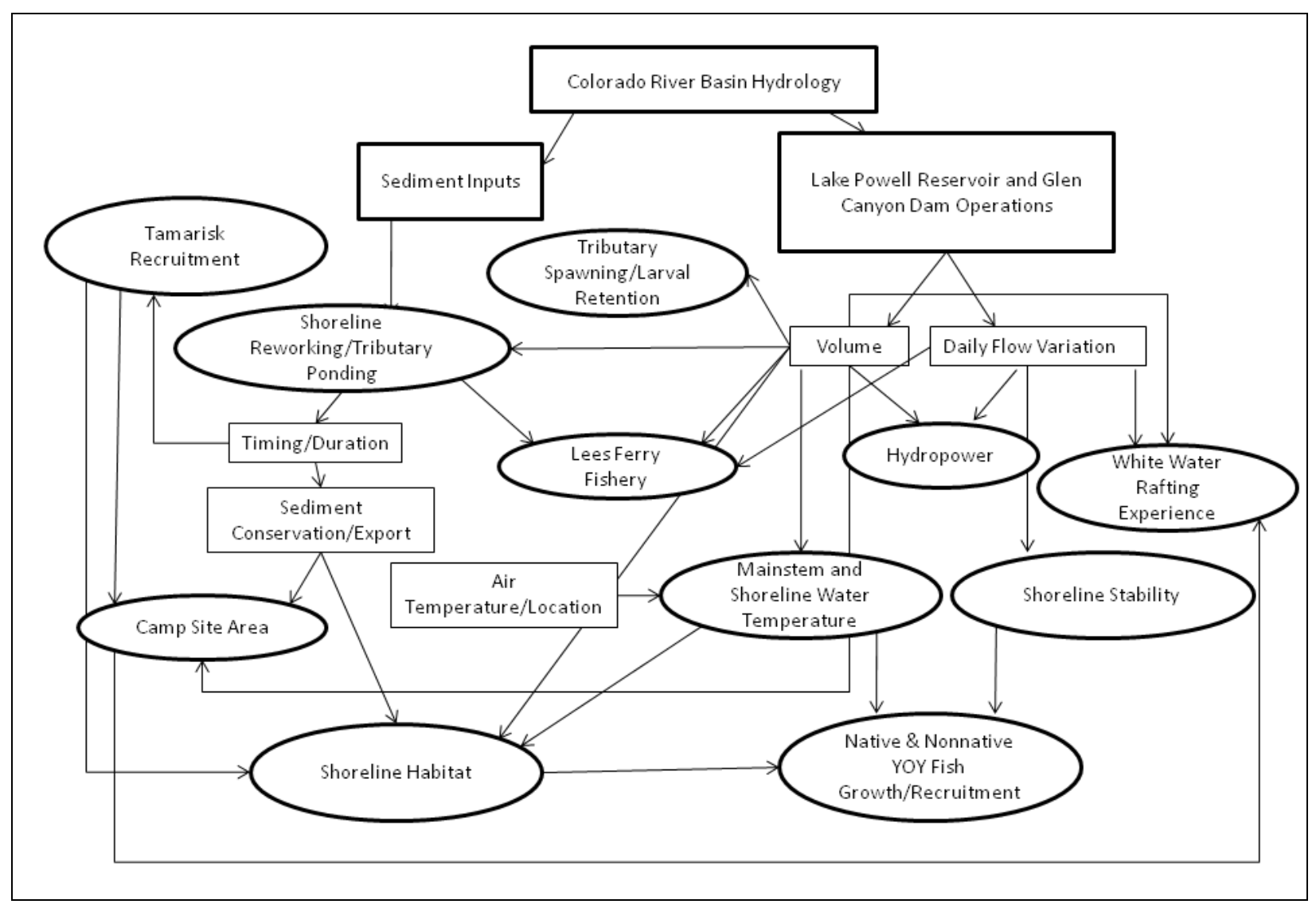

Figure 1-5. Diagram of the resources studied during the Low Steady Summer Flow Experiment (ovals) and variables that affect the resource response (squares) with arrows identifying connections between resources and variables.

\section{Acknowledgments}

This report was funded by hydropower revenues provided by the Bureau of Reclamation as part of the Glen Canyon Dam Adaptive Management Program (GCDAMP). The GCDAMP was established in 1997 to provide for long-term research and monitoring of downstream resources affected by Glen Canyon Dam. Scientific information such as that contained in this report, is used as the basis for developing recommendations for dam operations and management actions. More information on the GCDAMP is available at http://www.gcdamp.gov/.

Several people provided input on this document and greatly improved the quality and readability of this document. They are, in no particular order, Scott Wright, Theodore Kennedy, Mike Yard, Matthew Andersen, John Hamill, Marjike van Heeswijk, and two anonymous reviewers. Special thanks go to Ronald Kirby, Lara Schmit, and Meredith Hartwell for their dedication and commitment to excellence, which improved the quality and readability of this document.

\section{References}

Anders, P., Bradford, M., Higgins, P.S., Nislow, K.H., Rabeni, C., and Tate, C., 2001, Final report of the Aquatic Protocol Evaluation Program Panel: U.S. Geological Survey, Grand 
Canyon Monitoring and Research Center, 43 p. [Available upon request by contacting the Center Director, U.S. Geological Survey, Southwest Biological Science Center, 2255 N. Gemini Drive, Flagstaff, Ariz. 86001.]

Benenati, E.P., Shannon, J.P., Haden, G.A., Straka, K., and Blinn, D.W., 2002, Monitoring and research - the aquatic food base in the Colorado River, Arizona during 1991-2001—final report: Flagstaff, Arizona Game and Fish, U.S. Fish and Wildlife Service and Northern Arizona University, submitted to U.S. Geological Survey, Grand Canyon Monitoring and Research Center, cooperative agreement no. 1452-98-FC-225590, 227 p. [Available upon request by contacting the Center Director, U.S. Geological Survey, Southwest Biological Science Center, 2255 N. Gemini Drive, Flagstaff, Ariz. 86001.]

Blinn, D.W., Shannon, J.P., Wilson, K.P., O'Brien, C., and Benenati, P.L., 1999, Response of benthos and organic drift to a controlled flood, in Webb, R.H., Schmidt, J.C., Marzolf, G.R., and Valdez, R.A., eds., The controlled flood in Grand Canyon, v. 110: Washington, D.C., American Geophysical Union, Geophysical Monograph Series, p. 259-272.

Clarkson, R.W., and Childs, M.R., 2000, Temperature effects of hypolimnial-release dams on early life stages of Colorado River Basin big-river fishes: Copeia, v. 2000, no. 2, p. 402-412, accessed on August 19, 2011 at http://www.bioone.org/doi/abs/10.1643/00458511(2000)000\%5B0402\%3ATEOHRD\%5D2.0.CO\%3B2.

Coggins, L.G., Jr., and Walters, C.J., 2009, Abundance trends and status of the Little Colorado River population of humpback chub — an update considering data from 1989-2008: U.S. Geological Survey Open-File Report 2009-1075, 18 p., accessed on August 2, 2011, at http://pubs.usgs.gov/of/2009/1075/.

Douglas, M.E., and Marsh, P.C., 1996, Population estimates/population movements of Gila cypha, an endangered cyprinid fish in the Grand Canyon region of Arizona: Copeia, v. 1996, no. 1, p. 15-28, accessed on February 10, 2010, at http://www.jstor.org/stable/pdfplus/1446938.pdf.

Gloss, S.P., and Coggins, L.C., Jr., 2005, Fishes of Grand Canyon, in Gloss, S.P., Lovich, J.E., and Melis, T.S., eds., The state of the Colorado River ecosystem in Grand Canyon: U.S. Geological Survey Circular 1282, 33-56 p., accessed on May 10, 2010, at http://pubs.usgs.gov/circ/1282/.

Goeking, S.A., Schmidt, J.C., and Webb, M.K., 2003, Spatial and temporal trends in the size and number of backwaters between 1935 and 2000, Marble and Grand Canyons, Arizonafinal report: U.S. Geological Survey, Grand Canyon Monitoring and Research Center and Utah State University, Department of Aquatic, Watershed and Earth Resources, cooperative agreement no. 01WRAG0059, 26 p. [Available upon request by contacting the Center Director, U.S. Geological Survey, Southwest Biological Science Center, 2255 N. Gemini Drive, Flagstaff, Ariz. 86001.]

Hamman, R.L., 1982, Spawning and culture of humpback chub: The Progressive Fish-Culturist, v. 44, no. 4, p. 213-216, accessed on December 1, 2010, at http://afsjournals.org/doi/abs/10.1577/15488659(1982)44\%5B213:SACOHC\%5D2.0.CO\%3B2.

Hazel, J.E., Jr., Topping, D.J., Schmidt, J.C., and Kaplinski, M., 2006, Influence of a dam on fine-sediment storage in a canyon river: Journal of Geophysical Research, v. 111, no. F01025, doi: 10.1029/2004JF000193, p. 1-16, accessed on December 28, 2009, at http://www.agu.org/journals/jf/jf0601/2004JF000193/2004JF000193.pdf.

Kaplinski, M., Hazel, J.E., and Parnell, R., 2005, Campsite area monitoring in the Colorado River ecosystem-1998-2003 - final report: Flagstaff, Northern Arizona University, 
Department of Geology, submitted to U.S. Geological Survey, Grand Canyon Monitoring and Research Center, mod. no. 5 1425-98-FC-40-22630, 39 p.

Kearsley, M.J.C., and Ayers, T.J., 1999, Riparian vegetation responses - snatching defeat from the jaws of victory and vice versa, in Webb, R.H., Schmidt, J.C., Marzolf, G.R., and Valdez, R.A., eds., The controlled flood in Grand Canyon, v. 110: Washington, D.C., American Geophysical Union, Geophysical Monograph Series, p. 309-327.

Kennedy, T.A., and Ralston, B.E., 2011, Biological responses to high-flow experiments at Glen Canyon Dam, in Melis, T.S., ed., Effects of three high-flow experiments on the Colorado River ecosystem downstream from Glen Canyon Dam, Arizona: U.S. Geological Survey Circular 1366, p. 93-126.

Korman, J., Kaplinski, M., and Melis, T.S., 2011, Effects of fluctuating flows and a controlled flood on incubation success and early survival rates and growth of age- 0 rainbow trout in a large regulated river: Transactions of the American Fisheries Society, v. 140, no. 2, p. 487505, accessed on April 19, 2011, at http://www.tandfonline.com/doi/abs/10.1080/00028487.2011.572015.

Korman, J., Wiele, S.M., and Torizzo, M., 2004, Modelling effects of discharge on habitat quality and dispersal of juvenile humpback chub (Gila cypha) in the Colorado River, Grand Canyon: River Research and Applications, v. 20, no. 4, p. 379-400, accessed on February 22, 2010, at http://www3.interscience.wiley.com/cgi-bin/fulltext/107614374/PDFSTART.

Marsh, P.C., and Douglas, M.E., 1997, Predation by introduced fishes on endangered humpback chub and other native species in the Little Colorado River, Arizona: Transactions of the American Fisheries Society, v. 126, no. 2, p. 343-346, accessed on August 19, 2011, at http://www.tandfonline.com/doi/abs/10.1577/15488659(1997)126\%3C0343:PBIFOE\%3E2.3.CO;2.

McKinney, T., Rogers, R.S., and Persons, W.R., 1999, Effects of flow reductions on aquatic biota of the Colorado River below Glen Canyon Dam, Arizona: North American Journal of Fisheries Management, v. 19, no. 4, p. 984-991, accessed on August 10, 2011, at http://dx.doi.org/10.1577/1548-8675(1999)019<0984:EOFROA >2.0.CO;2.

Melis, T.S., ed., 2011, Effects of three high-flow experiments on the Colorado River ecosystem downstream from Glen Canyon Dam, Arizona: U.S. Geological Survey Circular 1366, 147 p., accessed on June 28, 2011, at http://pubs.usgs.gov/circ/1366/.

Melis, T.S., Martell, S.J.D., Coggins, L.G., Pine, W.E., III, and Andersen, M.E., 2006, Adaptive management of the Colorado River ecosystem below Glen Canyon Dam, Arizona-using science and modeling to resolve uncertainty in river management, in Specialty Summer Conference on Adaptive Management of Water Resources, Missoula, Mont., June 26-28, 2006, Proceedings: American Water Resources Association, p. 1-6 (CD-ROM).

Minckley, W.L., 1991, Native fish of the Grand Canyon region-an obituary?, in Marzolf, G.R., ed., Colorado River ecology and dam management: Washington, D.C., National Academy Press, p. 124-177.

Porter, M.E., 2002, Riparian vegetation responses to contrasting managed flows of the Colorado River in Grand Canyon, Arizona: Flagstaff, Northern Arizona University, M.S. thesis, 33 p. Protiva, F.R., Ralston, B.E., Stone, D.M., Kohl, K.A., Yard, M.D., and Haden, G.A., 2010, Effects of Glen Canyon Dam discharges on water velocity and temperatures at the confluence of the Colorado and Little Colorado Rivers and implications for habitat for young-of-year humpback chub (Gila cypha): U.S. Geological Survey Open-File Report 2010-1137, 24 p., accessed on July 27, 2010, at http://pubs.usgs.gov/of/2010/1137/. 
Rogers, R.S., Persons, W.R., Rubin, D.M., Topping, D.J., Schmidt, J.C., Hazel, J., Kaplinski, M., and Melis, T.S., 2002, Recent sediment studies refute Glen Canyon Dam hypothesis: Eos Transactions, American Geophysical Union, v. 83, no. 25, p. 273, 277-278.

Schmidt, J.C., Topping, D.J., Grams, P.E., and Hazel, J.E., Jr., 2004, System-wide changes in the distribution of fine sediment in the Colorado River corridor between Glen Canyon Dam and Bright Angel Creek, Arizona - final report: Logan, Utah, submitted to U.S. Geological Survey, Grand Canyon Monitoring and Research Center, cooperative agreement no. 1425-98-FC-4022640, $107 \mathrm{p}$.

Schmidt, J.C., Topping, D.J., Rubin, D.M., Hazel, J.E., Jr., Kaplinski, M., Wiele, S.M., and Goeking, S.A., 2007, Streamflow and sediment data collected to determine the effects of low summer steady flows and habitual maintenance flows in 2000 on the Colorado River between Lees Ferry and Bright Angel Creek, Arizona: U.S. Geological Survey Open-File Report 20071268, 79 p., accessed on March 17, 2010, at http://pubs.usgs.gov/of/2007/1268/.

Speas, D.W., Persons, W.R., Rogers, R.S., Ward, D.L., Makinster, A.S., and Slaughter, J.E., IV, 2004, Effects of low steady summer flows on rainbow trout in the Lee's Ferry tailwater, 2000: Phoenix, Arizona Game and Fish, submitted to U.S. Geological Survey, Grand Canyon Monitoring and Research Center, cooperative agreement no. 1425-98-FC-40-22690, 38 p., accessed on August 23, 2011, at http://www.gcmrc.gov/library/reports/biological/Fish_studies/ AZGame\&Fish/2004/Speas2004.pdf.

Speas, D.W., Ward, D.L., Rogers, R.S., and Persons, W.R., 2003, Salmonid population size, relative density and distribution in the Colorado River in Grand Canyon during 2001 with reference to sample designs for long term monitoring - final report: Arizona Game and Fish Department, submitted to U.S. Geological Survey, Grand Canyon Monitoring and Research Center, cooperative agreement no. 02WRAG0030, 39 p. [Available upon request by contacting the Center Director, U.S. Geological Survey, Southwest Biological Science Center, 2255 N. Gemini Drive, Flagstaff, Ariz. 86001.]

Stevens, L.E., Ayers, T.J., Bennett, J.B., Christensen, K., Kearsley, M.J.C., Meretsky, V.J., Phillips, A.M., III, Parnell, R.A., Spence, J.R., Sogge, M.K., Springer, A.E., and Wegner, D.L., 2001, Planned flooding and Colorado River riparian trade-offs downstream from Glen Canyon Dam, Arizona: Ecological Applications, v. 11, no. 3, p. 701-710.

Topping, D.J., Rubin, D.M., and Vierra, L.E., Jr., 2000, Colorado River sediment transport, pt. 1 -natural sediment supply limitation and the influence of the Glen Canyon Dam: Water Resources Research, v. 36, no. 2, p. 515-542.

Trammell, M., Valdez, R.A., Carothers, S.W., and Ryel, R., 2002, Effects of a low steady summer flow experiment on native fishes of the Colorado River in Grand Canyon - final report: Flagstaff, Ariz., SWCA, Inc. Environmental Consultants, submitted to U.S. Geological Survey, Grand Canyon Monitoring and Research Center, cooperative agreement no. 99-FC40-2260, 77 p. [Available upon request by contacting the Center Director, U.S. Geological Survey, Southwest Biological Science Center, 2255 N. Gemini Drive, Flagstaff, Ariz. 86001.]

Urquhart, N.S., Auble, G.T., Blake, J.G., Bolger, D.T., Gerrodette, T., Leibowitz, S.G., Lightfoot, D.C., and Taylor, A.H., 2000, Report of a peer review panel on terrestrial aspects of the biological resources program of the Grand Canyon Monitoring and Research Center: submitted to U.S. Geological Survey, Grand Canyon Monitoring and Research Center, 50 p. [Available upon request by contacting the Center Director, U.S. Geological Survey, Southwest Biological Science Center, 2255 N. Gemini Drive, Flagstaff, Ariz. 86001.] 
U.S. Department of the Interior, 1995, Operation of Glen Canyon Dam Final Environmental Impact Statement: Salt Lake City, Utah, Bureau of Reclamation, Upper Colorado Region, 337 p.

U.S. Department of the Interior, 1996, Record of Decision, Operation of Glen Canyon Dam Final Environmental Impact Statement: Washington, D.C., Office of the Secretary of Interior, $15 \mathrm{p}$.

U.S. Fish and Wildlife Service, 1995, Final Biological Opinion on the Operation of Glen Canyon Dam: Albuquerque, N. Mex., consultation no. 2-21-93-F-167, 56 p.

U.S. Geological Survey, 1999, Final report of the physical resources monitoring peer review panel-Protocols Evaluation Program (PEP - SEDS): Flagstaff, Ariz., U.S. Geological Survey, Grand Canyon Monitoring and Research Center, $13 \mathrm{p}$.

Valdez, R.A., Carothers, S.W., House, D.A., Douglas, M.E., Ryel, R.J., Bestgen, K.R., and Wegner, D.L., 2000, A program of experimental flows for endangered and native fishes of the Colorado River in Grand Canyon - final report: Flagstaff, Ariz., SWCA, Inc. Environmental Consultants, submitted to U.S. Geological Survey, Grand Canyon Monitoring and Research Center, 68 p. [Available upon request by contacting the Center Director, U.S. Geological Survey, Southwest Biological Science Center, 2255 N. Gemini Drive, Flagstaff, Ariz. 86001.]

Vernieu, W.S., Hueftle, S.J., and Gloss, S.P., 2005, Water quality in Lake Powell and the Colorado River, in Gloss, S.P., Lovich, J.E., and Melis, T.S., eds., The state of the Colorado River ecosystem in Grand Canyon: U.S. Geological Survey Circular 1282, 69-85 p., accessed on May 10, 2010, at http://pubs.usgs.gov/circ/1282/.

Voichick, N., and Wright, S.A., 2007, Water-temperature data for the Colorado River and tributaries between Glen Canyon Dam and Spencer Canyon, Northern Arizona, 1988-2005: U.S. Geological Survey Data Survey Series 251, 24 p., accessed on January 14, 2010, at http://pubs.usgs.gov/ds/2007/251/.

Walters, C.J., and Holling, C.S., 1990, Large-scale management experiments and learning by doing: Ecology, v. 71, no. 6, p. 2060-2068, accessed on January 4, 2010, at http://www.jstor.org/stable/pdfplus/1938620.pdf.

Webb, R.H., Schmidt, J.C., Marzolf, G.R., and Valdez, R.A., eds., 1999, The 1996 controlled flood in Grand Canyon, v. 110: Washington, D.C., American Geophysical Union, Geophysical Monograph Series, $367 \mathrm{p}$.

Williams, B.K., Szaro, R.C., and Shapiro, C.D., 2007, Adaptive management-the U.S. Department of Interior technical guide: Adaptive Management Working Group, U.S. Department of the Interior, Washington, D.C.

Wright, S.A., Anderson, C.R., and Voichick, N., 2008, A simplified water temperature model for the Colorado River below Glen Canyon Dam: River Research and Applications, v. 25, no. 6, p. 675-686, accessed on August 19, 2011, at http://dx.doi.org/10.1002/rra.1179.

Yard, M.D., Blinn, D.W., 2001, Algal colonization and recolonization response rates during experimental low summer steady flows - final report: Northern Arizona University, submitted to U.S. Geological Survey, Grand Canyon Monitoring and Research Center, 60p. [Available upon request by contacting the Center Director, U.S. Geological Survey, Southwest Biological Science Center, 2255 N. Gemini Drive, Flagstaff, Ariz. 86001.]

Yard, M.D., Coggins, L.G., Baxter, C.V., Bennett, G.E., and Korman, J., 2011, Trout piscivory in the Colorado River, Grand Canyon - effects of turbidity, temperature, and fish prey availability: Transactions of the American Fisheries Society, v. 140, no. 2, p. 471-486, accessed on April 19, 2011, at http://www.tandfonline.com/doi/abs/10.1080/00028487.2011.572011. 
This page intentionally left blank 


\section{Chapter 2. Physical Resource Response to the Low Steady Summer Flow Experiment}

\section{Introduction}

Water temperature affects growth of young fish, and water velocity affects the environments they can occupy by affecting their swimming endurance. Water volume affects the warming potential of water and the velocity of water as it moves downstream. To benefit early life stages of native fish, particularly humpback chub (Gila cypha), the Low Steady Summer Flow (LSSF) experiment hydrograph incorporated different discharge volumes to affect velocities along shorelines, rework shorelines associated with sediment deposition, and to affect the warming potential of the water released from Glen Canyon Dam. The high, steady discharge in the spring was intended to pond tributaries to improve tributary spawning and retain larvae by creating low-velocity areas at the confluence areas. These high volumes of water would mobilize and rework sediment along shorelines that young fish could occupy later in the summer after entering the mainstem (Valdez and others, unpub. report, 2000). The lower water volume (226 $\mathrm{m}^{3} / \mathrm{s}$ ) in the summer was intended to create warm, low-velocity shoreline environments for young-of-year (YOY) and juvenile native fish. Ideally, warmer and slower velocity water along shoreline environments would result in greater growth of young native fish occupying mainstem shorelines; although, increased abundances of fish could limit growth of fish because of densitydependent effects.

Several researchers studied the effects of discharge on the temperature and velocity of water at the confluence with the Little Colorado River (LCR; fig. 2-1), in the mainstem, and along shorelines in 2000 (Davis, 2002; Korman and others, 2004; Protiva and others, 2010). Subsequently, Wright and others (2008) developed a model for mainstem warming potential that helps explain the mainstem warming patterns observed in 2000. The physical effects of the experimental hydrograph on sediment transport and shoreline reworking, specifically backwater rejuvenation, were studied in 2000 (Goeking and others, unpub. report, 2003; Schmidt and others, 2007), but primarily in association with the second habitat maintenance flow. Results from these studies are described in this chapter.

\section{Period I: Tributary Ponding}

Before the regulation of the Colorado River by Glen Canyon Dam, the average annual spring flood volume of the river in Grand Canyon was 2,407 $\mathrm{m}^{3} / \mathrm{s}$ : runoff began in March and peaked in May and June (Carothers and Brown, 1991; Topping and others, 2003). The timing of native fish spawning in tributaries is coincident with these historical flood peaks (Carothers and Brown, 1991; Valdez and Carothers, unpub. report, 1998; Gorman and Stone, 1999). Typically, during times of historical flooding, mainstem water would extend into tributary mouths and create extensive low-velocity pools that lasted for several months for larval and subsequent YOY fish (Robinson and others, 1998). Before regulation, mainstem water temperatures in April and May at Lees Ferry were likely equal to or greater than the average of $14.2^{\circ} \mathrm{C}$ recorded between 1955 and 1965 for these months upstream at the Green River gaging station near Green River, Utah (not shown; sta. number 09315000) (U.S. Geological Survey, 2010). This gage is located 
several hundred miles upstream from Lees Ferry and water temperatures may have increased as it traveled downstream. Although volumes would be high, the water in the mainstem would be approaching the optimal rearing and spawning temperatures of humpback chub, which are greater than or equal to $15^{\circ} \mathrm{C}$ and $16^{\circ} \mathrm{C}$, respectively (Bulkley and others, 1981), as it ponded in tributaries downstream from Lees Ferry. Robinson and others (1998) and Clarkson and Childs (2000) speculated that the younger fish would grow in these warmer tributary pools to a size that would allow them to manage mainstem velocities when the fish entered the receding mainstem flow in July.

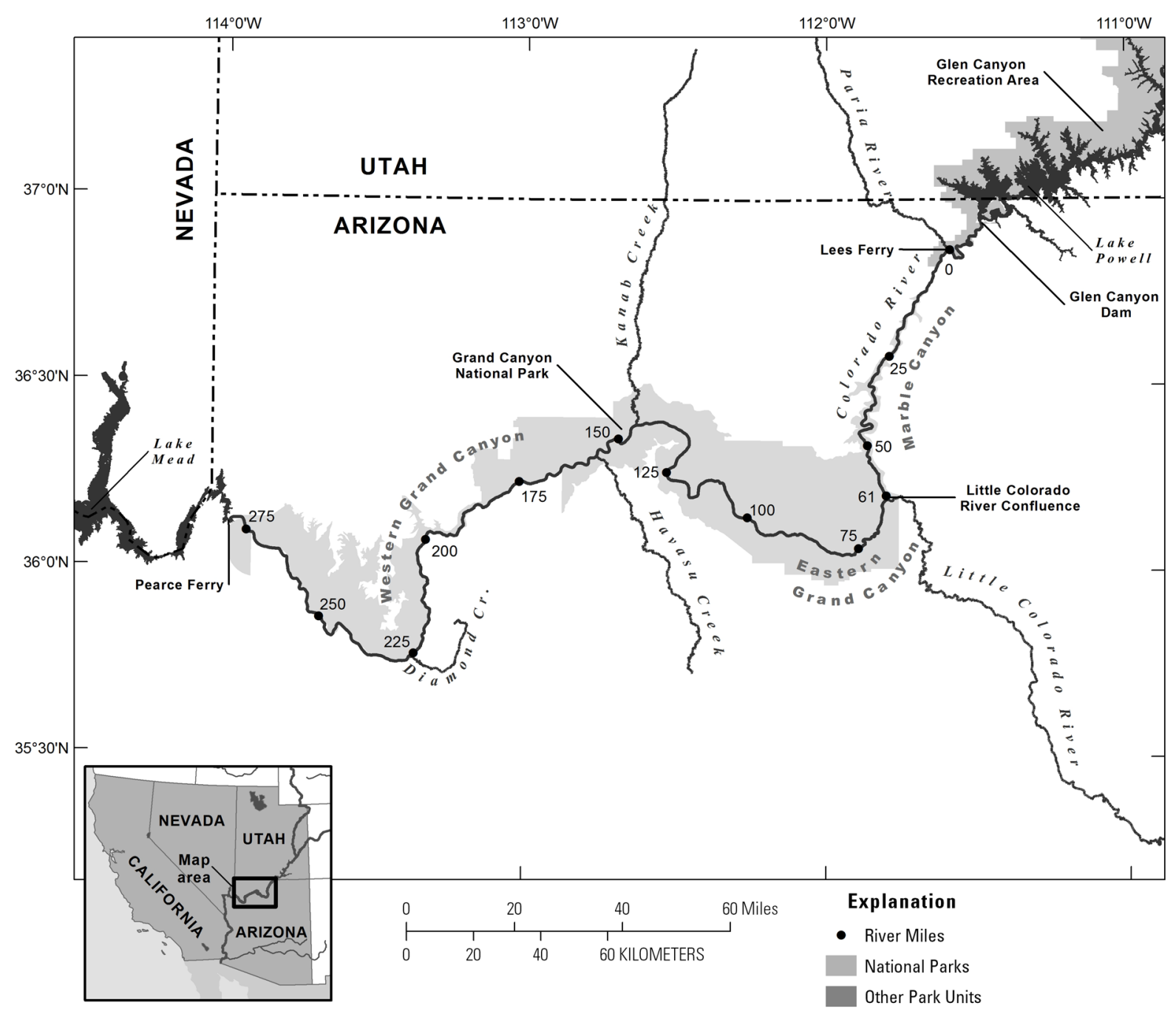

Figure 2-1. Map of the Colorado River downstream from Glen Canyon Dam. River mile (RM) designations occur at 25-mile intervals starting from Lees Ferry, designated as RM 0. Large tributaries to the mainstem, including the Little Colorado River, are identified.

Both the water temperatures and the maximum planned spring releases from Glen Canyon Dam in 2000 limited the potential benefit of tributary ponding. The high, steady discharges in Period I (April and May) of the LSSF hydrograph included discharges of 538 and $877 \mathrm{~m}^{3} / \mathrm{s}$ (fig. 1-4); these volumes were, respectively, 75 and 70 percent lower than predam 
volumes. In 2000, the maximum tributary ponding occurred for 4 days at the end of May during the $877 \mathrm{~m}^{3} / \mathrm{s}$ habitat maintenance flow (HMF). The 4-day ponding duration is a 93 -percent reduction compared to 2 months of ponding before regulation. Furthermore, in April and May of 2000, water temperatures at the Lees Ferry gaging station (sta. number 09380000), 15 miles downstream from Glen Canyon Dam, varied between 9.1 and $10.3^{\circ} \mathrm{C}$ (fig. 2-2; U.S. Geological Survey, 2010) and were 4 to $10^{\circ} \mathrm{C}$ lower than those upstream at the Green River gage for the same period (fig. 2-3; U.S. Geological Survey, 2010). The hypolimnetic releases (releases from the midpoint in the reservoir's elevation) from Glen Canyon Dam result in water temperatures that rarely exceed $12^{\circ} \mathrm{C}$ any time of the year except when the reservoir volume is reduced (Voichick and Wright, 2007). In 2000, the reservoir was full and water release temperatures in April and May were typical (Vernieu and others, 2005). High-volume discharges released in the spring intended to pond tributaries in the postdam Colorado River are unlikely to create a warmwater environment because colder water released from Glen Canyon Dam dominates the ponded areas.

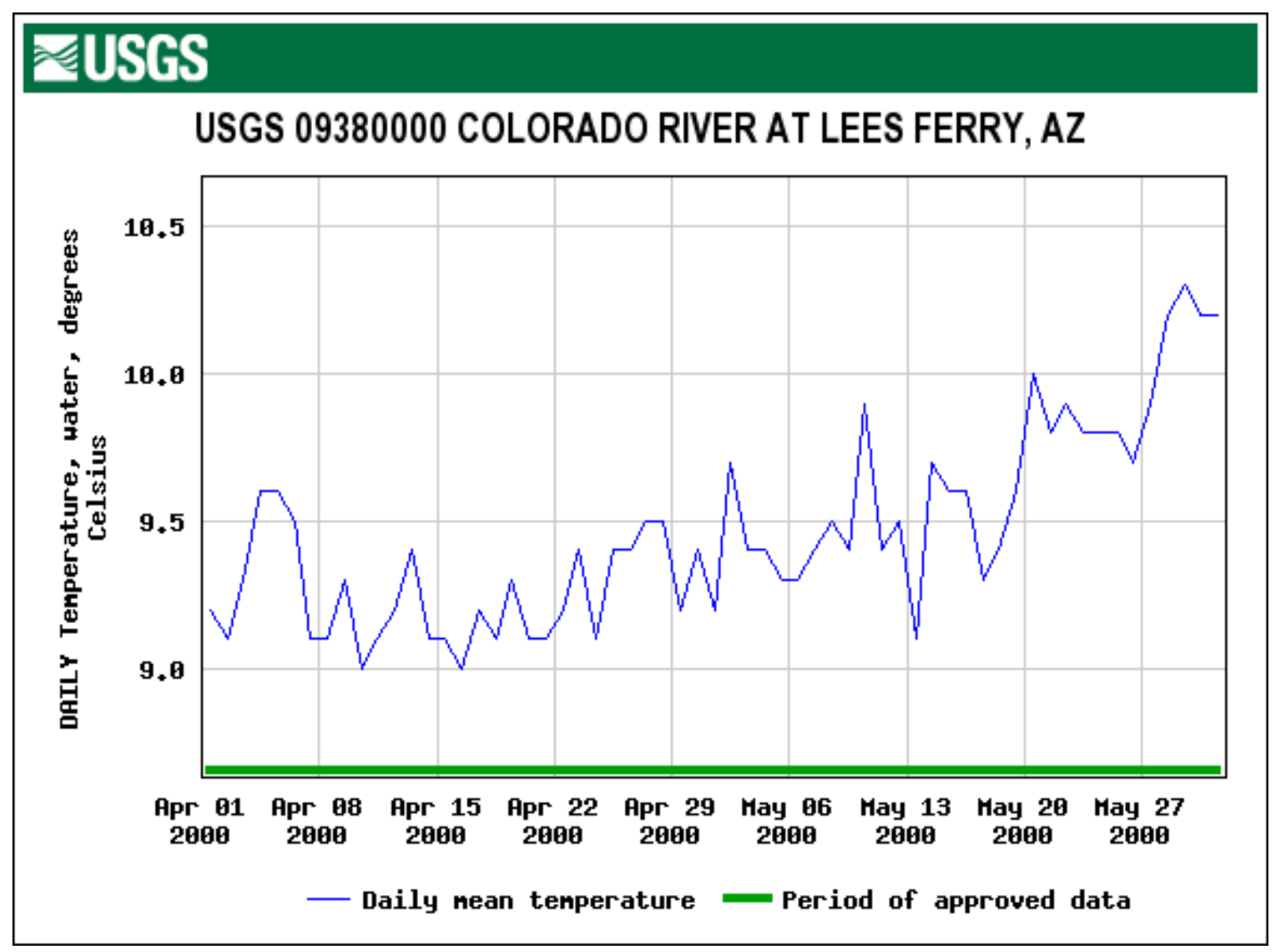

Figure 2-2. Mean daily temperatures $\left({ }^{\circ} \mathrm{C}\right)$ recorded at the gage at Lees Ferry, Ariz. (USGS 09380000), from April 1 through May 31, 2000. 


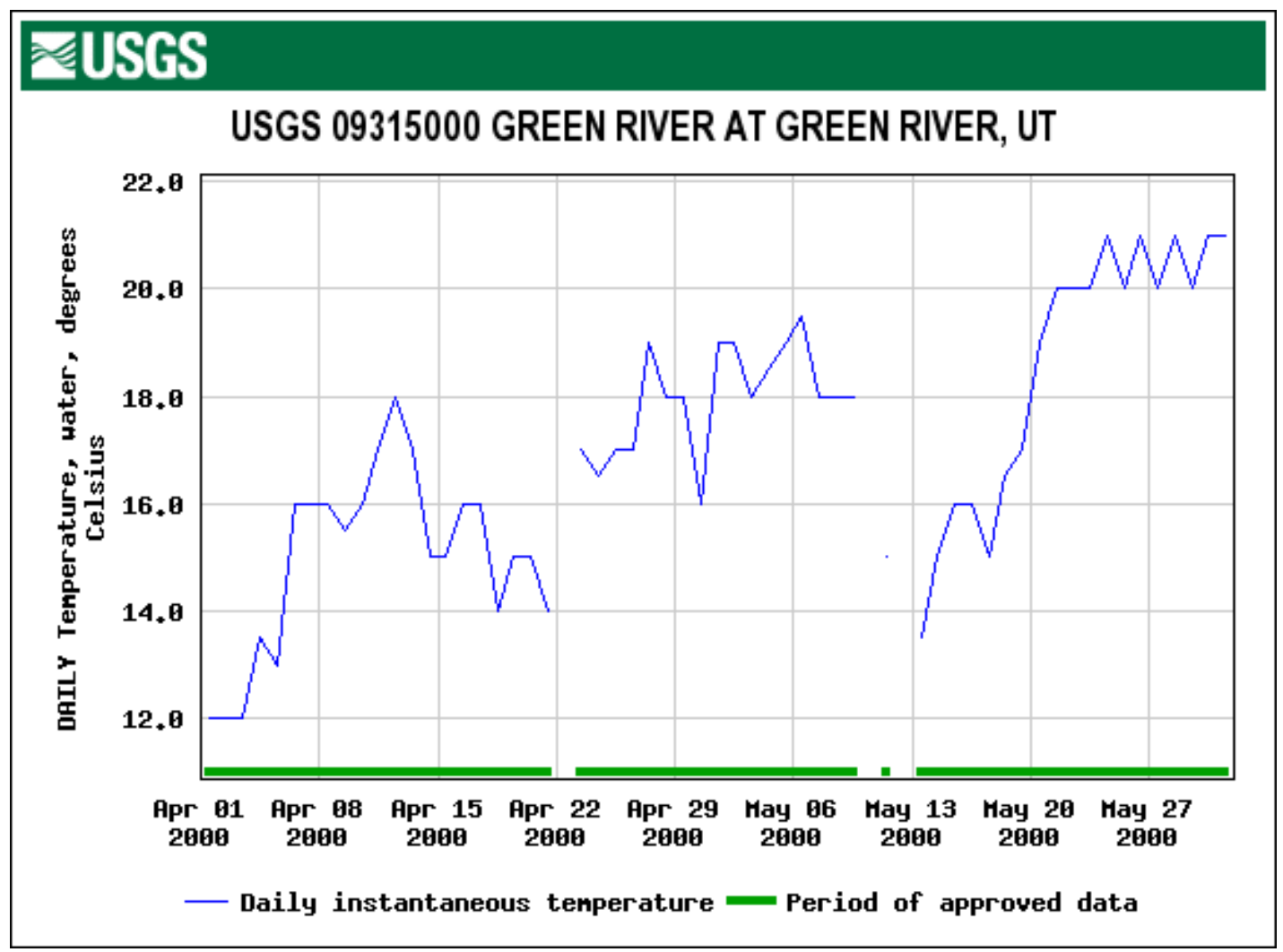

Figure 2-3. Mean daily temperatures $\left({ }^{\circ} \mathrm{C}\right.$ ) recorded at the gage at Green River, Utah (USGS 09315000), from April 1 through May 31, 2000.

Protiva and others (2010) studied the effect of increased mainstem discharge on water velocities and temperatures at the confluence of the LCR and the mainstem in the spring and summer of 2000 (fig. 2-1). They determined that as mainstem discharge volumes increase, the availability of low-velocity areas decrease at the confluence area (figs. 2-4 $A-C$ ). The greatest available low-velocity area occurred when discharges were between 226 and $509 \mathrm{~m}^{3} / \mathrm{s}$ (fig. 2$4 B$ ). The cobble island that is situated at the confluence affects the availability of low-velocity areas. Mainstem volumes that force LCR inflow into the channel on the south side of the island increased low velocity $(<0.2 \mathrm{~m} / \mathrm{s})$ water when the tributary was at base flow. Similarly, Protiva and others (2010) determined that warmwater areas $\left(>15^{\circ} \mathrm{C}\right)$ are limited to areas directly affected by the inflow from the LCR because the mainstem temperatures (typically $12^{\circ} \mathrm{C}$ even in the summer months) are lower than those of the LCR $\left(\geq 16^{\circ} \mathrm{C}\right.$; Voichick and Wright, 2007). In the spring, the potential benefit of ponding that might occur in the LCR decreases with higher discharges because the colder mainstem waters enter the ponded tributary mouth and reduce the area of warm water (fig. 2-5 $A-C$ ). 


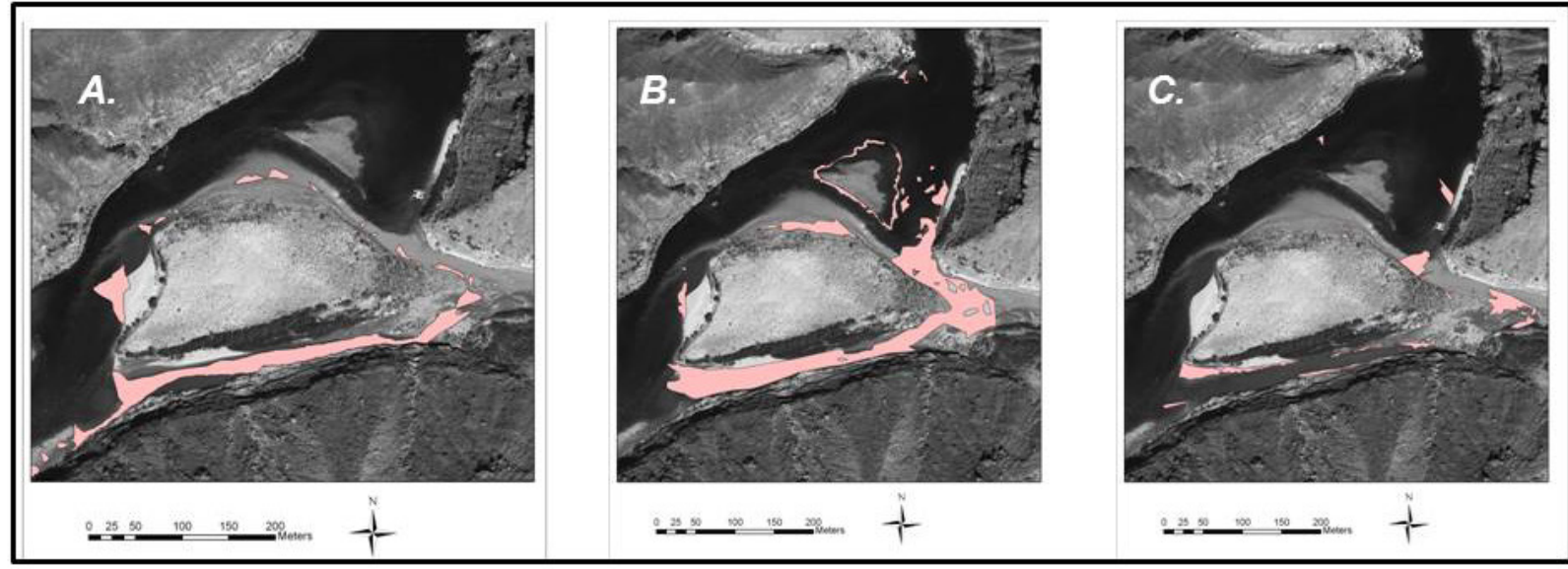

Figure 2-4. Available low velocity area $(\leq 0.2 \mathrm{~m} / \mathrm{s}$ and $\leq 1 \mathrm{~m}$ deep) at the confluence of the mainstem Colorado River and the Little Colorado River (LCR). Low-velocity areas (pink colored polygons) are superimposed on a black and white image of the confluence area taken in September 2000 when the mainstem discharge was $226 \mathrm{~m}^{3} / \mathrm{s}$. The light colored plume of sediment coming from the LCR in $(A)$ shows the direction the LCR inflow follows under a low mainstem discharge. When the mainstem discharge increases to $368 \mathrm{~m} / \mathrm{s}(B)$, ponding at the north side of the island occurs, LCR water is concentrated into the southern channel of the cobble bar, and low-velocity area increases and includes areas in the mainstem. When mainstem discharge reaches $509 \mathrm{~m}^{3} / \mathrm{s}(C)$, low-velocity area is significantly reduced at the confluence. At discharges $>509 \mathrm{~m}^{3} / \mathrm{s}$ (not shown), low-velocity area is limited to the LCR. Adapted from Protiva and others, 2010. 


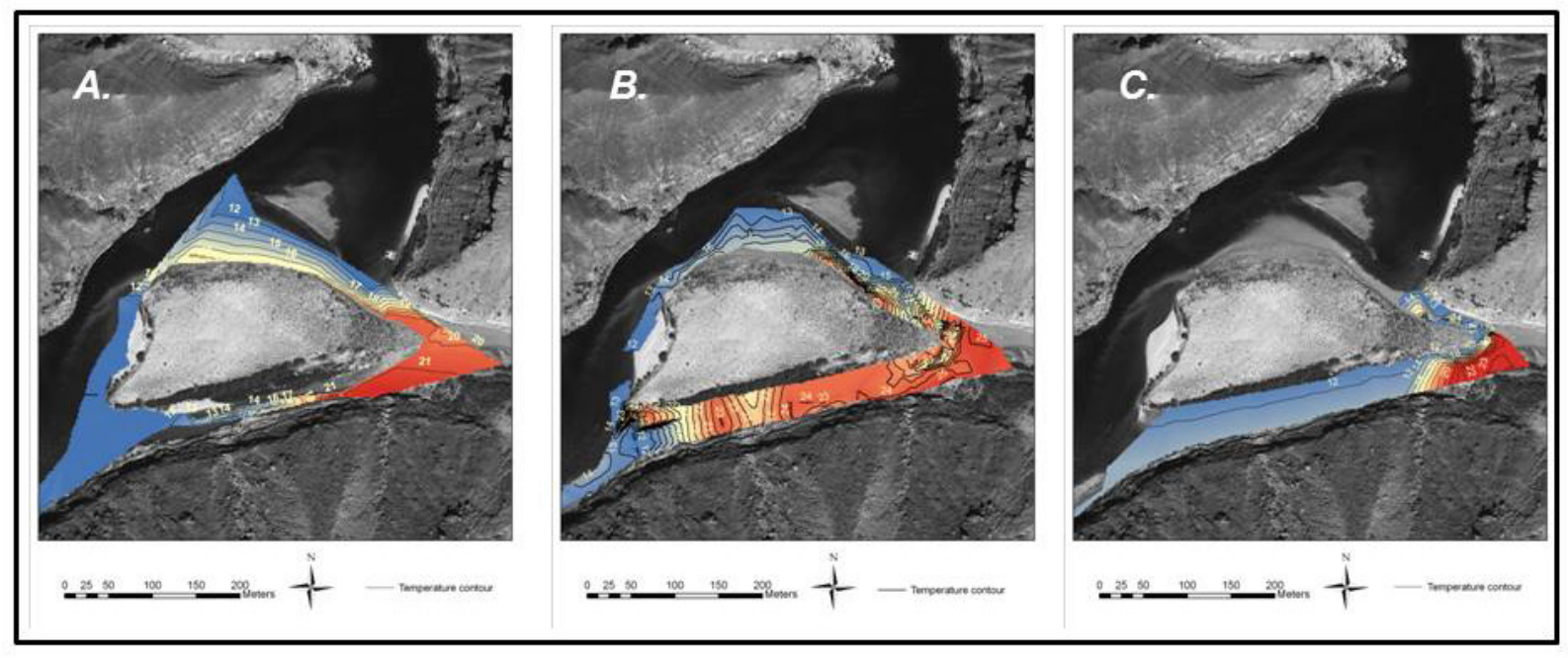

Figure 2-5. Available warmwater area ( $\leq 1 \mathrm{~m}$ deep) at the confluence of the Colorado River and the Little Colorado River (LCR). The images use $1{ }^{\circ} \mathrm{C}$ contours and graduated color, with darkest blue representing coldest temperatures $\left(12^{\circ} \mathrm{C}\right)$ and red representing the warmest water temperatures $\left(25^{\circ} \mathrm{C}\right)$ illustrate the warmwater areas associated with three mainstem discharges (227, 368 and $\left.509 \mathrm{~m}^{3} / \mathrm{s}\right)$. At discharges of $227 \mathrm{~m}^{3} / \mathrm{s}(A)$, warmwater areas are found in the LCR mouth and along the north side of the cobble island in association with the general direction of flow from the LCR. At a moderate discharge of $368 \mathrm{~m}^{3} / \mathrm{s}(B)$, available warmwater areas increase and shift toward the lower channel as water from the LCR is directed into the lower channel. At a mainstem discharge of $509 \mathrm{~m} 3 / \mathrm{s}(C)$, warmwater is limited to the mouth of the LCR because colder mainstem water is routed around the confluence and through the lower channel. Adapted from Protiva and others, 2010.

\section{Sediment Reworking and Habitat Rejuvenation Associated with a Habitat Maintenance Flow}

Historically, high-volume spring floods associated with basin snowmelt transported large quantities of sediment through Grand Canyon and reworked existing beaches and shorelines (Andrews, 1991; Schmidt and Rubin, 1995; Topping and others, 2003; Schmidt and others, 2004). The 4-day HMF of $877 \mathrm{~m}^{3} / \mathrm{s}$ that took place in the middle of Period I (May 3-6, 2000) was intended to rework sediment in eddies and along channel margins to create shoreline aquatic habitats, particularly backwaters (environments associated with recirculating eddies below debris fans) (Rubin and others, 1990; table 1-1). The HMF at $877 \mathrm{~m}^{3} / \mathrm{s}$ is a discharge that can be released without bypassing the turbines. Management agencies were interested in knowing if sandbars and backwaters could be maintained by flows that did not bypass the powerplant. Hypothetically, YOY fish would occupy the reworked backwaters and other shoreline habitats during the summer. Sandbar building and sediment export are dependent on the balance between accumulated sediment volumes in eddies and the channel, and available sediment storage space at higher stage elevations (Topping and others, 2000b; Hazel and others, 2006). A sedimentstarved river subjected to a sustained high-discharge event can export more sediment than is stored in the river channel (Rubin and others, 2002; Wright and others, 2006).

Results of sediment input monitoring before the sustained discharge of $481 \mathrm{~m}^{3} / \mathrm{s}$ in April 2000 and the May HMF indicated that there were few sediment inputs from tributaries to the mainstem in the previous winter months and that accumulated sediment in the eddies was low (Schmidt and others, 2007). In the Colorado River downstream from Glen Canyon Dam, 
sustained discharges greater than $282 \mathrm{~m}^{3} / \mathrm{s}$ increase the amount of sediment exported from the system-flows of $424 \mathrm{~m}^{3} / \mathrm{s}$ transport 2 to 10 times more sediment than flows of $282 \mathrm{~m}^{3} / \mathrm{s}$ (Topping and others, 2000a, 2006). Schmidt and others (2007) identified Period I, with 2 months of high discharges, as a sediment-exporting period. Despite the export of sediment, results from ground-based surveys of sandbars and eddies in June 2000 indicated that some sediment was deposited along higher elevation sandbars and that sediment volumes in submerged eddies decreased (Hazel and others, 2006; Schmidt and others, 2007). Because of the low amount of sediment inputs in the previous winter months, the area and volume changes observed were likely because of reworking of sediment from local sandbar sources rather than from sediment that accumulated in the eddies through the winter.

Although the higher elevation sandbars (elevations equivalent to river stages associated with discharges $>708 \mathrm{~m}^{3} / \mathrm{s}$ ) do not constitute shoreline habitat, the reduced sediment volumes previously scoured from submerged eddy deposits might indicate increased backwater volumes. Changes in backwater areas were determined following the September HMF. Sediment inputs from tributaries also were low in the summer of 2000 (Schmidt and others, 2007). Results from the September analysis indicate that the areas of backwaters located in the vicinity of the LCR either increased or remained the same following the September HMF (fig. 2-6; Goeking and others, unpub. report, 2003; Schmidt and others, 2007). The changes in backwater area were associated with measured declines in sand volume in submerged eddies and increased area in mid-elevation sandbars (Goeking and others, unpub. report, 2003; Schmidt and others, 2007). Because sand volume deposited in submerged eddies decreased during the May HMF (Hazel and others, 2006; Schmidt and others, 2007), just as it did during the September HMF, it can be inferred that the spring HMF likely created or enlarged backwater areas before the June steady flow period, but the extent of change is unknown.

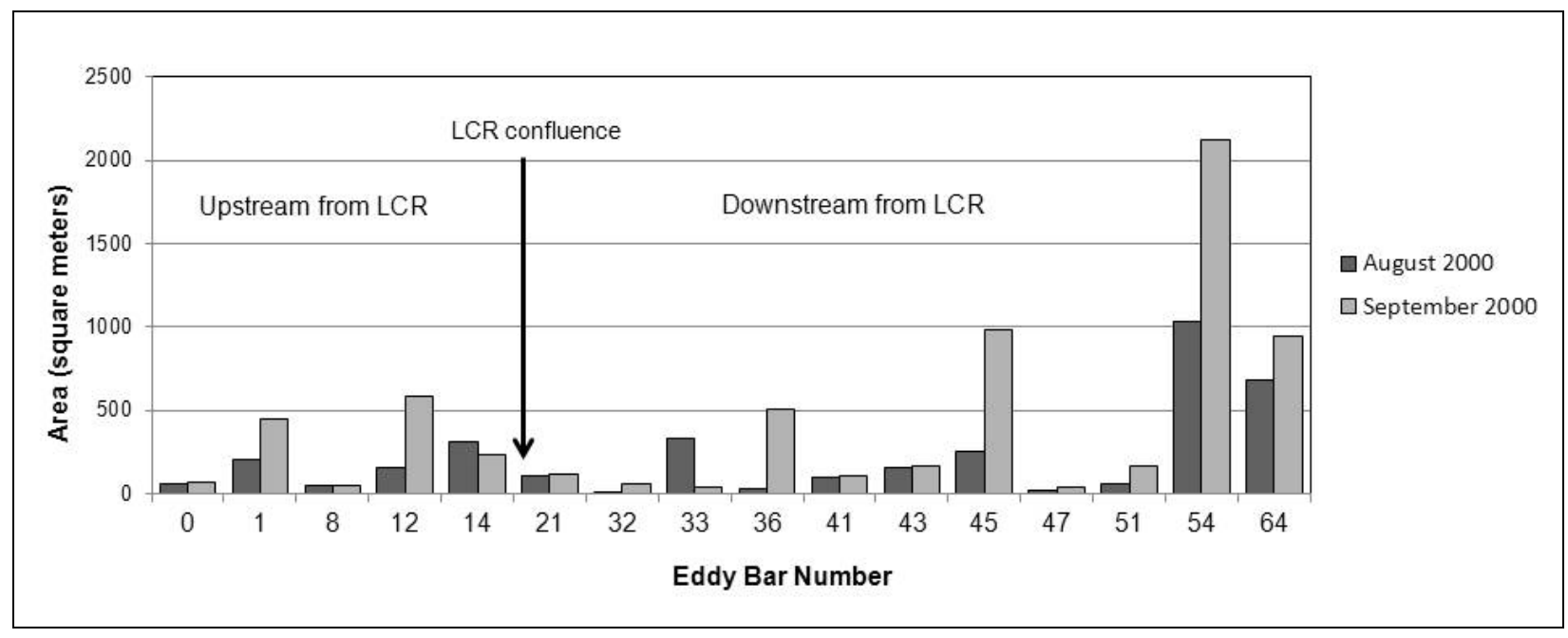

Figure 2-6. Backwater area in August and September 2000 upstream and downstream from the Little Colorado River (LCR). A 4-day $877 \mathrm{~m}^{3} / \mathrm{s}$ habitat maintenance flow occurred between the two sampling events. Data from Goeking and others (unpub. report, 2003). 


\section{Period II: Mainstem and Shoreline Warming during Low Steady Discharges from June to August 2000}

A primary hypothesis associated with Period II of the LSSF experiment was that the low steady discharges of $226 \mathrm{~m}^{3} / \mathrm{s}$ would provide low velocity, stabilized shoreline environments for YOY and juvenile fish from June through September. Lower volumes presumably also would promote warmwater $\left(\geq 16^{\circ} \mathrm{C}\right)$ environments (Valdez and others, unpub report, 2000; table 1-1, fig. 1-4). Water at least as warm as $16^{\circ} \mathrm{C}$ was the target temperature for the mainstem because optimal spawning temperatures for humpback chub is at least $16^{\circ} \mathrm{C}$ (Bulkley and others, 1981 ; Valdez and Ryel, unpub. report, 1995; Valdez and Carothers, unpub. report, 1998). The optimum rearing temperatures for humpback chub range between 15 and $24^{\circ} \mathrm{C}$ (Bulkley and others, 1981; Valdez and Ryel, unpub. report, 1995; Valdez and Carothers, unpub. report, 1998). Water release temperature in the Colorado River from Glen Canyon Dam varies between 9 and $12^{\circ} \mathrm{C}$ (Vernieu and others, 2005; Voichick and Wright, 2007), which limits potential for either spawning or rearing of humpback chub in the mainstem. As a result of lower mainstem temperatures, growth of fish is reduced (Clarkson and Childs, 2000). Before 2000, release temperatures reached $15^{\circ} \mathrm{C}$ only in the early 1980s when the reservoir was still filling (Vernieu and others, 2005; Voichick and Wright, 2007).

Valdez and others (unpub. report, 2000) anticipated that water in the mainstem would reach minimum spawning and rearing temperature requirements for humpback chub by the Middle Granite Gorge (RM 126, not shown). Release temperatures from Glen Canyon Dam in June through August 2000 were between 9.4 and $9.5^{\circ} \mathrm{C}$ (Voichick and Wright, 2007). Mainstem water temperatures immediately upstream from the LCR (RM 61.0, fig. 2-1) did not meet optimal rearing temperatures during any time of Period II. Temperatures further downstream did reach rearing temperatures from at least RM 132 (not shown), near the Middle Granite Gorge humpback chub aggregation, to RM 225 (fig. 2-7). 


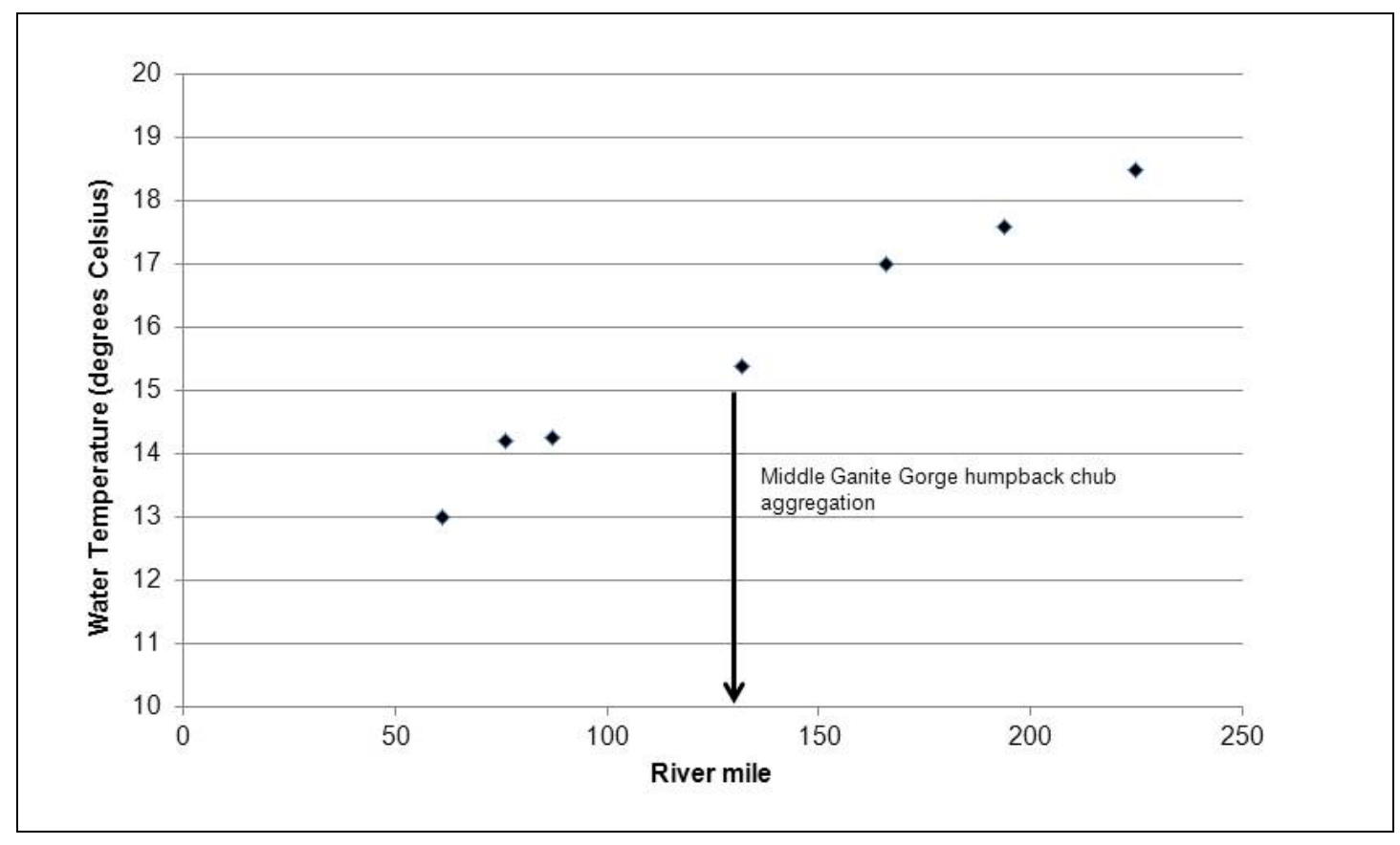

Figure 2-7. Mean water temperatures from June through September 2000 from river mile (RM) 62 to 225. The location of the Middle Granite Gorge humpback chub aggregation (RM 132) is identified by the arrow (data adapted from Voichick and Wright, 2007).

Reservoir conditions, time of year, rate of discharge, and distance downstream from the dam affect mainstem water temperature (Anderson and Wright, 2007; Wright and others, 2008). Reservoir elevation affects release temperatures from Glen Canyon Dam by affecting the withdrawal depth of water entering the penstocks (Vernieu and others, 2005; Wright and others, 2008). The rate at which water is discharged from the dam affects residence time in the river channel. Water discharged at lower rates has a longer residence time in the river channel and, if air temperatures are high, warming can occur (Korman and Campana, 2009; Wright and others, 2008). The greatest mainstem warming occurs in July, which is coincident with the greatest value recorded for average monthly air temperature (for example, $28.4^{\circ} \mathrm{C}$ average monthly temperature at Page, Ariz. (Wright and others, 2008)). July also is when humpback chub frequently enter the mainstem from tributaries in association with tributary freshets from monsoon storms (Valdez and Ryel, unpub. report, 1995).

A general pattern of mainstem warming in Grand Canyon is that initial release temperatures from Glen Canyon Dam affect water temperature in the upper reaches of the Colorado River (for example, at RM 61 near the LCR). Water temperature in lower reaches of the river is affected by three physical properties: discharge rate, which affects residence time (Anderson and Wright, 2007; Wright and others, 2008); channel aspect, which affects light availability; and air temperature, which is generally greater in the western portion of Grand Canyon (Yard and others, 2005). Mainstem water temperatures near the LCR cannot reach $16^{\circ} \mathrm{C}$ in July and August unless release temperatures approach $14^{\circ} \mathrm{C}$ (Wright and others, 2008). In contrast, warmer mainstem temperatures are attainable in the western part of the Colorado River 
in July when releases from Glen Canyon Dam are $12^{\circ} \mathrm{C}$ because of the longer residence time of water in the river channel.

The rate of river warming from the dam downstream from the LCR was similar in 2000 to that observed in previous years under Modified Low Fluctuating Flow (MLFF) operations. Downstream of the LCR, warming of water is dependent on the discharge rate and air temperature, which affects local warming (Korman and others, unpub. report, 2006; Anderson and Wright, 2007; Wright and others, 2008). Release temperatures in 2000 were $1^{\circ} \mathrm{C}$ warmer than in previous years, which accounted for the $13^{\circ} \mathrm{C}$ water temperatures observed in the mainstem near the LCR during the experiment (Voichick and Wright, 2007). For mainstem water temperatures to reach optimal rearing temperatures for humpback chub at the confluence with the LCR, release temperatures needed to be greater than $13^{\circ} \mathrm{C}$. Mainstem warming in 2000 was greatest in the western reaches of the mainstem (fig. 2-7) because of lower discharges rates, compared with previous years, and longer residence time in the channel by the time the water traveled 225 miles to Diamond Creek (fig. 2-1) in 2000 compared with the years 1993-99.

Similar patterns of mainstem water warming observed under steady discharges during the summer of 2000 occurred in 2005 during higher discharges and MLFF operations (Voichick and Wright, 2007). In 2005, release temperatures during the summer months averaged $13.2^{\circ} \mathrm{C}$, approximately $4^{\circ} \mathrm{C}$ warmer than in 2000 , and monthly volumes were $141 \mathrm{~m}^{3} / \mathrm{s}$ greater in June through August compared to 2000. Water temperatures at RM 61 were between 15 and $16^{\circ} \mathrm{C}$ in July and August, approximately $1^{\circ} \mathrm{C}$ warmer than temperatures at Lees Ferry. The pattern observed in 2005 illustrates how release temperatures affect downstream warming patterns. Even during higher discharges and higher daily ranges of discharge, downstream warming that meets optimal rearing temperature requirements of humpback chub is achievable in the mainstem near the LCR, if initial release temperatures are greater than $13^{\circ} \mathrm{C}$. The mainstem water temperatures during 2000 may have benefitted fish in the western parts of Grand Canyon where mainstem temperatures reached optimal rearing temperature requirements for humpback chub.

\section{Period II: Shoreline Warming}

The variables of water volume, residence time, and ambient temperatures that affect mainstem warming also affect warming of water along the shoreline (Korman and others, unpub. report, 2006). Time of year also affects how water temperatures might differ between shoreline environments and the mainstem. Geomorphic features associated with low-velocity shorelines (for example, talus and backwaters) affect residence time of water by affecting the degree to which water is isolated from and mixes with mainstem water. Korman and others (unpub. report, 2006) collected temperature data from August through October 2004 in low- and high-angle shoreline habitats and in backwaters in the mainstem during fluctuating discharges. The greatest warming was associated with backwaters, followed by low-angle shorelines. Water temperatures at steep-angled talus environments were similar to the mainstem (Korman and others, unpub. report, 2006). Individual backwater habitat may warm substantially more than the mainstem during parts of the day (Korman and others, unpub. report, 2006) depending on the orientation of the backwater to the sun and time of year. Backwater and mainstem temperature data from September 2005 (Ralston and others, 2007) indicated no difference in temperature between these environments during steady $\left(226 \mathrm{~m}^{3} / \mathrm{s}\right)$ and low discharge fluctuating releases, which likely reflect the time of year and the effect of local air temperature on warming.

The depth of warming in the water column reported by Korman and others (unpub. report, 2006) indicated that water temperatures measured below daily base-flow stage elevations 
along shorelines varied little from the mainstem. Shoreline water temperature associated with vertical stratification was not measured during the LSSF experiment. Korman and others (unpub. report, 2006) also indicated that shoreline temperatures reverted to mainstem temperatures at night or during indirect sunlight conditions. These results corroborate the findings of Ralston and others (2007), who reported little difference between mainstem and backwater temperatures measured in September and October 2005, when sun angle is low and air temperatures are correspondingly lower. Data from 2000 indicated similar warming in a backwater at RM 141 (William Vernieu, U.S. Geological Survey, unpub. data, 2011). At that backwater, the nighttime temperatures differed by $3.5^{\circ} \mathrm{C}$ between the backwater and the mainstem, while the daytime temperatures differed by $13.0^{\circ} \mathrm{C}$. Ralston and others (2007) also indicate that areas closest to the shoreline, which are therefore shallower environments, warmed more than areas farther from the shoreline. In 2000, as in other years during MLFF operations, water in backwaters warmed during the day and was warmest during the warmest period of the summer.

\section{Period II: Surface Warming Patterns during Steady Flows}

A $1-\mathrm{m}^{2}$ resolution thermal infrared sensor recorded maximum water-surface temperatures along a 42-mile stretch of the river channel (RM 30-72) at 1:30 p.m. on July 21, 2000 (Davis, 2002). Water-surface thermal data are presented here for a total 44.6 ha of areas that extend $2 \mathrm{~m}$ from shorelines to quantify the area and pattern of shoreline warming (fig. 2-8). The areas that were measured included areas around mid-channel islands, cobble bars, debris fans, eddy bars, and associated backwaters.

Water-surface temperatures along the shorelines varied from 9 to $28^{\circ} \mathrm{C}$ (Davis, 2002). More than 50 percent of the shoreline temperatures were similar to the mainstem temperatures during steady flows even in July at maximum light availability (fig. 2-8). Mainstem watersurface temperatures near the LCR averaged $13.5^{\circ} \mathrm{C}$. Water-surface temperatures between 13 and $14^{\circ} \mathrm{C}$ accounted for the largest proportion of all shoreline areas. Water-surface temperature for some areas reached optimal rearing temperatures for humpback chub.

Fragmented water-surface warming patterns occurred along shorelines in 2000. As identified by Korman and others (unpub. report, 2006), shoreline warming is not uniform because water in eddies warms more than water along talus slopes. In general, in 2000 , backwaters had the largest contiguous areas of water with surface temperatures greater than $16^{\circ} \mathrm{C}$. The area near the confluence with the LCR also was a large area of warm surface temperatures that equaled or exceeded $16^{\circ} \mathrm{C}$. This area could be a transition zone for young humpback chub during lower dam releases and could reduce temperature shock to small-sized fish. These data complement the subsurface temperature study of Protiva and others (2010). Shoreline surface temperatures warmed in a downstream pattern in July 2000 (Davis, 2002), similar to what was observed for the mainstem (fig. 2-7). 


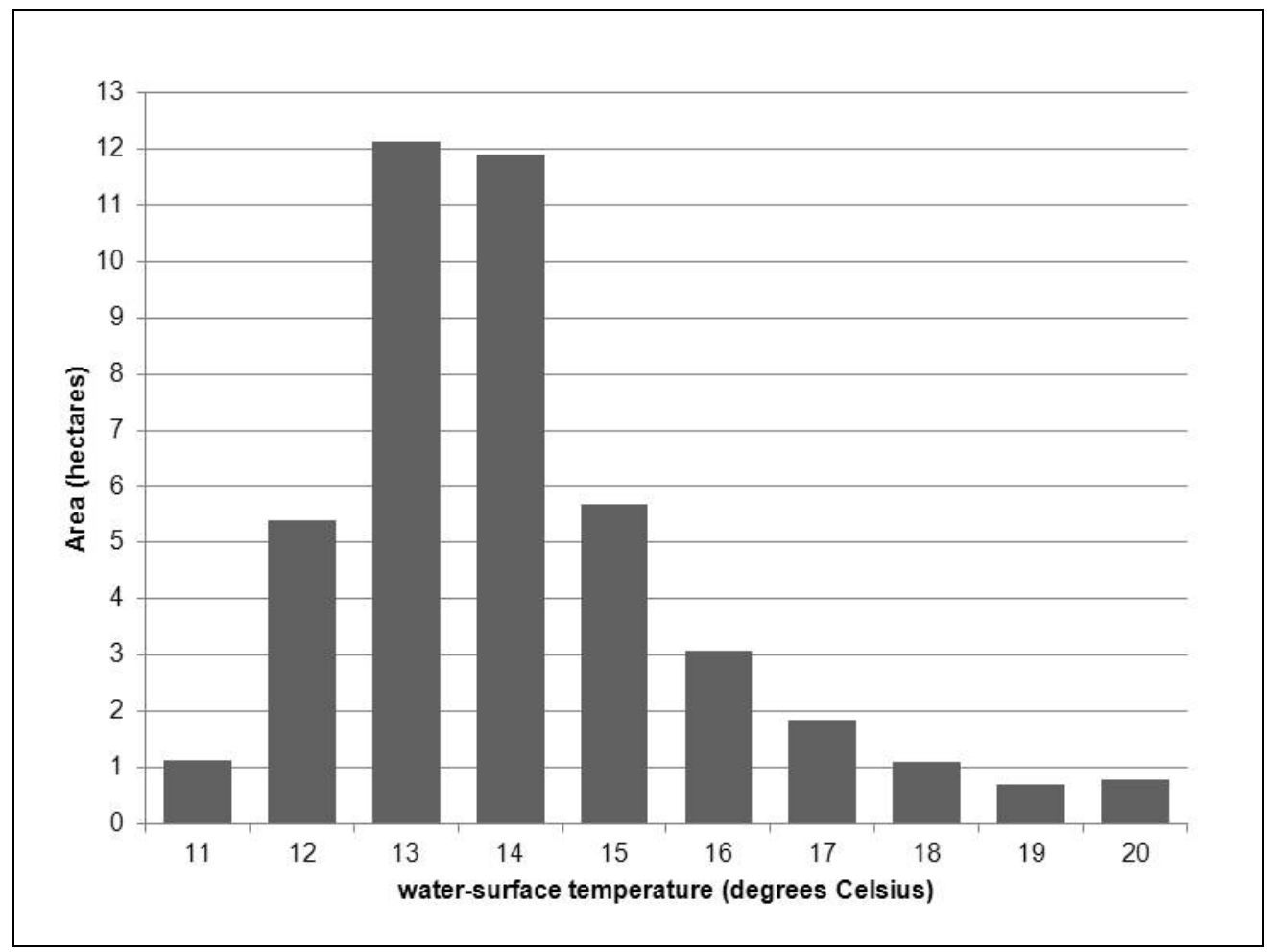

Figure 2-8. Area distribution greater than or equal to 0.5 hectares of the water-surface temperatures within $2 \mathrm{~m}$ from the shoreline, river mile 30-72, 1:30 p.m., July 21, 2000.

\section{Period II: Low Steady Summer Discharges and Shoreline Habitat for Fish}

Persistent suitable habitat is a key variable for early life-stage survival and subsequent recruitment of fish into the adult population (Freeman and others, 2001; Korman and others, 2004; Korman and Campana, 2009). Previous surveys of backwater area for discharges that range from 141 to $849 \mathrm{~m}^{3} / \mathrm{s}$ (McGuinn-Robbins, unpub. report, 1995) and habitat suitability studies for humpback chub (Converse and others, 1998) identified that a steady discharge of 226 $\mathrm{m}^{3} / \mathrm{s}$ increased low-velocity shoreline habitats compared with higher discharges. Korman and others (2004) modeled shoreline habitats for a section of river downstream from the LCR for discharges between 141 and $788 \mathrm{~m}^{3} / \mathrm{s}$. The habitat study by Converse and others (1998) identified the amount and types of shoreline habitats available at the proposed $226 \mathrm{~m}^{3} / \mathrm{s}$ discharge and at other discharges. Korman and others (2004) also evaluated how persistent habitat varied with monthly discharge since regulation.

\section{Available Habitat and Habitat Stability}

Korman and others (2004) used velocity $(\leq 0.25 \mathrm{~m} / \mathrm{s})$, water depth $(<1 \mathrm{~m})$ and shoreline types (for example, talus, vegetation, cobbles) to quantify suitable shoreline environments within seven geomorphic reaches downstream from the LCR for discharges ranging from 82 to 2,830 $\mathrm{m}^{3} / \mathrm{s}$. The physical constraints they selected for depth and velocity were based on studies of swimming performance and shoreline locations of young humpback chub (Bulkley and others, 1981; Valdez and Ryel, unpub. report, 1995; Converse and others, 1998). Korman and others (2004) determined that discharge rates and local morphology affect local velocities and the 
amount and availability of shoreline habitat. Reaches with large debris fans, steep profiles, and associated large downstream eddies changed little with increasing discharge except when discharges overtopped debris fans (for example, discharges of 2,830 $\mathrm{m}^{3} / \mathrm{s}$ ). Generally, total suitable habitat declined with increasing discharge (Korman and others, 2004).

When discharges were either greater than $424 \mathrm{~m}^{3} / \mathrm{s}$ or less than $226 \mathrm{~m}^{3} / \mathrm{s}$, suitable shoreline habitat declined by 50 percent (Korman and others, 2004). Similarly, Protiva and others (2010) found discharges greater than $424 \mathrm{~m}^{3} / \mathrm{s}$ reduced low-velocity habitats at the confluence of the LCR (fig. 2-4). Because Korman and others (2004) encountered variability between suitable habitat and discharge rates within their short study reach $(3.6 \mathrm{~km})$, they suggested that general trends about stage elevation and habitat availability could not be determined for the whole river system. Further analysis could be done as shoreline mapping is completed and sandbar- and reach-based velocity models are developed to explore the variability across geomorphic reaches for a range of discharges.

Comparisons of predam and postdam average monthly discharges were made to determine how regulation changed seasonal shoreline habitat availability (Korman and others, 2004). The authors note that predam seasonal discharges were higher in the May and June periods (averaging 1,500 $\mathrm{m}^{3} / \mathrm{s}$ ) than during postdam regulation (averaging $400 \mathrm{~m}^{3} / \mathrm{s}$ ). These high predam discharges, which also were warmer, exceed those imposed during Period I of the LSSF experiment by 275 percent and would have resulted in extensive ponding at tributaries. Korman and others (2004) noted that the annual base discharge increased from 226 to $300 \mathrm{~m}^{3} / \mathrm{s}$ (based on monthly averages), or 32 percent, for the period of record since regulation began in 1963 . Korman and others (2004) noted that regulation substantially reduced suitable shoreline habitat for the months of August through February and increased suitable shoreline habitat for 3 months of the year (April-June). YOY native fish, particularly humpback chub, are few in number in the mainstem from April through June, but their abundances increase in the later summer months (Valdez and Ryel, unpub. report, 1995) even though suitable habitat is reduced during MLFF operations after June.

Korman and others (2004) found that the LSSF experiment provided consistent suitable habitat that was absent during other regulated discharge patterns. They concluded that the LSSF experiment that included $226 \mathrm{~m}^{3} / \mathrm{s}$ discharges in June and July did not mimic the predam pattern of discharge or minimum flows for these same months. The timing of the September HMF (September 1-4) served as an interruption in persistent habitat at a time when YOY native fish likely are occupying mainstem shoreline habitats, mainstem discharges were historically low, and mainstem water was still warm. The results from Korman and others (2004) report suggest YOY fish might benefit more from a low steady flow period that started later in the summer season, such as August. The delayed timing might benefit YOY fishes entering the mainstem from tributaries during monsoon flooding. The resulting reduction in base flow in August compared to MLFF could provide maximum shoreline habitats coupled with warmer water released from Lake Powell (fig. 2-1; Vernieu and others, 2005) and greater ambient air temperatures (Wright and others, 2008). Releasing lower discharges later in the summer season also would help conserve sediment inputs associated with late summer and fall monsoonal storms. Lower discharges reduce sediment transport (Topping and others, 2000a; Schmidt and others, 2007). The sediment could be reworked and deposited in higher elevation sandbars during higher discharges (Rubin and others, 2002; Wright and others, 2006; Wright and Kennedy, 2011).

Period II of the LSSF experiment began following a HMF intended to rework eddies and rejuvenate backwaters. As mentioned in the description of Period I, the HMF in May mobilized 
sediment resulting in some accumulation of sand at mid-elevation sandbars and a reduction in sand volume in eddies, suggesting that backwaters were reworked (Hazel and others, 2006; Schmidt and others, 2007). The September HMF also resulted in deposition of sediment in the mid-elevation sandbars (Schmidt and others, 2007) and increased backwater area in September (Goeking and others, unpub. report, 2003; fig. 2.6). The response was not uniform among all eddies or reaches (Goeking and others, unpub. report, 2003), which corresponds to results of modeling done by Korman and others (2004). Goeking and others (unpub. report, 2003) commented that the total backwater area in 2000 was comparable to that measured in 1984 following the largest postdam releases $\left(2,747 \mathrm{~m}^{3} / \mathrm{s}\right)$ in 1983 .

\section{Conclusions}

The high discharges associated with Period I $\left(481 \mathrm{~m}^{3} / \mathrm{s}\right)$ were insufficient to create extensive ponding at the LCR, and the dynamics between mainstem temperatures and tributary mouths created a cold, low-velocity water interface rather than a warmwater interface that could be beneficial for larval and YOY fish (Protiva and others, 2010). The low steady flows of Period II were associated with average mainstem temperatures for comparable discharges during fluctuating flows (Voichick and Wright, 2007) - mainstem temperatures in the eastern Grand Canyon were similar to previous years during MLFF operations. Nearshore warming exceeded mainstem temperatures in some places by as much as $13^{\circ} \mathrm{C}$ (Davis, 2002), but less than 50 percent of the shoreline water-surface area that was measured by thermal infrared imagery was warmer than $14^{\circ} \mathrm{C}$ (fig. 2.8). Warming was not continuous along shorelines, resulting in fragmented water-surface warming (Davis, 2002). Korman and others (unpub. report, 2006) concluded that backwaters that have a reduced connection with the mainstem and slower velocities reached the highest water temperatures measured in 2004 during MLFF operations, suggesting that similar warming occurred in 2000. Shoreline warming occurred in 2004 and 2005 during MLFF operations that were coincident with warmer release temperatures (Johnstone and Lauretta, unpub. report, 2006). The warmer mainstem temperatures observed in 2004 and 2005 may have resulted in more uniform temperatures between the mainstem and shorelines. The daily temperature flux between the shoreline and mainstem temperatures within the vertical water column may have been less in 2004 and 2005 than in 2000. The basin hydrology that affects Lake Powell Reservoir elevations and subsequent release temperatures may be more important for providing warm mainstem water than the daily discharge pattern. The linkage between warm mainstem water and persistent habitat needs for fish remain unclear and further study would be needed to better understand the linkages.

\section{References}

Anderson, C.R., and Wright, S.A., 2007, Development and application of a water temperature model for the Colorado River ecosystem below Glen Canyon Dam, Arizona, in Hromadka, T., ed., The American Institute of Hydrology and Technology, 2007 Annual Meeting and International Conference - Integrated Watershed Management-Partnerships in Science, Technology and Planning, Reno, Nev., April 22-25, 2007, Proceedings: v. 23 (1-4), p. 13-26. Andrews, E.D., 1991, Sediment transport in the Colorado River Basin, in Marzolf, G.R., ed., Colorado River ecology and dam management: National Academy Press, p. 54-74.

Bulkley, R.V., Berry, C.R., Pimentel, R., and Black T., 1981, Tolerance and preferences of Colorado River endangered fishes to selected habitat parameters: Utah Cooperative Fisheries 
Research Unit, Utah State University, completion report for the U.S. Fish and Wildlife Service, contract 14-16-00018-1061 A-2, 56 p.

Carothers, S.W., and Brown, B.T., 1991, The Colorado River through Grand Canyon-natural history and human change: Tucson, University of Arizona Press, 235 p.

Clarkson, R.W., and Childs, M.R., 2000, Temperature effects of hypolimnial-release dams on early life stages of Colorado River Basin big-river fishes: Copeia, v. 2000, no. 2, p. 402-412, accessed on August 19, 2011 at http://www.bioone.org/doi/abs/10.1643/0045-

8511(2000)000\%5B0402\%3ATEOHRD\%5D2.0.CO\%3B2.

Converse, Y.K., Hawkins, C.P., and Valdez, R.A., 1998, Habitat relationships of subadult humpback chub in the Colorado River through Grand Canyon--spatial variability and implications of flow regulation: Regulated Rivers-Research and Management, v. 14, no. 3, p. 267-284, accessed on October 14, 2010, at http://onlinelibrary.wiley.com/doi/10.1002/(SICI)1099-1646(199805/06)14:3\%3C267::AIDRRR501\%3E3.0.CO;2-5/abstract.

Davis, P.A., 2002. Evaluation of airborne thermal-infrared image data for monitoring aquatic habitats and cultural resources within the Grand Canyon: U.S. Geological Survey Open-File Report 02-367, 49 p.

Freeman, M.C., Bowen Z.H., Bovee, K.D., Irwin, E.R., 2001, Flow and habitat effects on juvenile fish abundance in natural and altered flow regimes: Ecological Applications, v. 11, no. 1, p. 179-190, accessed on August 19, 2011, at http://www.jstor.org/stable/3061065.

Goeking, S.A., Schmidt, J.C., and Webb, M.K., 2003, Spatial and temporal trends in the size and number of backwaters between 1935 and 2000, Marble and Grand Canyons, Arizona-final report: U.S. Geological Survey, Grand Canyon Monitoring and Research Center and Utah State University, Department of Aquatic, Watershed and Earth Resources, cooperative agreement no. 01WRAG0059, 26 p. [Available upon request by contacting the Center Director, U.S. Geological Survey, Southwest Biological Science Center, 2255 N. Gemini Drive, Flagstaff, Ariz. 86001.]

Gorman, O.T., and Stone, D.M., 1999, Ecology of spawning humpback chub, Gila cypha, in the Little Colorado River near Grand Canyon, Arizona: Environmental Biology of Fishes, v. 55, no. 1-2, p. 115-133, accessed on February 12, 2010, at http://www.springerlink.com/content/vq675171n84786p7/.

Hazel, J.E., Jr., Topping, D.J., Schmidt, J.C., and Kaplinski, M., 2006, Influence of a dam on fine-sediment storage in a canyon river: Journal of Geophysical Research, v. 111, no. F01025, p. 1-16, accessed on December 28, 2009, at http://www.agu.org/journals/jf/jf0601/2004JF000193/2004JF000193.pdf.

Johnstone, H.C., and Lauretta, M.V., 2006, Native fish monitoring activities in the Colorado River with Grand Canyon during 2004 — draft report: Flagstaff, Ariz., SWCA, Inc. Environmental Consultants, submitted to U.S. Geological Survey, Grand Canyon Monitoring and Research Center, 122 p. [Available upon request by contacting the Center Director, U.S. Geological Survey, Southwest Biological Science Center, 2255 N. Gemini Drive, Flagstaff, Ariz. 86001.]

Korman, J., and Campana, S.E., 2009, Effects of hydropeaking on nearshore habitat use and growth of age-0 rainbow trout in a large regulated river: Transactions of the American Fisheries Society, v. 138, no. 1, p. 76-87, accessed on June 1, 2011, at http://www.tandfonline.com/doi/abs/10.1577/T08-026.1.

Korman, J., Kaplinski, M., and Buszowski, J., 2006, Effects of air and mainstem water temperatures, hydraulic isolation, and fluctuating flows from Glen Canyon Dam on water 
temperatures in shoreline environments of the Colorado River in Grand Canyon-final report: Ecometric Inc., submitted to U.S. Geological Survey, Grand Canyon Monitoring and Research Center, 57 p. [Available upon request by contacting the Center Director, U.S. Geological Survey, Southwest Biological Science Center, 2255 N. Gemini Drive, Flagstaff, Ariz. 86001.]

Korman, J., Wiele, S.M., and Torizzo, M., 2004, Modelling effects of discharge on habitat quality and dispersal of juvenile humpback chub (Gila cypha) in the Colorado River, Grand Canyon: River Research and Applications, v. 20, no. 4, p. 379-400, accessed on February 22, 2010, at http://www3.interscience.wiley.com/cgi-bin/fulltext/107614374/PDFSTART.

McGuinn-Robbins, D.K., 1995, Comparison of the number and area of backwaters associated with the Colorado River in Glen, Marble and Grand Canyons, Arizona - draft report: Arizona Game and Fish Department, submitted to Bureau of Reclamation, Glen Canyon Environmental Studies, contract no. 9-FC-40-07940, 26 p. [Available upon request by contacting the Center Director, U.S. Geological Survey, Southwest Biological Science Center, 2255 N. Gemini Drive, Flagstaff, Ariz. 86001.]

Protiva, F.R., Ralston, B.E., Stone, D.M., Kohl, K.A., Yard, M.D., and Haden, G.A., 2010, Effects of Glen Canyon Dam discharges on water velocity and temperatures at the confluence of the Colorado and Little Colorado Rivers and implications for habitat for young-of-year humpback chub (Gila cypha): U.S. Geological Survey Open-File Report 2010-1137, 24 p., accessed on July 27, 2010, at http://pubs.usgs.gov/of/2010/1137/.

Ralston, B.E., Lauretta, M.V., Kennedy, T.A., 2007, Comparisons of water quality and biological variables from Colorado River shoreline habitats in Grand Canyon, Arizona, under steady and fluctuating discharges from Glen Canyon Dam: U.S. Geological Survey Open File Report 2007-1195, accessed on August 19, 2011, at http://pubs.usgs.gov/of/2007/1195/.

Robinson, A.T., Clarkson, R.W., and Forrest, R.E., 1998, Dispersal of larval fishes in a regulated river tributary: Transactions of the American Fisheries Society, v. 127, no. 5, p. 772-786, accessed on Jun 1, 2011, at http://www.tandfonline.com/doi/abs/10.1577/15488659\%281998\%29127\%3C0772\%3ADOLFIA\%3E2.0.CO\%3B2.

Rubin, D.M., Schmidt, J.C., and Moore, J.N., 1990, Origin, structure, and evolution of a reattachment bar, Colorado River, Grand Canyon, Arizona: Journal of Sedimentary Petrology, v. 60 , no. 6 , p. 982-991, accessed on January 12, 2010, at http://walrus.wr.usgs.gov/reports/reprints/Rubin_JSP_60.pdf.

Rubin, D.M., Topping, D.J., Schmidt, J.C., Hazel, J., Kaplinski, M., and Melis, T.S., 2002, Recent sediment studies refute Glen Canyon Dam hypothesis: Eos Transactions, American Geophysical Union, v. 83, no. 25, p. 273, 277-278.

Schmidt, J.C., and Rubin, D.M., 1995, Regulated stream-flow, fine-grained deposits, and effective discharge in canyons with abundant debris fans, in Costa, J.E., Miller, A.J., Potter, K.W., and Wilcock, P.R., eds., Natural and anthropogenic influences in fluvial geomorphology, v. 89: Washington, D.C., American Geophysical Union, Geophysical Monograph Series, p. 177-195.

Schmidt, J.C., Topping, D.J., Grams, P.E., and Hazel, J.E., Jr., 2004, System-wide changes in the distribution of fine sediment in the Colorado River corridor between Glen Canyon Dam and Bright Angel Creek, Arizona - final report: Logan, Utah, submitted to U.S. Geological Survey, Grand Canyon Monitoring and Research Center, cooperative agreement no. 1425-98-FC-4022640, $107 \mathrm{p}$.

Schmidt, J.C., Topping, D.J., Rubin, D.M., Hazel, J.E., Jr., Kaplinski, M., Wiele, S.M., and Goeking, S.A., 2007, Streamflow and sediment data collected to determine the effects of low summer steady flows and habitual maintenance flows in 2000 on the Colorado River between 
Lees Ferry and Bright Angel Creek, Arizona: U.S. Geological Survey Open-File Report 20071268, 79 p., accessed on March 17, 2010, at http://pubs.usgs.gov/of/2007/1268/.

Topping, D.J., Rubin, D.M., Nelson, J.M., and Kinzel, P.J., 2000a, Colorado River sediment transport 2-systematic bed-elevation and grain-size effects of supply limitation: Water Resources Research, v. 36, no. 2, p. 543-570.

Topping, D.J., Rubin, D.M., and Vierra, L.E., Jr., 2000b, Colorado River sediment transport, pt. 1 -natural sediment supply limitation and the influence of the Glen Canyon Dam: Water Resources Research, v. 36, no. 2, p. 515-542.

Topping, D.J., Rubin, D.M., Schmidt, J.C., Hazel, J.E., Jr., Melis, T.S., Wright, S.A., Kaplinski, M., Draut, A.E., and Breedlove, M.J., 2006, Comparison of sediment-transport and barresponse results from the 1996 and 2004 controlled-flood experiments on the Colorado River in Grand Canyon, in Federal Interagency Sedimentation Conference, 8th, Reno, Nev., April 26, 2006, Proceedings: p. 8 (CD-ROM).

Topping, D.J., Schmidt, J.C., and Vierra, L.E., 2003, Computation and analysis of the instantaneous-discharge record for the Colorado River at Lees Ferry, Arizona-May 8, 1921, through September 30, 2000: U.S. Geological Survey Professional Paper 1677, 118 p., accessed on January 28, 2010, at http://pubs.usgs.gov/pp/pp1677/pdf/pp1677.pdf.

U.S. Geological Survey, 1999, Final report of the physical resources monitoring peer review panel-Protocols Evaluation Program (PEP - SEDS): Flagstaff, Ariz., U.S. Geological Survey, Grand Canyon Monitoring and Research Center, 13 p.

U.S. Geological Survey, 2010, National Water Information System (NWISWeb): U.S. Geological Survey database, accessed April 27, 2010, at http://waterdata.usgs.gov/nwis.

Valdez, R.A., and Carothers, S.W., 1998, The aquatic ecosystem of the Colorado River in Grand Canyon-Grand Canyon data integration synthesis final report: Flagstaff, Ariz., SWCA, Inc. Environmental Consultants, submitted to Bureau of Reclamation, 250 p. [Available upon request by contacting the Center Director, U.S. Geological Survey, Southwest Biological Science Center, 2255 N. Gemini Drive, Flagstaff, Ariz. 86001.]

Valdez, R.A., Carothers, S.W., House, D.A., Douglas, M.E., Ryel, R.J., Bestgen, K.R., and Wegner, D.L., 2000, A program of experimental flows for endangered and native fishes of the Colorado River in Grand Canyon-final report: Flagstaff, Ariz., SWCA, Inc. Environmental Consultants, submitted to U.S. Geological Survey, Grand Canyon Monitoring and Research Center, 68 p. [Available upon request by contacting the Center Director, U.S. Geological Survey, Southwest Biological Science Center, 2255 N. Gemini Drive, Flagstaff, Ariz. 86001.]

Valdez, R.A., and Ryel, R.J., 1995, Life history and ecology of the humpback chub (Gila cypha) in the Colorado River, Grand Canyon, Arizona - final report: Logan, Utah, BIO/WEST, Inc., submitted to Bureau of Reclamation, contract no. 0-CS-40-09110, technical report no. TR250-08, 329 p. [Available upon request by contacting the Center Director, U.S. Geological Survey, Southwest Biological Science Center, 2255 N. Gemini Drive, Flagstaff, Ariz. 86001.] Vernieu, W.S., Hueftle, S.J., and Gloss, S.P., 2005, Water quality in Lake Powell and the Colorado River, in Gloss, S.P., Lovich, J.E., and Melis, T.S., eds., The state of the Colorado River ecosystem in Grand Canyon: U.S. Geological Survey Circular 1282, 69-85 p., accessed on May 10, 2010, at http://pubs.usgs.gov/circ/1282/.

Voichick, N., and Wright, S.A., 2007, Water-temperature data for the Colorado River and tributaries between Glen Canyon Dam and Spencer Canyon, Northern Arizona, 1988-2005: U.S. Geological Survey Data Survey Series 251, 24 p., accessed on January 14, 2010, at http://pubs.usgs.gov/ds/2007/251/. 
Wright, S.A., Anderson, C.R., and Voichick, N., 2008, A simplified water temperature model for the Colorado River below Glen Canyon Dam: River Research and Applications, v. 25, no. 6, p. 675-686, accessed on August 19, 2011, at http://dx.doi.org/10.1002/rra.1179.

Wright, S.A., and Kennedy, T.A., 2011, Science-based strategies for future high-flow experiments at Glen Canyon Dam, in Melis, T.S., ed., Effects of three high-flow experiments on the Colorado River ecosystem downstream from Glen Canyon Dam, Arizona: U.S. Geological Survey Circular 1366, p. 127-147.

Wright, S.A., Schmidt, J.C., Melis, T.S., Topping, D.J., and Rubin, D.M., 2008, Is there enough sand? Evaluating the fate of Grand Canyon sandbars: Geological Society of America Today, v. 18 , no. 8, p. 4-10, accessed on May 26, 2010, at http://www.geosociety.org/gsatoday/archive/18/8/pdf/i1052-5173-18-8-4.pdf.

Yard, M.D., Bennett, G.E., Mietz, S.N., Coggins, L.G., Jr., Stevens, L.E., Hueftle, S.J., and Blinn, D.W., 2005, Influence of topographic complexity on solar insolation estimates for the Colorado River, Grand Canyon, AZ: Ecological Modelling, v. 183, no. 2-3, p. 157-172, accessed on July 19, 2011, at http://www.sciencedirect.com/science/article/pii/S0304380004004375. 


\section{Chapter 3. Native and Nonnative Fish Response to the Steady Summer Flow Experiment in the Mainstem Downstream from Lees Ferry}

\section{Introduction}

The purpose of the Low Steady Summer Flow (LSSF) experiment was to determine if reduced discharge and steady flows would improve mainstem spawning success and increase growth of young native fish through improved nursery habitats and warmer water. The previous section described how the discharge rates and initial release temperatures affect the warming potential and water velocities in the mainstem and along shorelines. These variables translate to suitable and sustained aquatic environments that young fish can occupy. The young fish use these environments in the summer months after migrating from the tributaries, either as drifting larvae, or as young-of-year (YOY) fish transported with tributary freshets. Korman and others (2004) and Protiva and others (2010) quantified the effects of discharge on shoreline velocities and the extent of available and sustained low-velocity areas that young native fish can occupy at the confluence with the Little Colorado River and downstream from the confluence along the shorelines of the mainstem (fig. 3-1). If mainstem and shoreline water temperatures reached optimum rearing temperatures of $15^{\circ} \mathrm{C}$ or greater, an anticipated response of fish was a shift in fish-length frequency toward larger sized YOY fish compared with previous years. An increase in the abundance of fish also could be a response to warmer water.

Critical to understanding the fish response is data collected before, during, and following the hydrologic treatment as identified by Valdez and others (unpub. report, 2000). During Period I, few biological data related to larval drift and ponding were collected. During Period II, three mainstem trips that included seining, trammel netting, and electroshocking were conducted in June, August, and September. Trammel and others (unpub. report, 2002) and Speas and others (unpub. report, 2004) documented changes in mean total fish length and the relative abundance of species during Period II. Data collected before implementation of the experimental hydrograph were not focused on long-term monitoring; instead, data were collected in association with life-history studies of humpback chub (Valdez and Ryel, unpub. report, 1995) or opportunistic sampling of backwater habitats (Arizona Game and Fish, unpub. report, 1996). Lacking long-term historical data of mainstem trends for native and nonnative fish hampers interpretation of the effects on fish of the 1-year hydrologic treatment. The results reported for 2000 are discussed in the context of the historical data, hydrology, and sampling effort to assist in interpreting the growth and abundance results observed in 2000. Hydrology that benefits native fish also was likely to benefit nonnative fish. Efforts to ameliorate the potential positive response by nonnative fish to the experiment included the 4-day habitat maintenance flow (HMF) at the beginning of September (fig. 1-4), which was intended to displace small-bodied nonnative fish (for example, fathead minnows (Pimephales promelas) and red shiners). A discussion of the utility of the ponding flows in the spring and the utility and uncertainties that the September HMF added to the interpretation of the young fish response is included in this section. 


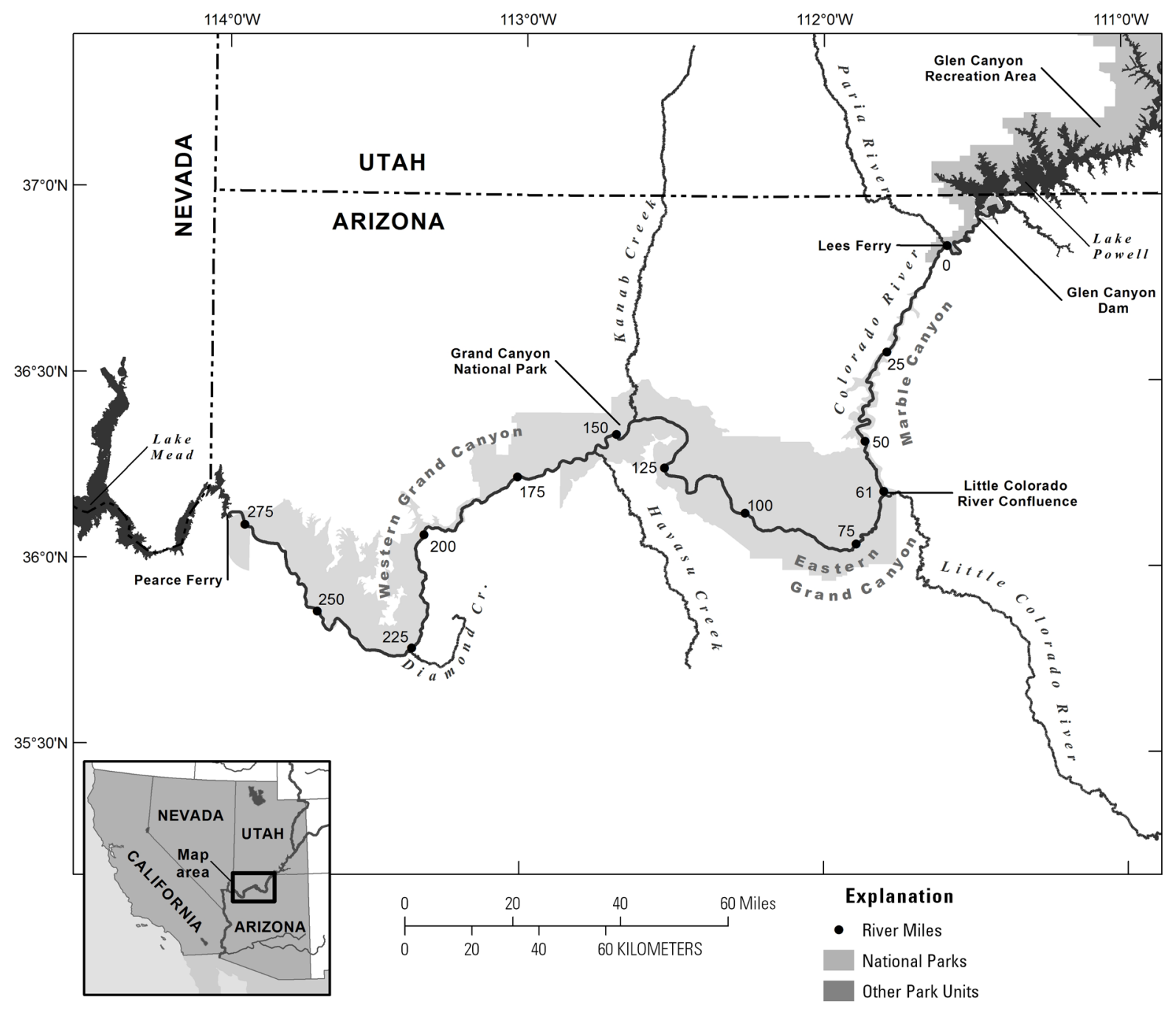

Figure 3-1. Map of the Colorado River downstream from Glen Canyon Dam. River mile (RM) designations occur at 25-mile intervals starting from Lees Ferry, designated as RM 0 . Large tributaries to the mainstem, including the Little Colorado River, are identified.

\section{Period I: Tributary Ponding}

Tributary ponding was predicted to improve larval survival of all native fish, but tributary ponding may benefit native sucker species more than humpback chub (Gila cypha) (Robinson and others, 1998). Robinson and others (1998) reported large numbers of drifting bluehead sucker (Catostomus discobolus) and flannelmouth sucker (Catostomus latipinnis) larvae, but few numbers of humpback chub larvae drifting into the mainstem from the Little Colorado River (LCR) during the months of May through July. Instead, they report that humpback chub largely remain close to spawning sites. YOY humpback chub appear to enter the mainstem in association with monsoon storms that occur in July through September (Valdez and Ryel, unpub. report, 1995). The small numbers of drifting humpback chub larvae observed by Robinson and others (1998) and their observations that chub remain close to spawning sites suggest that 
ponding using high flows in the spring may have had little measurable benefit for larval humpback chub survivorship. The negligible benefit of ponding is further called into question when the mainstem and LCR flow dynamics under high mainstem volumes reduce low-velocity, warmwater areas (Protiva and others, 2010; figs. 2-4, 2-5). In contrast, larvae that drifted toward the confluence area of the mainstem in June through August might have benefitted from the lower mainstem discharge of $226 \mathrm{~m}^{3} / \mathrm{s}$. At this lower discharge, the area of warmer and lowervelocity water at the confluence increases (Protiva and others, 2010; figs. 8 and 9) when LCR flows are at base-flow levels.

\section{Period II: Fish Growth and Abundance during Steady Minimal Discharges}

Trammell and others (unpub. report, 2002) compared the 2000 YOY fish abundance and mean total lengths of fish caught in seines with previous years (1991-97) to see if these variables differed during steady flow and Modified Low Fluctuating Flow (MLFF) operations. Sampling with seines, primarily used in backwaters, during the LSSF experiment occurred June 7-23, shortly after the spring HMF; August 6-22, about halfway through Period II; and September 1429, a week following the fall HMF (Trammell and others, unpub. report, 2002). The data collected by Trammel and others (unpub. report, 2002) are presented here with geographic separation of sample sites upstream and downstream from river mile (RM) 150 (figs. 3-2 A, B; 3$3 A, B)$. Mainstem water temperatures were at or above the optimal rearing temperature for humpback chub $\left(15^{\circ} \mathrm{C}\right)$ by May 2000 at sites downstream from RM 150 (Voichick and Wright, 2007; fig. 2.8) and may have affected growth or abundance patterns of YOY fish in 2000.

Trammell and others (unpub. report, 2002) noted that relative abundance of native fish was greater than nonnative fish caught in seines in the eastern and western parts of Grand Canyon, except upstream from RM 150 in September (figs. 3-2 A,B). Among native fish species sampled in June 2000, flannelmouth suckers and speckled dace (Rhinichthys osculus) were the most frequently encountered native fish upstream and downstream from RM 150, respectively (figs. 3-3 $A, B$ ). The relative abundance of humpback chub was minimal in backwaters upstream and downstream from RM 150 throughout the sampling period (figs. 3-3 $A, B$ ). Grams and others (2010) also documented minimal abundances of humpback chub in a more recent backwater study conducted in 2008 and 2009. The abundances Grams and others (2010) indicated for humpback chub in 2008 and 2009 were small even in light of increased numbers for this species since 2000 (Coggins and Walters, 2009), possibly indicating that humpback chub occupy other shoreline environments besides backwaters, as identified by Converse and others (1998). 


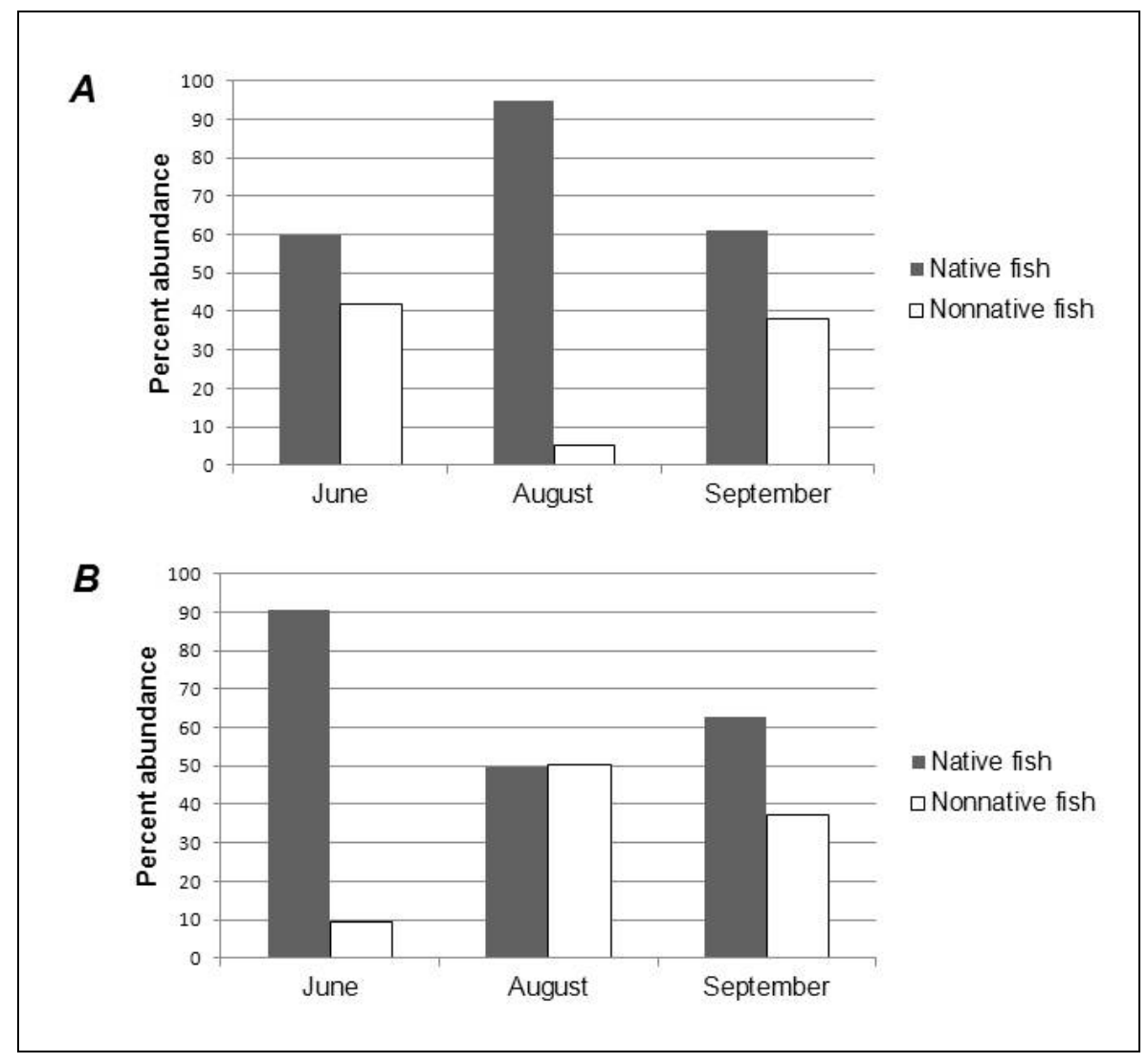

Figure 3-2. Bar graphs showing relative abundance of native and native fish species with total lengths less than $110 \mathrm{~mm}$ collected $(A)$ upstream and $(B)$ downstream from river mile 150, June 7-23, August 622, and September 14-29, 2000 (data from Trammell and others, unpub. report, 2002). 


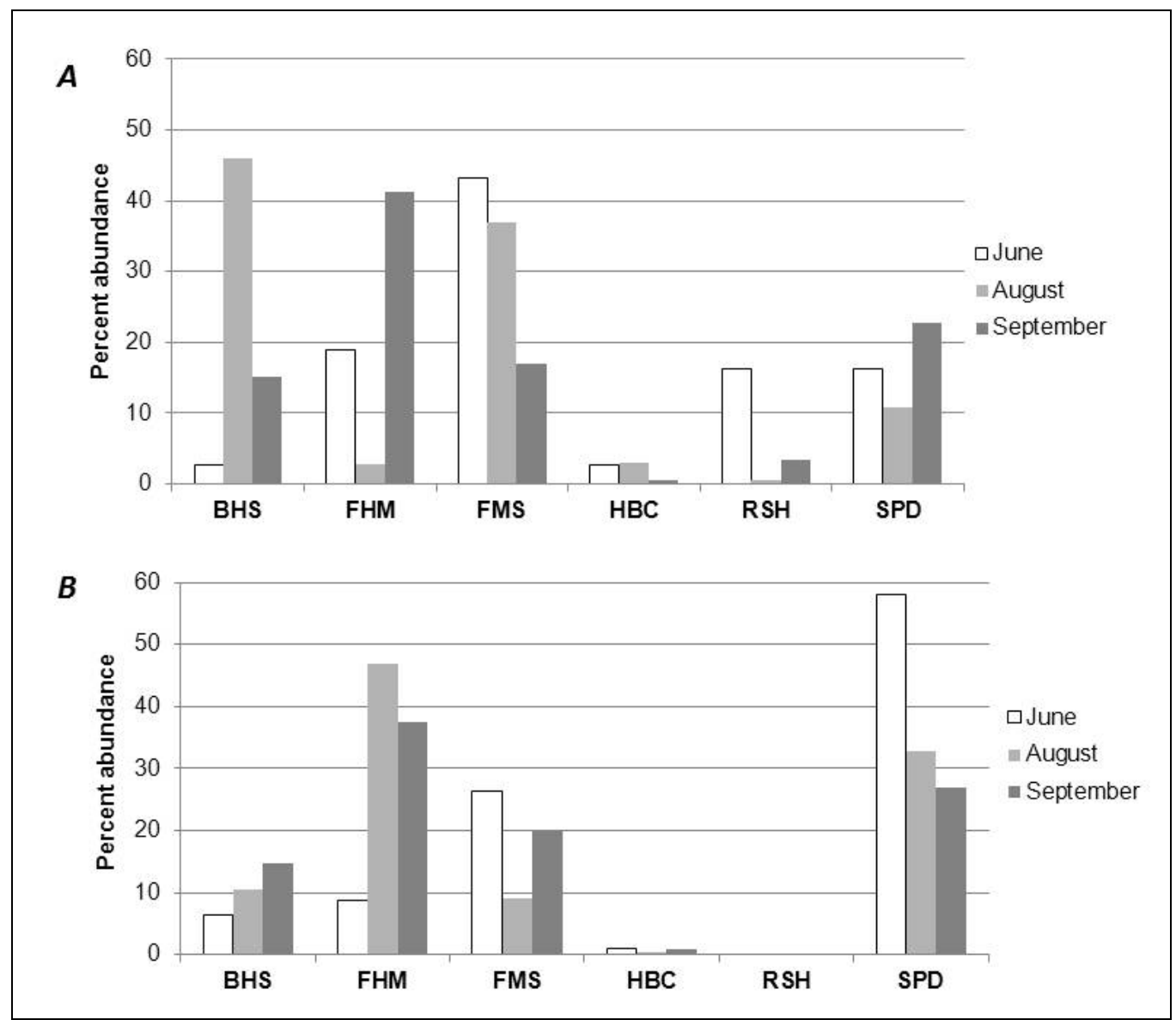

Figure 3-3. Bar graphs showing relative abundance of the six most abundant fish species with total lengths less than $110 \mathrm{~mm}$ collected $(A)$ upstream and $(B)$ downstream from river mile 150, June 7-23, August 6-22, and September 14-29, 2000 (data from Trammell and others, unpub. report, 2002). Abbreviations along horizontal axis are BHS (bluehead sucker), FHM (fathead minnow), FMS (flannelmouth sucker), HBC (humpback chub), RSH (red shiner), and SPD (speckled dace).

Mean total length of the six most abundant fish species in 2000 did not differ from previous years (Trammell and others, unpub. report, 2002). Fish-length data from 2000 are difficult to interpret because the sampling included seining data after the September HMF, and mainstem water temperatures met optimal rearing requirements of native fish in the western Grand Canyon, but not in the eastern Grand Canyon (the mainstem near the LCR). Trammell and others (unpub. report, 2002) reported larger humpback chub caught near the LCR in 2000 compared to humpback chub located farther downstream (figs. 3-4 A, B). The authors attributed the longer lengths of fish caught downstream from the LCR (RM 61-75; fig. 3-4A) to fish entering the mainstem from the LCR tributary, where conditions for growth were better. Comparisons of mean total length in 2000 with data from 1991-97 for August and September indicated that mean lengths for 2000 were less than in previous years (Trammell and others, unpub. report, 2002). The smaller fishes observed in 2000 were attributed to protracted spawning in the mainstem and the continuous influx of larvae and small fish into backwaters (Trammell and others, unpub. report, 2002), particularly in the western Grand Canyon (fig. 3-4B). The abundances of fish in backwaters was greater in 2000 compared with previous years. The HMF 
likely displaced some fish occupying backwaters and by September fish longer than $100 \mathrm{~mm}$ may have moved from backwaters. Trammell and others (unpub. report, 2002) concluded that steady flows did not appear to result in increased fish growth. This conclusion should be viewed cautiously, however, because it is based on only 1 year of data that included the effects of a HMF. In addition, the data were collected with a single gear type that does not sample all the shoreline environments that YOY may occupy.

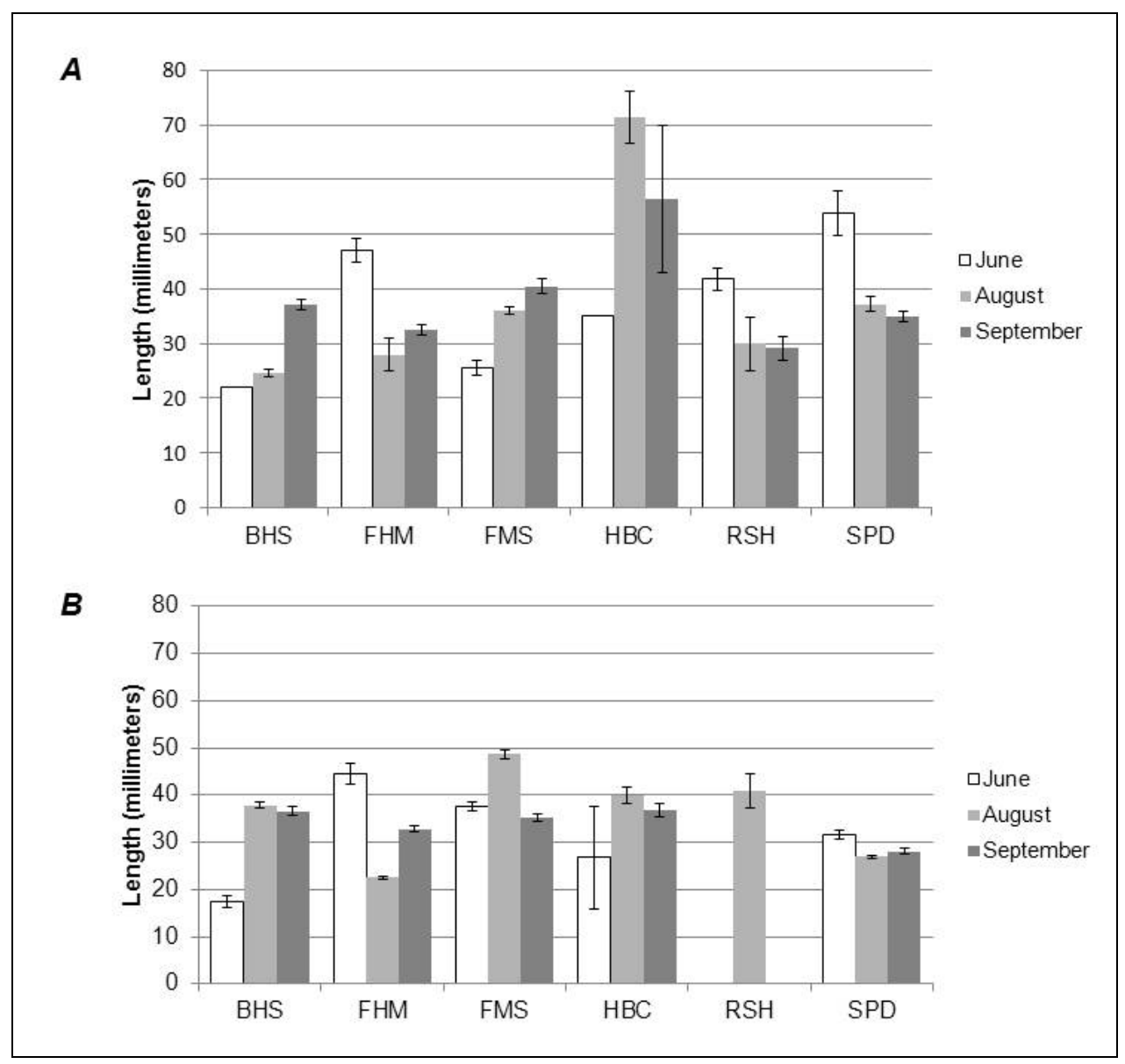

Figure 3-4. Bar graphs showing mean fish length (total length) of the six most common fish species with lengths less than $110 \mathrm{~mm}$ collected $(A)$ upstream and $(B)$ downstream from river mile 150, June 7-23, August 6-22, and September 14-29, 2000. Error bars represent one standard error (data from Trammell and others, unpub. report, 2002). Abbreviations along horizontal axis are BHS (bluehead sucker), FHM (fathead minnow), FMS (flannelmouth sucker), HBC (humpback chub), RSH (red shiner), and SPD (speckled dace).

\section{Nonnative Response to Steady Flows and Warmer Water}

Resource competition and native fish predation by nonnative fish are threats to the native fish recruitment in the Colorado River in Grand Canyon (Minckley, 1991; Gloss and Coggins, 2005; Yard and others, 2011). The relative abundance of small-sized nonnative fish remained smaller than those of native fish throughout the summer (figs. 3-2 $A$, $B$ ). The greater percentage of native small-sized fish was associated with greater abundance of speckled dace earlier in the 
summer followed by increased abundances of flannelmouth and bluehead suckers in August and September (figs. 3-3 $A, B$ ). Trammell and others (unpub. report, 2002) compared relative abundance of nonnative fish captured in seines in 2000 with previous years (1990-97) and determined there was no difference among years. Subsequent years, 2002-6, also did not indicate substantial differences in YOY abundances for all fish combined (Ackerman, unpub. report, 2008).

Three nonnative fish - fathead minnows (Pimephales promelas), plains killifish (Fundulus zebrinus), and rainbow trout (Oncorhynchus mykiss) - appeared to benefit from either the reduced fluctuations, warmer water temperatures, or both. McKinney and others (2001) and Korman and others (2011) documented the benefit of reduced flows associated with MLFF operations on rainbow trout spawning and recruitment in the Lees Ferry fishery (fig. 3-1). Speas and others (unpub. report, 2004) reported a large increase in rainbow trout with lengths less than $120 \mathrm{~mm}$ in Lees Ferry in summer 2000, but did not see a corresponding large recruitment into the next size class in 2001. Fathead minnows caught in the western Grand Canyon (RM 160219) were most abundant in 2000 compared to subsequent years (Johnstone and Lauretta, unpub. report, 2004), suggesting that steady flows may benefit this species. Plains killifish catch rates increased beginning in 2002 for nearly every reach (Johnstone and Lauretta, unpub. report, 2004). This species did not constitute a large percentage of the fish captured in 2000.

A part of the LSSF experiment specifically included developing abundance estimates for rainbow and brown trout (Salmo trutta) in the Colorado River mainstem and developing monitoring approaches for nonnative fish in the mainstem (Speas and others, unpub. report, 2004). Data from the Arizona Game and Fish Department (Makinster and others, 2010) indicate that abundances of adult rainbow and brown trout during 2000-9 were either at or approached a maximum in 2000. No abundance estimates are available for these species before 2000 . Because of predation by rainbow and brown trout, the large abundance of these fish in the mainstem likely affected the abundance of native and small-bodied nonnative fish in 2000, particularly near the confluence with the LCR (Yard and others, 2011).

\section{Habitat Maintenance Flows for the Purpose of Disadvantaging Nonnative Fish}

The purpose of the second HMF, conducted in September 2000, was to disadvantage nonnative fish (Valdez and others, unpub. report, 2000; table 1). Minckley and Meffe (1987) documented that flood events affected nonnative fish more negatively than native fish in a small stream in the Southwest. More recently, Korman (2009) indicated that the 2004 fall high-flow experiment (HFE) displaced young rainbow trout in Glen Canyon, though the fate of these fish is unknown. A comparison of the relative abundance of native and nonnative fish in August and September 2000 indicated that the relative abundance of nonnative fish was larger in September upstream of RM 150 than in August (fig. 3-2; Trammell and others, unpub. report, 2002). This suggests that the September HMF did not have the expected effect on small-sized nonnative fish. The reasons for the response difference between the small streams studied by Minckley and Meffe (1987) and the larger Colorado River are not known. One explanation may be that the river scales may not be directly comparable and the expected effects may be unquantifiable in a large river. Nonnative fish abundance increased upstream from RM 150 following the HMF (fig. 3-3A) and Trammell and others (unpub. report, 2002) noted an increase between RM 60 and 80. Increased abundances of nonnative fish moving into the mainstem during freshets in the LCR, Havasu Creek, and Kanab Creek tributaries (fig. 3-1) in September may explain the observed 
increases in nonnative species. Speas and others (unpub. report, 2004) determined that the HMF did not affect the fish-length frequencies of downstream YOY rainbow and brown trout. Because of the uncertainty of how the HMF affected native fish and because small-sized nonnative fish abundance was less than native fish before the HMF (fig. 3-2), research in conjunction with a fall HMF might improve knowledge about native and nonnative fish responses to these below powerplant-capacity pulses.

\section{Factors Affecting Interpretations of Fish Abundance and Growth}

Assessing changes in length frequency of small fish based on seining is problematic; seining samples backwaters effectively but does not sample other shorelines and captures fish that average $51 \mathrm{~mm}$, rather than a range of lengths. Converse and others (1998) found that humpback chub less than $200 \mathrm{~mm}$ long use shorelines other than backwaters (for example, vegetated shorelines or talus). Slow electroshocking (for example, shocking along shorelines at a slow rate) from a boat may be a sampling method for small fish along shorelines other than backwaters. The LSSF data for small-sized fish captured using seining have a limited ability to determine the fate of fish that grow beyond $110 \mathrm{~mm}$ length or occupy areas other than backwaters.

Drawing conclusions about fish growth in 2000 compared to previous years also is problematic. Fish abundances, particularly native fish abundances, were small in the 1990s (Douglas and Marsh, 1996), and the monthly discharges in the summer, when fish were sampled, were variable and generally greater than in 2000 . Although Trammell and others (unpub. report, 2002) correctly point out that daily fluctuations in the 1990s were similar, they failed to note that monthly discharges between years varied. The monthly discharges in July and August 1991-93 were relatively low $\left(<368 \mathrm{~m}^{3} / \mathrm{s}\right)$, whereas the discharges were higher $\left(>424 \mathrm{~m}^{3} / \mathrm{s}\right)$ for these same months in 1994-96. The discharge rate can affect the catchability of small fish (Korman and others, 2009) and availability of shoreline habitats (Converse and others, 1998; Korman and others, 2004; Korman and others, 2009), thereby affecting abundance and size distribution of fish caught. The higher monthly discharges in the late 1990s may have favored larger fish that could withstand higher-velocity shorelines. The greater mean lengths reported by Trammell and others (unpub. report, 2002) for fish caught in the 1990s may be an indication of these sampling biases and merit further exploration. Lastly, the seining locations varied among the years that were compared. In some years, seining efforts focused near the LCR, whereas in other years more extensive sampling occurred throughout the river corridor (U.S. Geological Survey, unpub. data, 2009). Trammell and others (unpub. report, 2002) reported larger humpback chub near the LCR in 2000 compared to locations farther downstream. The effect of the larger YOY fish entering the mainstem from the LCR is another example of how previous sampling efforts can confound interpretations of a single-season experiment. In years when sampling focused near the LCR, mean total length of native fish may be greater than in years when sampling occurred throughout the river corridor. The variability in sampling locations in the 1990s lends further uncertainty to the meaning of fish lengths measured under steady-flow conditions in 2000 relative to those measured during fluctuating-flow conditions in other years. These findings underscore the need for consistent methods and timing of monitoring. 


\section{Conclusions}

Variables associated with gear types used to catch fish, fish life history, rarity of fish, and the experimental hydrograph contributed to uncertainties associated with fish response to the experimental hydrograph of Period II. Ontogenetic shifts (for example, changes in diet and habitat use) associated with growth can cause fish to move out of one habitat and into another (Robinson and others, 1998; Stone and Gorman, 2006). Gear types that sample one habitat but do not effectively sample other habitats result in less than accurate sampling of fish. Korman and Campana (2009) demonstrated that as YOY rainbow trout grow in the Glen Canyon reach of the Colorado River, they shift away from shallow, low-angle habitats to environments with deeper water. Similarly, Stone and Gorman (2006) documented that as they grow, young native fish in the LCR shift from shorelines to open channels during daylight hours. Seines used in backwaters capture fish that are most often less than $110 \mathrm{~mm}$ in length (Ackerman, unpub. report, 2008). The limitation of a seine to catch fish longer than $110 \mathrm{~mm}$ and fish occupying habitats other than backwaters precludes knowing the fate of the fish once they reach a size where they are either less vulnerable to seining or have switched habitat from a backwater to another shoreline type. Trammell and others (unpub. report, 2002) indicate that the number of fish captured with different gear types during the same months in different years were insufficient to document an ontogenetic shift. The rarity of native fish, the abundance of shoreline types other than backwaters, and the limitations of different gear types (for example, trammel nets only work in eddy environments) further obscure information on fish abundance and length frequencies in response to the experimental treatment.

The potential for predation of native fish by the brown and rainbow trout, which were abundant in the mainstem in 2000 (Makinster and others, 2010), further confounded assessment of the experimental effects on YOY native fish. The large numbers of brown and rainbow trout detected in the mainstem in 2000 were sufficient for resource managers to decide to implement mechanical removal of these species from the mainstem near the LCR in 2003-6 as an experiment to improve native fish recruitment (Gloss and Coggins, 2005; Coggins, 2008; Coggins and others, 2011). In association with the mechanical removal experiment, Yard and others (2011) demonstrated that greater abundances of brown and rainbow trout result in predation of small-sized fish, including native fish, and that water clarity affects rates of predation. In 2000, high levels of water clarity existed in the system for much of the summer because of a lack of tributary inputs (Schmidt and others, 2007). Yard and others (2011) determined that in the absence of fish suppression brown and rainbow trout could consume as many as 45,000 native fish per year. The high abundance of adult brown and rainbow trout in the mainstem and the high water clarity throughout the river corridor in the summer of 2000 might have contributed to higher predation rates on native fish near the LCR and possibly affected mean length data collected in 2000 (Trammell and others, unpub. report, 2002).

Lastly, the HMF in the middle of Period II likely contributed to inconclusive results by displacing some small fish, including native fish, through habitat reworking and increased shoreline velocities. The HMF changed habitat that had been persistent for 3 months (Schmidt and others, 2007). Further, the September HMF was similar to dam operations until the 1990s. The Operation of Glen Canyon Dam Final Environmental Impact Statement (U.S. Department of the Interior, 1995) concluded that high, fluctuating flows were detrimental to native fish. Korman and Campana (2009) determined that young rainbow trout stay in habitats that persist at the daily minimum flow levels during MLFF operations instead of moving up and down the water column 
with the daily fluctuations. The young trout remain in place, presumably, to conserve energy and avoid predators. The same behavioral pattern might apply to YOY native fish. Warmer mainstem temperatures, achievable under lower reservoir elevations, may be more critical to fish growth and survival than stable shorelines that only achieve rearing temperatures during part of the day. Additional work may clarify how discharge patterns, shoreline warming, the locations of young fish within the river channel, and daily variation in temperature along shorelines relate to fish growth and movement.

\section{References}

Ackerman, M.W., 2008, 2006 native fish monitoring activities in the Colorado River, Grand Canyon: Flagstaff, Ariz., SWCA, Inc. Environmental Consultants, submitted to Grand Canyon Monitoring and Research Center, cooperative agreement 04WRAG0011. [Available upon request by contacting the Center Director, U.S. Geological Survey, Southwest Biological Science Center, 2255 N. Gemini Drive, Flagstaff, Ariz. 86001.]

Arizona Game and Fish Department, 1996, Ecology of Grand Canyon backwaters-final report: Phoenix, Ariz., submitted to Bureau of Reclamation, Glen Canyon Environmental Studies, cooperative agreement no. 9-FC-40-07940, 155 p. [Available upon request by contacting the Center Director, U.S. Geological Survey, Southwest Biological Science Center, 2255 N.

Gemini Drive, Flagstaff, Ariz. 86001.]

Coggins, L.G., Jr., 2008, Active adaptive management for native fish conservation in the Grand Canyon-implementation and evaluation: Gainseville, University of Florida, Ph.D. dissertation, $174 \mathrm{p}$.

Coggins, L.G., Jr., and Walters, C.J., 2009, Abundance trends and status of the Little Colorado River population of humpback chub - an update considering data from 1989-2008: U.S. Geological Survey Open-File Report 2009-1075, 18 p., accessed on August 19, 2011, at http://pubs.usgs.gov/of/2009/1075/.

Coggins, L.G., Yard, M.D., and Pine, W.E., 2011, Nonnative fish control in the Colorado River in Grand Canyon, Arizona--an effective program or serendipitous timing?: Transactions of the American Fisheries Society, v. 140, no. 2, p. 456-470, accessed on July 29, 2011, at http://www.tandfonline.com/doi/abs/10.1080/00028487.2011.572009.

Converse, Y.K., Hawkins, C.P., and Valdez, R.A., 1998, Habitat relationships of subadult humpback chub in the Colorado River through Grand Canyon - spatial variability and implications of flow regulation: Regulated Rivers-Research and Management, v. 14, no. 3, p. 267-284.

Douglas, M.E., and Marsh, P.C., 1996, Population estimates/population movements of Gila cypha, an endangered cyprinid fish in the Grand Canyon region of Arizona: Copeia, v. 1996, no. 1, p. 15-28.

Gloss, S.P., and Coggins, L.C., Jr., 2005, Fishes of Grand Canyon, in Gloss, S.P., Lovich, J.E., and Melis, T.S., eds., The state of the Colorado River ecosystem in Grand Canyon: U.S. Geological Survey Circular 1282, 33-56 p., accessed on May 10, 2010, at http://pubs.usgs.gov/circ/1282/.

Grams, P.E., Schmidt, J.C., and Andersen, M.E., 2010, 2008 High-flow experiment at Glen Canyon Dam - morphologic response of eddy-deposited sandbars and associated aquatic backwater habitats along the Colorado River in Grand Canyon National Park: U.S. Geological Survey Open-File Report 2010-1032, 73 p. 
Johnstone, H.C., and Lauretta, M.V., 2004, Native fish monitoring activities in the Colorado River within Grand Canyon during 2003 - annual report: Flagstaff, Ariz., SWCA, Inc. Environmental Consultants, submitted to Grand Canyon Monitoring and Research Center, cooperative agreement no. 01WRAG0046, 80 p. [Available upon request by contacting the Center Director, U.S. Geological Survey, Southwest Biological Science Center, 2255 N. Gemini Drive, Flagstaff, Ariz. 86001.]

Korman, J., 2009, Early life history dynamics of rainbow trout in a large regulated river: Vancouver, University of British Columbia, Ph.D. dissertation, 233 p.

Korman, J., and Campana, S.E., 2009, Effects of hydropeaking on nearshore habitat use and growth of age- 0 rainbow trout in a large regulated river: Transactions of the American Fisheries Society, v. 138, no. 1, accessed on June 1, 2011, at http://www.tandfonline.com/doi/abs/10.1577/T08-026.1.

Korman, J., Kaplinski, M., and Melis, T.S., 2011, Effects of fluctuating flows and a controlled flood on incubation success and early survival rates and growth of age- 0 rainbow trout in a large regulated river: Transactions of the American Fisheries Society, v. 140, no. 2, p. 487505, accessed on April 19, 2011, at http://www.tandfonline.com/doi/abs/10.1080/00028487.2011.572015.

Korman, J., Wiele, S.M., and Torizzo, M., 2004, Modelling effects of discharge on habitat quality and dispersal of juvenile humpback chub (Gila cypha) in the Colorado River, Grand Canyon: River Research and Applications, v. 20, no. 4, p. 379-400, accessed on February 22, 2010, at http://www3.interscience.wiley.com/cgi-bin/fulltext/107614374/PDFSTART.

Korman, J., Yard, M., Walters, C.J., and Coggins, L.G., 2009, Effects of fish size, habitat, flow, and density on capture probabilities of age- 0 rainbow trout estimated from electrofishing at discrete sites in a large river: Transactions of the American Fisheries Society, v. 138, no. 1, p. 58-75, accessed on June 1, 2011, at http://www.tandfonline.com/doi/abs/10.1577/T08-025.1.

Makinster, A.S., Persons, W.R., Avery, L.A., and Bunch, A.J., 2010, Colorado River fish monitoring in Grand Canyon, Arizona-2000 to 2009 summary: U.S. Geological Survey Open-File Report 2010-1246, 26 p., accessed on November 5, 2010, at http://pubs.usgs.gov/of/2010/1246/.

McKinney, T., Speas, D.W., Rogers, R.S., and Persons, W.R., 2001, Rainbow trout in a regulated river below Glen Canyon Dam, Arizona, following increased minimum flows and reduced discharge variability: North American Journal of Fisheries Management, v. 21, no. 1, p. 216-222, accessed on August 23, 2011, at http://www.tandfonline.com/doi/abs/10.1577/15488675(2001)021\%3C0216:RTIARR\%3E2.0.CO;2.

Minckley, W.L., 1991, Native fish of the Grand Canyon region - an obituary?, in Marzolf, G.R., ed., Colorado River ecology and dam management: Washington, D.C., National Academy Press, p. 124-177.

Minckley, W.L. and Meffe, G.K., 1987, Differential selection by flooding in stream fish communities of the arid American Southwest, in Matthews, W.J., Heins, D.C., eds., Community and evolutionary ecology of North American stream fishes, University of Oklahoma Press, Norman, Okla., p. 93-104.

Protiva, F.R., Ralston, B.E., Stone, D.M., Kohl, K.A., Yard, M.D., and Haden, G.A., 2010, Effects of Glen Canyon Dam discharges on water velocity and temperatures at the confluence of the Colorado and Little Colorado Rivers and implications for habitat for young-of-year 
humpback chub (Gila cypha): U.S. Geological Survey Open-File Report 2010-1137, 24 p., accessed on July 27, 2010, at http://pubs.usgs.gov/of/2010/1137/.

Robinson, A.T., Clarkson, R.W., and Forrest, R.E., 1998, Dispersal of larval fishes in a regulated river tributary: Transactions of the American Fisheries Society, v. 127, no. 5, p. 772-786, accessed on Jun 1, 2011, at http://www.tandfonline.com/doi/abs/10.1577/15488659\%281998\%29127\%3C0772\%3ADOLFIA\%3E2.0.CO\%3B2.

Schmidt, J.C., Topping, D.J., Rubin, D.M., Hazel, J.E., Jr., Kaplinski, M., Wiele, S.M., and Goeking, S.A., 2007, Streamflow and sediment data collected to determine the effects of low summer steady flows and habitual maintenance flows in 2000 on the Colorado River between Lees Ferry and Bright Angel Creek, Arizona: U.S. Geological Survey Open-File Report 20071268, 79 p., accessed on March 17, 2010, at http://pubs.usgs.gov/of/2007/1268/.

Speas, D.W., Persons, W.R., Rogers, R.S., Ward, D.L., Makinster, A.S., and Slaughter, J.E., IV, 2004, Effects of low steady summer flows on rainbow trout in the Lee's Ferry tailwater, 2000: Phoenix, Arizona Game and Fish, submitted to U.S. Geological Survey, Grand Canyon Monitoring and Research Center, cooperative agreement no. 1425-98-FC-40-22690, 38 p., accessed on August 23, 2011, at http://www.gcmrc.gov/library/reports/biological/Fish_studies/ AZGame\&Fish/2004/Speas2004.pdf.

Stone, D.M., and Gorman, O.T., 2006, Ontogenesis of endangered humpback chub (Gila cypha) in the Little Colorado River, Arizona: American Midland Naturalist, v. 155, no. 1, p. 123-135, accessed on August 23, 2011, at http://dx.doi.org/10.1674/00030031(2006)155[0123:OOEHCG]2.0.CO;2.

Trammell, M., Valdez, R.A., Carothers, S.W., and Ryel, R., 2002, Effects of a low steady summer flow experiment on native fishes of the Colorado River in Grand Canyon-final report: Flagstaff, Ariz., SWCA, Inc. Environmental Consultants, submitted to U.S. Geological Survey, Grand Canyon Monitoring and Research Center, cooperative agreement no. 99-FC40-2260, 77 p. [Available upon request by contacting the Center Director, U.S. Geological Survey, Southwest Biological Science Center, 2255 N. Gemini Drive, Flagstaff, Ariz. 86001.]

U.S. Department of the Interior, 1995, Operation of Glen Canyon Dam Final Environmental Impact Statement: Salt Lake City, Utah, Bureau of Reclamation, Upper Colorado Region, 337 p.

Valdez, R.A., Carothers, S.W., House, D.A., Douglas, M.E., Ryel, R.J., Bestgen, K.R., and Wegner, D.L., 2000, A program of experimental flows for endangered and native fishes of the Colorado River in Grand Canyon-final report: Flagstaff, Ariz., SWCA, Inc. Environmental Consultants, submitted to U.S. Geological Survey, Grand Canyon Monitoring and Research Center, 68 p. [Available upon request by contacting the Center Director, U.S. Geological Survey, Southwest Biological Science Center, 2255 N. Gemini Drive, Flagstaff, Ariz. 86001.] Valdez, R.A., and Ryel, R.J., 1995, Life history and ecology of the humpback chub (Gila cypha) in the Colorado River, Grand Canyon, Arizona - final report: Logan, Utah, BIO/WEST, Inc., submitted to Bureau of Reclamation, contract no. 0-CS-40-09110, technical report no. TR$250-08,329$ p. [Available upon request by contacting the Center Director, U.S. Geological Survey, Southwest Biological Science Center, 2255 N. Gemini Drive, Flagstaff, Ariz. 86001.] Voichick, N., and Wright, S.A., 2007, Water-temperature data for the Colorado River and tributaries between Glen Canyon Dam and Spencer Canyon, Northern Arizona, 1988-2005: U.S. Geological Survey Data Survey Series 251, 24 p., accessed on January 14, 2010, at http://pubs.usgs.gov/ds/2007/251/. 
Yard, M.D., Coggins, L.G., Baxter, C.V., Bennett, G.E., and Korman, J., 2011, Trout piscivory in the Colorado River, Grand Canyon--effects of turbidity, temperature, and fish prey availability: Transactions of the American Fisheries Society, v. 140, no. 2, p. 471-486, accessed on April 19, 2011, at http://www.tandfonline.com/doi/abs/10.1080/00028487.2011.572011. 
This page intentionally left blank 


\section{Chapter 4. Vegetation Response to a Low Steady Summer Flow Experiment}

\section{Introduction}

The effect of river regulation on riparian vegetation includes the removal of the historical seasonal hydrologic disturbance patterns (Stromberg, 1997) and the reduction and coarsening of sediment inputs (Lowrance and others, 1986; Stevens, 1989a; Schmidt and others, 2004). Both of these alterations affect initial colonization dynamics that can promote exotic species introductions following disturbance (Naiman and Decamps, 1997; Stromberg, 1997; Sher and others, 2002; Cooper and others, 2003). The regulation of the Colorado River imposed by the installation of Glen Canyon Dam resulted in reduced annual release volumes, a reduced spring runoff hydrograph, and a shift in the peak discharges from spring to the summer and winter months. The shift in peak discharges coincided with power demands in the Southwestern United States (Turner and Karpiscak, 1980; Topping and others, 2003; Korman and others, 2004). The changes in the hydrograph shifted the timing of disturbance for extant riparian vegetation and seedlings from spring to early summer. The reduced annual hydrograph and reduced disturbance interval resulted in exposure of substrates and subsequent expanded plant colonization (Turner and Karpiscak, 1980; Carothers and Brown, 1991; Webb and others, 2002).

Introduction of tamarisk (Tamarix spp.), a nonnative species, into the Colorado River Basin began in the 19th century (Clover and Jotter, 1944). Although tamarisk proliferated in the early $20^{\text {th }}$ century before river regulation (Birken and Cooper, 2006), its expansion in the Western United States also benefitted from the hydrologic shifts associated with regulation in the 1050s and 1960s (Stromberg, 1997; Stevens and Waring, 1986; Turner and Karpiscak, 1980). Because tamarisk produces copious seeds continuously from late spring through the summer months (coincident with the shift in the hydrologic peak) and the seeds germinate quickly, it readily occupied the newly exposed shorelines and became a dominant species along the Colorado River (Turner and Karpiscak, 1980; Carothers and Brown, 1991; Ralston and others, 2008; fig. 4.1). Even though tamarisk provides habitat for riparian bird species (Shafroth and others, 2005), the Glen Canyon Dam Adaptive Management Program suggests promoting native species within the riparian community and notes that hydrologic experiments that promote the successful colonization of tamarisk is a concern to resource managers. 


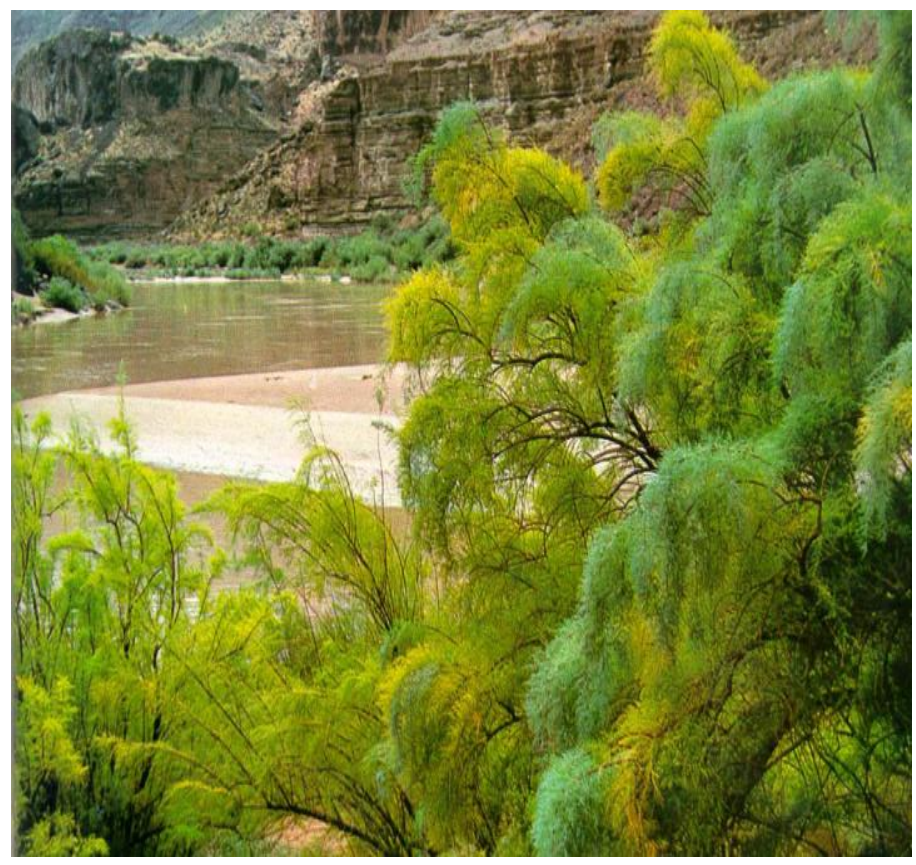

Figure 4.1. Tamarisk vegetation dominates shoreline vegetation along the Colorado River.

The expansion of tamarisk along the river corridor in Grand Canyon is associated with the initial operations of Glen Canyon Dam in 1963 (fig. 4.2; Carothers and Brown, 1991) and flood releases in 1983-84 (Stevens and Waring, 1986; Mortenson and Weisberg, 2010). In both cases, newly exposed, unvegetated substrates were available for colonization by tamarisk. Though other factors contribute to the establishment of tamarisk within the Colorado River ecosystem (CRE), a significant factor is that tamarisk can outcompete other species when substrates are bare (Sher and others, 2002). The regulation of the Colorado River by Glen Canyon Dam reduced the annual flood volume by more than 50 percent (Topping and others, 2003) and exposed shoreward substrates that previously were subject to annual scour that inhibited colonization (Clover and Jotter, 1944; Carothers and Brown, 1991). Flood releases from Glen Canyon Dam in the mid-1980s resulted in removal of 50 percent of the postdam vegetation and establishment of bare sandbars and channel margins for a secondary expansion of tamarisk with little competition (Stevens and Waring, 1986). In both instances, tamarisk dominated when bare substrates were made available. 


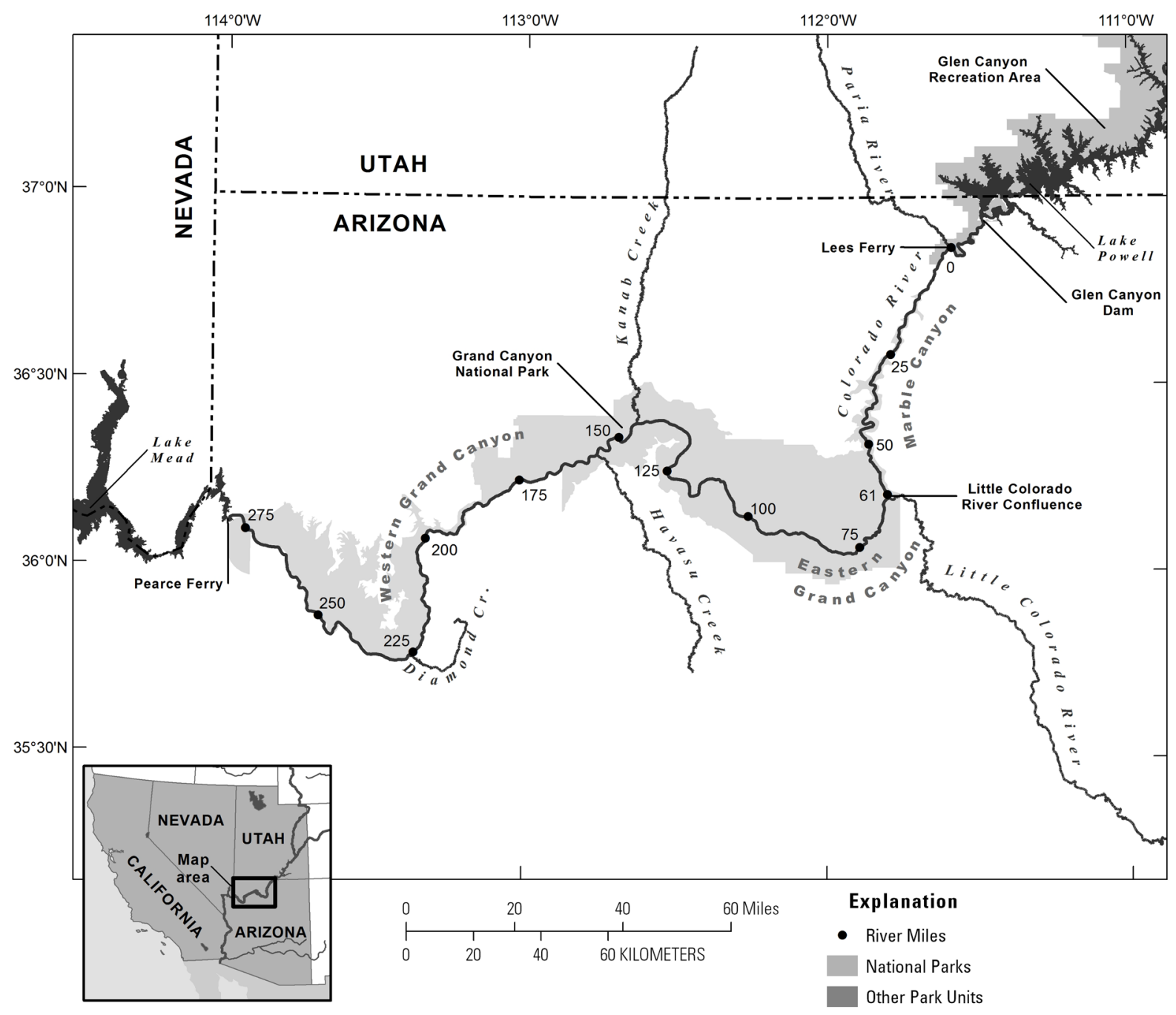

Figure 4-2. Map of the Colorado River downstream from Glen Canyon Dam. River mile (RM) designations occur at 25-mile intervals starting from Lees Ferry, designated as RM 0 . Large tributaries to the mainstem, including the Little Colorado River, are identified.

\section{Low Steady Summer Flow Hydrograph and Tamarisk Response}

The combination of sustained high releases from the dam in Period I and reduced steady discharges in Period II presented an atypical hydrograph for the Colorado River following regulation. Under annual operating plans, spring discharges (March through May) from Glen Canyon Dam averaged between 271 and $289 \mathrm{~m}^{3} / \mathrm{s}$ from 1992 to 1995 and then increased to average volumes between 403 and $640 \mathrm{~m}^{3} / \mathrm{s}$ from 1996 to 2000 (U.S. Geological Survey, 2010). Average monthly discharges in June during the 1990s were either equal to or greater than the previous months' discharges, as the dam was operated to meet increasing electrical demands associated with the summer months (Korman and others, 2004). The discharge in June 2000 differed from this pattern because the average monthly volume in June 2000 was less than the previous months' volumes. As with the tamarisk colonization events following initial dam operations in 1963 and the mid-1980s flooding (Carothers and Brown, 1991; Turner and 
Karpiscak, 1980; Stevens and Waring, 1986), the LSSF hydrograph created conditions favoring a tamarisk colonization event.

The sustained discharges in April and May and the spring habitat maintenance flows (HMF) in 2000 resulted in sediment export from eddies and deposition at mid-elevation sandbars (Hazel and others, 2006; Schmidt and others 2007). Scour of vegetation occurred below the 437 $\mathrm{m}^{3} / \mathrm{s}$ stage elevation and partial burial of vegetation occurred at the mid-elevation stages, which are equivalent to discharges between 538 and $877 \mathrm{~m}^{3} / \mathrm{s}$ (Porter, 2002; Hazel and others, 2006, Schmidt and others, 2007). The beaches below stage elevations of $437 \mathrm{~m}^{3} / \mathrm{s}$ that were exposed in June, when discharge volume was reduced to $226 \mathrm{~m}^{3} / \mathrm{s}$ stage elevations, provided largely unoccupied areas for vegetation colonization, principally by tamarisk (Porter, 2002). The buried areas associated with mid-elevation sediment deposition above the $437 \mathrm{~m}^{3} / \mathrm{s}$ stage and to as much as the $877 \mathrm{~m}^{3} / \mathrm{s}$ stage also provided a disturbance event for extant plant response.

As the summer proceeded, tamarisk seedlings reached their greatest densities in the areas closest to the shoreline, which also were the barest areas (Porter, 2002). The profuse seed production and quick germination abilities of tamarisk (Stromberg, 1997; Sher and others, 2002) were coincident with the exposure of shorelines in June. The expansive growth of tamarisk in 2000 is quantified by a mean stem density of $196 \mathrm{stems} / \mathrm{m}^{2}$ recorded in July and the 219 percent increase in stem densities (626 stems $\left./ \mathrm{m}^{2}\right) 30$ days later in August (Porter, 2002; fig. 4.3). These latter stem densities were comparable to those observed by Stevens and Waring (1986) following the mid-1980s floods and to those observed by Stromberg (1997) on the San Pedro River in southern Arizona. The availability of water relative to the location of the seeds along the bank and the absence of competition supported tamarisk's successful colonization (Stevens and Waring, 1986; Sher and others, 2002). Porter (2002) indicated that the tamarisk establishment was greatest at the mid-shore stage elevations (approximately $382 \mathrm{~m}^{3} / \mathrm{s}$ stage elevation) and below. The successful colonization by tamarisk within these stage elevations suggests an optimal soil/water relation within those stage elevations compared to higher stage elevations.

Tamarisk's successful colonization associated with the LSSF is attributable to the antecedent flows in the spring and the timing of reduced flows starting in June. The sustained higher discharges in the spring and the May HMF scoured vegetation at low stage elevations. The exposure of bare areas in June coincided with the timing of tamarisk seedling production and was approximately 1 month later than the seedling production of native riparian species such as Goodding's willow (Salix gooddingii) and Fremont cottonwood (Populus fremontii) (Stromberg, 1993). The small abundance of these native species in the CRE further limited contributing seed sources for either of these species. The newly scoured areas provided a substrate for tamarisk colonization in the absence of competition from other woody riparian species. 


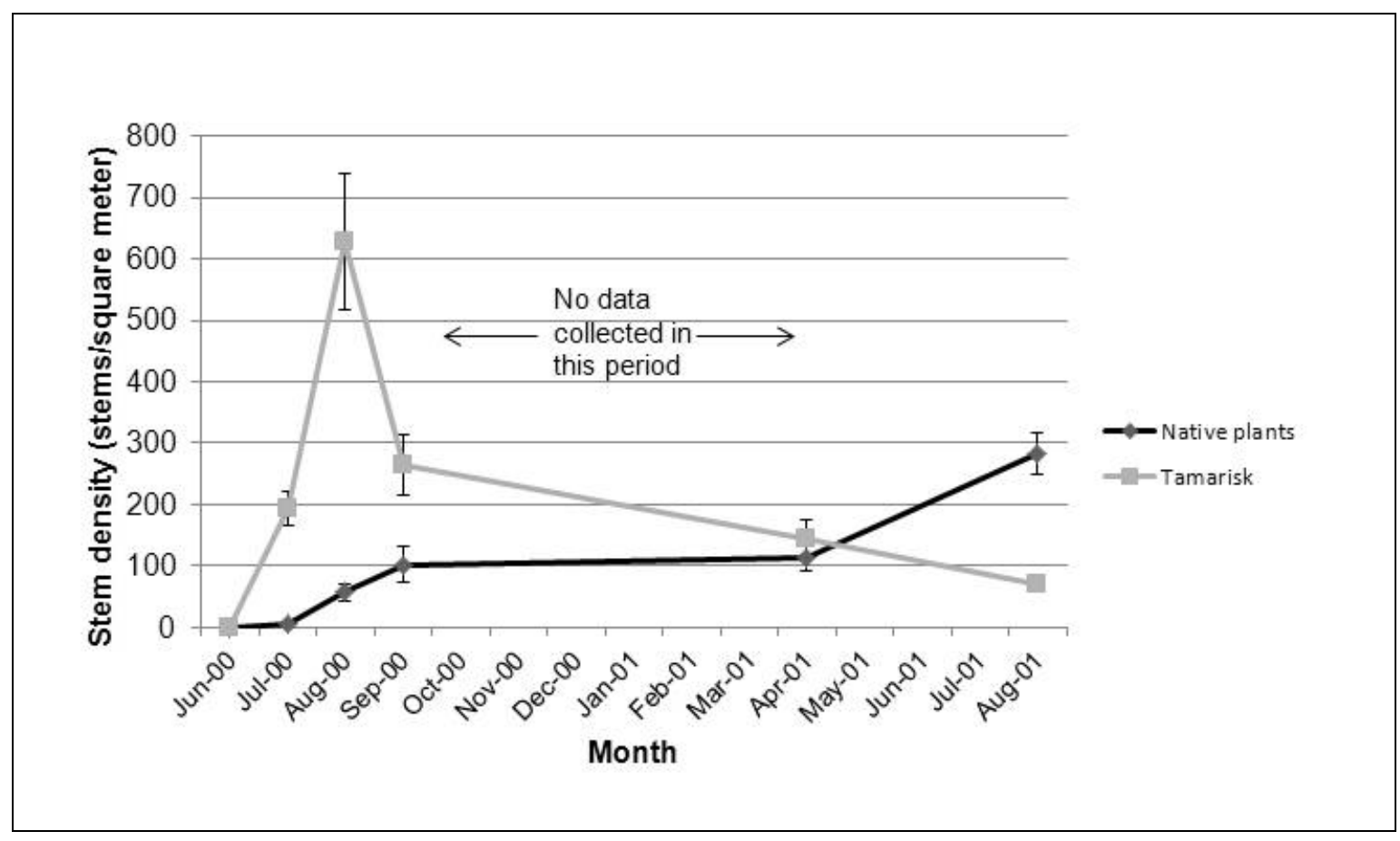

Figure 4.3. Mean stem density of tamarisk (Tamarix spp.) and native plants below $538 \mathrm{~m} / \mathrm{s}$ stage elevation in 2000 and 2001. Error bars represent one standard error (data from Porter, 2002).

\section{Low Steady Summer Flow Hydrograph and Native Species Response}

Native woody riparian plant species found along the Colorado River in Grand Canyon produce seeds in either the spring (for example, coyote willow (Salix exigua), and Goodding's willow) or late summer and fall (for example, arrowweed (Pluchea sericea), mesquite (Prosopis glandulosa), and seepwillow (Baccharis spp.)). The timing and duration of flooding affects germination success of wetland plant species and the availability of seeds for subsequent germination. Some of these species (coyote willow and arrowweed) also reproduce vegetatively. Vegetative reproduction, a form of asexual plant reproduction, also is a common form of expansion among some wetland species (for example, common reed (Phragmites australis), bulrush (Schoenoplectus sp.), and horsetail (Equisetum sp.).

Vegetative reproduction, rather than seed germination, was the dominant form of establishment by and expansion of native plants following the spring HMF (Porter, 2002). A seed bank study conducted during the 1996 high-flow experiment (HFE), or artificial flood, in Grand Canyon determined that the 7-day sustained flood flows were sufficient to remove seeds stored in shoreline sediment deposits (Kearsley and Ayers, 1999). The LSSF experiment Period I discharge and HMF that spanned a 2-month period likely removed seeds stored in seed banks. In addition, the timing of the reduced steady-flow volumes in June 2000 preceded seed production of wetland species, which occurs in late summer and early fall, and was past the viability window of most seeds produced by native woody riparian vegetation earlier in the spring (for example, seed viability is 1-5 weeks for willows) (Stromberg, 1993). The abrupt change in hydrology between May and June also reduced the water table elevation and may have compromised any dispersed seeds germinating at the $538 \mathrm{~m}^{3} / \mathrm{s}$ stage elevations (Stromberg, 1993). 
Common reed, bulrush, horsetails, and sedges became established in the low-elevation sandbar areas through the summer months of 2000, but at a slower rate than tamarisk (Porter, 2002). By August 2000, stem density of native riparian species averaged $56 \mathrm{stems} / \mathrm{m}^{2}$ compared to $626 \mathrm{stems} / \mathrm{m}^{2}$ of tamarisk (fig. 4-3). Densities of native plants followed a progression of lowest stem densities near the edge of the water and highest densities near establish plants located above the $538 \mathrm{~m}^{3} / \mathrm{s}$ stage elevation (Porter, 2002). Plants reproducing vegetatively would follow this pattern of expansion.

\section{Plant Response to September Habitat Maintenance Flow}

The September HMF that was intended to disadvantage nonnative fish (Valdez and others, unpub. report, 2000) affected other resources. This small, short-duration flood had the effect of reducing tamarisk stem densities by 57 percent (Porter, 2002). The resulting stem densities of tamarisk were approximately equal to those observed in July (fig. 4-3). Porter (2002) reported that the HMF had little effect on native stem densities (fig. 4-3). Instead, stem densities of native species continued to increase in September. The vegetative growth observed in native, flood-adapted species might have represented a late-season compensatory response to the shortterm flood disturbance (Kozlowski, 1984). Nutrients delivered to the flood-tolerant plants during the short flood pulse might have been quickly absorbed (Kozlowski, 1984) and contributed to the observed growth.

Extended inundation from flooding may have resulted in mortality among tamarisk seedlings (Koslowski, 1984; Casanova and Brock, 2000). The decline in stem densities observed for tamarisk following the HMF was likely associated with the removal of the youngest seedlings. Older tamarisk seedlings (12 weeks or older) have greater survival rates and are more resistant to uprooting by flooding than younger seedlings (Horton and others, 1960). Levine and Stromberg (2001) also identified reduced survival among tamarisk seedlings that were subject to burial. The stem densities of tamarisk observed in September 2000 were similar to those observed in July 2000 (fig. 4-3). It is likely that the older seedlings that initially established in June survived the September HMF, whereas newly established seedlings died.

\section{Vegetation Response following the Low Summer Steady Flow}

It is difficult to evaluate the effects of a single growing season's hydrology on long-lived riparian plant species within a single year. For this reason, Porter (2002) monitored the response of vegetation into the following year to evaluate the longer-term response of vegetation (Porter, 2002). Modified Low Fluctuating Flow (MLFF) operations were released from Glen Canyon Dam from October 2000 through the following year. During this time, monthly volumes increased and maximum discharges equaled stage elevations of those in April and May 2000. The higher discharges in the winter and early spring inundated the previously exposed shorelines up to the $538 \mathrm{~m}^{3} / \mathrm{s}$ stage elevation. Tamarisk stem densities declined by 45 percent in April 2001 compared with stem densities recorded in September 2000. Native vegetation stem densities were similar to those observed in September (fig. 4-3; Porter, 2002). Tamarisk densities continued to decline in subsequent months, which had higher monthly discharges than the previous summer. The expansion of species through vegetative growth increased. Stem densities of tamarisk declined to $71 \mathrm{stems} / \mathrm{m}^{2}$ and native vegetation stem densities increased to 282 stems $/ \mathrm{m}^{2}$ by August 2001 (fig. 4-3). The combination of over-wintering mortality and inundation associated with the MLFF operations contributed to the observed decline in tamarisk stem 
densities (Porter, 2002). Inundation frequency determines vegetation composition across stage elevation gradients along shorelines of the Colorado River in Grand Canyon (Stevens and others, 1995). Tamarisk and arrowweed are associated with shoreline elevations that are inundated 16 percent of days, whereas wetland marsh species are associated with inundation frequencies of greater than 50 percent of days (Stevens and others, 1995). The decline in tamarisk seedling densities as inundation frequency increased is an expected outcome on the basis of the results of Stevens and others (1995).

MLFF operations and associated inundation frequency in 2001 favored vegetative growth and expansion of wetland species instead of tamarisk. The clonal wetland species occupy shoreline areas between 300 and $700 \mathrm{~m}^{3} / \mathrm{s}$ stage elevation and especially shoreline areas below the $566 \mathrm{~m}^{3} / \mathrm{s}$ stage elevation. Shorelines below the $566 \mathrm{~m}^{3} / \mathrm{s}$ stage elevations are inundated greater than 50 percent of days (Stevens and others 1995). The inundation frequency coincides with the tolerance to inundation of marsh species. The inundation frequency of the 2001 hydrograph was similar to the 1991 hydrograph, when Stevens and others (1995) were collecting data. The positive vegetative growth response of native wetland species that can withstand a greater inundation frequency than tamarisk observed by Porter (2002) was consistent with observations by Stevens and others (1995).

\section{Conclusions}

The LSSF experimental hydrograph, which included sustained high discharges in the spring, temporarily benefitted tamarisk rather than other woody riparian and wetland species in Grand Canyon. Porter (2002) suggests that the steady discharges favor tamarisk establishment, whereas fluctuating discharges favor increased densities of native plants. Steady discharges alone cannot account for the success of nonnative rather than native riparian species. In the unregulated San Pedro River (not shown), Stromberg (1998) indicated that winter flow peaks and high spring flows were associated with tamarisk establishment, whereas Fremont cottonwoods commonly were associated with large winter floods and high spring and early summer flows along the same stretch of river. Along the Colorado River in 2000, shorelines became bare because of the high, sustained discharges in Period I. The LSSF hydrograph supported the germination of tamarisk seedlings below the $538 \mathrm{~m}^{3} / \mathrm{s}$ stage elevation because the sustained high discharges in the spring scoured vegetation below the $538 \mathrm{~m}^{3} / \mathrm{s}$ stage elevation and created bare shorelines when discharges reached $226 \mathrm{~m}^{3} / \mathrm{s}$ in June 2000. The timing of the reduced discharges in June that coincided with seed production of tamarisk and the open areas for seedling germination created a colonization opportunity for tamarisk: the species is successful under high light conditions and in the absence of competition from other plants (Sher and others, 2002; Sher and Marshall, 2003). The tamarisk seedling success is not solely attributable to the low steady discharge.

In contrast to the uncertainty associated with steady flows and exotic species expansion, the decline in tamarisk seedlings in the fall of 2000 is attributable to the September HMF and the return to MLFF operations in October. The HMF buried and removed some of the seedlings that germinated later in the summer. Mortality of tamarisk seedlings and seedlings of other woody vegetation associated with late summer flooding occurs in other Southwestern river systems (Stromberg, 1997). If other woody riparian species seedlings had been present in the plots established in 2000, then there would have been mortality among these species also. The higher volume MLFF in the winter and summer of 2001 drowned 50 percent of the remaining tamarisk seedlings through continuous or partial inundation. The tamarisk seedlings from 2000 associated 
with the lower half of the exposed shorelines died because of extended inundation under the MLFF operations.

In the absence of the spring scouring flows, the persistent clonal wetland species likely would have expanded into the open areas in June. Vegetation composition along shorelines might have been more homogeneous in association with the steady flows, but the stem densities associated with the clonal vegetation might have been a deterrent to extensive tamarisk seedling germination. The presence of vegetation along a shoreline under steady operations also may have benefitted young fish through increased shoreline warming resulting from decreasing velocities and by providing cover for young fish. In the face of tamarisk seedling colonization, high discharges that result in extended periods of inundation increase tamarisk seedling mortality.

\section{References}

Birkin, A.S., and Cooper, D.J., 2006, Processes of Tamarix invasion and floodplain development along the Lower Green River, Utah: Ecological Applications, v. 16, no. 3, p. 1103-1120, accessed on March 8, 2011, at http://dx.doi.org/10.1890/10510761(2006)016[1103:POTIAF]2.0.CO;2.

Carothers, S.W., and Brown, B.T., 1991, The Colorado River through Grand Canyon-natural history and human change: Tucson, University of Arizona Press, 235 p.

Casanova, M.T. and Brock, M.A., 2000, How do depth, duration and frequency of flooding influence the establishment of wetland plant communities?: Plant Ecology, v. 147, no. 2, p. 237-250, accessed on August 23, 2011 at http://www.springerlink.com/content/h847526076116510/.

Clover, E.U., and Jotter, L., 1944, Floristic studies in the canyon of the Colorado and tributaries: American Midland Naturalist, v. 32, no. 3, p. 591-642, accessed on December 7, 2009, at http://www.jstor.org/stable/pdfplus/2421241.pdf.

Cooper, D.J., Andersen, D.C., and Chimner, R.A., 2003, Multiple pathways for woody plant establishment on floodplains at local to regional scales: Journal of Ecology, v. 91, no. 2, p. 182-196, accessed on January 11, 2010, at http://www.jstor.org/stable/pdfplus/3599754.pdf.

Hazel, J.E., Jr., Topping, D.J., Schmidt, J.C., and Kaplinski, M., 2006, Influence of a dam on fine-sediment storage in a canyon river: Journal of Geophysical Research, v. 111, no. F01025, p. 1-16, accessed on December 28, 2009, at http://www.agu.org/journals/jf/jf0601/2004JF000193/2004JF000193.pdf.

Horton, J.J., Mounts, F.C. and Kraft, J.M., 1960, Seed germination and seedling establishment of phreatophyte species, Rocky Mountain Forest and Range Experiment Station Paper No. 48: Fort Collins, U.S. Department of Agriculture, Forest Service Station, 16 p.

Kearsley, M.J.C., and Ayers, T.J., 1999, Riparian vegetation responses - snatching defeat from the jaws of victory and vice versa, in Webb, R.H., Schmidt, J.C., Marzolf, G.R., and Valdez, R.A., eds., The controlled flood in Grand Canyon, v. 110: Washington, D.C., American Geophysical Union, Geophysical Monograph Series, p. 309-327.

Korman, J., Wiele, S.M., and Torizzo, M., 2004, Modelling effects of discharge on habitat quality and dispersal of juvenile humpback chub (Gila cypha) in the Colorado River, Grand Canyon: River Research and Applications, v. 20, no. 4, p. 379-400, accessed on February 22, 2010, at http://www3.interscience.wiley.com/cgi-bin/fulltext/107614374/PDFSTART.

Kozlowski, T.T., 1984, Plant responses to flooding of soil: Bioscience, v. 34, no. 3, p. 162-167, accessed on August 19, 2011, at http://www.jstor.org/stable/1309751. 
Levine, C.M. and Stromberg, J.C., 2001, Effects of flooding on native and exotic plant seedlings - implications for restoring south-western riparian forests by manipulating water and sediment flows: Journal of Arid Environments, v. 49, no. 1, p. 111-131, accessed on August 19, 2011, at http://www.sciencedirect.com/science/article/pii/S0140196301908377.

Lowrance, R., Sharpe, J.K. and Sheridan, J.M., 1986, Long-term sediment deposition in the riparian zone of a coastal plain watershed: Journal of Soil Water Conservation, v. 41, no. 4, p. 266-271, accessed on August 19, 2011, at http://www.jswconline.org/content/41/4/266. short.

Mortenson, S.G., and Weisberg, P.J., 2010, Does river regulation increase the dominance of invasive woody species in riparian landscapes?; Global Ecology and Biogeography, v. 19, no. 4, p. 562-574, accessed on August 19, 2011, at http://onlinelibrary.wiley.com/doi/10.1111/j.1466-8238.2010.00533.x/full.

Naiman, R.J., and Decamps, H., 1997, The ecology of interfaces-riparian zones: Annual Review of Ecology and Systematics v. 28, p. 621-658, accessed on August 19, 2011, at http://www.jstor.org/stable/2952507.

Porter, M.E., 2002, Riparian vegetation responses to contrasting managed flows of the Colorado River in Grand Canyon, Arizona: Flagstaff, Northern Arizona University, M.S. thesis, 33 p.

Ralston, B.E., Davis, P.A., Weber, R.M., and Rundall, J.M., 2008, A vegetation database for the Colorado River ecosystem from Glen Canyon Dam to the western boundary of Grand Canyon National Park, Arizona: U.S. Geological Survey Open-File Report 2008-1216, 37 p.

Schmidt, J.C., Topping, D.J., Grams, P.E., and Hazel, J.E., Jr., 2004, System-wide changes in the distribution of fine sediment in the Colorado River corridor between Glen Canyon Dam and Bright Angel Creek, Arizona-final report: Logan, Utah, submitted to U.S. Geological Survey, Grand Canyon Monitoring and Research Center, cooperative agreement no. 1425-98-FC-4022640, $107 \mathrm{p}$.

Schmidt, J.C., Topping, D.J., Rubin, D.M., Hazel, J.E., Jr., Kaplinski, M., Wiele, S.M., and Goeking, S.A., 2007, Streamflow and sediment data collected to determine the effects of low summer steady flows and habitual maintenance flows in 2000 on the Colorado River between Lees Ferry and Bright Angel Creek, Arizona: U.S. Geological Survey Open-File Report 20071268, 79 p., accessed on March 17, 2010, at http://pubs.usgs.gov/of/2007/1268/.

Shafroth, P.B., Cleverly, J.R., Dudley, T.L., Taylor, J.P., Van Riper, C., Weeks, E.P., and Stuart, J.N., 2005, Control of Tamarix in the Western United States - implications for water salvage, wildlife use, and riparian restoration: Environmental Management, v. 35, no. 3, p. 231-246, accessed on August 23, 2011, at http://www.springerlink.com/content/u8577m500748w371/.

Sher, A.A., Marshall, D.L., and Gilbert, S.A., 2000, Competition between native Populus deltoides and invasive Tamarix ramosissima and the implications for reestablishing flooding disturbance: Society of Conservation Biology, v. 14, no. 6, p. 1744-1754, accessed on January 12, 2010, at http://www.jstor.org/stable/2641526.

Sher, A.A., Marshall, D.L., and Taylor, J.P., 2002, Establishment patterns of native Populus and Salix in the presence of invasive, nonnative Tamarix: Ecological Applications, v. 12, no. 3, p. 760-772, accessed on August 23, 2011, at http://www.jstor.org/stable/3060987.

Stevens, L.E., 1989a, Mechanisms of riparian plant community organization and succession in the Grand Canyon, Arizona: Flagstaff, Northern Arizona University, Ph.D. dissertation, 124 p. Stevens, L.E., 1989, The status of ecological research on tamarisk (Tamaricaceae: Tamarix ramosissima) in Arizona, in Kunzman, M.R., Johnson, R.R., and Bennett, P.S., eds., Tamarisk control in southwestern United States--special report no. 9, Tucson, Proceedings: National 
Park Service, Cooperative National Park Resources Studies Unit, University of Arizona, p. 99105.

Stevens, L.E., Schmidt, J.C., Ayers, T.J., and Brown, B.T., 1995, Flow regulation, geomorphology, and Colorado River marsh development in the Grand Canyon, Arizona: Ecological Applications, v. 5, no. 4, p. 1025-1039, accessed on December 10, 2009, at http://www.jstor.org/stable/pdfplus/2269352.pdf.

Stevens, L.E., and Waring, G.L., 1986, Effects of post-dam flooding on riparian substrates, vegetation, and invertebrate populations in the Colorado River corridor in Grand Canyon, Arizona: Flagstaff, Ariz., Bureau of Reclamation, Glen Canyon Environmental Studies, contract no. IA4-AA-40-01930, GCES 19/87, 175 p. [Available from National Technical Information Service, Springfield, Va. as NTIS Report PB88-183488.]

Stromberg, J.C., 1993, Frémont cottonwood-Gooding willow riparian forests - a review of their ecology, threats and recovery potential: Journal of the Arizona-Nevada Academy of Science, v. 27, no. 1, p. 97-110, accessed on August 19, 2011, at http://www.jstor.org/stable/40023710.

Stromberg, J.C., 1997, Growth and survivorship of Fremont cottonwood, Gooding willow, and salt cedar seedlings after large floods in central Arizona: Great Basin Naturalist, v. 57, no. 3, p. 198-208.

Stromberg, J., 1998, Dynamics of Fremont cottonwood (Populus fremontii) and salt cedar (Tamarix chinensis) populations along the San Pedro River, Arizona: Journal of Arid Environments, v. 40, no. 2, p. 133-155, accessed on August 23, 2011, at http://dx.doi.org/10.1006/jare.1998.0438.

Topping, D.J., Schmidt, J.C., Vierra, L.E. Jr., 2003, Computation and analysis of the instantaneous-discharge for the Colorado River at Lees Ferry, Arizona-May 8, 1921, through September 30, 2000: U.S. Geological Survey Professional Paper 1677, 118 p., accessed on January 28, 2010, at http://pubs.usgs.gov/pp/pp1677/pdf/pp1677.pdf.

Turner, R.M., and Karpiscak, M.M., 1980, Recent vegetation changes along the Colorado River between Glen Canyon Dam and Lake Mead, Arizona: U.S. Geological Survey Professional Paper 1132, $125 \mathrm{p}$.

U.S. Geological Survey, 2010, National Water Information System (NWISWeb): U.S. Geological Survey database, accessed April 27, 2010, at http://waterdata.usgs.gov/nwis.

Valdez, R.A., Carothers, S.W., House, D.A., Douglas, M.E., Ryel, R.J., Bestgen, K.R., and Wegner, D.L., 2000, A program of experimental flows for endangered and native fishes of the Colorado River in Grand Canyon-final report: Flagstaff, Ariz., SWCA, Inc. Environmental Consultants, submitted to U.S. Geological Survey, Grand Canyon Monitoring and Research Center, 68 p. [Available upon request by contacting the Center Director, U.S. Geological Survey, Southwest Biological Science Center, 2255 N. Gemini Drive, Flagstaff, Ariz. 86001.] Webb, R.H., Melis, T.S., and Valdez, R.A., 2002, Observations of environmental change in Grand Canyon, Arizona: U.S. Geological Survey Water-Resources Investigation Report 024080, 33 p., accessed on September 7, 2010, at http://pubs.usgs.gov/wri/wri024080/pdf/WRIR4080.pdf. 


\section{Chapter 5. Effects of the Low Steady Summer Flow Experiment on Campsite Area, Rafting Safety and Travel Time, and Overall Recreational Experience}

\section{Introduction}

Discharge rates, patterns of water release, and available campsite area affect the quality of whitewater rafting in Grand Canyon, a high-profile recreational activity (fig. 5.1; Shelby and others, 1983; Bishop and others, 1987; Shelby and others, 1992; Stewart and others, unpub. report, 2000). Social factors also contribute to the recreational experience, including the number of encounters with other groups, the experience of the encounters (Stewart and others, unpub. report, 2000; Jonas and others, 2000), and how time is spent while on the river (for example, travel time versus off-river experiences (Bishop and others, 1987; Roberts and Bieri, unpub. report, 2001). Other factors affecting the rafting experience include perceptions of safety and the occurrence and types of accidents (Jalbert, unpub. report, 1992, 2009). Several scientists evaluated Period II of the Low Summer Stead Flow (LSSF) experiment to determine how the steady flow volume of $226 \mathrm{~m}^{3} / \mathrm{s}$ affected rafting travel time, time spent at attractions, incidence rate and types of accidents, and camping experiences (fig. 5.1).

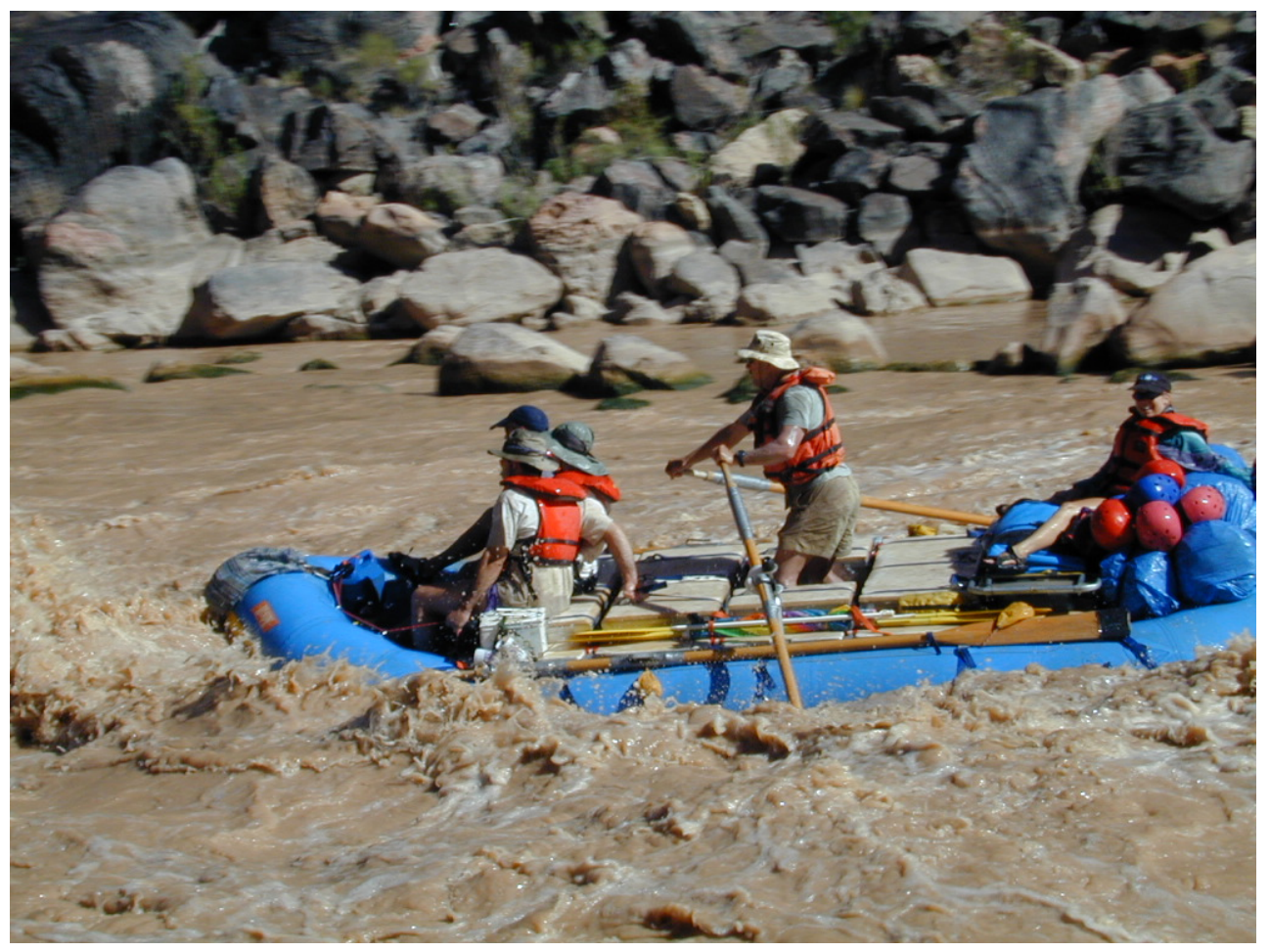

Figure 5.1. Passengers and river guide in a raft going through 205-mile rapid, Colorado River in Grand Canyon, Arizona. Photograph courtesy of the National Park Service. 


\section{Effects of Steady Discharges on Rafting Travel Time and Available Campsite Area}

Discharge rates affect the residence time of water within the Colorado River corridor in Grand Canyon (Wright and others, 2008). Besides affecting warming of the water, residence time also affects how quickly objects on the water move downstream. For whitewater rafting, discharge rates and patterns affect the amount of time rafting-trip participants spend on the water, at attraction sites, and in camp. These variables also affect the excitement level and safety of rapids (Bishop and others, 1987; Shelby and others, 1992; Behan, unpub. report, 2000; Roberts and Bieri, unpub. report, 2001). The LSSF experimental plan (Valdez and others, unpub report, 2000) did not identify negative or positive effects of the experimental hydrograph on recreational boating, but previous authors associated with the Operation of Glen Canyon Dam Final Environmental Impact Statement (GCDEIS) determined that the $226-\mathrm{m}^{3} / \mathrm{s}$ discharge represented a minimum discharge for a quality rafting experience (Bishop and others, 1987). Steady discharges were a positive variable in these studies because steady discharges made management of moored boats easier because river guides did not have to get up in the night to move boats (Bishop and others, 1987). Steady discharges made travel times more predictable. The studies completed for the GCDEIS associated with recreation (Bishop and others, 1987; Shelby and others, 1992) provide baseline information of perceptions about rafting at $226-\mathrm{m}^{3} / \mathrm{s}$ discharges, and the Period II hydrograph provided an opportunity to verify those perceptions.

Surveys of river guides from the 1980s about discharges indicated that at flows less than $283 \mathrm{~m}^{3} / \mathrm{s}$ oar boats and motorboats operators were more likely to row more frequently or run their motors more often to reach destinations than at higher discharges (Bishop and others, 1987). The guides also indicated they would spend less time at attraction sites and do not visit all sites they might with higher discharges. Guides might leave camps earlier in the day in order to reach downstream destinations. Surveys completed during the 2000 LSSF experiment by Roberts and Bieri (unpub. report, 2001) support the findings of Bishop and others (1987). Roberts and Bieri (unpub. report, 2001) surveyed oar boat and motorboat guides to determine how much time they spent at attraction sites versus time spent on the water. The researchers also asked if the 226 $\mathrm{m}^{3} / \mathrm{s}$ discharges affected campsite selection. Their report indicated that during Period II of the LSSF experiment, trips spent approximately 50 percent less time (for example, 3.5 hours versus 7 hours) at attraction sites or on off-river activities (for example, hiking, swimming, and visiting archaeological sites). The slower speed of the water required spending more time on the water (Roberts and Bieri, unpub. report, 2001). The shortened period for off-river activities occurred with either motor- or oar-powered trips. Trips in which time spent off the river deviated only slightly from that of regular summer flows were short oar trips and short motor trips. These shorter trips already maximize time on the river and cannot shorten attraction-site stops below a certain threshold; there is a point at which a stop is not logistically feasible. These trips may have forgone some attraction sites instead of shortening the time spent at them (Roberts and Bieri, unpub. report, 2001).

Roberts and Bieri (unpub. report, 2001) compared choice of attraction sites under Modified Low Fluctuating Flow (MLFF) operations (before 2000) and the LSSF experiment in 2000. There were some shifts in the rankings of attraction sites other than the top three sites that most river-trip participants visit. In 2000, stops that were ranked higher compared to previous years were sites associated with shorter hikes and easier access (table 2-1) (for example, the Little Colorado River is a site where hikes are shorter and more manageable compared to Elves 
Chasm (not shown)). The most frequently visited sites also were sites that are anticipated by most passengers on trips. Stopping at these sites, regardless of time spent at them, may be considered an essential component of the recreational experience for the participants (Roberts and Bieri, unpub. report, 2001; Jonas and Stewart, unpub. report, 2002).

Table 5.1. Comparison of the rank and frequency of visits of selected attraction sites in Grand Canyon, Ariz., visited by river-trip participants during the Low Steady Summer Flow (LSSF) experiment in 2000 and Modified Low Fluctuating Flow (MLFF) operations in previous years (adapted from Roberts and Bieri, unpub. report, 2001).

\begin{tabular}{llcc}
\hline $\begin{array}{l}\text { River mile and side of the } \\
\text { river (left (L) or right (R)) }\end{array}$ & \multicolumn{1}{c}{ Site Name } & $\begin{array}{c}\text { Rank } \\
\text { (most visited to least visited) } \\
\text { (MLFF) }\end{array}$ & $\begin{array}{c}\text { Rank } \\
\text { (most visited to least } \\
\text { visited) } \\
\text { (LSSF) }\end{array}$ \\
\hline $136.2 \mathrm{R}$ & Deer Creek & 1 & 1 \\
$156.9 \mathrm{~L}$ & Havasu & 2 & 2 \\
$32.8 \mathrm{~L}$ & Redwall Cavern & 3 & 3 \\
116.5 & Elves Chasm & 4 & 5 \\
$61.4 \mathrm{~L}$ & Little Colorado River & 5 & 4 \\
$47.2 \mathrm{R}$ & Upper Saddle & 10 & 12 \\
$31.6 \mathrm{R}$ & South Canyon & 11 & 19 \\
$53.0 \mathrm{R}$ & Nankoweap Arch site & 12 & 22 \\
$212.9 \mathrm{~L}$ & Pumpkin Springs & 16 & 11 \\
\hline
\end{tabular}

Campsite selection was the other variable evaluated by Roberts and Bieri (unpub. report, 2001). The purpose of the May habitat maintenance flow (HMF) was to rebuild backwaters and possibly low-elevation sandbars used for camping (Valdez and others, unpub report, 2000). Surveys of campsite area following the May HMF indicated that campsite area below the 708 $\mathrm{m}^{3} / \mathrm{s}$ stage elevation increased because of sediment deposition in mid-elevation sandbars (Kaplinski and others, 2005; Hazel and others, 2006; Schmidt and others, 2007). The May HMF differentially affected sandbar areas at camping sites with some sites in critical reaches (for example, Marble Canyon) increasing in area and volume, although some sites in noncritical reaches decreased in area and volume (Kaplinski and others, 2005). These changes in sandbar area may have affected campsite preferences identified by boaters during Period II. Few of the camps surveyed by Kaplinski and others (2005) coincide with those identified by Roberts and Bieri (unpub. report, 2001). Two camps that were coincident in the two studies, the Hot $\mathrm{Na} \mathrm{Na}$ Camp Site at RM 16.4L and the Football Field Camp Site at RM 137.5 (not shown), did increase in area in 2000 (Kaplinski and others, 2005).

In general, because discharge during the summer of 2000 was at a base flow of $226 \mathrm{~m}^{3} / \mathrm{s}$, greater areas of beach were exposed and available for camping, including some campsites that are only available during low water. In this case, the recreational experience might have been improved by expanded campsite availability and by being able to camp at a place that was "new" to an experienced boater. The increased availability of campsites at low water also benefitted trip schedules. A good example of this increased availability is the Hot $\mathrm{Na} \mathrm{Na}$ camp, which is a convenient distance downstream from Lees Ferry for oar boats to stop on the first night. 
Additionally, several campsites downstream from the Little Colorado River that are good lowwater camps increased campsite availability in a reach where campsites are sparse during higher discharges (Roberts and Bieri, unpub. report, 2001). The steady discharge pattern also enhanced the boating and camping experience. During fluctuating flows, shorelines become inundated or dewatered over a matter of hours, which can result in stranding of moored boats. Large motor rafts are heavy and difficult to move once stranded and, to prevent the problem, river guides have to move their boats through the night. The steady flows meant guides did not have to get up in the night to move their boats and people sleeping on shore could sleep close to the edge of the water, which is cooler in the summer (Roberts and Bieri, unpub. report, 2001).

\section{Rafting Safety during Low Steady Flows}

Rapids are an important component of rafting trips and represent locations where rafting accidents are most likely to occur (Bishop and others, 1987; Brown and Hahn-O'Neill, 1987; Underhill and others, 1987; Jalbert, unpub. report, 2009). Factors contributing to a safe, but thrilling, ride through a large rapid include prior boating experience and river discharge. River guides and private boatmen in the 1980s found that discharges greater than $1,274 \mathrm{~m}^{3} / \mathrm{s}$ and less than $283 \mathrm{~m}^{3} / \mathrm{s}$ presented greater likelihoods of accidents compared to discharges between these extremes (Bishop and others, 1987; Brown and Hahn-O'Neill, 1987; Underhill and others, 1987). The minimum discharge that river guides felt was reasonably safe for conducting commercial river trips was slightly more than $226 \mathrm{~m}^{3} / \mathrm{s}\left(238 \mathrm{~m}^{3} / \mathrm{s}\right.$ for motorboat trips and $260 \mathrm{~m}^{3} / \mathrm{s}$ for oarboat trips (Bishop and others, 1987)). At lower discharges, 65 percent of oar-boat guides and 35 percent of motorboat guides were likely to have passengers walk around rapids. The 1980s was a period of higher discharges and the guides that were interviewed likely had limited experience with discharges lower than $283 \mathrm{~m}^{3} / \mathrm{s}$ (Bishop and others, 1987; Jalbert, unpub. report, 2009).

Boating accidents during high discharges in the 1980s and in 1996 were documented in association with the high-flow experiment (HFE; Underhill and others, 1987; Harpman and Jalbert, unpub. report, 1997). Accidents associated with lower discharges were studied in the 1980s (Brown and Hahn-O'Neill, 1987) and in 1990-91 during test flows conducted in conjunction with the preparation of the GCDEIS (Jalbert, unpub. report, 1992). Both of these evaluation periods were associated with fluctuating flows. Period II of the LSSF experiment provided an opportunity to evaluate an extended period of a steady, low discharge and its relation to boating safety. Assessments of accidents involved making observations at major rapids and reviewing National Park Service (NPS) records of boating accidents, including evacuations made by the NPS (Jalbert, unpub. report, 2009). The study conducted in 2000 was limited to rapids that were accessible to observers by hiking, or through assistance from recreational and administrative river trips (Jalbert, unpub. report, 2009). Jalbert (unpub. report, 2009) compared the results for 2000 with previous studies to determine if the $226 \mathrm{~m}^{3} / \mathrm{s}$ discharge resulted in more accidents than larger discharges.

Results from the 2000 study of boating accidents indicated that grounding of motorboats was the most common accident earlier in Period II. Injury to passengers, principally arm fractures, occurred in greater frequency in the later months of Period II (Jalbert, unpub. report, 2009). The reduction in groundings as the season progressed may be an indication that riverguide experience reduced these types of accidents. The incidents of grounding as analyzed from data collected in the 1999 period were rare during higher discharges (Jalbert, unpub. report, 2009). However, the single grounding incident in 1999 required an evacuation by the NPS, whereas only 50 percent of the groundings in 2000 required evacuation (Jalbert, unpub. report, 
2009). Groundings and subsequent evacuations may occur more frequently at higher discharges, and accidents at specific rapids may usually require evacuation (for example, Hance, Crystal, or Horn Creek Rapids; not shown). Differentiating between the inherent difficulty of the rapid and discharges that cause grounding was not possible using the available data.

During the LSSF experiment, Jalbert (unpub. report, 2009) indicated that the low steady discharges affected the entire river in Grand Canyon with respect to the incidents of accidents. Among rapids where observations occurred, all rapids were associated with accidents instead of a few rapids. The greatest number of accidents was associated with Crystal Rapid followed by Hance Rapid. These are two of the more technical rapids in Grand Canyon, requiring quick maneuvering by guides to avoid large hydraulic holes and rocks. In most cases, accidents were associated with hitting exposed rocks (Jalbert, unpub. report, 2009), which affected motorboats the most. Despite the fact that twice as many accidents occurred in 2000 compared to the previous year, Jalbert (unpub. report, 2009) concluded that there was not a significant relation between the $226 \mathrm{~m}^{3} / \mathrm{s}$ discharge and increased number of boating accidents. A higher incidence of accidents cannot exclusively be assigned to lower discharges because several other factors may contribute to boating accidents.

\section{Recreational Experience Relative to the Low Summer Flows}

The factors previously discussed, the relationships between river guides, relationships with guides and passengers, time between trips, and the participant's level of rafting experience come together to define a participant's experience as enjoyable or disappointing (Shelby and others, 1992; Jonas and Stewart, unpub. report, 2002). A Colorado River rafting trip is often the trip of a lifetime for a participant and is unlikely to be repeated (Jonas and others, 2000; Jonas and Stewart, unpub. report, 2002). In this case, the participant has preconceived notions of what to expect, but his/her experience also can be affected by attitudes of the people encountered on the trip, including those viewed in a leadership role such as a commercial guide, or more experienced participants (Shelby and others, 1992; Jonas and others, 2000; Jonas and Stewart, unpub. report, 2002). Jonas and Stewart (unpub. report, 2002) argue that a participant's recreational experience is affected by these encounters and how factors including trip type, number of participants, and physical factors of river discharge and weather are interpreted or expressed among participants. Participants on trips during the summer of 2000, in which trips were scheduled with less time at attraction sites, but participants were able to utilize camp sites that were potentially larger and closer to shore (Roberts and Bieri, unpub. report, 2001; Kaplinski and others, 2005), had a different experience than trips in other years. Because they only had their trip as a reference point, the participants' experience was not reduced (Jonas and Stewart, unpub. report, 2002).

The context of the steady discharges may have added uniqueness to the trips as they took place at different discharge patterns than previous years (Jonas and Stewart, unpub. report, 2002), and most boaters would view the experience as excellent or perfect because that trip was the only reference for a passenger's viewpoint. Crowding at attractions, which can detract from the "wilderness experience," may not have been an issue during the LSSF experiment. Shorter hikes that better fit the trip's time constraints might have been completed instead of longer hikes (Roberts and Bieri, unpub. report, 2001). The lower discharges that were initially unfamiliar to some guides possibly added to the excitement of the whitewater rafting for the participant (Jonas and Stewart, unpub. report, 2002). A guide's perception and his/her reaction to a situation convey information to the participant about danger and excitement. For example, getting through 
a rapid like Horn Creek without incident, but still experiencing a big ride in the rapid can be a relief to all and be remembered in positive terms. Because the discharges were not extremely low, less thrilling rides in rapids and safety concerns because of exposed rocks may have been detractors. The $226 \mathrm{~m}^{3} / \mathrm{s}$ discharge minimally affected the overall multidimensional recreational experience (Jonas and Stewart, unpub. report, 2002).

\section{Conclusions}

Multiple studies evaluated single factors associated with Period II of the LSSF experiment and concluded that river guides generally adapt to the changing boating conditions, so as to ensure to an "excellent" rafting experience for guests. The aspects that were measured (for example, travel time, accidents, camping choice) were easily quantified, but they did not provide a complete evaluation of the effect the LSSF hydrograph had on the rafting experience (Jonas and Stewart, unpub. report, 2002). Each individual aspect that was studied suggests that more time was spent on the water than at attraction sites located away from the river; campsite availability increased, and the steady discharges improved overnight boat mooring and sleeping conditions. Lastly, boating accidents declined with time as guides became accustomed to the reduced discharges. Because of the multidimensional aspect of the recreational experience, evaluating discharge releases and recreational use is difficult without first understanding the basic questions about linkages between experience and resource characteristics within the river corridor (Stewart and others, unpub. report, 2000). Embedding a researcher with the recreationists (see for example, Jonas and others, 2000) is an approach that can address these questions.

\section{References}

Behan, J., 2000, Recreation in the Colorado River ecosystem and the adaptive management program - final report: U. S. Geological Survey, Grand Canyon Monitoring and Research Center, Flagstaff, Arizona, 88 p. [Available upon request by contacting the Center Director, U.S. Geological Survey, Southwest Biological Science Center, 2255 N. Gemini Drive, Flagstaff, Ariz. 86001.]

Bishop, R.C., Boyle, K.J., Welsh, M.P., Baumgartner, R.M., and Rathbun, P.R., 1987, Glen Canyon Dam releases and downstream recreation - an analysis of user preferences and economic values: Washington, D.C., Huberlein-Baumgartner Research Service, submitted to Bureau of Reclamation, Upper Colorado Region, Glen Canyon Environmental Studies, contract no. 4-CS-40-01780, technical report no. GCES/27/87, 398 p.

Brown, C.R., and Hahn-O'Neill, M.G., 1987, The effects of flows in the Colorado River on reported and observed boating accidents in Grand Canyon-final report: Flagstaff, Ariz., Glen Canyon Environmental Studies Program, submitted to Bureau of Reclamation. [Available from National Technical Information Service, Springfield, Va. as NTIS Report PB88-183553/AS.]

Harpman, D.A., Jalbert, L.M., 1997, Impacts of the Glen Canyon Dam beach/habitat building flow on recreation and hydropower-draft report: Flagstaff, Ariz., U.S. Bureau of Reclamation, Glen Canyon Environmental Studies, 24 p. [Available upon request by contacting the Center Director, U.S. Geological Survey, Southwest Biological Science Center, 2255 N. Gemini Drive, Flagstaff, Ariz. 86001.]

Hazel, J.E., Jr., Topping, D.J., Schmidt, J.C., and Kaplinski, M., 2006, Influence of a dam on fine-sediment storage in a canyon river: Journal of Geophysical Research, v. 111, no. F01025, 
p. 1-16, accessed on December 28, 2009, at

http://www.agu.org/journals/jf/jf0601/2004JF000193/2004JF000193.pdf.

Jalbert, L.M., 1992, The influence of discharge on recreational values including crowding and congestion and safety in Grand Canyon National Park - draft report: Grand Canyon National Park, submitted to U.S. Bureau of Reclamation, Glen Canyon Environmental Studies, 35 p. [Available upon request by contacting the Center Director, U.S. Geological Survey, Southwest Biological Science Center, 2255 N. Gemini Drive, Flagstaff, Ariz. 86001.]

Jalbert, L.M., 2009, The effects of the 2000 low steady summer flows on observed and reported boating accidents on the Colorado River in Grand Canyon National Park-final report: Grand Canyon National Park, submitted to U.S. Geological Survey, Grand Canyon Monitoring and Research Center, 25 p. [Available upon request by contacting the Center Director, U.S. Geological Survey, Southwest Biological Science Center, 2255 N. Gemini Drive, Flagstaff, Ariz. 86001.]

Jonas, L.M., and Stewart, W.P., 2002, An overview of various impacts to Grand Canyon River experiences, with a focus on intergroup encounters, flow levels and the 2000 low summer steady flow experiment-final report: Flagstaff, Ariz., SWCA, Inc. Environmental Consultants, submitted to U.S. Geological Survey, Grand Canyon Monitoring and Research Center. [Available upon request by contacting the Center Director, U.S. Geological Survey, Southwest Biological Science Center, 2255 N. Gemini Drive, Flagstaff, Ariz. 86001.]

Jonas, L., Stewart, W., and Larkin, K., 2000, Encountering Heidi-meeting others as a central aspect of the river experience, in Cole, D., and McCool, S., eds., Wilderness Science in a Time of Change, Ogden, Utah, Proceedings, no. RMRS-P-15-VOL-3: U.S. Department of Agriculture, Forest Service, Rocky Mountain Research Station, p. 181-187, accessed on August 23, 2011, at http://www.fs.fed.us/rm/pubs/rmrs_p015_3/rmrs_p015_3_181_187.pdf.

Kaplinski, M., Hazel, J.E., and Parnell, R., 2005, Campsite area monitoring in the Colorado River ecosystem - 1998-2003 - final report: Northern Arizona University, Department of Geology, submitted to U.S. Geological Survey, Grand Canyon Monitoring and Research Center, mod. no. 5 1425-98-FC-40-22630, 39 p.

Roberts, C.A., and Bieri, J.A., 2001, Impacts of low flows on recreational rafting traffic on the Colorado River in Grand Canyon National Park - final report: Flagstaff, Ariz., submitted to Bureau of Reclamation and U.S. Geological Survey, Grand Canyon Monitoring and Research Center, cooperative agreement no. CA8210-99-002, interagency acquisition no. 00-AA-404330, 18 p., accessed on August 23, 2011, at http://www.gcmrc.gov/library/reports/cultural/Recreation/roberts2001.pdf.

Schmidt, J.C., Topping, D.J., Rubin, D.M., Hazel, J.E., Jr., Kaplinski, M., Wiele, S.M., and Goeking, S.A., 2007, Streamflow and sediment data collected to determine the effects of low summer steady flows and habitual maintenance flows in 2000 on the Colorado River between Lees Ferry and Bright Angel Creek, Arizona: U.S. Geological Survey Open-File Report 20071268, 79 p., accessed on March 17, 2010, at http://pubs.usgs.gov/of/2007/1268/.

Shelby, B., Heberlein, T.A., Vaske, J.J., and Alfano, G., 1983, Expectations, preferences and feeling crowded in recreation activities: Leisure Sciences, v. 6, no. 1, p. 1-14.

Shelby, B., Brown, T.C., and Taylor, J.G., 1992, Streamflow and recreation: Fort Collins, Colo., U.S. Department of Agriculture, Forest Service, Rocky Mountain Forest and Range Experiment Station, general technical report RM-209, 27 p., accessed on August 23, 2011, at http://www.gcmrc.gov/library/reports/other/Recreation/Shelby1992b.pdf. 
Stewart, W., Larkin, K., Orland, B., Anderson, D., Manning, R., Cole, D., Taylor, J., and Tomar, N., 2000, Preferences of recreation user groups of the Colorado River in Grand Canyon-final report: Flagstaff, Ariz., submitted to U.S. Geological Survey, Grand Canyon Monitoring and Research Center, cooperative agreement no. 98-FG-40-0190, 232 p., accessed on August 23, 2011, at http://www.gcmrc.gov/library/reports/cultural/Recreation/Stewart2000.pdf.

Underhill, A.H., Hoffman, M.H., and Borkan, R., 1987, An analysis of recorded Colorado River boating accidents in Glen Canyon for 1980, 1982, and 1984, and in Grand Canyon for 1981 through 1983: University of Arizona, Cooperative Park Studies Unit, contribution no. 053/02, submitted to U.S. Bureau of Reclamation, Glen Canyon Environmental Studies, technical report no. 18, interagency agreement no. 4-AA-40-01930, $32 \mathrm{p}$.

Valdez, R.A., Carothers, S.W., House, D.A., Douglas, M.E., Ryel, R.J., Bestgen, K.R., and Wegner, D.L., 2000, A program of experimental flows for endangered and native fishes of the Colorado River in Grand Canyon-final report: Flagstaff, Ariz., SWCA, Inc., Environmental Consultants, submitted to U.S. Geological Survey, Grand Canyon Monitoring and Research Center, 68 p. [Available upon request by contacting the Center Director, U.S. Geological Survey, Southwest Biological Science Center, 2255 N. Gemini Drive, Flagstaff, Ariz. 86001.] Wright, S.A., Anderson, C.R., and Voichick, N., 2008, A simplified water temperature model for the Colorado River below Glen Canyon Dam: River Research and Applications, v. 25, no. 6, p. 675-686. 


\section{Chapter 6. Effect of the Low Steady Summer Flow Experiment on Angling Quality in the Lees Ferry Trout Fishery}

\section{Introduction}

Accessibility to fishing locations and the quantity and size of fish available for capture affect fishing quality in trout fisheries, including in Lees Ferry, Arizona (fig. 6.1; Bishop and others, 1987; Petering and others, 1995; Fisher, 1997; Radomski and others, 2001). Minimum discharge, magnitude of fluctuations, fish density, and food availability affect the abundance and condition of rainbow trout size classes in the fishery (McKinney and others, 2001; Speas and others, unpub. report, 2004; Korman and others, 2009; Korman and Campana, 2009). Surveys in the 1980s of preferences of Lees Ferry anglers indicated a preference for discharges between 226 and $424 \mathrm{~m}^{3} / \mathrm{s}$. Anglers identified that lower discharges increased the likelihood of catching large fish and being able to fish in preferred areas (Bishop and others, 1987). When surveyed about specific discharge patterns, respondents preferred steady to fluctuating discharges, and they preferred lower to higher steady discharges (Bishop and others, 1987). Anglers reiterated their preferences for reduced fluctuations and lower discharges in a 2006 knowledge assessment conducted by the U.S. Geological Survey (Melis and others, unpub. report, 2006b).

Discharge rates and patterns of water release affect the densities, composition, and drift concentration of filamentous green algae (for example, Cladophora glomerata; hereafter Cladophora), macrophytes (emergent or submerged aquatic plants), and invertebrates (Gammarus lacustris (scuds) and chironomids (midges)), all food sources for rainbow trout (Oncorhynchus mykiss) (Stevens and others, 1997; McKinney and others, 1999; Shannon and others, 2001; Melis and others, unpub. report, 2006b). Higher discharges expand the permanently wetted area along shorelines that host algae, macrophytes, and associated invertebrates. An abrupt decrease in discharge, like that between May and June 2000, can strand previously submerged periphyton (a collection of algae and microbes), macrophyte beds, associated invertebrates, and young fish (Hardwick and others, 1992; Blinn and others, 1995; McKinney and others, 1999; Korman and others, 2010). The Low Steady Summer Flow (LSSF) experiment in 2000 represented the first time since the Record of Decision (U.S. Department of the Interior, 1996) that the Lees Ferry fishery was subject to an extended period of lower discharges. An unanticipated effect of the LSSF experiment was enhanced survival of young-of-year (YOY) rainbow trout (Speas and others, unpub. report, 2004). The stabilized habitat in the summer months may have offset negative effects of the abrupt change in discharge between Periods I and II of the LSSF experiment on the aquatic food base, YOY rainbow trout, and angling satisfaction. 


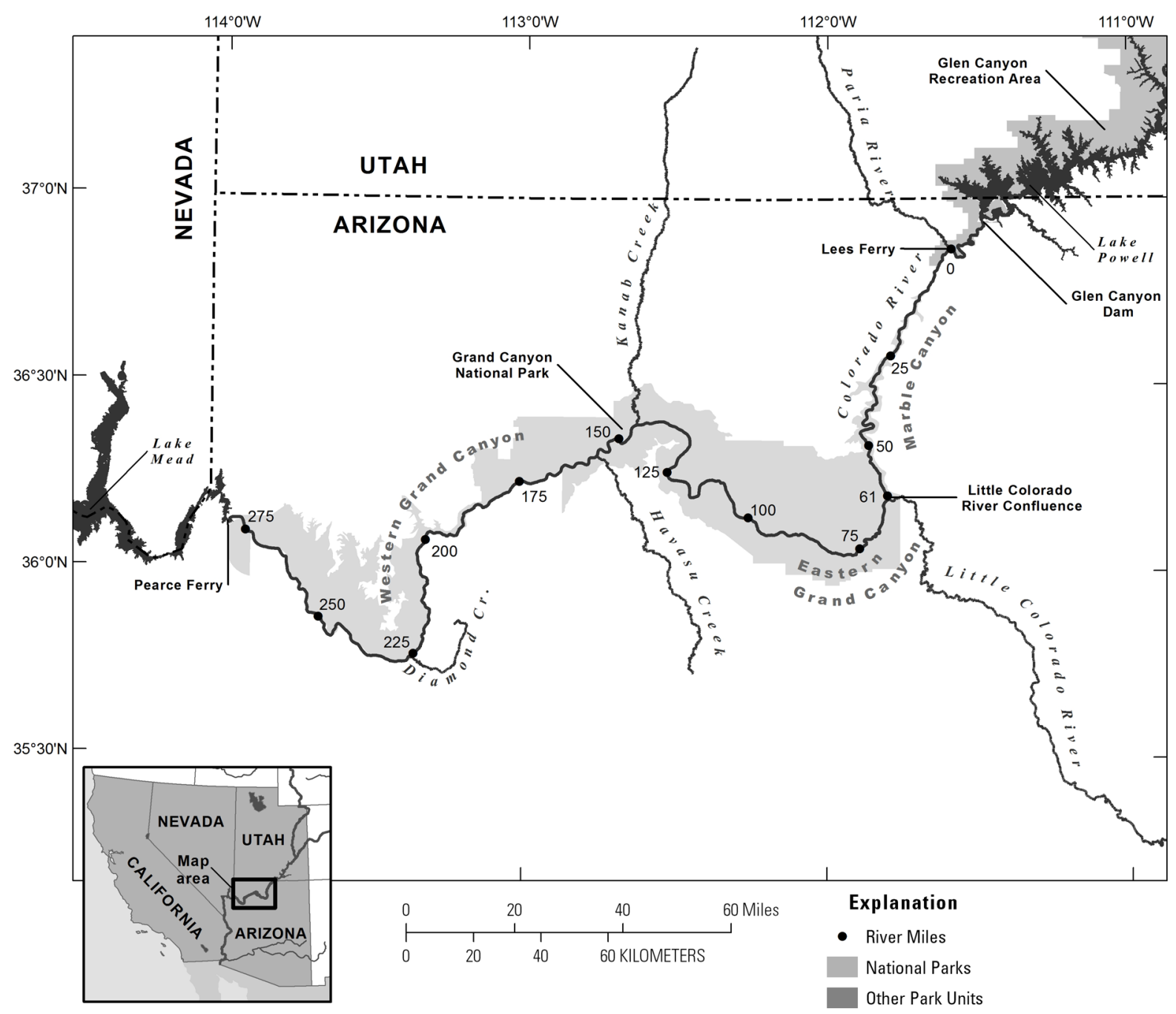

Figure 6-1. Map of the Colorado River downstream from Glen Canyon Dam. River mile (RM) designations occur at 25-mile intervals starting from Lees Ferry, designated as RM 0 . Large tributaries to the mainstem, including the Little Colorado River, are identified.

\section{Patterns of Standing Mass and Drift Concentrations of Periphyton, Macrophytes, and Benthic Organisms during the Low Steady Summer Flow Experiment}

Periphyton and macrophyte standing mass (grams ash-free dry mass per square meter $\left(\mathrm{AFDM} / \mathrm{m}^{2}\right)$ ) did not differ significantly between June 2000 and previous years (Rogers and others, unpub. report, 2003). The change in discharge between Periods I and II did not affect periphyton and macrophytes because they were established at depths below the $226 \mathrm{~m}^{3} / \mathrm{s}$ stage elevations. Densities and distributions of macrophytes and periphyton increased through Period II, reaching peaks in standing mass in July and August (figs. 6-2 and 6-3). Rogers and others (unpub. report, 2003) noted that the period during which periphyton reached its greatest standing mass was similar to previous years, whereas the pattern for macrophytes differed (July in 2000 
versus fall in the previous years). Rogers and others (unpub. report, 2003) attributed the shift in the peak for macrophyte density to a shift in the species composition from Chara sp. (a green alga) to pondweed (Potamogeton sp.) and leafy elodea (Egeria densa) that began following the 1996 HFE (McKinney and others, 1999; Benenati and others, 2001).

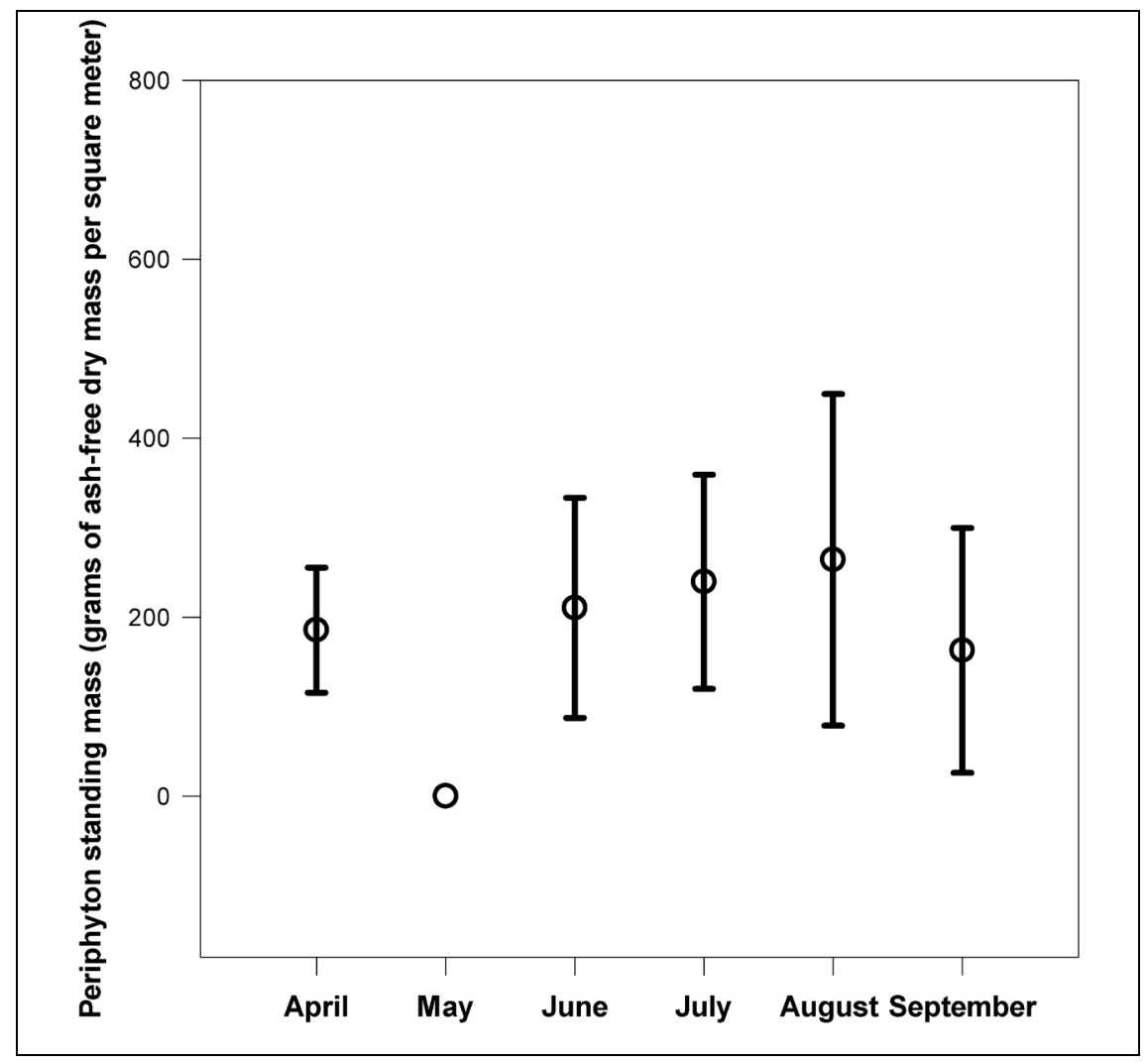

Figure 6-2. Mean standing mass of periphyton in the Lees Ferry reach of the Colorado River collected during the Low Steady Summer Flow Experiment at the $226 \mathrm{~m}^{3} / \mathrm{s}$ stage elevation in April, June, July, August, and September 2000. Sampling did not occur in May 2000. Error bars represent 95-percent confidence intervals. There were no statistically significant differences in biomass among sample periods. Data from Arizona Game and Fish Department (Rogers and others, unpub. report, 2003). 


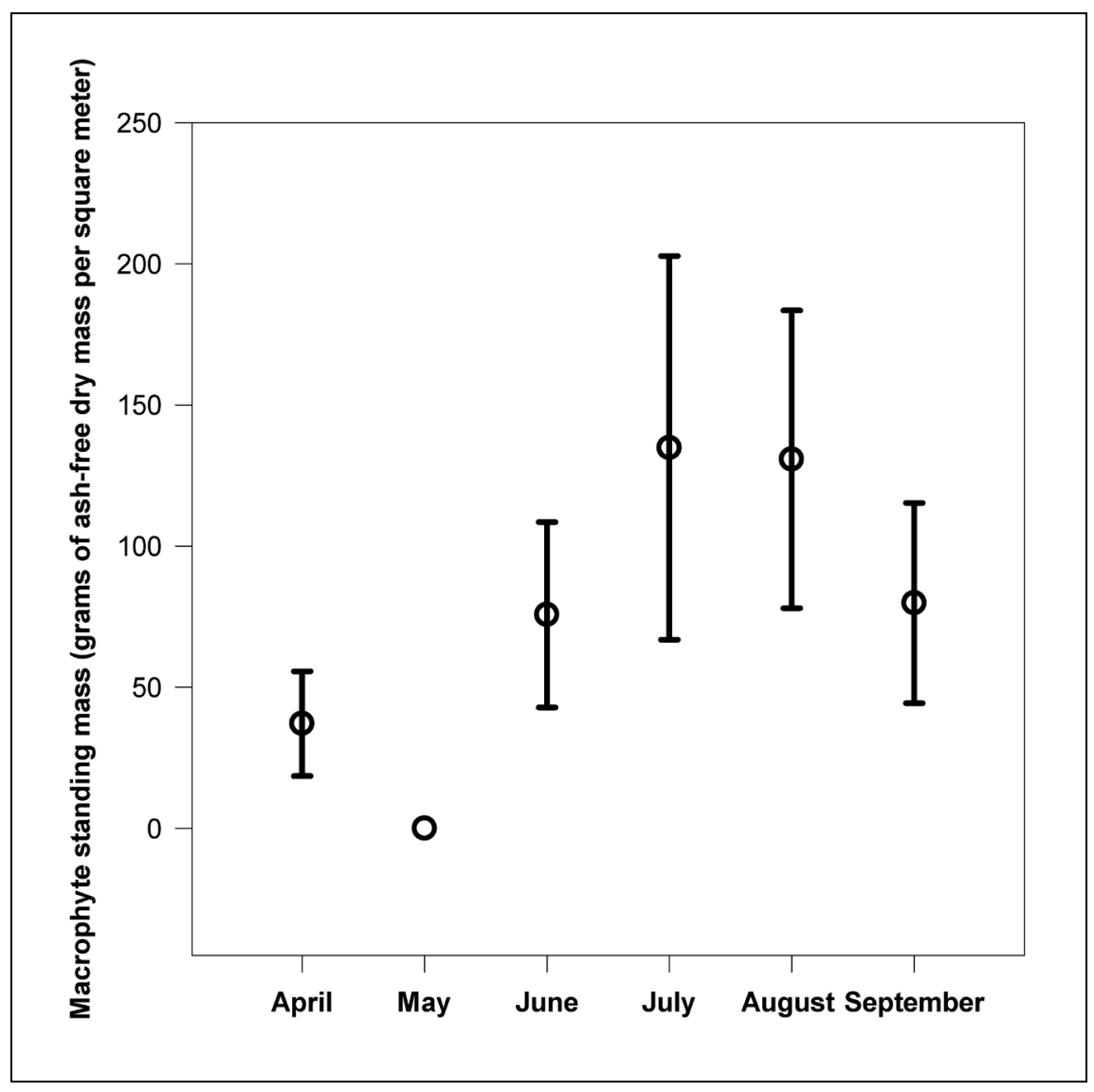

Figure 6-3. Mean standing mass of macrophytes in Lees Ferry collected at $226 \mathrm{~m}^{3} / \mathrm{s}$ stage elevation in April, June, July, August, and September 2000, during the Low Steady Summer Flow Experiment. Sampling did not occur in May 2000. Error bars represent 95-percent confidence intervals. Biomass was not statistically significantly different among sample periods. Data from Arizona Game and Fish Department (Rogers and others, unpub. report, 2003).

Rogers (unpub. report, 2003) compared the values for periphyton and macrophyte biomass from August 2000 during steady discharges with data from previous years during Modified Low Fluctuating Flow (MLFF) operations (McKinney and others, 1999). Comparisons for periphyton were limited to the years 1991 to 1993. Only a single year, 1997, was available for macrophyte comparisons. Ash-free dry mass values of periphyton collected in August 2000 using an integrated depth sample were approximately twice the average values recorded in August, 1991-93 (approximately $264.2 \mathrm{~g} \mathrm{AFDM} / \mathrm{m}^{2}$ in August 2000 versus $112.9 \mathrm{~g} \mathrm{AFDM} / \mathrm{m}^{2}$ in August, 1991-93; fig. 6-4). Macrophyte biomass values were similar between years (130.7 g $\mathrm{AFDM} / \mathrm{m}^{2}$ in August 2000 versus $114.2 \mathrm{~g} \mathrm{AFDM} / \mathrm{m}^{2}$ in August 1997; fig. 6-5). Increased discharge during 1994-96 also increased the wetted perimeter in the Glen Canyon reach and contributed to a greater standing mass for macrophytes (Rogers and others, unpub. report, 2003). The higher discharges in the late 1990s that cropped submerged algae and macrophytes may have contributed to comparable values of standing mass to those recorded in 2000. The stabilized habitat associated with the prolonged steady flows in June 2000 may have expanded growth and increased standing mass in periphyton and macrophytes (Rogers and others, unpub. report, 2003; Melis and others, unpub. report, 2006b). 


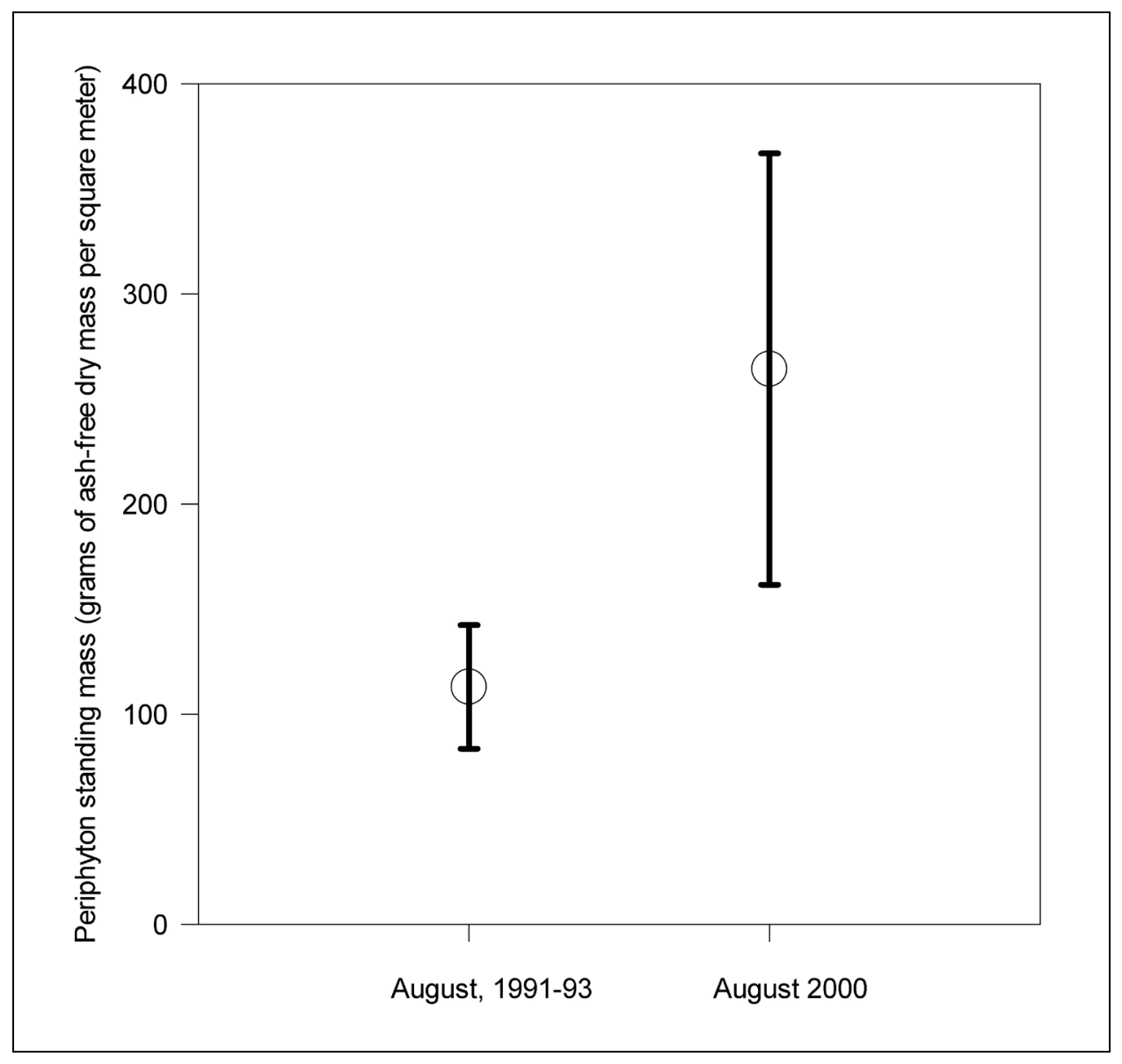

Figure 6-4. Comparison of mean standing mass of periphyton collected in the Lees Ferry reach of the Colorado River at the $226 \mathrm{~m}^{3} / \mathrm{s} \mathrm{stage} \mathrm{elevation} \mathrm{in} \mathrm{August} \mathrm{1991-93} \mathrm{and} \mathrm{2000.} \mathrm{Biomass} \mathrm{was} \mathrm{greater} \mathrm{in}$ August 2000 (statistically significant at $p<0.05$ ). Error bars represent 95 -percent confidence intervals about the mean. Data from Arizona Game and Fish Department (Rogers and others, unpub. report, 2003).

75 


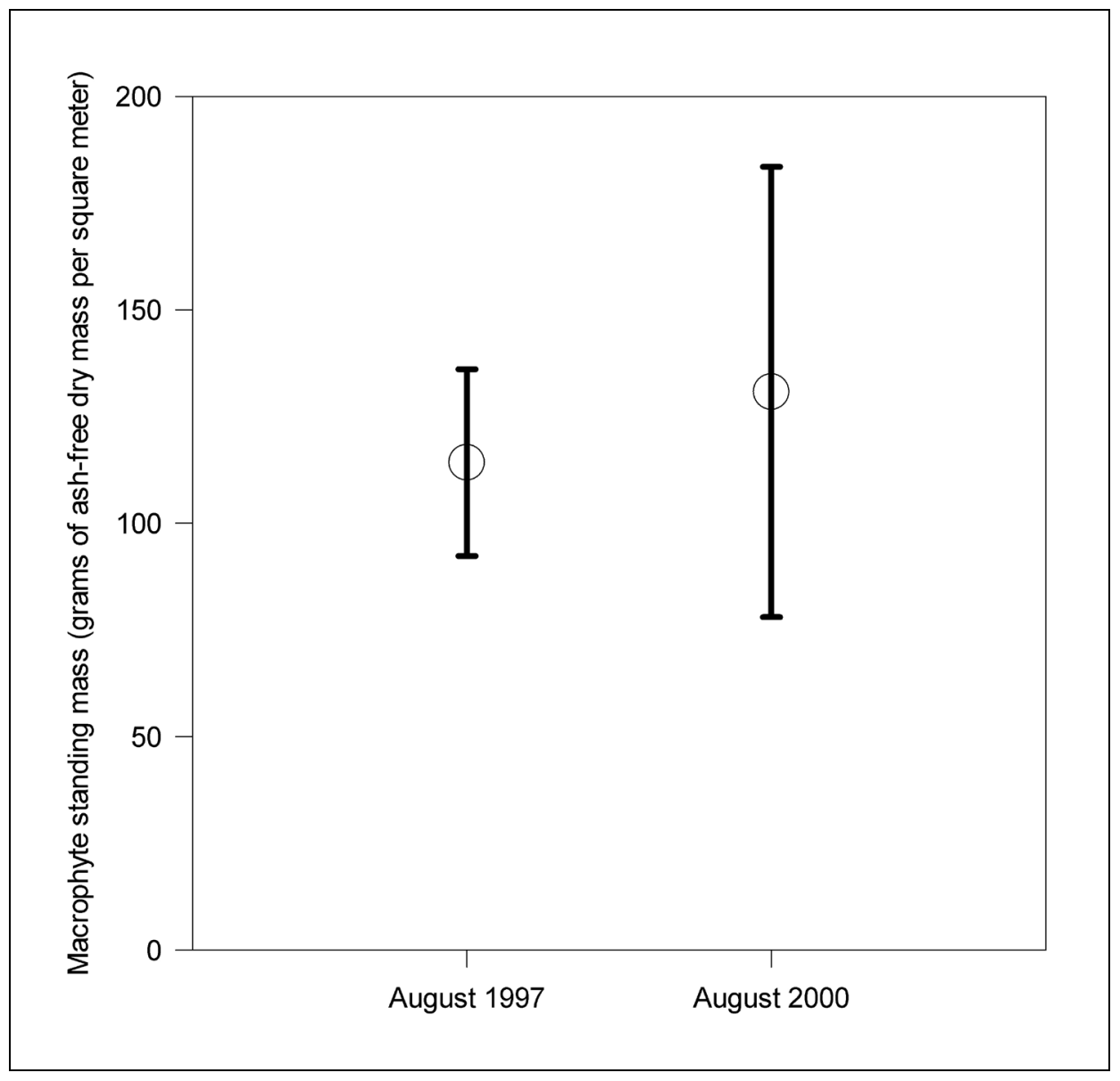

Figure 6-5. Comparison of mean standing mass of macrophytes in the Lees Ferry reach of the Colorado River collected at the $226 \mathrm{~m}^{3} / \mathrm{s}$ stage elevation in August 1997 and 2000 . There is no statistically significant difference in standing mass between the two periods. Error bars represent 95-percent confidence intervals. Data from Arizona Game and Fish Department (Rogers and others, unpub. report, 2003).

Comparison of benthic invertebrate densities of scuds, midges, and New Zealand mudsnails (Potamopyrgus antipodarum) during the LSSF experiment with previous years revealed that densities were equal to or greater than densities in previous years (Rogers and others, unpub. report, 2003). The timing of peak standing mass varied for some species compared with previous years. Scud densities in 2000 peaked in September as in previous years (Rogers and others, unpub. report, 2003) and were comparable to densities in 1992-97 (McKinney and others, 1999; figs. 6-6 and 6-7). The peak of midge densities occurred in July of 2000 (fig. 6-8), but midges peaked in the springtime in previous years (McKinney and others, 1999). Midge densities were two to three times greater in 2000 compared to 1992-97 (fig. 6-9; $5,000-9,000 \mathrm{midges} / \mathrm{m}^{2}$ in July 2000 versus $1,800-2,200 \mathrm{midges} / \mathrm{m}^{2}$ in the spring of 1992-97; Rogers and others, unpub. report, 2003). Lastly, gastropod densities were the greatest recorded in 2000 compared to previous years $\left(4,000-16,000\right.$ gastropods $/ \mathrm{m}^{2}$ in summer 2000 versus $200-400$ gastropods $/ \mathrm{m}^{2}$ in summer and fall of 1992-97 (Rogers and others, unpub. report, 2003). The historical values include the period before the first observation of New Zealand mudsnail in the Lees Ferry reach in 1995 (Shannon and others, unpub. report, 2003). The other year associated 
with greater gastropod densities was 1997, which was associated with a summer of high, steady discharges (Pulwarty and Melis, 2001). Gastropod densities in 1997 varied between 400 and 1,200 gastropods $/ \mathrm{m}^{2}$ (Rogers and others, unpub. report, 2003) suggesting steady discharges support higher snail densities than fluctuating discharges.

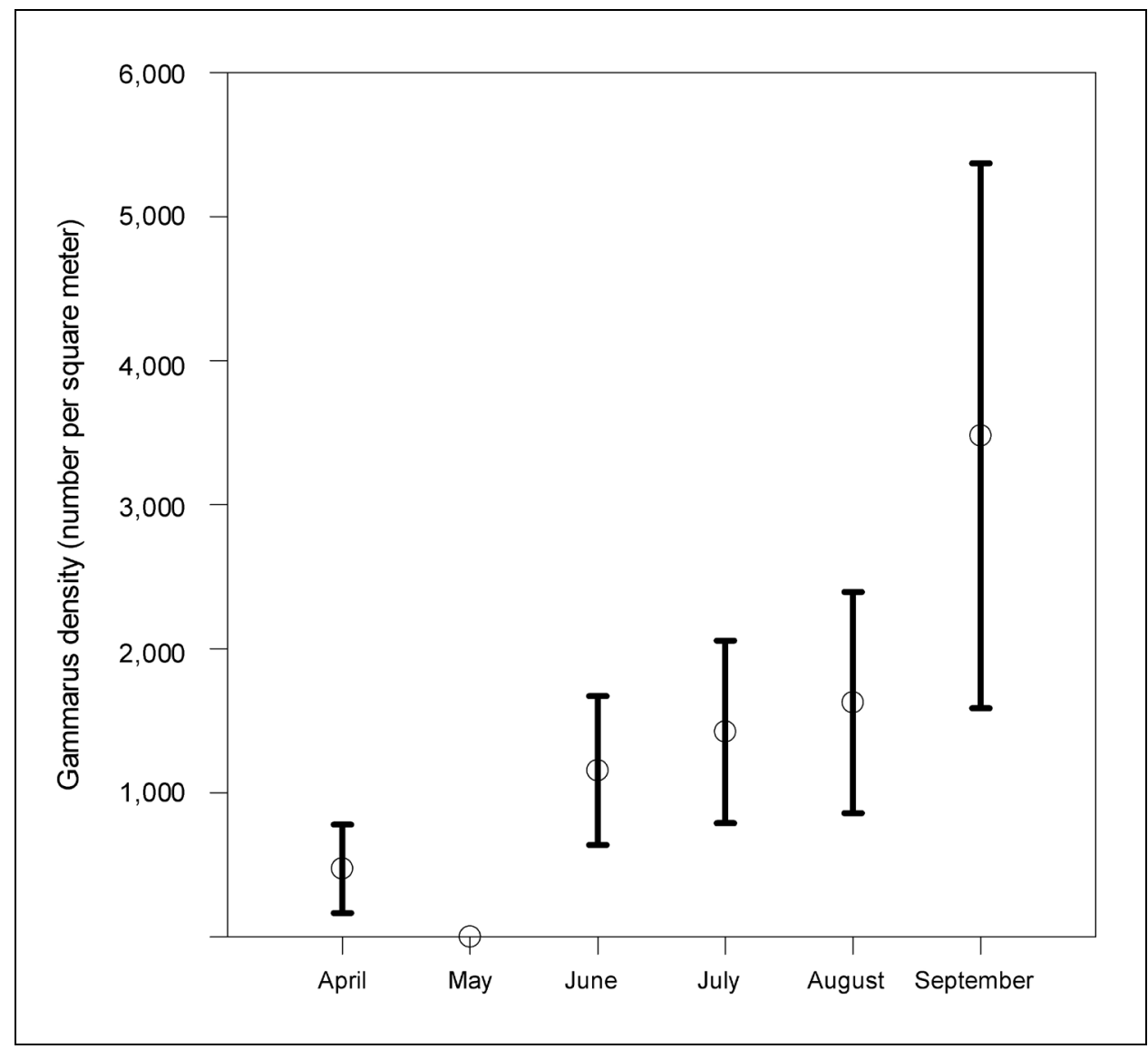

Figure 6-6. Mean densities of Gammarus in the Lees Ferry reach of the Colorado River in April, June, July, August, and September 2000. Sampling did not occur in May 2000. Error bars represent 95-percent confidence intervals. Data from Arizona Game and Fish Department (Rogers and others, unpub. report, 2003). 


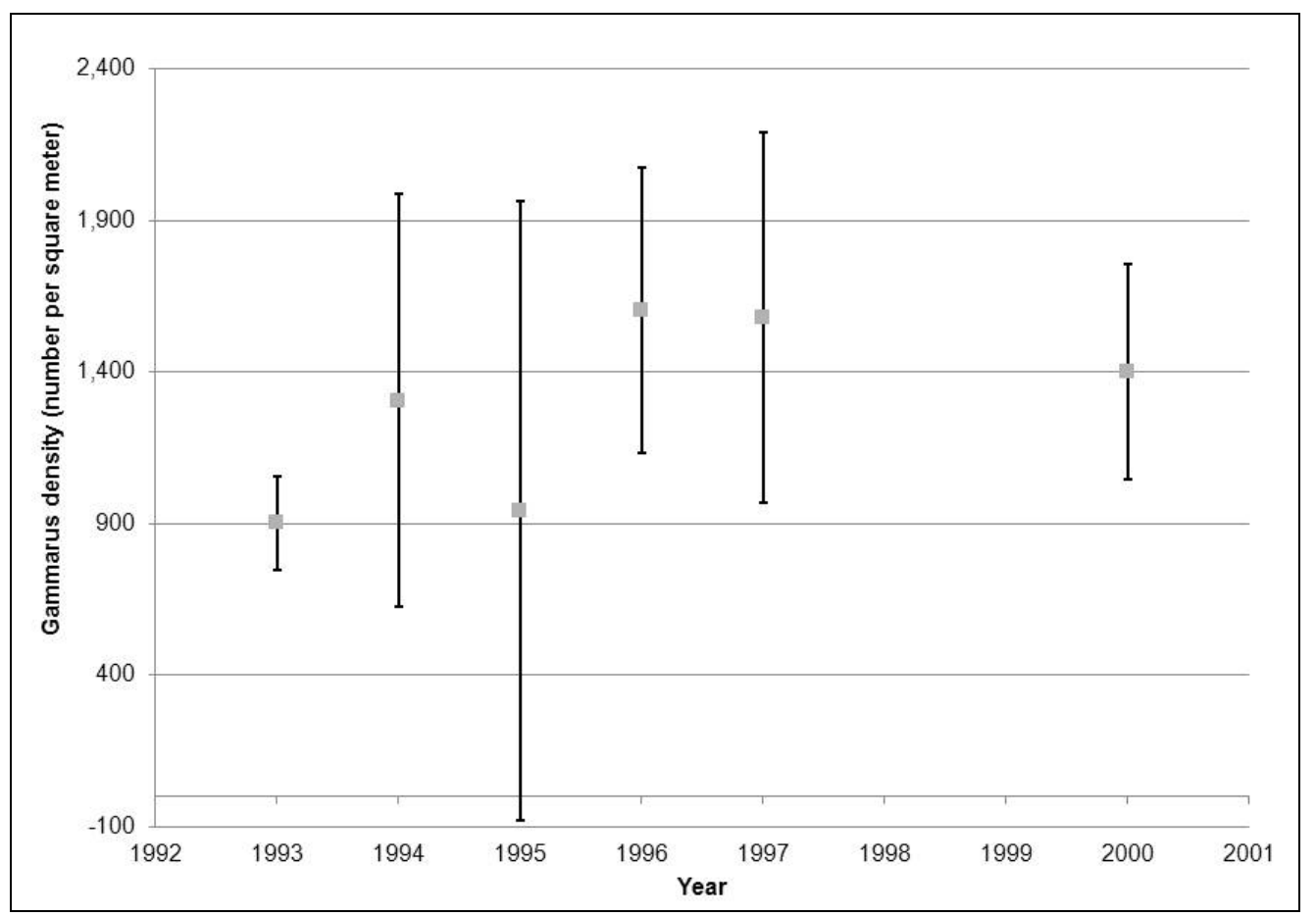

Figure 6-7. Mean densities of Gammarus in the Lees Ferry reach of the Colorado River during the summer months (June through August) in 1993-97 and 2000. Error bars represent 95-percent confidence intervals. Data from Arizona Game and Fish Department (Rogers and others, unpub. report, 2003).

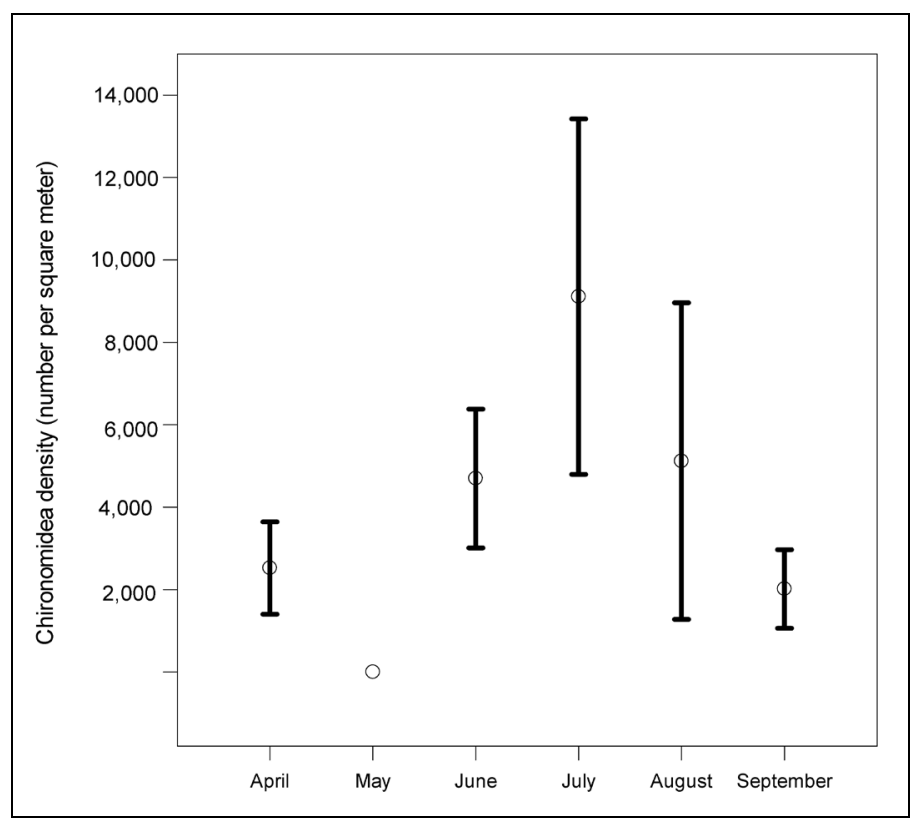

Figure 6-8. Mean densities of Chironomidea in the Lees Ferry reach of the Colorado River in April, June, July, August, and September 2000. Sampling did not occur in May 2000. Error bars represent 95-percent confidence intervals. Data from Arizona Game and Fish Department (Rogers and others, unpub. report, 2003). 


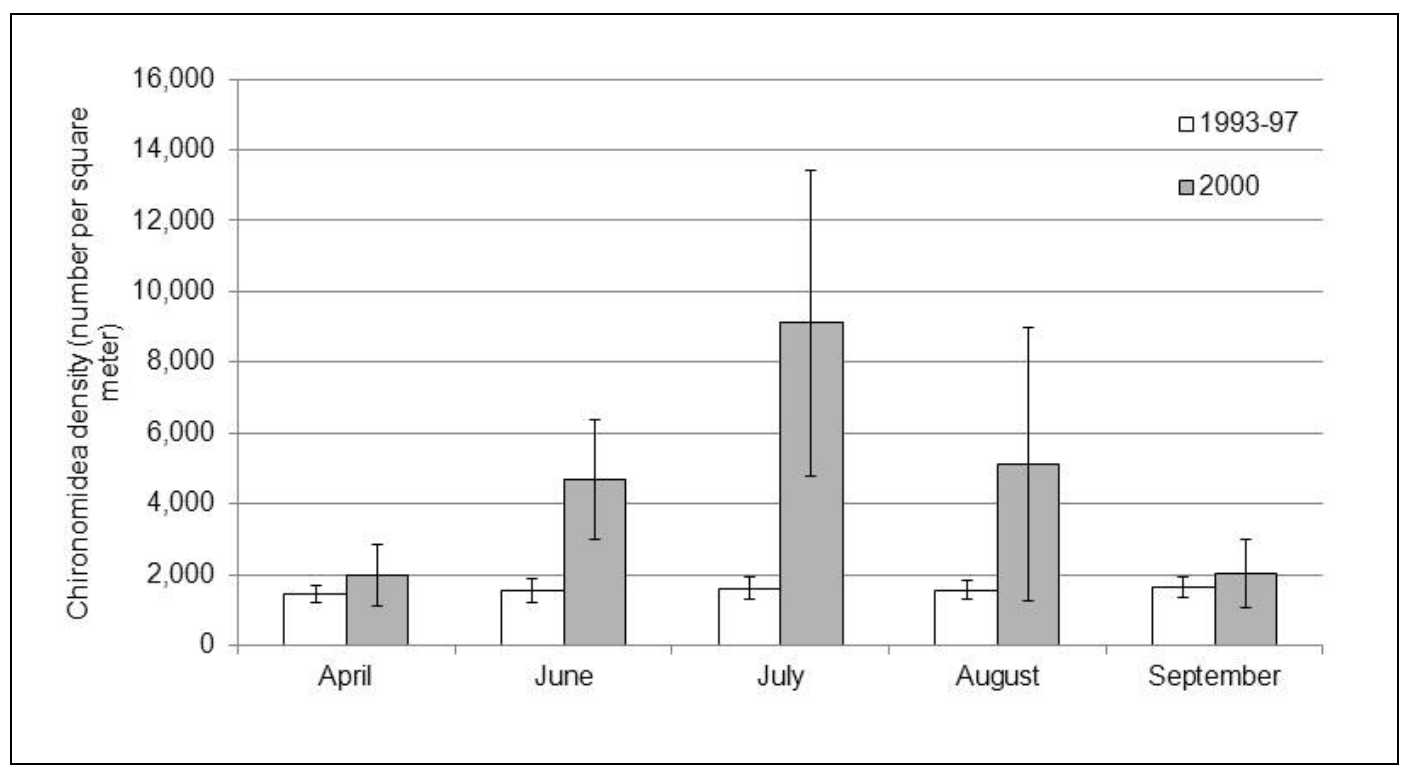

Figure 6-9. Mean densities of Chironomidae in the Lees Ferry reach of the Colorado River in April, June, July, August, and September 1993-97 and 2000. Error bars represent 95-percent confidence intervals. Data from Arizona Game and Fish Department (Rogers and others, unpub. report, 2003).

In 2000, peak drift concentrations of chironomids shifted from June to July compared to 1994. In 1994, drift concentrations peaked in June and averaged $0.10 \mathrm{~g}$ AFDM $/ \mathrm{m}^{2}$ (Rogers and others, unpub. report, 2003). In 2000, drift concentrations increased in July and were at values that were comparable to or exceeded previous years' values for the same month (approximately $0.08 \mathrm{~g} \mathrm{AFDM} / \mathrm{m}^{2}$ in July 2000 versus $0.05 \mathrm{~g}$ AFDM/m² in July 1993 and 1994 (Rogers and others, unpub. report, 2003). The differences in drift concentrations between these years may be associated with the typically larger discharges in June before 2000 during MLFF operations to meet power demands (Korman and others, 2004) compared to April and May 2000 during the LSSF experiment. Drift concentrations can increase on the increasing limb of discharges (Leibfreid and Blinn, 1987; Melis and others, unpub. report, 2006b) and decline on the decreasing limb, which might explain why drift concentrations peaked in June 1994 but reached a minimum in June 2000.

Shannon and others (2001) studied invertebrate density and drift concentrations during high, steady flows in 1997, and suggested that steady flows might produce greater densities, which leads to comparably greater drift concentrations. The 1-month lag in drift concentrations in 2000 (Rogers, and others, unpub. report, 2003) may lend support to the conclusions reached by Shannon and others (2001). The greater density of chironomids in July 2000 compared with previous years (Rogers and others, unpub. report, 2003) supports the hypothesis that steady flows increase invertebrate density.

Scud concentrations in the drift were greatest during the increased discharge associated with the May habitat maintenance flow (HMF), which supports the findings of Leibfried and Blinn (1987), whereas concentrations of midges in the drift were greatest immediately following the HMF during a steady release of $495 \mathrm{~m}^{3} / \mathrm{s}$. These increased drift concentrations of scuds and midges would have been coincident with adult fish moving off redds and actively feeding on drift. The relative condition, a measure of the weight-length relation or "plumpness," of fish in the spring of 2000 was greater than or equal to their relative condition in 1991-99, which 
includes years when fish were at their greatest relative condition before 2000 (Speas and others, unpub. report, 2004). The increased concentrations of scuds and midges in the spring of 2000 associated with the high flows and HMF during the same year may have contributed to the greater relative condition of fish in the spring of 2000 (McKinney and others, 1999; Speas and others, unpub. report, 2004).

Speas and others (unpub. report, 2004) determined that the mean relative gut volume of scuds in all rainbow trout in 2000 was the greatest since 1997, but Cladophora and midge values were lower in 2000. In the spring, the mean value of scuds in guts varied by size classes of fish such that only fish less than or equal to $305 \mathrm{~mm}$ had greater numbers of scuds in their gut compared with previous years. By summer, the presence of scuds in fish of all sizes was greater than in previous years. The increased presence of scuds among fish through time may correspond with the increasing standing mass of scuds in 2000 (Rogers and others, unpub. report, 2003) and may indicate a switch in feeding behavior by trout to active foraging for larger prey items (Giroux and others, 2005). Additionally, the relative gut contents observed in 2000 may have been affected by drift patterns of the prey items. To avoid predation, Gammarus may actively drift at night (Cada and others, 1987; Douglas and others, 1994; Flecker, 1992), which coincided with sampling of fish but not with sampling of drift, which occurred during the day. In contrast to nocturnal drifting behavior of Gammarus, there also may have been more asynchrony associated with Cladophora concentrations in the water column during steady flows. The small standard error associated with the mean drift samples from the summer months in 2000, which was dominated by Cladophora (Rogers and others, unpub. report, 2003), may indicate the more consistent concentration of Cladophora in the water column during steady flows compared with benthic invertebrates.

\section{Effect of Low Steady Summer Flow Experiment on the Lees Ferry Trout Fishery}

Identifying the effects of the LSSF experiment on the rainbow trout fishery is complicated by the decline in the fishery that began in 1997 (McKinney and Speas, 2001; Makinster and others, 2011). The relative condition of the rainbow trout population peaked in 1994 and fell 10 percent by 1997 for rainbow trout greater that or equal to $305 \mathrm{~mm}$ (total length), although, the relative condition of fish less than or equal to $305 \mathrm{~mm}$ remained stable until 1997. The time period 1997-2000 was characterized by high abundance of small ( $\leq 305 \mathrm{~mm})$, juvenilesized fish, with few fish greater than or equal to $406 \mathrm{~mm}$. There was an associated decline in catch rates from anglers (McKinney and Speas, 2001). Declines in growth rates and relative condition were attributed to over-recruitment and density-dependent growth suppression as discharges reached a minimum in 2000 (McKinney and Speas, 2001; McKinney and others, 2001).

As outlined in the LSSF experimental plan (Valdez and others, unpub report, 2000), the timing and magnitude of high discharges affect survivorship of small-sized fishes, including early life stages of rainbow trout (Korman and others, 2010). Survivorship in early stages affects the subsequent recruitment into the adult population. The April and May period in the life history of rainbow trout in the Lees Ferry fishery is a period when spawning is declining, young fish are emerging (Korman and Campana, 2009), and adult fish are moving off redds and into riffles to feed. In 2000, the discharges before April and May were lower but were not at a discharge less than $141 \mathrm{~m}^{3} / \mathrm{s}$ that would expose redds and negatively affect spawning success (McKinney and 
others, 2001; Korman and Campana, 2009). Because spawning generally peaks in mid-March and fish emergence follows approximately 30 days later (Korman and others, 2005; Korman and Campana, 2009), fry that emerged in April and May were subject to the higher sustained flows during those months. High discharges like those of the May HMF can displace young fish (Korman and Campana, 2009; Korman, 2009).

Speas and others (unpub. report, 2004) determined that the catch per unit effort (CPUE) of age-0 fish $(\leq 152 \mathrm{~mm}$ ) was slightly greater in 2000 than 1999, but not greater than the previous 5 years. Sampling by electrofishing in the spring of 2000 (Speas and others, unpub. report, 2004) indicated that age-0 fish appeared in the catch from April through June, 3 months earlier than in 1991-99. Speas and others (unpub. report, 2004) also reported greater numbers of fish with total lengths between 50 and $75 \mathrm{~mm}$ in 2000 than in previous years. The higher discharges in the April and May period as well as the HMF may have displaced some fish larvae, but there may have been a compensatory survival rate among fish that emerged later (Korman, 2009). The fact that the CPUE of YOY did not change between the end of June and the end of September 2000 may be an indication of compensatory survival.

The higher spring discharges and the May HMF also may have cleared interstitial spaces in the riverbed (Korman, 2009) that can serve as refuges for young fish. The May and September 2000 HMF moved sediment from eddies to mid-elevation sandbars (Hazel and others, 2006; Schmidt and others, 2007). Using side-scan sonar imagery for a section of river 2 miles downstream from Lees Ferry, Wong and others (2003) identified erosion of sediment from bedrock and coarsening of sand to pebbles and cobbles in association with the September HMF. They also identified deposition of sediment in shoreline areas downstream from Lees Ferry. The effect of the May HMF on sediment in the Glen Canyon reach, which is identified as a losing reach with respect to sediment (Grams and others, 2007), was erosion of sediment rather than deposition, including clearing of cobbles and gravels of finer sediment. The increased standing mass of Cladophora and benthic invertebrates, organisms that use hard substrates, suggests that the HMF evacuated sediment from the Glen Canyon reach.

The increased standing mass of algae macrophytes and benthic invertebrates in 2000 (Rogers and others, unpub. report, 2003) that provide cover and food for rainbow trout may have benefitted survival of YOY fish that emerged later in the season. The effect of the higher spring discharges and subsequent summer steady flows on YOY survivorship is speculative, however, because YOY survival of rainbow trout was not studied in 2000. Fish sampling conducted in 2001 in the Lees Ferry fishery (Speas and others, unpub. report, 2004) determined that the CPUE of age 2-3-year-old rainbow trout declined, as did the relative condition and proportional stock density of the fish. The decline in fish size and relative condition were attributed to reduced discharges, which limited food and habitat (McKinney and Speas, 2001).

\section{Angler Satisfaction}

February to May is a prime season for anglers at the Lees Ferry trout fishery. The effect on anglers of the higher discharges in April and May of 2000 and the HMF was a disruption in upstream access during the 4 days of the HMF (Hjerpe and Kim, unpub. report, 2003) and a loss in revenue for fishing guides. Given the decline of the fishery from 1997 to 2000, it is difficult to differentiate between the effects of the experiment and the general decline of the fishery on revenue. If the fishery had been in better condition, revenue loss may have been greater. The study of Hjerpe and Kim (unpub. report, 2003) did not identify if all available fishing guides were unable to work for those days, and the authors did not compare client numbers in 2000 with 
previous years when the fishery was in better condition. The lower steady flow period occurred at a time when fewer anglers visit the Lees Ferry fishery. The lower steady discharges should have provided easier access to anglers that fish from shorelines. The steady discharges created persistent habitats in which fish could feed and anglers could cast.

\section{Conclusions}

The LSSF experiment had little effect on the standing mass of either macrophytes or invertebrates in the Lees Ferry trout fishery. The exception was the standing mass of New Zealand mudsnail, which significantly expanded its density under steady discharges (Yard and Blinn, unpub. report, 2001; Rogers and others, unpub. report, 2003). The timing of the peak production for some of the food base was delayed. This delay may be attributed to the HMF in May that possibly scoured some benthos (Rogers and others, unpub. report, 2003). The condition of the Lees Ferry fishery before the LSSF experiment affects interpretation of the effect of the experiment on the resources in the Lees Ferry fishery. The condition of rainbow trout in the fishery was declining before the 2000 experiment and continued to decline following the experiment (Speas and others, unpub. report, 2004). The steady increase in food availability throughout the summer months may have benefitted all fish until the HMF in September 2000. The effect of the fall HMF on small fish may have been displacement, as was observed during subsequent high flows (Korman and Campana, 2009; Korman and others, 2010), though displacement was not studied in 2000. The number of small fish caught in the following year was similar to that in previous years (Speas and others, unpub. report, 2004) and suggests that large numbers of small fish observed in 2000 were displaced by the fall HMF. The LSSF experiment negatively affected angler access during the May and September HMF, but provided stable fish habitat in the summer months that provided shoreline anglers with consistent access to cobble habitat near Lees Ferry (Hjerpe and Kim, unpub. report, 2003).

\section{References}

Benenati, E.P., Shannon, J.P., Hagan, J.S., and Blinn, D.W., 2001, Drifting fine particulate organic matter below Glen Canyon Dam in the Colorado River, Arizona: Journal of Freshwater Ecology, v. 16, no. 2, p. 235-248, accessed on August 23, 2011, at http://www.gcmrc.gov/library/reports/biological/Foodbase/Benenati2001.pdf.

Bishop, R.C., Boyle, K.J., Welsh, M.P., Baumgartner, R.M., and Rathbun, P.R., 1987, Glen Canyon Dam releases and downstream recreation - an analysis of user preferences and economic values: Washington, D.C., Huberlein-Baumgartner Research Service, submitted to Bureau of Reclamation, Upper Colorado Region, Glen Canyon Environmental Studies, contract no. 4-CS-40-01780, technical report no. GCES/27/87, 398 p.

Blinn, D.W., Shannon, J.P., Stevens, L.E., and Carder, J.P., 1995, Consequences of fluctuating discharge for lotic communities: Journal of the North American Benthological Society, v. 14, no. 2, p. 233-248, accessed on December 2, 2010, at http://www.jstor.org/stable/pdfplus/1467776.pdf.

Cada, G.F., Loar, J.M., and Cox, D.K., 1987, Food and feeding preferences of rainbow and brown trout in southern Appalachian streams: American Midland Naturalist, v. 117, no. 2, p. 374-385, accessed on August 23, 2011, at http://www.jstor.org/stable/2425980. 
Douglas, P.L., Forrester, G.E., and Cooper, S.D., 1994, Effects of trout on the diel periodicity of drifting in baetid mayflies: Oecologia, v. 98, no. 1, p. 48-56, accessed on August 23, 2011, http://www.springerlink.com/content/n16h030271224860/.

Fisher, M.R., 1997, Segmentation of the angler population by catch preference, participation, and experience - a management-oriented application of recreation specialization: North American Journal of Fisheries Management, v. 17, no. 1, p. 1-10, accessed on August 23, 2011, at http://www.tandfonline.com/doi/abs/10.1577/1548-

8675(1997)017\%3C0001\%3ASOTAPB\%3E2.3.CO\%3B2.

Flecker, A.S., 1992, Fish predation and the evolution of invertebrate drift periodicity-evidence from neotropical streams: Ecology, v. 73, no. 2, p. 438-448, accessed on July 25, 2011, at http://www.jstor.org/stable/1940751.

Giroux, F., Ovidio, M., Phillippart, J.-C., and Baras, E., 2005, Relationship between the drift of macroinvertebrates and the activity of brown trout in a small stream: Journal of Fish Biology, v. 56, no. 5, p. 1248-1257, accessed on August 23, 2011, at http://onlinelibrary.wiley.com/doi/10.1111/j.1095-8649.2000.tb02137.x/abstract.

Grams, P.E., Schmidt, J.C., and Topping, D.J., 2007, The rate and pattern of bed incision and bank adjustment on the Colorado River in Glen Canyon downstream from Glen Canyon Dam, 1956-2000: Geological Society of America Bulletin, v. 119, no. 5-6, p. 556-575, accessed on July 19, 2011, at http://gsabulletin.gsapubs.org/content/119/5-6/556.abstract.

Hardwick, G.G., Blinn, D.W., and Usher, H.D., 1992, Epiphytic diatoms on Cladophora glomerata in the Colorado River, Arizona-longitudinal and vertical distribution in a regulated river: Southwestern Naturalist, v. 37, no. 2, p. 148-156, accessed on March 7, 2011, at http://www.jstor.org/stable/3671663.

Hazel, J.E., Jr., Topping, D.J., Schmidt, J.C., and Kaplinski, M., 2006, Influence of a dam on fine-sediment storage in a canyon river: Journal of Geophysical Research, v. 111, no. F01025, p. 1-16, accessed on December 28, 2009, at http://www.agu.org/journals/jf/jf0601/2004JF000193/2004JF000193.pdf.

Hjerpe, E., and Kim, Y.-S. 2003, Economic impacts of summer steady flows on recreation: Flagstaff, Northern Arizona University, School of Forestry, 21 p. [Available upon request by contacting the Center Director, U.S. Geological Survey, Southwest Biological Science Center, 2255 N. Gemini Drive, Flagstaff, Ariz. 86001.]

Korman, J., 2009, Early life history dynamics of rainbow trout in a large regulated river: Vancouver, University of British Columbia, Ph.D. dissertation, 233 p.

Korman, J., and Campana, S.E., 2009, Effects of hydropeaking on nearshore habitat use and growth of age-0 rainbow trout in a large regulated river: Transactions of the American Fisheries Society, v. 138, no. 1, p. 76-87, accessed on June 1, 2011, at http://www.tandfonline.com/doi/abs/10.1577/T08-026.1.

Korman, J., Kaplinski, M., Hazel, J.E.J., and Melis, T.S., 2005, Effects of the experimental fluctuating flows from Glen Canyon Dam in 2003 and 2004 on the early life history stages of rainbow trout in the Colorado River - final report: Ecometric Research, Inc., Northern Arizona University, and U.S. Geological Survey, submitted to U.S. Geological Survey, Grand Canyon Monitoring and Research Center, cooperative agreement no. 04-WRAG-0006 and modification no. 002, $171 \mathrm{p}$.

Korman, J., Wiele, S.M., and Torizzo, M., 2004, Modelling effects of discharge on habitat quality and dispersal of juvenile humpback chub (Gila cypha) in the Colorado River, Grand 
Canyon: River Research and Applications, v. 20, no. 4, p. 379-400, accessed on February 22, 2010, at http://www3.interscience.wiley.com/cgi-bin/fulltext/107614374/PDFSTART.

Korman, J., Yard, M., Walters, C.J., and Coggins, L.G., 2009, Effects of fish size, habitat, flow, and density on capture probabilities of age- 0 rainbow trout estimated from electrofishing at discrete sites in a large river: Transactions of the American Fisheries Society, v. 138, no. 1, p. 58-75, accessed on June 1, 2011, at http://www.tandfonline.com/doi/abs/10.1577/T08-025.1.

Korman, J., Kaplinski, M., and Melis, T.S., 2010, Effects of high-flow experiments from Glen Canyon Dam on abundance, growth, and survival rates of early life stages of rainbow trout in the Lees Ferry reach of the Colorado River: U.S. Geological Survey Open-File Report 20101034, 31 p., accessed on November 1, 2010, at http://pubs.usgs.gov/of/2010/1034/.

Leibfried, W.C., and Blinn, D.W., 1987, The effects of steady versus fluctuating flows on aquatic macroinvertebrates in Colorado River below Glen Canyon Dam, Arizona: Salt Lake City, Utah, Bureau of Reclamation, Glen Canyon Environmental Studies, Arizona Game and Fish Department contract no. 6400042, GCES/15/87. [Available from National Technical Information Service, Springfield, Va. as NTIS Report PB88-206362/AS.]

Makinster, A.S., Persons, W.R., and Avery, L.A., 2011, Status and trends of the rainbow trout population in the Lees Ferry Reach of the Colorado River downstream from Glen Canyon Dam, Arizona, 1991-2009: U.S. Geological Survey Scientific Investigations Report 20115015, 17 p., accessed on June 13, 2011, at http://pubs.usgs.gov/sir/2011/5015/.

McKinney, T., Rogers, R.S., and Persons, W.R., 1999, Effects of flow reductions on aquatic biota of the Colorado River below Glen Canyon Dam, Arizona: North American Journal of Fisheries Management, v. 19, no. 4, p. 984-991, accessed on August 19, 2011, at http://www.tandfonline.com/doi/abs/10.1577/1548-8675(1999)019\%3C0984:EOFROA\%3E2.0.CO;2

McKinney, T., and Speas, D.W., 2001, Observations of size-related asymmetries in diet and energy intake of rainbow trout in a regulated river: Environmental Biology of Fishes, v. 61, no. 4, p. 435-444, accessed on November 1, 2010, at http://www.springerlink.com/content/u177356554v07546/.

McKinney, T., Speas, D.W., Rogers, R.S., and Persons, W.R., 2001, Rainbow trout in a regulated river below Glen Canyon Dam, Ariz., following increased minimum flows and reduced discharge variability: North American Journal of Fisheries Management, v. 21, p. 216-222.

Melis, T.S., Wright, S.A., Ralston, B.E., Fairley, H.C., Kennedy, T.A., Andersen, M.E., and Coggins, L.G., Jr., 2006, 2005 knowledge assessment of the effects of Glen Canyon Dam on the Colorado River ecosystem — an experimental planning support document — final draft: Flagstaff, Ariz., U.S. Geological Survey, Grand Canyon Monitoring and Research Center, 88 p. [Available upon request by contacting the Center Director, U.S. Geological Survey, Southwest Biological Science Center, 2255 N. Gemini Drive, Flagstaff, Ariz. 86001.]

Petering, R.W., Isbell, G.L., and Miller, R.L., 1995, A survey method for determining angler preference for catches of various fish length and number combinations: North American Journal of Fisheries Management, v. 15, no. 4, p. 732-735, accessed on August 23, 2011, at http://www.tandfonline.com/doi/abs/10.1577/15488675(1995)015\%3C0732\%3AASMFDA\%3E2.3.CO\%3B2.

Pulwarty, R.S. and Melis, T.S., 2001, Climate extremes and adaptive management on the Colorado River-lessons from the 1997-1998 ENSO event: Journal of Environmental Management, v. 63, no. 3, p. 307-324, accessed on August 23, 2011, at http://www.sciencedirect.com/science/article/pii/S0301479701904943. 
Radomski, P.J., Grant, G.C., Jacobson, P.C., and Cook, M.F., 2001, Visions for recreational fishing regulations: Fisheries, v. 26, no. 5, p. 7-18, accessed on August 23, 2011, at http://www.tandfonline.com/doi/abs/10.1577/15488446(2001)026\%3C0007\%3AVFRFR\%3E2.0.CO\%3B2.

Rogers, R.S., Persons, W.R., and McKinney, T., 2003, Effects of a 31,000-cfs spike flow and low steady flows on benthic biomass and drift composition in the Lees Ferry tailwater: Arizona Game and Fish Department, cooperative agreement no. 1425-98-FC-22390, mod. 3, 26 p., accessed on August 23, 2011, at http:/www.gcmrc.gov/library/reports/biological/Foodbase/ Rogers2003b.pdf.

Schmidt, J.C., Topping, D.J., Rubin, D.M., Hazel, J.E., Jr., Kaplinski, M., Wiele, S.M., and Goeking, S.A., 2007, Streamflow and sediment data collected to determine the effects of low summer steady flows and habitual maintenance flows in 2000 on the Colorado River between Lees Ferry and Bright Angel Creek, Arizona: U.S. Geological Survey Open-File Report 20071268, 79 p., accessed on March 17, 2010, at http://pubs.usgs.gov/of/2007/1268/.

Shannon, J.P., Benenati, E.P., Kloeppel, H., Richards, D., 2003, Monitoring the aquatic food base in the Colorado River, Arizona during June and October 2002-annual report: Flagstaff, Ariz., U.S. Geological Survey, Grand Canyon Monitoring and Research Center, cooperative agreement no. 02WRAG0028, 50 p. [Available upon request by contacting the Center Director, U.S. Geological Survey, Southwest Biological Science Center, 2255 N. Gemini Drive, Flagstaff, Ariz. 86001.]

Shannon, J.P., Blinn, D.W., McKinney, T., Benenati, E.P., Wilson, K.P., and O'Brien, C., 2001, Aquatic food base response to the 1996 test flood below Glen Canyon Dam, Colorado River, Arizona: Ecological Applications, v. 11, no. 3, p. 672-685, accessed on January 11, 2010, at http://www.jstor.org/stable/3061109.

Speas, D.W., Persons, W.R., Rogers, R.S., Ward, D.L., Makinster, A.S., and Slaughter, J.E., IV, 2004, Effects of low steady summer flows on rainbow trout in the Lee's Ferry tailwater, 2000: Phoenix, Arizona Game and Fish, submitted to U.S. Geological Survey, Grand Canyon Monitoring and Research Center, cooperative agreement no. 1425-98-FC-40-22690, 38 p., accessed on August 23, 2011, at http://www.gcmrc.gov/library/reports/biological/Fish_studies/ AZGame\&Fish/2004/Speas2004.pdf.

Stevens, L.E., Shannon, J.P., and Blinn, D.W., 1997, Colorado River benthic ecology in Grand Canyon, Arizona, USA--dam, tributary, and geomorphological influences: Regulated Rivers-Research and Management, v. 13, no. 2, p. 129-149, accessed on December 1, 2010, at http://www3.interscience.wiley.com/cgi-bin/fulltext/11832/PDFSTART.

U.S. Department of the Interior, 1996, Record of Decision, Operation of Glen Canyon Dam Final Environmental Impact Statement: Washington, D.C., Office of the Secretary of Interior, 15 p.

Valdez, R.A., Carothers, S.W., House, D.A., Douglas, M.E., Ryel, R.J., Bestgen, K.R., and Wegner, D.L., 2000, A program of experimental flows for endangered and native fishes of the Colorado River in Grand Canyon-final report: Flagstaff, Ariz., SWCA, Inc., Environmental Consultants, submitted to U.S. Geological Survey, Grand Canyon Monitoring and Research Center, 68 p. [Available upon request by contacting the Center Director, U.S. Geological Survey, Southwest Biological Science Center, 2255 N. Gemini Drive, Flagstaff, Ariz. 86001.] Wong, F.L., Anima, R.J., Galanis, P., Codianne, J., Xia, Y., Bucciarelli, R., and Hamer, M., 2003, Grand Canyon riverbed sediment changes - experimental release of September 2000 - a sample data set: U.S. Geological Survey Open-File Report 03-0265, 7 p., accessed on March 25, 2010, at http://geopubs.wr.usgs.gov/open-file/of03-265/. 
Yard, M.D., Blinn, D.W., 2001, Algal colonization and recolonization response rates during experimental low summer steady flows - final report: Flagstaff, Ariz., Northern Arizona University, submitted to U.S. Geological Survey, Grand Canyon Monitoring and Research Center, 60 p. [Available upon request by contacting the Center Director, U.S. Geological Survey, Southwest Biological Science Center, 2255 N. Gemini Drive, Flagstaff, Ariz. 86001.] 


\section{Chapter 7. Financial Costs Associated with the Low Steady Summer Flow Experiment}

\section{Introduction}

Economic studies associated with the Low Steady Summer Flow (LSSF) experiment were limited to the financial costs of the experiment to Federal power users (Palmer and others, unpub. report, 2004; Harpman and Douglas, 2005; Veselka and others, unpub. report, 2011), recreational businesses, and other businesses that support recreational businesses (for example, restaurants, motels) (Hjerpe and Kim, unpub. report, 2003). Financial cost associated with the Glen Canyon Dam and the Colorado River include the cost of purchasing power to meet daily electrical demands and revenues and jobs associated with the recreational and tourism industries (Harpman and Douglas, 2005). Several elements of the LSSF hydrograph contributed to the financial costs to power users and recreational businesses.

When and how much water was released, how water was reallocated to accommodate the experiment, the steady release pattern, and uncontrollable nature of the power market all contributed to the financial costs of the experiment. The movement of monthly water allocations into early March and later into November 2000 to accommodate the lower monthly volumes in the summer affected water volumes available to generate power when it is in greatest demand (summer months). The sustained high flows in April and May and the habitat maintenance flow in May and September affected power production and recreational access in Glen Canyon. The reduced discharge in Period II reduced power-generating capacity, increased damage to boats traveling downstream, and initially increased rafting accidents (Jalbert, unpub. report, 2009). The drought and the associated energy crisis in California and the Western United States during the summer of 2000 (Federal Energy Regulatory Commission, 2003; Harpman and Douglas, 2005; Hjerpe and Kim, unpub. report, 2003; Korman and others, 2004) increased the demand for power and increased the cost of power. Lastly, energy market manipulation by some energy suppliers in 2000 (Federal Energy Regulatory Commission, 2003) also contributed to the inflated financial costs associated with the LSSF experiment.

\section{Financial Costs to Federal Power Users}

The Western Area Power Administration (Western) is a power marketing administration within the U.S. Department of Energy that sells power to preferred and non-preferred customers. Western is responsible for selling and delivering electricity that is in excess of Colorado River Storage Project (CRSP) use (power required to operate irrigation projects). Western sells power first to municipalities and public corporations or other organizations associated with the Rural Electrification Act of 1936 (Palmer and others, unpub. report, 2004; Harpman and Douglas, 2005). These entities constitute preferred customers. Non-preferred customers can purchase any excess power supply. Western purchases power on the daily market to meet demand of their preferred customers when power demands exceed Western's power supplies (Palmer and others, unpub. report, 2004). Because of the long-term relationship that exists between the Bureau of Reclamation and Western with respect to water delivery and power generation, the power 
generated from the CRSP hydroelectric dams is predictable. Western can identify when the purchase of supplemental power is required on the basis of the long-term average consumption of preferred customers. The predictability associated with water delivery, power generation, and preferred customer demand allows Western to purchase power in seasonal blocks at a firm price rather than at the daily price, which can vary depending on demand.

Western's costs began to increase for the experiment with the reallocation of water releases to alternate months to accommodate the 2000 LSSF experimental hydrograph. Monthly water allocations needed to be reapportioned by the Bureau of Reclamation, the agency responsible for water delivery along the Colorado River. To meet water-delivery requirements associated with the Colorado River Compact signed in 1922, which guarantees delivery of 8.23 maf of water to the lower basin states (Arizona, California, Nevada, New Mexico) and Mexico, the Bureau of Reclamation released an extra 604,000 acre-ft of water from Glen Canyon Dam in early March 2000. This release occurred during a time of reduced power demand and contributed to the financial costs of the experiment because the water was not available to generate power in months of higher demand (Harpman and Douglas, 2005). The loss of potential power generation in 2000 presumably would be recovered in water year (WY) 2001 when inflows would return to those observed in the 1990s. The higher releases in WY 2001, particularly if the releases occurred in the summer months would compensate for the excess water released in March 2000 during lower power demand. Unfortunately, the low snowpack and associated runoff forecast that began in WY 2000 that initiated LSSF experiment continued through the next decade and equalization did not occur until the spring of 2011. The extra water releases in March 2000 and the reallocation of water to November 2000 (another month associated with low power demand) are a financial cost that Western did not recover (Palmer and others, unpub. report, 2004).

The steady discharges during Period II reduced power-generating capacity, and Western was required to purchase power on the daily market. At the same time, the drought and extreme heat in the Southwest and West increased power demand in the region and caused the cost of power to increase substantially. Because of the short notice associated with implementing the LSSF experiment, Western could not anticipate the need to purchase additional power beyond the usual seasonal block approach traditionally used (Palmer and others, unpub. report, 2004). The short notice associated with the implementation of the experimental plan affected planning for power purchases and the drought increased power demands, which, in turn, increased the spot market price; these factors contributed to the financial cost of the experiment.

The combined effect of shifting water releases to alternate months and reduced powergeneration capacity in the summer of 2000 for the LSSF experiment resulted in estimated financial costs to Federal power users of approximately \$32 million (2000 dollars; Palmer and others, unpub. report, 2004; Harpman and Douglas, 2005). Revised financial analysis (Veselka and others, unpub. report, 2011) reduced the final costs to $\$ 26.4$ million from $\$ 32$ million. The cost estimate was reduced because the experimental releases in WY 2000 (HMFs) resulted in a $\$ 410,000$ in increased power revenue, which reduced the overall cost of the LSSF experiment (Veselka and others, unpub. report, 2011).

\section{Financial Costs to Recreation}

The LSSF experiment incurred some financial costs to whitewater rafting companies operating downstream from Lees Ferry and fishing guides operating in Glen Canyon (Hjerpe and Kim, unpub. report, 2003), but the two groups were affected by different parts of the hydrograph. The LSSF hydrograph did not affect day rafting in Glen Canyon because discharge rates do not 
affect this recreational industry (Bishop and others, 1987). The May and September habitat maintenance flows (HMFs) affected fishing guides in Glen Canyon by limiting upstream access. The fishing guides did not operate for 4 days in May and September (Hjerpe and Kim, unpub. report, 2003). Fishing guides reported a combined loss of $\$ 33,000$ because of an inability to conduct trips (Hjerpe and Kim, unpub. report, 2003). Because the fall HMF occurred during a holiday weekend in September, the loss of business may have been greater than if the HMF had occurred during the week or later in the month. Throughout the summer months, the fishing guides reported improved fishing; however, the increase in business was proportional to increases in the previous 5 years and could not be attributed conclusively to the LSSF experimental hydrograph (Hjerpe and Kim, unpub. report, 2003).

Financial costs to whitewater rafting companies occurred during Period II, which included lower discharges. Jalbert (unpub. report, 2009) identified several boating trips that experienced stranding in rapids and required rescue early in Period II. These boating incidents contributed to the loss or damage of rafting equipment and injury to passengers. Most equipment damage resulted in motor damage when propellers and motor units hit exposed rocks. Hjerpe and Kim (unpub. report, 2003) attribute some of the loss to equipment inflexibility: large commercial boats have difficulty maneuvering through some rapids at low water. However, these boats were used before changes in minimum discharges that occurred in 1996 (U.S. Department of the Interior, 1996), when discharge volumes fluctuated between 84 and $877 \mathrm{~m}^{3} / \mathrm{s}$ daily. It is more likely that boat operators were unaccustomed to the lower discharges and their inexperience contributed to equipment damage. As time passed, boat stranding decreased, suggesting that boat operators learned to avoid exposed rocks (Jalbert, unpub. report, 2009).

Increased fuel costs associated with boats moving slower during low discharges and requiring more motor support (Roberts and Bieri, unpub. report, 2001) also contributed to costs. The cost of personal injury and the reimbursement of trip costs to commercial passengers because of evacuation were other costs incurred by whitewater rafting companies. Hjerpe and Kim (unpub. report, 2003) estimated that the total regional cost of the LSSF was $\$ 124,000$ (1998 dollars), including $\$ 70,000$ for the combined costs to whitewater rafting companies (for example, damaged equipment and customer refunds) and a total expenditure of $\$ 30,000$ by the National Park Service to evacuate stranded rafting trips. This estimate does not include the financial impacts to businesses such as lodging, health care, and restaurants that benefit from recreational economic activity that may have been affected by the experiment.

\section{Conclusions}

The LSSF experiment resulted in substantial financial costs to Federal power users and local businesses directly related to Colorado River resources (Hjerpe and Kim, unpub. report, 2003; Palmer and others, unpub. report, 2004; Harpman and Douglas, 2005; Veselka and others, unpub. report, 2011). The Bureau of Reclamation's need to implement the LSSF experiment to meet the requirement's of the Biological Opinion issued by the U.S. Fish and Wildlife Service in a short period of time reduced Western's ability to purchase additional power in seasonal blocks that might have reduced the financial costs of the experiment. Instead, Western had to purchase power on the daily market, which was subject to unforeseen price manipulations by power suppliers (Federal Energy Regulatory Commission, 2003). The timing of the HMF for a holiday weekend may have had a greater effect on fishing guides than if it occurred in the middle of the week. On the basis of the responses by fishing guides to queries during the summer of 2000, it appeared that trout in the Lees Ferry reach were not affected by the high spring flows (Hjerpe 
and Kim, unpub. report, 2003). Evaluating only the financial costs of the LSSF experiment limits the understanding of the total economic costs and benefits of the experiment.

\section{References}

Bishop, R.C., Boyle, K.J., Welsh, M.P., Baumgartner, R.M., and Rathbun, P.R., 1987, Glen Canyon Dam releases and downstream recreation - an analysis of user preferences and economic values: Washington, D.C., Huberlein-Baumgartner Research Service, submitted to Bureau of Reclamation, Upper Colorado Region, Glen Canyon Environmental Studies, contract no. 4-CS-40-01780, technical report no. GCES/27/87, 398 p.

Federal Energy Regulatory Commission, 2003, Final report on price manipulation in western markets, fact-finding investigation of potential manipulation of electric and natural gas prices: Department of Energy, Federal Energy Regulatory Commission, docket no. PA02-2-000, 189 p., accessed on August 23, 2011, at http://www.ferc.gov/legal/maj-ord-reg/land-docs/PART-I3-26-03.pdf.

Harpman, D.A., and Douglas, A.J., 2005, Status and trends of hydropower at Glen Canyon Dam, in Gloss, S.P., Lovich, J.E., and Melis, T.S., eds., The state of the Colorado River ecosystem in Grand Canyon: U.S. Geological Survey Circular 1282, 165-176 p., accessed on May 10, 2010, at http://pubs.usgs.gov/circ/1282/.

Hjerpe, E., and Kim, Y.-S. 2003, Economic impacts of summer steady flows on recreation: Flagstaff, Northern Arizona University, School of Forestry, 21 p. [Available upon request by contacting the Center Director, U.S. Geological Survey, Southwest Biological Science Center, 2255 N. Gemini Drive, Flagstaff, Ariz. 86001.]

Jalbert, L.M., 2009, The effects of the 2000 Low Steady Summer Flows on observed and reported boating accidents on the Colorado River in Grand Canyon National Park. Final report from Grand Canyon National Park to U.S. Geological Survey, Grand Canyon Monitoring and Research Center, Flagstaff, Ariz., 25 p. [Available upon request by contacting the Center Director, U.S. Geological Survey, Southwest Biological Science Center, 2255 N. Gemini Drive, Flagstaff, Ariz. 86001.]

Korman, J., Wiele, S.M., and Torizzo, M., 2004, Modelling effects of discharge on habitat quality and dispersal of juvenile humpback chub (Gila cypha) in the Colorado River, Grand Canyon: River Research and Applications, v. 20, no. 4, p. 379-400, accessed on February 22, 2010, at http://www3.interscience.wiley.com/cgi-bin/fulltext/107614374/PDFSTART.

Palmer, S.C., Burbidge, C., and Patno, H., 2004, The financial impacts of the low summer steady flow experiment at Glen Canyon Dam: Salt Lake City, Utah, U.S. Department of Energy, Western Area Power Administration, CRSP Management Center, 32 p., accessed on August 23, 2011, at http://www.gcmrc.gov/library/reports/Other/GlenCanyonDam/Palmer2004b.pdf. Roberts, C.A., and Bieri, J.A., 2001, Impacts of low flows on recreational rafting traffic on the Colorado River in Grand Canyon National Park-final report: Flagstaff, Ariz., submitted to Bureau of Reclamation and U.S. Geological Survey, Grand Canyon Monitoring and Research Center, cooperative agreement no. CA8210-99-002, interagency acquisition no. 00-AA-404330, 18 p., accessed on August 23, 2011, at http://www.gcmrc.gov/library/reports/cultural/Recreation/roberts2001.pdf.

U.S. Department of the Interior, 1996, Record of Decision, Operation of Glen Canyon Dam Final Environmental Impact Statement: Washington, D.C., Office of the Secretary of Interior, 15 p. 
Veselka, T.D., Poch, L.A., Palmer, C.S., Loftin, S., and Osiek, B., 2011, Revised financial analysis of experimental releases conducted at Glen Canyon Dam during water years 1997 through 2005: U.S. Department of Energy, Western Area Power Administration, ANL/DIS-111, 83 p., accessed on August 10, 2011, at www.ipd.anl.gov/anlpubs/2011/01/68980.pdf. 
This page intentionally left blank 


\section{Chapter 8. Management Implications Associated with the Low Steady Summer Flow Experiment}

\section{Introduction}

The purpose of the Low Steady Summer Flow (LSSF) experiment was to evaluate factors that limit the growth and survival of young native fish (for example, habitat stability and water temperatures). Spring and summer operations of Glen Canyon Dam were altered in 2000 to mimic seasonal hydrology that might benefit native fish more than Modified Low Fluctuating Flow (MLFF) operations. It was presumed that mimicking elements of the predam hydrograph (for example, high releases in the spring and low releases in the summer that did not fluctuate) would present more hospitable habitats for native fish than MLFF operations and increase young fish survival, growth, and subsequent recruitment.

Knowledge gained by fishery and physical resource studies executed during the LSSF experiment are reviewed in the context of the hypotheses that were generated by Valdez and others (unpub report, 2000; table 8-1). The responses of other resources not identified by Valdez and others (unpub. report, 2000) to the LSSF experiment appear in table 8-2. The last column in tables 8-1 and 8-2 provides a rating (for example, good, fair, poor, and inconclusive) of the effectiveness of a study to assess the resource response to the LSSF hydrograph. In general, the responses of physical resources to the LSSF experimental hydrograph were adequately understood, but the biological and cultural resource responses were less definitive. The studies during Period I are often ranked "poor" because the resource response was not studied (tables 81 and 8-2). Studies conducted during Period II for fish resources are ranked "poor" because monitoring data before the experiment were absent (table 8-1). The immediate response of physical resources to discharges makes it easier to link the effect of a flow treatment to the resources (Melis and others, 2006). In contrast, the response of biological resources to a change in the hydrology of a single season cannot be assessed immediately and may require several years to detect a recruitment response, as in the case of native fish (Coggins and Walters, 2009). These delayed responses by biological resources make it more difficult to link the effect of a flow treatment to the resource response.

The variability of flow within the LSSF hydrograph hampered the effectiveness of studies to assess resources responses. The hydrograph may have been classified as a steady flow discharge, but it was composed of periods with different steady discharges that varied in discharge and duration (for example, individual steady flows ranged from 4 days to 12 weeks) (fig. 8-1). During the LSSF experiment, the longest uninterrupted period of persistent habitat for young-of-year (YOY) fish was 3 months. YOY fish that entered the mainstem in mid-July (for example, humpback chub (Gila cypha) had a shorter exposure to persistent habitat. The variability in the duration and magnitude of the discharge complicated drawing conclusions about resource responses to "steady discharges." Uncertainty in resource response to the variable discharges is particularly true for fish populations that have been documented to improve under persistent habitat conditions (Travnichek and others, 1995; Freeman and others, 2001; Korman, 2009). The LSSF experimental hydrograph might not have provided persistent habitat for the target resource: YOY humpback chub in the mainstem. 
This page left intentionally blank 
Table 8.1. Responses of physical and aquatic resources of the Colorado River in Grand Canyon, Arizona, to the Low Steady Summer Flow experimental flows in 2000 , and an evaluation of the effectiveness of studies to provide information about resource responses.

\begin{tabular}{|c|c|c|c|c|c|c|c|}
\hline $\begin{array}{l}\text { Potential benefits to } \\
\text { physical resources }\end{array}$ & $\begin{array}{l}\text { Potential risks to } \\
\text { physical resources }\end{array}$ & Resource response & $\begin{array}{l}\text { Effectiveness of } \\
\text { studies in } \\
\text { measuring } \\
\text { physical-resource } \\
\text { response }\end{array}$ & $\begin{array}{l}\text { Potential benefits to } \\
\text { aquatic resources }\end{array}$ & $\begin{array}{l}\text { Potential risks to } \\
\text { biological } \\
\text { resources }\end{array}$ & Resource response & $\begin{array}{l}\text { Effectiveness of } \\
\text { studies in } \\
\text { measuring } \\
\text { biological-resource } \\
\text { response }\end{array}$ \\
\hline \multicolumn{8}{|c|}{ Period I: March to May } \\
\hline $\begin{array}{l}\text { Scour, backwaters, } \\
\text { eddies, and } \\
\text { increase in area for } \\
\text { shoreline fish } \\
\text { habitat }\end{array}$ & $\begin{array}{l}\text { No hypotheses } \\
\text { offered }\end{array}$ & $\begin{array}{l}\text { Inferred backwater } \\
\text { scoured by } \\
\text { increased sand } \\
\text { volumes in mid- } \\
\text { elevation sandbars } \\
\text { (Goeking and } \\
\text { others, unpub. } \\
\text { report, 2003; Hazel } \\
\text { and others, 2006; } \\
\text { Schmidt and } \\
\text { others, 2007). }\end{array}$ & $\begin{array}{l}\text { FAIR } \\
\text { Backwaters } \\
\text { measured only } \\
\text { following } \\
\text { September habitat } \\
\text { maintenance flow } \\
\text { during somewhat } \\
\text { enriched sediment } \\
\text { conditions } \\
\text { compared with } \\
\text { May habitat } \\
\text { maintenance flow }\end{array}$ & $\begin{array}{l}\text { Ponding as thermal } \\
\text { refuges for drifting } \\
\text { larvae and young } \\
\text { fish }\end{array}$ & $\begin{array}{l}\text { Warm, ponded } \\
\text { tributaries attract } \\
\text { nonnative fish } \\
\text { predators/ } \\
\text { competitors }\end{array}$ & Not studied & $\begin{array}{l}\text { POOR } \\
\text { Not studied }\end{array}$ \\
\hline $\begin{array}{l}\text { Mobilize and store } \\
\text { sand and sediment } \\
\text { in } \\
\text { campsites/increase } \\
\text { campsite area }\end{array}$ & $\begin{array}{l}\text { Export sediment, } \\
\text { reduce campsite } \\
\text { areas }\end{array}$ & $\begin{array}{l}\text { Sediment was } \\
\text { exported and } \\
\text { habitat } \\
\text { maintenance flow } \\
\text { executed during } \\
\text { low sediment } \\
\text { inputs (similar to } \\
1996 \text { high flow } \\
\text { experiment) } \\
\text { (Schmidt and } \\
\text { others, 2007) }\end{array}$ & $\begin{array}{l}\text { GOOD } \\
\text { Sediment response } \\
\text { is instantaneous } \\
\text { compared with } \\
\text { biological } \\
\text { resources (Melis } \\
\text { and others, 2006). } \\
\text { Sediment } \\
\text { monitoring } \\
\text { measured } \\
\text { deposition and } \\
\text { export of sediment }\end{array}$ & $\begin{array}{l}\text { Destabilize habitats } \\
\text { to disadvantage } \\
\text { nonnatives }\end{array}$ & $\begin{array}{l}\text { No hypotheses } \\
\text { offered }\end{array}$ & Not studied & $\begin{array}{l}\text { POOR } \\
\text { Not studied }\end{array}$ \\
\hline
\end{tabular}


Table 8.1. Responses of physical and aquatic resources of the Colorado River in Grand Canyon, Arizona, to the Low Steady Summer Flow experimental flows in 2000, and an evaluation of the effectiveness of studies to provide information about resource responses. - Continued

\begin{tabular}{|c|c|c|c|c|c|c|c|}
\hline $\begin{array}{l}\text { Potential benefits to } \\
\text { physical resources }\end{array}$ & $\begin{array}{l}\text { Potential risks to } \\
\text { physical resources }\end{array}$ & Resource response & $\begin{array}{l}\text { Effectiveness of } \\
\text { studies in } \\
\text { measuring } \\
\text { physical-resource } \\
\text { response }\end{array}$ & $\begin{array}{l}\text { Potential benefits to } \\
\text { aquatic resources }\end{array}$ & $\begin{array}{l}\text { Potential risks to } \\
\text { biological } \\
\text { resources }\end{array}$ & Resource response & $\begin{array}{c}\text { Effectiveness of } \\
\text { studies in } \\
\text { measuring } \\
\text { biological-resource } \\
\text { response }\end{array}$ \\
\hline $\begin{array}{l}\text { Create warm, low- } \\
\text { velocity areas at } \\
\text { tributary mouths }\end{array}$ & $\begin{array}{l}\text { No hypotheses } \\
\text { offered }\end{array}$ & $\begin{array}{l}\text { Increasing } \\
\text { mainstem } \\
\text { discharge } \\
\text { decreases low- } \\
\text { velocity, warm } \\
\text { water areas at } \\
\text { Little Colorado } \\
\text { River mouth } \\
\text { (Protiva and others, } \\
\text { 2010) }\end{array}$ & $\begin{array}{l}\text { GOOD } \\
\text { Steady discharges } \\
\text { permitted } \\
\text { measurement of } \\
\text { velocities at } \\
\text { multiple stage } \\
\text { elevations }\end{array}$ & $\begin{array}{l}\text { Redistribute } \\
\text { nutrients }\end{array}$ & $\begin{array}{l}\text { No hypotheses } \\
\text { offered }\end{array}$ & Not studied & $\begin{array}{l}\text { POOR } \\
\text { Not studied }\end{array}$ \\
\hline $\begin{array}{l}\text { No hypotheses } \\
\text { offered }\end{array}$ & $\begin{array}{l}\text { No hypotheses } \\
\text { offered }\end{array}$ & Not applicable & Not applicable & $\begin{array}{l}\text { May Habitat } \\
\text { Maintenance Flow } \\
\text { flush nonnative } \\
\text { fish from nearshore } \\
\text { habitats }\end{array}$ & $\begin{array}{l}\text { No hypotheses } \\
\text { offered }\end{array}$ & $\begin{array}{l}\text { Primary production } \\
\text { was affected } \\
\text { minimally in Lees } \\
\text { Ferry fishery } \\
\text { (Rogers and others, } \\
\text { unpub. report, } \\
\text { 2003) } \\
\text { More native fish in } \\
\text { June backwaters } \\
\text { (Trammell and } \\
\text { others, unpub. } \\
\text { report, 2002) }\end{array}$ & $\begin{array}{l}\text { FAIR } \\
\text { Studies conducted } \\
\text { in Lees Ferry } \\
\text { fishery, but no } \\
\text { studies associated } \\
\text { with downstream } \\
\text { shoreline habitats } \\
\text { POOR } \\
\text { inconclusive; data } \\
\text { not collected } \\
\text { before Habitat } \\
\text { Maintenance Flow } \\
\text { to determine if } \\
\text { abundance } \\
\text { decreased. }\end{array}$ \\
\hline
\end{tabular}


Table 8.1. Responses of physical and aquatic resources of the Colorado River in Grand Canyon, Arizona, to the Low Steady Summer Flow experimental flows in 2000, and an evaluation of the effectiveness of studies to provide information about resource responses.-Continued

\begin{tabular}{|c|c|c|c|c|c|c|c|}
\hline $\begin{array}{l}\text { Potential benefits to } \\
\text { physical resources }\end{array}$ & $\begin{array}{l}\text { Potential risks to } \\
\text { physical resources }\end{array}$ & Resource response & $\begin{array}{c}\text { Effectiveness of } \\
\text { experiment to } \\
\text { measure response }\end{array}$ & $\begin{array}{l}\text { Potential benefits to } \\
\text { aquatic resources }\end{array}$ & $\begin{array}{l}\text { Potential risks to } \\
\text { biological } \\
\text { resources }\end{array}$ & Resource response & $\begin{array}{c}\text { Effectiveness of } \\
\text { experiment to } \\
\text { measure response }\end{array}$ \\
\hline \multicolumn{8}{|c|}{ Period II: June to September } \\
\hline $\begin{array}{l}\text { Store sediment in } \\
\text { river channel }\end{array}$ & $\begin{array}{l}\text { No hypothesis } \\
\text { offered }\end{array}$ & $\begin{array}{l}\text { Few sediment } \\
\text { inputs in Period II, } \\
\text { but some sediment } \\
\text { stored with Period } \\
\text { II flows (Schmidt } \\
\text { and others, 2007). } \\
\text { habitat } \\
\text { maintenance flow } \\
\text { moved sediment to } \\
\text { mid-elevation } \\
\text { sandbars }\end{array}$ & $\begin{array}{l}\text { GOOD } \\
\text { Sediment response } \\
\text { is instantaneous } \\
\text { compared with } \\
\text { biological } \\
\text { resources (Melis } \\
\text { and others, 2006). } \\
\text { Identifies trade-off } \\
\text { between habitat } \\
\text { maintenance flow } \\
\text { and a high flow } \\
\text { experiment with } \\
\text { respect to } \\
\text { magnitude and } \\
\text { amount of } \\
\text { sediment } \\
\text { conservation. }\end{array}$ & $\begin{array}{l}\text { Increase growth } \\
\text { and survival of } \\
\text { young native fishes }\end{array}$ & $\begin{array}{l}\text { Increase growth } \\
\text { and survival of } \\
\text { nonnative fishes }\end{array}$ & $\begin{array}{l}\text { No difference with } \\
\text { previous years, } \\
\text { though comparing } \\
\text { growth with data } \\
\text { from previous } \\
\text { years may be } \\
\text { problematic }\end{array}$ & $\begin{array}{l}\text { POOR Duration of } \\
\text { steady flows was } \\
\text { interrupted by } \\
\text { habitat } \\
\text { maintenance flow. }\end{array}$ \\
\hline $\begin{array}{l}\text { Expand campable } \\
\text { beach area }\end{array}$ & $\begin{array}{l}\text { No hypothesis } \\
\text { offered }\end{array}$ & $\begin{array}{l}\text { Low stage } \\
\text { elevation expanded } \\
\text { campsites and } \\
\text { provided stable } \\
\text { campsite area } \\
\text { (Roberts and Bieri, } \\
\text { unpub. report, } \\
\text { 2001). }\end{array}$ & $\begin{array}{l}\text { GOOD } \\
\text { Sediment } \\
\text { area/volume } \\
\text { monitoring } \\
\text { identified changes } \\
\text { in mid-elevation } \\
\text { sandbars. } \\
\text { Recreation studies } \\
\text { identified benefits } \\
\text { of low steady } \\
\text { discharges on } \\
\text { camping } \\
\text { experience }\end{array}$ & $\begin{array}{l}\text { Increase } \\
\text { autotrophic algal } \\
\text { and macro } \\
\text { invertebrate } \\
\text { production }\end{array}$ & $\begin{array}{l}\text { Decrease drift of } \\
\text { food for fish }\end{array}$ & $\begin{array}{l}\text { Chironomid } \\
\text { production was } \\
\text { greater in July } \\
2000 \text { than previous } \\
\text { years; other } \\
\text { invertebrate } \\
\text { standing mass was } \\
\text { similar (Rogers } \\
\text { and others, unpub. } \\
\text { report, 2003) }\end{array}$ & $\begin{array}{l}\text { POOR } \\
\text { Data for } \\
\text { comparisons were } \\
\text { limited by } \\
\text { frequency of } \\
\text { sampling in } \\
\text { previous years and } \\
\text { discharges in } \\
\text { previous years }\end{array}$ \\
\hline
\end{tabular}


Table 8.1. Responses of physical and aquatic resources of the Colorado River in Grand Canyon, Arizona, to the Low Steady Summer Flow experimental flows in 2000, and an evaluation of the effectiveness of studies to provide information about resource responses. - Continued

\begin{tabular}{|c|c|c|c|c|c|c|c|}
\hline $\begin{array}{l}\text { Potential benefits to } \\
\text { physical resources }\end{array}$ & $\begin{array}{l}\text { Potential risks to } \\
\text { physical resources }\end{array}$ & Resource response & $\begin{array}{c}\text { Effectiveness of } \\
\text { experiment to } \\
\text { measure response }\end{array}$ & $\begin{array}{l}\text { Potential benefits to } \\
\text { aquatic resources }\end{array}$ & $\begin{array}{l}\text { Potential risks to } \\
\text { biological } \\
\text { resources }\end{array}$ & Resource response & $\begin{array}{c}\text { Effectiveness of } \\
\text { experiment to } \\
\text { measure response }\end{array}$ \\
\hline $\begin{array}{l}\text { September habitat } \\
\text { maintenance flow } \\
\text { resuspend and } \\
\text { store sand from } \\
\text { summer tributary } \\
\text { inputs }\end{array}$ & $\begin{array}{l}\text { September habitat } \\
\text { maintenance flow } \\
\text { export sand and } \\
\text { sediment instead of } \\
\text { storing it }\end{array}$ & $\begin{array}{l}\text { Sediment stored as } \\
\text { well as exported } \\
\text { (Hazel and others, } \\
\text { 2006; Schmidt and } \\
\text { others, 2007). }\end{array}$ & $\begin{array}{l}\text { GOOD } \\
\text { Sediment } \\
\text { area/volume } \\
\text { monitoring } \\
\text { identified changes } \\
\text { in mid-elevation } \\
\text { sandbars. Trade-off } \\
\text { between discharge } \\
\text { and sediment } \\
\text { storage. }\end{array}$ & $\begin{array}{l}\text { Possible mainstem } \\
\text { hatching success }\end{array}$ & $\begin{array}{l}\text { Mainstem } \\
\text { reproduction by } \\
\text { nonnative fishes }\end{array}$ & $\begin{array}{l}\text { Some indication of } \\
\text { protracted } \\
\text { spawning though } \\
\text { source of fish less } \\
\text { than } 30 \text { millimeters } \\
\text { long unknown. } \\
\text { Mainstem adult } \\
\text { rainbow trout } \\
\text { numbers were } \\
\text { greatest in } 2000 \\
\text { and } 2001 \\
\text { (Makinster and } \\
\text { others, 2010). }\end{array}$ & $\begin{array}{l}\text { POOR } \\
\text { Methods to study } \\
\text { larval origin and } \\
\text { monitoring } \\
\text { abundance are not } \\
\text { well developed. } \\
\text { POOR } \\
\text { Population } \\
\text { estimates or catch } \\
\text { per unit data were } \\
\text { unavailable for } \\
\text { rainbow and brown } \\
\text { trout before Low } \\
\text { Steady Summer } \\
\text { Flows experiment } \\
\text { to determine } \\
\text { downstream } \\
\text { effects. }\end{array}$ \\
\hline $\begin{array}{l}\text { Create stable } \\
\text { shorelines for fish } \\
\text { habitat }\end{array}$ & $\begin{array}{l}\text { No hypothesis } \\
\text { offered }\end{array}$ & No data & $\begin{array}{l}\text { POOR } \\
\text { Not studied }\end{array}$ & $\begin{array}{l}\text { September habitat } \\
\text { maintenance flow } \\
\text { may flush } \\
\text { nonnative fishes } \\
\text { from nearshore } \\
\text { habitats }\end{array}$ & $\begin{array}{l}\text { Minimizing } \\
\text { thermal plume at } \\
\text { springs located at } \\
\text { river mile } 30 \text { may } \\
\text { reduce survival of } \\
\text { young humpback } \\
\text { chub }\end{array}$ & $\begin{array}{l}\text { Habitat } \\
\text { Maintenance Flow } \\
\text { effect on } \\
\text { nonnatives } \\
\text { inconclusive }\end{array}$ & $\begin{array}{l}\text { POOR } \\
\text { Abundances of } \\
\text { nonnative fish } \\
\text { were the same or } \\
\text { less than native } \\
\text { fishes (Trammell } \\
\text { and others, unpub. } \\
\text { report, 2002) }\end{array}$ \\
\hline
\end{tabular}


Table 8.1. Responses of physical and aquatic resources of the Colorado River in Grand Canyon, Arizona, to the Low Steady Summer Flow experimental flows in 2000, and an evaluation of the effectiveness of studies to provide information about resource responses. - Continued

\begin{tabular}{|c|c|c|c|c|c|c|c|}
\hline $\begin{array}{l}\text { Potential benefits to } \\
\text { physical resources }\end{array}$ & $\begin{array}{l}\text { Potential risks to } \\
\text { physical resources }\end{array}$ & Resource response & $\begin{array}{l}\text { Effectiveness of } \\
\text { experiment to } \\
\text { measure response }\end{array}$ & $\begin{array}{l}\text { Potential benefits to } \\
\text { aquatic resources }\end{array}$ & $\begin{array}{l}\text { Potential risks to } \\
\text { biological } \\
\text { resources }\end{array}$ & Resource response & $\begin{array}{l}\text { Effectiveness of } \\
\text { experiment to } \\
\text { measure response }\end{array}$ \\
\hline $\begin{array}{l}\text { No other } \\
\text { hypotheses }\end{array}$ & $\begin{array}{l}\text { No other } \\
\text { hypotheses }\end{array}$ & Not applicable & Not applicable & $\begin{array}{l}\text { No other } \\
\text { hypotheses }\end{array}$ & $\begin{array}{l}\text { Increased water } \\
\text { clarity leading to } \\
\text { increased predation } \\
\text { of native fish by } \\
\text { sight predators }\end{array}$ & & $\begin{array}{l}\text { POOR Stomach } \\
\text { analysis of } \\
\text { predators was } \\
\text { limited, small- } \\
\text { sized fishes leave } \\
\text { few parts for } \\
\text { identification. } \\
\text { Subsequent data } \\
\text { collection and } \\
\text { correlation with } \\
\text { population } \\
\text { estimates of } \\
\text { rainbow and brown } \\
\text { trout } 2000 \text { (Speas } \\
\text { and others, unpub. } \\
\text { report, } 2004 \text {; Yard } \\
\text { and others, 2011) } \\
\text { could suggest a } \\
\text { high probability of } \\
\text { predation occurred } \\
\text { in } 2000 \text { and } \\
\text { contributed to a } \\
\text { lack of response by } \\
\text { native fish. }\end{array}$ \\
\hline $\begin{array}{l}\text { No other } \\
\text { hypotheses }\end{array}$ & $\begin{array}{l}\text { No other } \\
\text { hypotheses }\end{array}$ & Not applicable & Not applicable & $\begin{array}{l}\text { No other } \\
\text { hypotheses }\end{array}$ & $\begin{array}{l}\text { Increased } \\
\text { infestation of } \\
\text { parasites and } \\
\text { diseases }\end{array}$ & not studied & $\begin{array}{l}\text { POOR } \\
\text { No data were } \\
\text { collected }\end{array}$ \\
\hline
\end{tabular}


Table 8.1. Responses of physical and aquatic resources of the Colorado River in Grand Canyon, Arizona, to the Low Steady Summer Flow experimental flows in 2000, and an evaluation of the effectiveness of studies to provide information about resource responses. - Continued

\begin{tabular}{|c|c|c|c|c|c|c|c|}
\hline $\begin{array}{l}\text { Potential benefits to } \\
\text { physical resources }\end{array}$ & $\begin{array}{l}\text { Potential risks to } \\
\text { physical resources }\end{array}$ & Resource response & $\begin{array}{c}\text { Effectiveness of } \\
\text { experiment to } \\
\text { measure response }\end{array}$ & $\begin{array}{l}\text { Potential benefits to } \\
\text { aquatic resources }\end{array}$ & $\begin{array}{l}\text { Potential risks to } \\
\text { biological } \\
\text { resources }\end{array}$ & Resource response & $\begin{array}{c}\text { Effectiveness of } \\
\text { experiment to } \\
\text { measure response }\end{array}$ \\
\hline \multicolumn{8}{|c|}{ Period III: October to February } \\
\hline $\begin{array}{l}\text { Retain sediment } \\
\text { with low-volume } \\
\text { discharge }\end{array}$ & No data & $\begin{array}{l}\text { Not studied and } \\
\text { returned to } \\
\text { Modified Low } \\
\text { Fluctuating Flow } \\
\text { operations }\end{array}$ & $\begin{array}{l}\text { POOR } \\
\text { Not implemented }\end{array}$ & $\begin{array}{l}\text { Increased survival } \\
\text { of young native } \\
\text { fishes }\end{array}$ & $\begin{array}{l}\text { Possible } \\
\text { overwinter survival } \\
\text { and expansion of } \\
\text { nonnative fishes }\end{array}$ & $\begin{array}{l}\text { Not studied and } \\
\text { returned to } \\
\text { Modified Low } \\
\text { Fluctuating Flow } \\
\text { operations }\end{array}$ & $\begin{array}{l}\text { POOR } \\
\text { Not implemented }\end{array}$ \\
\hline $\begin{array}{l}\text { No other } \\
\text { hypotheses }\end{array}$ & $\begin{array}{l}\text { No other } \\
\text { hypotheses }\end{array}$ & Not applicable & Not applicable & $\begin{array}{l}\text { Maintain stable } \\
\text { winter conditions } \\
\text { to minimize energy } \\
\text { expenditure }\end{array}$ & $\begin{array}{l}\text { Possible greater } \\
\text { spawning success } \\
\text { of downstream } \\
\text { populations of } \\
\text { trout }\end{array}$ & $\begin{array}{l}\text { Not studied and } \\
\text { returned to } \\
\text { Modified Low } \\
\text { Fluctuating Flow } \\
\text { operations }\end{array}$ & $\begin{array}{l}\text { POOR } \\
\text { Not implemented } \\
\text { Returned to } \\
\text { Modified Low } \\
\text { Fluctuating Flow } \\
\text { operations }\end{array}$ \\
\hline $\begin{array}{l}\text { No other } \\
\text { hypotheses }\end{array}$ & $\begin{array}{l}\text { No other } \\
\text { hypotheses }\end{array}$ & Not applicable & Not applicable & $\begin{array}{l}\text { Maintain } \\
\text { overwinter } \\
\text { autotrophic } \\
\text { production in } \\
\text { mainstem, } \\
\text { shorelines, and } \\
\text { backwaters }\end{array}$ & $\begin{array}{l}\text { Decreased drift of } \\
\text { food for fish }\end{array}$ & $\begin{array}{l}\text { Not studied and } \\
\text { returned to } \\
\text { Modified Low } \\
\text { Fluctuating Flow } \\
\text { operations }\end{array}$ & $\begin{array}{l}\text { POOR } \\
\text { Not implemented } \\
\text { Returned to } \\
\text { Modified Low } \\
\text { Fluctuating Flow } \\
\text { operations }\end{array}$ \\
\hline $\begin{array}{l}\text { No other } \\
\text { hypotheses }\end{array}$ & $\begin{array}{l}\text { No other } \\
\text { hypotheses }\end{array}$ & Not applicable & Not applicable & $\begin{array}{l}\text { No other } \\
\text { hypotheses }\end{array}$ & $\begin{array}{l}\text { Increased predation } \\
\text { by sight feeders }\end{array}$ & $\begin{array}{l}\text { Not studied and } \\
\text { returned to } \\
\text { Modified Low } \\
\text { Fluctuating Flow } \\
\text { operations }\end{array}$ & $\begin{array}{l}\text { POOR } \\
\text { Not implemented } \\
\text { Returned to } \\
\text { Modified Low } \\
\text { Fluctuating Flow } \\
\text { operations }\end{array}$ \\
\hline
\end{tabular}


Table 8-2. Responses of other than physical and aquatic resources of the Colorado River in Grand Canyon, Arizona, to the Low Steady Summer Flow experimental flows in 2000 and an evaluation of the effectiveness of studies to provide information about resource responses.

\begin{tabular}{|c|c|c|c|}
\hline Resource & $\begin{array}{l}\text { Anticipated resource } \\
\text { response }\end{array}$ & Observed resource response & $\begin{array}{l}\text { Effectiveness of studies in } \\
\text { measuring resource response }\end{array}$ \\
\hline \multicolumn{4}{|c|}{ Period I: March to May } \\
\hline Riparian Vegetation & $\begin{array}{l}\text { Reworking of } \\
\text { shoreline habitats }\end{array}$ & $\begin{array}{l}\text { Scour of vegetation until } \\
\text { sustained high-flow stage } \\
\text { elevation }\end{array}$ & $\begin{array}{l}\text { POOR } \\
\text { No data collection before } \\
\text { sustained flows. Observation } \\
\text { began at beginning of Period } \\
\text { II. Insufficient time available } \\
\text { to collect Period I data }\end{array}$ \\
\hline $\begin{array}{l}\text { Recreation } \\
\text { Safety }\end{array}$ & $\begin{array}{l}\text { Accidents associated } \\
\text { with May habitat } \\
\text { maintenance flow }\end{array}$ & Unknown with respect to safety & $\begin{array}{l}\text { POOR } \\
\text { Not studied. Insufficient } \\
\text { time available to collect } \\
\text { Period I data }\end{array}$ \\
\hline $\begin{array}{l}\text { Recreation } \\
\text { Perceptions/Satisfaction } \\
\text { (Angling/Whitewater } \\
\text { Rafting) }\end{array}$ & $\begin{array}{l}\text { No response } \\
\text { anticipated }\end{array}$ & $\begin{array}{l}\text { Unknown with respect to rafting } \\
\text { experience. } \\
\text { Fishing trips did not occur } \\
\text { during habitat maintenance flow }\end{array}$ & $\begin{array}{l}\text { POOR } \\
\text { Not studied. Insufficient } \\
\text { time available to collect } \\
\text { Period I data }\end{array}$ \\
\hline $\begin{array}{l}\text { Economics } \\
\text { Angling/Whitewater } \\
\text { Rafting }\end{array}$ & $\begin{array}{l}\text { No response } \\
\text { anticipated }\end{array}$ & $\begin{array}{l}\text { Angling-Access limited during } \\
\text { habitat maintenance flow and } \\
\text { revenues reduced. } \\
\text { Whitewater Rafting-not } \\
\text { studied }\end{array}$ & $\begin{array}{l}\text { FAIR } \\
\text { Angling; contacted fishing } \\
\text { services but did not evaluate } \\
\text { in context of fish population } \\
\text { condition. } \\
\text { POOR } \\
\text { Whitewater Rafting; not } \\
\text { studied. }\end{array}$ \\
\hline $\begin{array}{l}\text { Economics } \\
\text { Power Revenues }\end{array}$ & $\begin{array}{l}\text { Shift in extra power } \\
\text { generation to lower } \\
\text { power demand } \\
\text { months-no pre- } \\
\text { analysis available }\end{array}$ & $\begin{array}{l}\text { Revenues increased with May } \\
\text { habitat maintenance flow, but } \\
\text { extra water released in March } \\
\text { resulted in financial loss because } \\
\text { of subsequent minimum delivery } \\
\text { years associated with ongoing } \\
\text { drought. }\end{array}$ & $\begin{array}{l}\text { FAIR } \\
\text { Only post-hoc analysis } \\
\text { available and multiple } \\
\text { factors (climate, market } \\
\text { manipulation) affected } \\
\text { financial outcome }\end{array}$ \\
\hline \multicolumn{4}{|c|}{ Period II: June to September } \\
\hline Riparian Vegetation & No effects anticipated & $\begin{array}{l}\text { Extensive tamarisk seedling } \\
\text { establishment. September HMF } \\
\text { reduced stem densities }\end{array}$ & $\begin{array}{l}\text { GOOD } \\
\text { Steady flows timed in June } \\
\text { before other plant flowering } \\
\text { insured a positive response } \\
\text { by tamarisk }\end{array}$ \\
\hline
\end{tabular}


Table 8-2. Responses of other than physical and aquatic resources of the Colorado River in Grand Canyon, Arizona, to the Low Steady Summer Flow experimental flows in 2000 and an evaluation of the effectiveness of studies to provide information about resource responses.-Continued

\begin{tabular}{llll}
\hline Resource & $\begin{array}{c}\text { Anticipated resource } \\
\text { response }\end{array}$ & \multicolumn{1}{c}{ Observed resource response } & $\begin{array}{l}\text { Effectiveness of studies in } \\
\text { measuring resource response }\end{array}$ \\
\hline Recreation & No effects anticipated & $\begin{array}{l}\text { Some accidents early in season } \\
\text { because of inexperience with } \\
\text { Safety }\end{array}$ & FAIR \\
& & Unpublished report from \\
& & $\begin{array}{l}\text { National Park Service } \\
\text { referencing other } \\
\text { unpublished reports }\end{array}$
\end{tabular}

Recreation

Perceptions/Satisfaction

(Angling/Whitewater

Rafting)
No effects anticipated

Angling; Steady discharge provided more access to anglers without boats. Drift was at lower concentrations and may have affected angler satisfaction Whitewater rafting; Perceptions affected by multiple inputs with flows a minor component. Hiking options changed. Camps available at low discharge used, which reduced crowding issues.

No effects anticipated

Whitewater

Rafting/Angling

Economics

Power Revenues
Reduction in power generation Financial costs with equipment
Whitewater rafting; replacement and trip refunds Angling; Loss of revenue during September habitat maintenance flow

Reduced power generation and spot market costs to meet consumer needs were inflated because of California energy crisis and price manipulation in summer 2000 -an unanticipated cost.

\section{POOR}

Angling; minor studies evaluated angling satisfaction. Difficult to assess because of continued decline of fishery that began before Low steady summer flow experiment

\section{FAIR}

Whitewater rafting; Multiple studies assess single aspects of low discharge and whitewater rafting. Did not provide a multidimensional evaluation of the effect the LSSF hydrograph had on the rafting experience

\section{FAIR}

Analysis of longer-term economic effect would be useful - How does LSSF experiment affect financial costs in subsequent years?

\section{FAIR}

Post-hoc analysis was good. Sufficient time for a preexperiment analysis to estimate costs and possibly refine/refocus experimental efforts, which would have been helpful.

Implementing flows intended to mimic natural conditions is challenging in river systems that are constrained by water-delivery requirements and the needs of multiple resources that can be in conflict. The magnitude and duration of discharges required for a desired response by one resource may be in direct conflict with the desired responses by other resources. Yet approaching experimentation in a manner that mitigates for effects to resources can produce a weak experimental design and a poor or undetectable response by the target resource (Webb and others, 2010). The resulting information can be inconclusive for some resources (tables 8-1 and $8-2$ ), but costly to others, and can promote the perception that ecological experiments are costly, 
yield little benefit to the target resources, and thus fail to demonstrate the benefits of an experimental flow. Follow-up cost/benefit evaluations might suggest that the experiment does not merit repeating. Success of an ecosystem-scale experiment is limited further if time for planning an experiment and associated monitoring is reduced, as occurred with the LSSF experiment in 2000 .

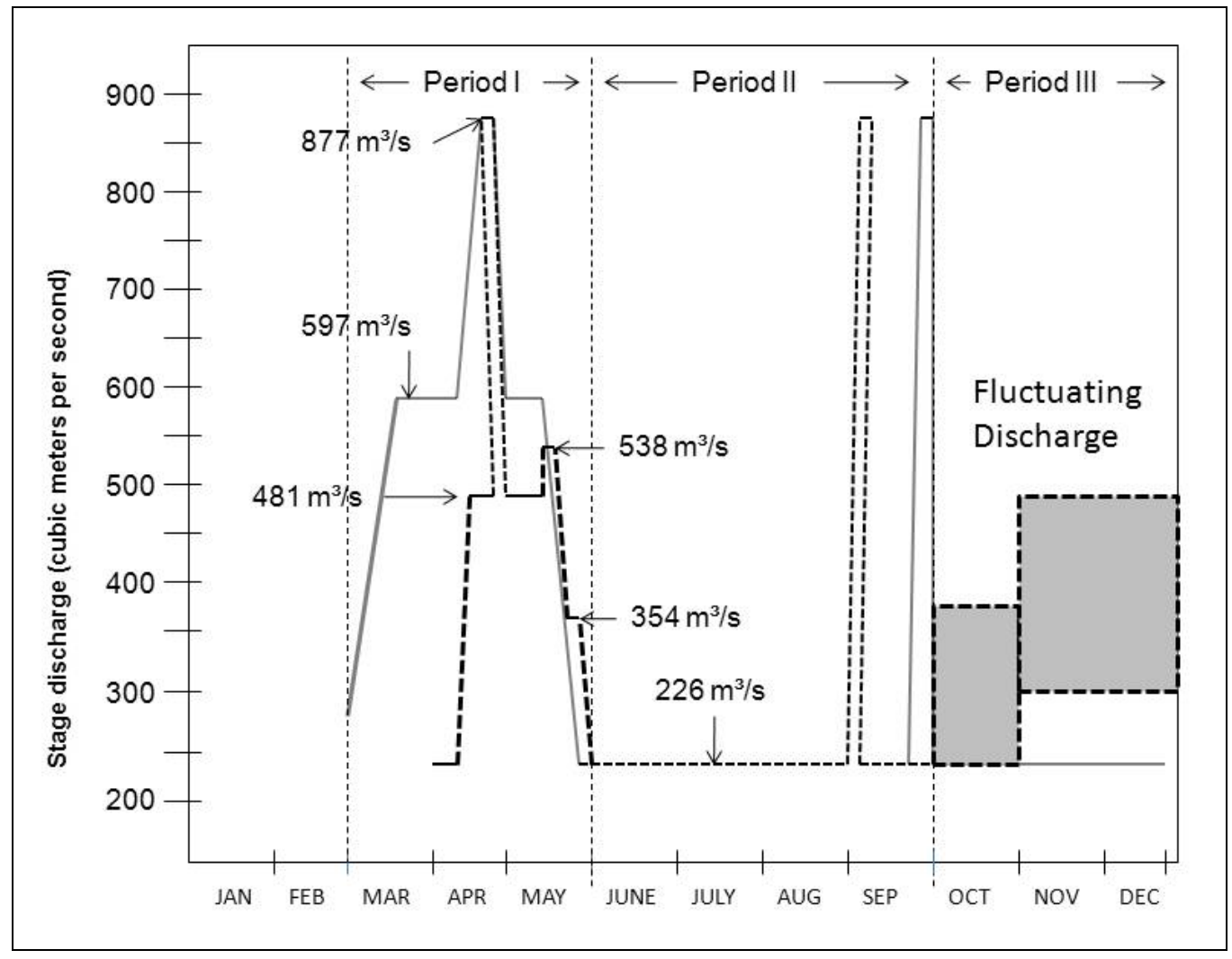

Figure 8-1. Actual release pattern of the experimental flow period from March to October 2000 (dotted line) compared with the proposed experimental hydrograph (solid line) from Valdez and others (unpub. report, 2000).

The LSSF experimental hydrograph proposed by Valdez and others (unpub. report, 2000), and subsequently modified and implemented in 2000, is an example of an experiment that was modified to ameliorate potential negative resource effects and resulted in compromising the effectiveness of the experiment to test response of the target resource (humpback chub). The spring discharges, limited by water allocations, were only 25 percent greater (U.S. Geological Survey, 2010) than the average MLFF discharges in the 1990s and 78-percent smaller than the average predam spring discharge of approximately $2,407 \mathrm{~m}^{3} / \mathrm{s}$ (Topping and others, 2003). The changes in discharge associated with the experimental hydrograph were likely too small compared to standard operations to observe a response that differed from previous years. Though overall discharges in Period I were steady, they varied in magnitude between April and May and failed to provide a consistent, elevated discharge that was greater than average discharges observed in the 1990s. Further, the sustained high flows occurred in a year of few sediment 
inputs in the winter, resulting in sediment export from the Grand Canyon reach (Schmidt and others, 2007), a negative resource response.

For the native fishes that persist in the Colorado River downstream from Glen Canyon Dam, the YOY life stage is affected by the Colorado River mainstem hydrology, whereas earlier life stages (for example, larvae and eggs) are affected by tributary hydrology (Gorman and Stone, 1999; Robinson and others, 1998). The bulk of YOY fish enter the mainstem from tributaries in the summer months, with humpback chub YOY entering the mainstem primarily in association with monsoons that begin in July (Valdez and Ryel, unpub. report, 1995; Valdez and Carothers, unpub. report, 1998; Robinson and others, 1998). It is more likely that dam operations can be used to affect YOY and later life stages of native fish because of their mainstem habits, as opposed to larval fish that are found more often in tributaries.

Although Period I might be characterized by a failure to reach discharge magnitude sufficiently different from average discharges, Period II might be characterized by a failure to reach a duration of sufficient length to measure a response. The duration of the low steady flow part of the experiment was interrupted by a September HMF and was suspended at the end of September. The September HMF was implemented to reduce the negative effects of exotic fishes in the system. The suspension of steady discharges in October was to mitigate for financial costs to power resources incurred during the summer months (Palmer and others, unpub. report, 2004).

Because humpback chub first enter the Colorado River in July from tributaries, it is difficult to expect that measurements of growth or abundance would have been noticeably different from previous years. In 2000, most YOY humpback chub likely entered the mainstem in July and August, just as in other years (Valdez and Ryel, unpub. report, 1995; Valdez and Carothers, unpub. report, 1998; Robinson and others, 1998). The humpback chub length data collected near the Little Colorado River (LCR) lends support to this observation (Trammell and others, unpub. report, 2002). These fish would have been under a steady-flow discharge pattern for a month or 6 weeks before an HMF. The HMF disrupted the habitat stability intent of the steady flows. A month following the September HMF, the fish were exposed to MLFF operations that were similar to those implemented since 1990. Further, the greater predation threat to native fish is adult salmonids (brown (Salmo trutta) and rainbow trout (Oncorhynchus mykiss)) that are affected minimally by discharges that reach $1,412 \mathrm{~m}^{3} / \mathrm{s}$ (Hoffnagle and others, 1999; McKinney and others, 1999; Hilwig and Makinster, 2010). The timing and duration of steady flows for the target species may have been too early (Korman and others, 2004) and too brief a period to be effective. The implementation of the late season HMF, which was incorporated to disadvantage nonnative species (Valdez and others, unpub report, 2000), when young fish are using the mainstem shoreline, disrupted stable habitats and closely mimicked noaction discharges that brought about the changes to dam operations in the 1990s (U.S. Department of the Interior, 1995). The return to fluctuating flows to help alleviate the negative financial effects of Period II (Palmer and others, unpub. report, 2004; Harpman and Douglas, 2005) shortened the duration of stable habitats for YOY fishes. Both measures diluted the ability to observe a response by native fish to stabilized habitats.

Planning for effective high-magnitude discharges for ecological experiments is challenging in a regulated system (Webb and others, 1999; Patten and Stevens, 2001; Webb and others, 2010). The presence of a dam restricts flow magnitude, and a reservoir system designed for water storage further restricts annual discharges. However, a change in discharge magnitude is the most common element associated with regulation, and fish appear to be most sensitive to this variable (Poff and others, 2009). The life-history stages of fish are integrally tied to seasonal 
discharges and associated thermal conditions and, as a result, are sensitive to changes in the timing rates of discharge (Humphries and others, 1999; Marchetti and Moyle, 2001). Identifying a single life stage that is associated with a particular discharge and that limits recruitment in an endangered fish species is difficult. Colorado River native fishes are long-lived and the year-toyear recruitment variability may be affected by conditions in tributaries and the mainstem. Identifying the linkage between discharge and recruitment limitations after a single-season flow treatment is unrealistic. Determining the effectiveness of a single-year experimental hydrograph becomes particularly difficult when the variables intended to be changed (optimum water temperatures and long-duration steady discharges) are not achievable at key locations within the river system at the time of the experiment.

\section{Lessons Learned and Considerations for Experimental Planning}

The results associated with the LSSF experiment were inconclusive for the target resource: humpback chub. In some cases, the responses of ancillary resources were more definitive (for example, sediment, recreational whitewater rafting), but the responses of these resources are more immediate and potentially more easily quantifiable than early life stages of fish. For informative flow experiments, the duration and magnitude of the discharge and the life history or response time of a targeted resource need to be considered. Furthermore, altering only discharge rates may be insufficient for some resources. The LSSF hydrograph was insufficient in duration to elicit a measurable response by YOY fishes. Multiple years of a single treatment may be required to observe a response by native fish because they are long-lived, and distinguishing between the effects of a single year's hydrologic treatment from year-to-year variability in YOY numbers and growth is difficult. Mainstem water temperatures did not warm sufficiently during Period II of the LSSF experiment to meet optimal growth requirements of humpback chub, except in the western parts of Grand Canyon. The greatest numbers of humpback chub occur near the LCR (Douglas and Marsh, 1996; Coggins and Walters, 2009). Targeting low discharges when release temperatures from Glen Canyon Dam are greater than average may be more informative than simply reducing discharges when water temperatures at the dam are average. Native fish monitoring data associated with multiple years of warmwater discharges for Glen Canyon Dam between 2003 and 2006 suggest that some native fish benefitted from the warmer water even during fluctuating discharges. However, predator control measures were implemented at the same time, which confounds knowing if increased temperatures or decreased predator loads affected the recruitment response by humpback chub and other native fishes (Coggins, 2008). Given the constraints in water delivery, experimental hydrographs that focus on life stages that are affected directly by mainstem operations may be more informative experiments (for example, lower mid-summer and fall flows and YOY habitat).

Flexibility in implementing experiments would benefit learning about resource response in this system. Basin hydrology and reservoir elevations greatly affect experimental capacity in this system. Basin hydrology affects sediment inputs, inflows to Lake Powell, and water delivery requirements between the upper and lower Colorado River Basin. Taking advantage of unexpected inputs to the system either by way of large sediment inputs or increased release temperatures as a result of reduced inflows and associated reservoir elevations can be used to further understanding of how best to manage the downstream resources. When reservoir elevations allow discharge temperatures to exceed $13^{\circ} \mathrm{C}$, it may be informative to implement steady discharges to see how YOY fish at the LCR respond to warmer temperatures and steady 
discharges. The results can be compared with data collected during 2003-6 during fluctuating discharges and possibly different predator loads, provided sufficient long-term monitoring is in place.

Flexibility in dam releases requires adequate long-term monitoring be in place to measure responses. Additionally, stakeholders need to reconcile a need for immediate measures of response that may be satisfying in the short term but meaningless in the longer-term, particularly for long-lived species. A lack of response observed for 1 year may not mean the treatment was ineffective. Multiple years of a treatment may be necessary for a response to be measurable. For example, 4 years of predator control between 2003 and 2006 are correlated with an increase in the number of native fish, including humpback chub (Coggins and Walters, 2009). However, the increased native fish numbers were not an observable response for a year or two following the initiation of the treatment. Further, a combination of warmer temperatures and predator control likely affected native fish numbers (Coggins, 2008). Because native fish are long-lived, flow treatments or other non-flow experimental treatments likely will require multiple-year efforts to be informative. Other resources may require shorter-duration treatment (for example, sediment), but the duration and seasonal timing still need to be considered (for example, experiments that limit tamarisk (Tamarix spp.) expansion or recruitment of rainbow trout in the Lees Ferry fishery).

Experimental flexibility requires the implementation of robust long-term monitoring that can measure a response for the long term and supplement data collection that is more intensive during the experiment. The variables measured by monitoring are unlikely to be at a detail that explains incremental change, but monitoring should be sufficient to measure year-to-year change in the resource. A direct mechanistic response to a proposed treatment may first be measured in a laboratory setting and then sampled in the field. Having sufficient background data to compare against a treatment timeframe is essential to determining an effect. Previous data associated with fish in the Colorado River ecosystem were collected in relation to the Operation of Glen Canyon Dam Final Environmental Impact Statement and not associated with status and trend monitoring. The 2000 LSSF experiment resulted in the initiation of a more consistent, quantitatively robust approach to fish sampling in the mainstem and LCR that has been incorporated in long-term monitoring. Monitoring needs to include resources beyond the immediately affected resources. Evaluating these other resources is an important element in evaluating ecosystem responses to experimental flow treatments.

It is important for results from experiments to be published in reports and peer-reviewed journal articles, as well as summarized for stakeholder use. Cooperator reports are the first step in the process of incorporating knowledge but not the final step. Having citable literature that can be incorporated into larger synthetic efforts is critical to building a solid basis for documenting results and furthering experimental planning and decisionmaking by resource managers. Experimental planning would be most effective if it includes funding and time for these reporting efforts. The 10-year delay in the summary of results of the LSSF experiment has allowed incorporation of long-term biological responses (for example, Coggins and Walters, 2009), but has limited the Glen Canyon Dam Adaptive Management Program with respect to the identification of the efficacy of long-duration experiments. The LSSF experiment was the first seasonally based experiment using Glen Canyon Dam releases that focused on biological resources, primarily native fish. Although some results associated with fish growth were inconclusive, the experimental hydrograph did support learning about other fish-related resources like shoreline habitat (Korman and others, 2004; Protiva and others, 2010). The 
response by other resources to high and low discharges, particularly sediment (Schmidt and others, 2007), riparian vegetation (Porter, 2002), and recreational and economic responses (Roberts and Bieri, unpub. report, 2001; Hjerpe and Kim, unpub. report, 2003; Palmer and others, unpub. report, 2004) are better known. Incorporating this knowledge into the next event that involves measuring a response to long-lived species is critical if the effort is to be useful for resource managers.

\section{References}

Coggins, L.G., Jr., 2008, Active adaptive management for native fish conservation in the Grand Canyon-implementation and evaluation: Gainesville, University of Florida, Ph.D. dissertation, $174 \mathrm{p}$.

Coggins, L.G., Jr., and Walters, C.J., 2009, Abundance trends and status of the Little Colorado River population of humpback chub — an update considering data from 1989-2008: U.S. Geological Survey Open-File Report 2009-1075, 18 p., accessed on August 19, 2011, at http://pubs.usgs.gov/of/2009/1075/.

Douglas, M.E., and Marsh, P.C., 1996, Population estimates/population movements of Gila cypha, an endangered cyprinid fish in the Grand Canyon region of Arizona: Copeia, v. 1996, no. 1, p. 15-28, accessed on February 10, 2010, at http://www.jstor.org/stable/pdfplus/1446938.pdf.

Freeman, M.C., Bowen Z.H., Bovee, K.D., Irwin, E.R., 2001, Flow and habitat effects on juvenile fish abundance in natural and altered flow regimes: Ecological Applications, v. 11, no. 1, p. 179-190, accessed on August 23, 2011, at http://www.jstor.org/stable/3061065.

Goeking, S.A., Schmidt, J.C., and Webb, M.K., 2003, Spatial and temporal trends in the size and number of backwaters between 1935 and 2000, Marble and Grand Canyons, Arizona-final report: U.S. Geological Survey, Grand Canyon Monitoring and Research Center and Utah State University, Department of Aquatic, Watershed and Earth Resources, cooperative agreement no. 01WRAG0059, 26 p. [Available upon request by contacting the Center Director, U.S. Geological Survey, Southwest Biological Science Center, 2255 N. Gemini Drive, Flagstaff, Ariz. 86001.]

Gorman, O.T., and Stone, D.M., 1999, Ecology of spawning humpback chub, Gila cypha, in the Little Colorado River near Grand Canyon, Arizona: Environmental Biology of Fishes, v. 55, no. 1-2, p. 115-133, accessed on February 12, 2010, at http://www.springerlink.com/content/vq675171n84786p7/.

Harpman, D.A., and Douglas, A.J., 2005, Status and trends of hydropower at Glen Canyon Dam, in Gloss, S.P., Lovich, J.E., and Melis, T.S., eds., The state of the Colorado River ecosystem in Grand Canyon: U.S. Geological Survey Circular 1282, 165-176 p., accessed on May 10, 2010, at http://pubs.usgs.gov/circ/1282/.

Hazel, J.E., Jr., Topping, D.J., Schmidt, J.C., and Kaplinski, M., 2006, Influence of a dam on fine-sediment storage in a canyon river: Journal of Geophysical Research, v. 111, no. F01025, p. 1-16, accessed on December 28, 2009, at http://www.agu.org/journals/jf/jf0601/2004JF000193/2004JF000193.pdf.

Hilwig, K.D., and Makinster, A.S., 2010, Evaluating effects of a high-flow event on rainbow trout movement in Glen and Marble Canyons, Arizona, by using acoustic telemetry and relative abundance measures, in Melis, T.S., Hamill, J.F., Bennett, G.E., Coggins, L.G., Jr., Grams, P.E., Kennedy, T.A., Kubly, D.M., and Ralston, B.E., eds., Proceedings of the Colorado River Basin Science and Resource Management Symposium, November 18-20, 
2008, Scottsdale, Arizona: U.S. Geological Survey Scientific Investigations Report 2010-5135, 219-225 p., accessed on July 15, 2010, at http://pubs.usgs.gov/sir/2010/5135/.

Hjerpe, E., and Kim, Y.-S., 2003, Economic impacts of summer steady flows on recreation: Flagstaff, Northern Arizona University, School of Forestry, 21 p. [Available upon request by contacting the Center Director, U.S. Geological Survey, Southwest Biological Science Center, 2255 N. Gemini Drive, Flagstaff, Ariz. 86001.]

Hoffnagle, T.L., Valdez, R.A., and Speas, D.W., 1999, Fish abundance, distribution, and habitat use, in Webb, R.H., Schmidt, J.C., Marzolf, G.R., and Valdez, R.A., eds., The controlled flood in Grand Canyon, v. 110: Washington, D.C., American Geophysical Union, Geophysical Monograph Series, p. 273-287.

Humphries, P., King, A.J., and Koehn, J.D., 1999, Fish, flows and flood plains-links between freshwater fishes and their environment in the Murray-Darling River system, Australia: Environmental Biology of Fishes, v. 56, no. 1-2, p. 129-151, accessed on August 19, 2011, at http://www.springerlink.com/content/v14876jp5181g7q0/.

Korman, J., 2009, Early life history dynamics of rainbow trout in a large regulated river: Vancouver, University of British Columbia, Ph.D. dissertation, $233 \mathrm{p}$.

Korman, J., Wiele, S.M., and Torizzo, M., 2004, Modelling effects of discharge on habitat quality and dispersal of juvenile humpback chub (Gila cypha) in the Colorado River, Grand Canyon: River Research and Applications, v. 20, no. 4, p. 379-400, accessed on February 22, 2010, at http://www3.interscience.wiley.com/cgi-bin/fulltext/107614374/PDFSTART.

Korman, J., Yard, M., Walters, C.J., and Coggins, L.G., 2009, Effects of fish size, habitat, flow, and density on capture probabilities of age- 0 rainbow trout estimated from electrofishing at discrete sites in a large river: Transactions of the American Fisheries Society, v. 138, no. 1, p. 58-75, accessed on June 1, 2011, at http://www.tandfonline.com/doi/abs/10.1577/T08-025.1.

Makinster, A.S., Persons, W.R., Avery, L.A., and Bunch, A.J., 2010, Colorado River fish monitoring in Grand Canyon, Arizona - 2000 to 2009 summary: U.S. Geological Survey Open-File Report 2010-1246, 26 p., accessed on November 5, 2010, at http://pubs.usgs.gov/of/2010/1246/.

Marchetti, M.P. and Moyle, P.B., 2001, Effects of flow regime on fish assemblages in a regulated California stream. Ecological Applications, v. 11, no. 2, p. 530-539, accessed on August 23, 2011, at http://www.jstor.org/stable/3060907.

McKinney, T., Rogers, R.S., and Persons, W.R., 1999, Effects of flow reductions on aquatic biota of the Colorado River below Glen Canyon Dam, Arizona: North American Journal of Fisheries Management, v. 19, no. 4, p. 984-991, accessed on August 19, 2011 at http://dx.doi.org/10.1577/1548-8675(1999)019<0984:EOFROA>2.0.CO;2.

Melis, T.S., Martell, S.J.D., Coggins, L.G., Pine, W.E., III, and Andersen, M.E., 2006, Adaptive management of the Colorado River ecosystem below Glen Canyon Dam, Arizona - using science and modeling to resolve uncertainty in river management, in Specialty Summer Conference on Adaptive Management of Water Resources, Missoula, Mont., June 26-28, 2006, Proceedings: American Water Resources Association, p. 1-6 (CD-ROM).

Palmer, S.C., Burbidge, C., and Patno, H., 2004, The financial impacts of the low summer steady flow experiment at Glen Canyon Dam: Salt Lake City, Utah, U.S. Department of Energy, Western Area Power Administration, CRSP Management Center, 32 p., accessed on August 23, 2011, at http://www.gcmrc.gov/library/reports/Other/GlenCanyonDam/Palmer2004b.pdf.

Patten, D.T., and Stevens, L.E., 2001, Restoration of the Colorado River ecosystem using planned flooding: Ecological Applications, v. 11, no. 3, p. 633-634, accessed on December 6, 
2010, at http://www.esajournals.org/doi/abs/10.1890/1051-

0761(2001)011\%5B0633\%3AROTCRE\%5D2.0.CO\%3B2.

Poff, N.L., Richter, B.D., Arthington, A.H., Bunn, S.E., Naiman, R.J., Kendy, E., Acreman, M., Apse, C., Bledsoe, B.P., Freeman M.C., Henriksen, J., Jacobson, R.B., Kennen, J.G., Merritt, D.M., O'Keeffe, J.H., Olden, J.D., Rogers, K., Tharme, R.E., and Warner, A., 2009, The ecological limits of hydrologic alteration (ELOHA) - a new framework for developing regional environmental flow standards: Freshwater Biology, v. 55, no. 1, p. 147-170, accessed on August 19, 2011, at http://dx.doi.org/10.1111/j.1365-2427.2009.02204.x.

Porter, M.E., 2002, Riparian vegetation responses to contrasting managed flows of the Colorado River in Grand Canyon, Arizona: Flagstaff, Northern Arizona University, M.S. thesis, 33 p. Protiva, F.R., Ralston, B.E., Stone, D.M., Kohl, K.A., Yard, M.D., and Haden, G.A., 2010, Effects of Glen Canyon Dam discharges on water velocity and temperatures at the confluence of the Colorado and Little Colorado Rivers and implications for habitat for young-of-year humpback chub (Gila cypha): U.S. Geological Survey Open-File Report 2010-1137, 24 p., accessed on July 27, 2010, at http://pubs.usgs.gov/of/2010/1137/.

Roberts, C.A., and Bieri, J.A., 2001, Impacts of low flows on recreational rafting traffic on the Colorado River in Grand Canyon National Park - final report: Flagstaff, Ariz., submitted to Bureau of Reclamation and U.S. Geological Survey, Grand Canyon Monitoring and Research Center, cooperative agreement no. CA8210-99-002, interagency acquisition no. 00-AA-404330, 18 p., accessed on August 23, 2011, at http://www.gcmrc.gov/library/reports/cultural/Recreation/roberts2001.pdf.

Robinson, A.T., Clarkson, R.W., and Forrest, R.E., 1998, Dispersal of larval fishes in a regulated river tributary: Transactions of the American Fisheries Society, v. 127, no. 5, p. 772-786, accessed on June 1, 2011, at http://www.tandfonline.com/doi/abs/10.1577/15488659\%281998\%29127\%3C0772\%3ADOLFIA\%3E2.0.CO\%3B2.

Rogers, R.S., Persons, W.R., and McKinney, T., 2003, Effects of a 31,000-cfs spike flow and low steady flows on benthic biomass and drift composition in the Lees Ferry tailwater: Arizona Game and Fish Department, cooperative agreement no. 1425-98-FC-22390, mod. 3, 26 p., accessed on August 23, 2011, at http://www.gcmrc.gov/library/reports/biological/Foodbase/ Rogers2003b.pdf.

Schmidt, J.C., Topping, D.J., Rubin, D.M., Hazel, J.E., Jr., Kaplinski, M., Wiele, S.M., and Goeking, S.A., 2007, Streamflow and sediment data collected to determine the effects of low summer steady flows and habitual maintenance flows in 2000 on the Colorado River between Lees Ferry and Bright Angel Creek, Arizona: U.S. Geological Survey Open-File Report 20071268, 79 p., accessed on March 17, 2010, at http://pubs.usgs.gov/of/2007/1268/.

Speas, D.W., Persons, W.R., Rogers, R.S., Ward, D.L., Makinster, A.S., and Slaughter, J.E., IV, 2004, Effects of low steady summer flows on rainbow trout in the Lee's Ferry tailwater, 2000: Phoenix, Arizona Game and Fish, submitted to U.S. Geological Survey, Grand Canyon Monitoring and Research Center, cooperative agreement no. 1425-98-FC-40-22690, 38 p., accessed on August 23, 2011, at http://www.gcmrc.gov/library/reports/biological/Fish_studies/ AZGame\&Fish/2004/Speas2004.pdf.

Topping, D.J., Schmidt, J.C., and Vierra, L.E., 2003, Computation and analysis of the instantaneous-discharge record for the Colorado River at Lees Ferry, Arizona-May 8, 1921, through September 30, 2000: U.S. Geological Survey Professional Paper 1677, 118 p., accessed on January 28, 2010, at http://pubs.usgs.gov/pp/pp1677/pdf/pp1677.pdf. 
Trammell, M., Valdez, R.A., Carothers, S.W., and Ryel, R., 2002, Effects of a low steady summer flow experiment on native fishes of the Colorado River in Grand Canyon - final report: Flagstaff, Ariz., SWCA, Inc. Environmental Consultants, submitted to U.S. Geological Survey, Grand Canyon Monitoring and Research Center, cooperative agreement no. 99-FC40-2260, 77 p. [Available upon request by contacting the Center Director, U.S. Geological Survey, Southwest Biological Science Center, 2255 N. Gemini Drive, Flagstaff, Ariz. 86001.]

Travnichek, V.H., Bain, M.B., and Maceina, M.J., 1995, Recovery of a warmwater fish assemblage after initiation of a minimum-flow release downstream from a hydroelectric dam: Transactions of the American Fisheries Society, v. 124, no. 6, p. 836-844, accessed on August 23, 2011, at http://www.tandfonline.com/doi/abs/10.1577/15488659\%281995\%29124\%3C0836\%3AROAWFA\%3E2.3.CO\%3B2.

U.S. Department of the Interior, 1995, Operation of Glen Canyon Dam Final Environmental Impact Statement: Salt Lake City, Utah, Bureau of Reclamation, Upper Colorado Region, 337 p.

U.S. Fish and Wildlife Service, 1995, Final Biological Opinion on the Operation of Glen Canyon Dam: Albuquerque, N. Mex., consultation no. 2-21-93-F-167, p. 56.

U.S. Geological Survey, 2010, National Water Information System (NWISWeb): U.S. Geological Survey database, accessed April 27, 2010, at http://waterdata.usgs.gov/nwis.

Valdez, R.A., and Carothers, S.W., 1998, The aquatic ecosystem of the Colorado River in Grand Canyon-Grand Canyon data integration synthesis final report: Flagstaff, Ariz., SWCA, Inc. Environmental Consultants, submitted to Bureau of Reclamation, 250 p. [Available upon request by contacting the Center Director, U.S. Geological Survey, Southwest Biological Science Center, 2255 N. Gemini Drive, Flagstaff, Ariz. 86001.]

Valdez, R.A., Carothers, S.W., House, D.A., Douglas, M.E., Ryel, R.J., Bestgen, K.R., and Wegner, D.L., 2000, A program of experimental flows for endangered and native fishes of the Colorado River in Grand Canyon-final report: Flagstaff, Ariz., SWCA, Inc., Environmental Consultants, submitted to U.S. Geological Survey, Grand Canyon Monitoring and Research Center, 68 p. [Available upon request by contacting the Center Director, U.S. Geological Survey, Southwest Biological Science Center, 2255 N. Gemini Drive, Flagstaff, Ariz. 86001.] Valdez, R.A., and Ryel, R.J., 1995, Life history and ecology of the humpback chub (Gila cypha) in the Colorado River, Grand Canyon, Arizona - final report.: Logan, Utah, BIO/WEST, Inc., submitted to Bureau of Reclamation, contract no. 0-CS-40-09110, technical report no. TR250-08, 329 p. [Available upon request by contacting the Center Director, U.S. Geological Survey, Southwest Biological Science Center, 2255 N. Gemini Drive, Flagstaff, Ariz. 86001.] Webb, J.A., Stewardson, M.J., and Koster, W.M., 2010, Detecting ecological responses to flow variations using Bayesian hierarchical models: Freshwater Biology, v. 55, no. 1, p. 108-126, accessed on August 23, 2011, at http://onlinelibrary.wiley.com/doi/10.1111/j.13652427.2009.02205.x/full.

Webb, R.H., Schmidt, J.C., Marzolf, G.R., and Valdez, R.A., eds., 1999, The 1996 controlled flood in Grand Canyon, v. 110: Washington, D.C., American Geophysical Union, Geophysical Monograph Series, $367 \mathrm{p}$.

Yard, M.D., Coggins, L.G., Baxter, C.V., Bennett, G.E., and Korman, J., 2011, Trout piscivory in the Colorado River, Grand Canyon--effects of turbidity, temperature, and fish prey availability: Transactions of the American Fisheries Society, v. 140, no. 2, p. 471-486, accessed on April 19, 2011, at http://www.tandfonline.com/doi/abs/10.1080/00028487.2011.572011. 


\title{
Appendix. Annotated Bibliography of Studies Conducted During 2000 Low Steady Summer Flow Experiment
}

\author{
Anima, R., Wong, F.L., Hogg, D. and Galanis, P., 2007, Side-scan sonar imaging of the \\ Colorado River, Grand Canyon: U.S. Geological Survey Open-File Report 2007-1216, 15 p., \\ accessed on August 23, 2011, at http://pubs.usgs.gov/of/2007/1216/.
}

\section{Overview}

The utility of side-scan sonar was evaluated for the examination of substrate changes (boulders, cobbles, pebbles, sand) in the Colorado River from the Glen Canyon Dam tailwaters to river mile 88 before (Aug. 28-Sept. 5, 2000) and after (Sept. 10-18, 2000) the September Habitat Maintenance Flow (HMF). The HMF was part of the 2000 Low Steady Summer Flow (LSSF) experiment and occurred in Period II of the experiment. Imaging focused on pools between rapids and smaller rapids where possible. The report presents the methods used and discusses how well the technology differentiates bed-material types from a subset of the data. Side-scan sonar can be used to look at overall changes in bed texture over an extended area, but there are caveats. Data density was high, which caused post-processing delays. Extreme canyon temperatures also affected instruments. Navigation control did not permit centimeter-scale change detection of bed material and required manual registration in the image-processing step.

\section{Results}

- Pixel resolution prohibited individual sand, pebble, and cobble identification, but sand as a class can be distinguished from other substrate classes.

- Pebbles were the predominant bed type in some reaches, particularly in Lees Ferry.

- Imagery showed changes at some sites, including either removal of sand, which exposed pebbles and cobbles, or aggradation of sand.

- Image distortion associated with heave and yaw of the underwater sensor and changes in boat speed were present.

This was a demonstration project and no attempt was made to summarize or quantify findings. Problems with the technology included post-processing problems with a large amount of data. Report includes a DVD subset of processed imagery as well as unprocessed imagery. Efficient data processing requires expertise with image processing. These data/methods may be applicable to nearshore fish habitat classification. Schmidt and others (2007) questioned the accuracy of this technique and state that "the small differences in the area of bed composed of boulders and bedrock illustrates the error associated with interpretation of side-scan sonar data and incorporation into a GIS." Schmidt and others (2007) suggest that the technique is more applicable to large-scale changes rather than centimeter-scale changes in bed material. 
Benenati, E.P., Shannon, J.P., Haden, G.A., Straka, K., and Blinn, D.W., 2002, Monitoring and research - the aquatic food base in the Colorado River, Arizona during 1991-2001—final report: Flagstaff, Arizona Game and Fish Department, U.S. Fish and Wildlife Service and Northern Arizona University, submitted to U.S. Geological Survey Grand Canyon Monitoring and Research Center, cooperative agreement no. 1452-98-FC-225590, 227 p.

\section{Overview}

The authors collected data associated with water quality, benthic biomass, organic drift, and a fish habitat selection experiment. Data were collected in June, August, September, and October of 2000 and compared with similar data collected in 1997 when discharges were higher but also steady. Macroinvertebrate biomass, except snails, was not significantly different from previous sample years. There were shifts in phytobenthic composition (aquatic macrophytes from Cladophora), which also was noted by Rogers and others (2003) in the Lees Ferry fishery. Coarse particulate organic drift values were similar to those recorded under higher sustained discharges in 1997.

Results

- Cladophora biomass increased on average between June and September, though its distribution was patchy.

- Biomas of miscellaneous benthos decreased overall. Comparison was made between June and October and cannot distinguish between seasonality versus the effect of the Low Steady Summer Flow Experiment.

- Macroinvertebrate biomass increased through the summer, predominantly because of snail density increases throughout the system.

- Simuliid larvae density decreased by 92 percent, but two sample sites were associated with Little Colorado River and August-September sampling may be affected by monsoonal spates.

- Drift biomass and density did not vary among sample periods but composition did.

- Values for organic drift were $14.0( \pm 0.91)$ milligrams per cubic meter per second at Lee Ferry. 
Davis, P.A., 2002, Evaluation of airborne thermal-infrared image data for monitoring aquatic habitats and cultural resources within the Grand Canyon: U.S. Geological Survey Open-File Report 02-367, 49 p.

\section{Overview}

Thermal-infrared (TIR) image data were acquired using the airborne Advanced Thematic Mapper (ATM) in the afternoon of July 25, 2000, over river miles (RM) 30-74. The Daedalus ATM 1268 was deployed, and the sensor collected data in 12 channels at a spatial resolution of $100 \mathrm{~cm}$. The ATM data were provided georectified in a Universal Transverse Mercator map projection (WGS84) with a positional accuracy of 2-3 m. The gain setting used for the ATM band 12 produced a temperature range of 1 to $83^{\circ} \mathrm{C}$. The range could be reduced by a factor of three and still capture the temperature range of the water with $0.1^{\circ} \mathrm{C}$ intervals. Data need to be acquired within a 2 -hour window of the maximum solar heating ( 1:30 p.m.) to provide maximum solar heating of the water and to minimize the cooling effects of late-afternoon shadows. The cost for acquiring TIR data is high $(\$ 620 /$ river kilometer $(\mathrm{km}))$ and does not include costs of ground calibration. The benefit of the approach is that it provides an instantaneous map of surface water temperatures for a $160 \mathrm{~km}$ stretch of the Colorado River.

Results

- Gradual downstream warming of surface water in the mainstem was visible following calibration of TIR data.

- Embayment at RM 34 shows surface temperatures about $4^{\circ} \mathrm{C}$ warmer than mainstem. Only the very nearshore exceeded $18^{\circ} \mathrm{C}$ because of small area of embayment.

- The debris fan at Tatahatsu Wash creates a low-velocity environment and indicated gradual increase in temperature reaching temperatures about $10^{\circ} \mathrm{C}$ greater than the mainstem.

- Cut-off backwaters warmed in excess of $25^{\circ} \mathrm{C}$ but these would be inaccessible to fish.

- TIR indicates temperature differential of tributaries and mainstem.

- Ground-truth calibration that compared TIR temperature data to Thermistor data collected on July 24,2000 , at RM 64 indicates airborne temperatures were $2{ }^{\circ} \mathrm{C}$ greater than Thermistor temperatures. Cloud cover on the July 24 may account for the observed temperature differential. 
Hjerpe, E., and Kim, Y.-S. 2003, Economic effects of summer steady flows on recreation:

Flagstaff, Northern Arizona University, School of Forestry, 21 p.

\section{Overview}

The authors investigated how the variable flows associated with the Low Steady Summer Flow (LSSF) experiment affected the economic operations of recreation-based industries. They extended their findings to the regional economy. Industries investigated include private whitewater boaters, anglers, and river concessionaires. Mail and in-person surveys were conducted. Aggregated LSSF-related expenses incurred by rafting concessionaires totaled more than $\$ 70,000$. Angling concessionaires benefitted slightly from improved fishing, though they did report a loss of $\$ 33,000$ because of the inability to conduct trips during the spike flows. An analysis of the regional cost of LSSF produced an estimate of $\$ 124,000$.

\section{Results}

- Angling concessionaires report losses during the May and September habitat maintenance flows because of the inability to conduct trips.

- Rafting concessionaires were more adversely affected by low flows than other groups. Losses totaled more than $\$ 70,000$. Volume of trips did not change.

- The low steady flows are blamed for three major boating accidents, one each at Horn Creek, Hance rapids, and Crystal rapids. Search and rescue operations associated with these accidents cost the National Park Service approximately $\$ 30,000$.

- Interviewed river guides indicate $226 \mathrm{~m}^{3} / \mathrm{s}$ (low steady level) is minimum flow level for passenger safety at Horn Creek, Hance rapids, and Crystal rapids.

- Longer "on-river" times because of low flows stressed river crews.

- Day-use rafting companies had minimal effect from the low flows.

- Increased "interest" in low flows among anglers and boaters negated any negative economic effects, including a few equipment-damaging incidents.

- Angling concessionaires saw a slight increase in the number of guided trips and revenue during the low-flow phase. 
Jonas, L.M., and Stewart, W.P., 2002, An overview of various impacts to Grand Canyon River experiences, with a focus on intergroup encounters, flow levels and the 2000 low summer steady flow experiment-final report: Flagstaff, Ariz., SWCA, Inc. Environmental Consultants, submitted to U.S. Geological Survey, Grand Canyon Monitoring and Research Center. [Available upon request by contacting the Center Director, U.S. Geological Survey, Southwest Biological Science Center, 2255 N. Gemini Drive, Flagstaff, Ariz. 86001.]

\section{Overview}

The study incorporated previous work associated with recreational attitudes among rafters along the Colorado River to identify the physical and social-psychological attributes that contribute to Grand Canyon river experiences. To evaluate the effect of flow levels, the authors also identified specific attributes affected by flow levels and provided a perspective of the effect the Low Steady Summer Flow (LSSF) experiment had on group experiences. Through a literature review, the authors concluded that although the LSSF experiment reduced the rate of travel, decreased the size of rapids, increased safety concerns, and improved the quality of camping beaches. The overall effects on user experience are considered minor because $226 \mathrm{~m}^{3} / \mathrm{s}$ is not considered an extreme low flow. Furthermore, because the river experience is multidimensional, many other factors were minimally or not affected by the experimental flows and did not affect river experiences.

\section{Results}

- Flows below $226 \mathrm{~m}^{3} / \mathrm{s}$ are considered less safe and lead to more boating accidents.

- Much of the data were collected in late 1980s and early 1990s when boaters were not exposed to lower flows, so the point of reference is different.

- Motorized rafts experienced much higher accident rates than oar-powered boats during the low steady flows (Jalbert, 2001).

- Low flows increase campable area.

- Steady flows allow camping near the edge of the water.

- At flows like the low steady flow, below $283 \mathrm{~m}^{3} / \mathrm{s}$, boatmen had to row more or run the motor longer to meet schedules.

- At flows above 877 cubic meters per second, like the September spike, boatmen can row or run motors less

- Interactions between research and commercial trips can be improved by engaging commercial passengers. 
Korman, J., Wiele, S.M., and Torizzo, M., 2004, Modelling effects of discharge on habitat quality and dispersal of juvenile humpback chub (Gila cypha) in the Colorado River, Grand Canyon: River Research and Applications, v. 20, no. 4, p. 379-400, accessed on February 22, 2010, at http://www3.interscience.wiley.com/cgi-bin/fulltext/107614374/PDFSTART.

\section{Overview}

The authors used a two-dimensional hydrodynamic model to evaluate how Glen Canyon Dam operations affect the availability of shoreline habitats and dispersal of juvenile humpback chub (Gila cypha). The study considered seven reaches within a $3.6 \mathrm{~km}$ area near the confluence of the Colorado and Little Colorado Rivers. Suitable habitat, defined by velocities and depths from historical electrofishing data, generally declined at discharges less than $226 \mathrm{~m}^{3} / \mathrm{s}$ and greater than $425 \mathrm{~m}^{3} / \mathrm{s}$, though this pattern was not consistent among all reaches.

Results

- Total suitable shoreline habitat generally declined with increasing discharge, but the response was variable among reaches and was affected by local morphology.

- Reaches that indicated little response were dominated by large fan-eddy complexes in which low-velocity eddies are maintained as discharges increase.

- Highly responsive reaches had low-profile fans that were overtopped at $425 \mathrm{~m}^{3} / \mathrm{s}$ discharges.

- Availability of habitat when stratified by substrate type varied among reaches. Talus and debris fan habitats might stay constant, whereas vegetated shorelines increased with increasing discharges to $1,272 \mathrm{~m}^{3} / \mathrm{s}$.

- The LSSF flows in June and July presented high suitable shoreline habitat that was not available during predam flows (months of when suitable habitat was lowest).

- Operations have generally increased habitat in the spring, but reduced it in the months of August-February.

- Physical retention of randomly placed particles simulating the movement of juvenile humpback chub tended to decline with increasing discharge, though this pattern varied considerably because of differences in local morphology among reaches. Retention rates were greatest in reaches where eddies made up a large proportion of the wetted area. 
Palmer, S.C., Burbidge, C., and Patno, H., 2004, The financial impacts of the low summer steady flow experiment at Glen Canyon Dam: Salt Lake City, Utah, U.S. Department of Energy, Western Area Power Administration, CRSP Management Center, 32 p., accessed on August 23, 2011, at http://www.gcmrc.gov/library/reports/Other/GlenCanyonDam/Palmer2004b.pdf.

\section{Overview}

The authors explain the methods used to estimate the financial cost of the Low Steady Summer Flow (LSSF) experiment on Western Area Power Administration (Western) and its electrical service customers, describing the change in Glen Canyon Dam operations and the power system effects of the LSSF experiment. The report is strictly a financial study pertaining to Western and its electrical customers. Costs associated with the LSSF are considered nonreimbursable funds to the U.S. Treasury. The authors distinguish between financial and economic analyses, stating a financial-impact study focuses on the impact of an action on an individual body or institution and that an economic analysis describes the effect of an action on the society as a whole. The estimated cost of the LSSF experiment of 2000 to Federal power users was $\$ 32$ million. Though some of the inflow deficit from the experiment was recovered as of December 2004, a storage deficit remains due, in part, to ongoing drought.

\section{Results}

- Cost associated with the LSSF were nonreimbursable and are not repayable to the U.S. Treasury, but these funds are credited against reimbursable costs.

- Monthly water budgets were redistributed between March 2000 and November 2000 to alleviate the financial costs associated with low water inflows and existing market power costs and the LSSF experiment (funds to support the science studies).

- Used two test case scenarios against the base case scenario: (1) actual water releases and Glen Canyon Dam constraints in the Hydro LP model for an optimized generation pattern and (2) actual generation pattern data from Supervisory Control and Data Acquisition (SCADA) to compare the optimized model results against reported values of generation from six Colorado River Storage Project units.

- The hourly difference between the test cases and base case generation is multiplied by the month's on- or off-peak price. The difference in purchases and sales is summed by month.

- Base case is the monthly water volumes releases in the absence of the LSSF and load values were based on historical values.

- Power purchase is usually in seasonal firm blocks rather than on the spot market. Additional power when needed is purchased on spot market on day-before basis.

- April and May releases were greater under LSSF than base case, so Western had a net financial gain by selling surplus power (\$3.6 and \$6.8 million in April and May, respectively).

- June-August releases were lower than base case and Western had to make purchases to meet demand.

- More than normal release of water in water year (WY) 2000 and subsequent years of minimum water delivery to the lower basin states because of low inflows add to financial costs to Western.

- Total financial cost was slightly less than \$32 million. 
Porter, M.E., 2002, Riparian vegetation responses to contrasting managed flows of the Colorado

River in Grand Canyon: Flagstaff, Northern Arizona University, M.S. thesis, 33 p.

\section{Overview}

The author examined patterns of establishment and survival of native and nonnative plants along the shoreline during two contrasting discharge patterns. Greenhouse experiments also were used to verify field observations. Sampling plots were established along the Colorado River corridor between Lees Ferry and river mile 68.0, which is just downstream from the confluence of the Colorado and Little Colorado Rivers. Data collection took place during Periods II and III and again in the following year during fluctuating discharges. Seedling (tamarisk (Tamarix spp.)) and asexual propagule (wetland species) densities increased for native and nonnative species, particularly tamarisk during the steady-flow period. The habitat maintenance flow (HMF) in September reduced tamarisk seedling densities by 60 percent, although horsetail (Equisetum) shoots were not significantly affected. Data from plots sampled under fluctuating discharges the following summer indicate that tamarisk densities continued to decline and horsetail stem density continued to increase. Water table declines associated with changes in discharges between Periods I and II contributed to mortality of plants located above the $226 \mathrm{~m}^{3} / \mathrm{s}$ stage elevation.

\section{Results}

- High densities of tamarisk seedlings were established at mid-shore elevations during the low steady flow phase. Stem density averaged 626 stems per square meter by August 2000.

- Numbers of Equisetum and other native plants also increased, though to a lesser degree, during the same period.

- Existing horsetails at the spike-flow water line suffered 55 percent mortality during June and July 2000.

- Tamarisk numbers declined by 57 percent following the September HMF (626 stems per square meter to 264 stems per square meter).

- Densities in tamarisk after April 2001 were equivalent to June 2000 levels.

- Clonal expansion density patterns of horsetails showed greater densities in the upper shore region. 
Protiva, F.R., Ralston, B.E., Stone, D.M., Kohl, K.A., Yard, M.D., and Haden, G.A., 2010, Effects of Glen Canyon Dam discharges on water velocity and temperatures at the confluence of the Colorado and Little Colorado Rivers and implications for habitat for young-of-year humpback chub (Gila cypha): U.S. Geological Survey Open-File Report 2010-1137, 24 p., accessed on July 27, 2010, at http://pubs.usgs.gov/of/2010/1137/.

\section{Overview}

This study determined the amount of warmwater, low-velocity environments available to young-of-year (30-90 mm) humpback chub (Gila cypha) in the vicinity of the confluence of the Colorado and Little Colorado Rivers (LCR) during the 2000 Low Steady Summer Flow (LSSF) experiment flow regimes. This study quantified environments that had velocities and temperatures identified suitable for young of year humpback chub at discharges of $227 \mathrm{~m}^{3} / \mathrm{s}, 368$ $\mathrm{m}^{3} / \mathrm{s}, 504 \mathrm{~m}^{3} / \mathrm{s}$, and $878 \mathrm{~m}^{3} / \mathrm{s}$. Discharges as much as $368 \mathrm{~m}^{3} / \mathrm{s}$ provided the greatest area of suitable habitat around the island located at the confluence of the mainstem and LCR. Suitable environments that meet temperature and velocity requirements were reduced above this discharge.

Results

- The island and the confluence sets up circulation dynamics that affect how the mainstem Colorado River travels. Under $227 \mathrm{~m}^{3} / \mathrm{s}$ discharges, the mainstem flow is diverted to the west of the island and does not interact to a great extent with LCR discharge.

- At higher discharges, like that during the habitat maintenance flow $\left(1,165 \mathrm{~m}^{3} / \mathrm{s}\right)$, the mainstem flows around the island and there is no suitable habitat at the confluence area. Ponding does occur.

- The greatest area of suitable habitat within the confluence area occurred at discharges as much as $368 \mathrm{~m}^{3} / \mathrm{s}$ when mainstem volumes pool slightly at the upstream side of the LCR mouth/mainstem confluence and force the LCR water to the lower part of the island, which increases volume and concentrates the warmer water discharging from the LCR. 
Roberts, C.A., and Bieri, J.A., 2001, Impacts of low flows on recreational rafting traffic on the Colorado River in Grand Canyon National Park-final report: Flagstaff, Ariz., submitted to Bureau of Reclamation and U.S. Geological Survey, Grand Canyon Monitoring and Research Center, cooperative agreement no. CA8210-99-002, interagency acquisition no. 00-AA-404330, 18 p., accessed on August 23, 2011, at http:/www.gcmrc.gov/library/reports/cultural/ Recreation/roberts2001.pdf.

\section{Overview}

The authors compared trip reports from 600 private and commercial permit holders from three rafting seasons that included fluctuating flows and the steady flow of 2000. Distribution of data collection was shared between authors and Linda Jalbert of National Park Service Science Center at Grand Canyon National Park. Base flow rate affects time spent at attraction sites, campsite selection, and time spent on the river. Results indicate 50 percent less time was spent on off-river activities during the steady-flow period.

\section{Results}

- All boats were slowed to some extent during the steady-flow period. Oar-powered boat speed is affected greatest by discharge.

- The amount of time boats spent on the river, in campsite selection, and in selection of and time spent at attraction sites were all affected by the Low Steady Summer Flow experiment.

- Number of off-river activities did not change, but on average, trips spent 50 percent less time engaged in off-river activities during the low summer steady flow period.

- Attraction site preference did not change.

- More camps became available during Period II. 
Rogers, R.S., Persons, W.R., and McKinney, T., 2003, Effects of a 31,000-cfs spike flow and low steady flows on benthic biomass and drift composition in the Lees Ferry tailwater: Arizona Game and Fish Department, cooperative agreement no. 1425-98-FC-22390, mod. 3, 26 p., accessed on August 23, 2011, at http://www.gcmrc.gov/library/reports/biological/Fish_studies/ AZGame\&Fish/2004/Speas2004.pdf.

\section{Overview}

This study measured the effects of the Period II and May and September habitat maintenance flow (HMF) on benthic biomass and drift in the Lees Ferry area. The authors provide comparisons of biomass with data from 1992-97. The authors attribute differences in biomass to compositional shifts in macrophytes that occurred between 1996 and 2000. Chironomidae densities were greater in 2000 than in previous years. Previous studies have indicated that short-term spike flows can reduce aquatic resources such as macrophytes and levels of chlorophyll $a$ in periphyton. Reductions in organic drift are associated with steady discharges.

Results

- Following the May HMF, periphyton ash-free dry mass concentrations from grab samples did not differ significantly throughout the experiment with a peak in the July/August sample period.

- Grab samples of macrophyte increase significantly through July with highest relative abundance observed in June and September.

- Macroinvertebrate densities did not decline in association with the HMF. Gammarus densities increased and were significantly higher in the September 11, 2000, period than during previous sampling times.

- Chironomidae densities increased with time and were significantly higher in July than in either April or September.

- New Zealand mudsnail (Potamopyrgus antipodarum) densities increased throughout the experiment.

- Invertebrate drift did decrease significantly following the May HMF. Gammarus disappeared from drift samples after mid-May.

- Periphyton and macrophyte ash-free dry mass concentrations, chlorophyll $a$, and benthic macroinvertebrates were all higher during the steady flows.

- Invertebrate drift peaked in July and then decreased subsequently.

- Invertebrate drift declined after the September HMF, as measured until November 2000. 
Schmidt, J.C., Topping, D.J., Rubin, D.M., Hazel, J.E., Jr., Kaplinski, M., Wiele, S.M., and Goeking, S.A., 2007, Streamflow and sediment data collected to determine the effects of low summer steady flows and habitual maintenance flows in 2000 on the Colorado River between Lees Ferry and Bright Angel Creek, Arizona: U.S. Geological Survey Open-File Report 20071268, 79 p., accessed on March 17, 2010, at http://pubs.usgs.gov/of/2007/1268/.

\section{Overview}

The authors used the experimental hydrograph to test methods to measure influx, efflux, and change in fine-grained sediment distribution in Marble Canyon and eastern Grand Canyon to Phantom Ranch (river mile (RM) 0- 89). Segments (3-8 kilometers long) within geomorphic reaches were used to determine if storage and evacuation varied longitudinally. Changes in finesediment storage were determined using a combination of aerial photography analyses and ground surveys. Gaging stations were used to measure discharge and sediment supplied by tributaries. Sand accumulated in mid-elevation zones and decreased in low-elevation zones in eddies during the habitat maintenance flows (HMF). This pattern reversed during the summer low flows. There was substantial site-to-site variation in sand movement and accumulation. Because of limited tributary flow in 2000, the predominant source of fine sediment exported from Marble Canyon during September HMF was from eddy sandbars. Overall, the Low Steady Summer Flow (LSSF) experiment did increase mid-elevation zone volume and areas of fine sediment in eddy sandbars, though the increases were smaller than increases measured since 1984.

\section{Results}

- Sand supply in Marble Canyon was greater during the May HMF than the September HMF. Although silt and clay concentrations were comparable between the two high flows, sand concentrations were 30 percent lower during September than May.

- Approximately 80 percent of suspended sand during the September HMF was from sources upstream from RM 30. There also was an increase in suspended clay and silt downstream from the Little Colorado River.

- More than half of the sand from RM 30 during September 2000 originated between the Paria River and RM 10.

- Sand accumulated in mid-elevation zones and decreased in low-elevation zones during the May HMF. Increases were smaller than any measured since 1984.

- During summer steady flows, sediment accumulated at low elevations and declined at mid-elevations in eddies. The mass balance for sand was positive during the low steady summer flow phase.

- Sand accumulated in mid-elevation zones and decreased in low-elevation zones during the September HMF, though not to the same extent as during the May HMF, because of low sediment input from tributaries during summer 2000.

- Mid-elevation fine sediment deposits typically were eroded during the steady flow period, as average volume decreased from 924 to $698 \mathrm{~m}^{3}$ in upper Marble Canyon and from 2,697 to 2,315 $\mathrm{m}^{3}$ in lower Marble Canyon.

- The total area of backwater habitat increased in nearly all reaches during the September HMF. Number and total area of backwaters in each reach in September were comparable to those of 1984. 
- During May and September HMFs, upstream sediment supplies were depleted and suspended sediments coarsened. The same pattern occurred during the 1996 controlled flood and an HMF in 1997.

- The mean grain size of the fine sediment on the surface of the bed coarsened because of the September HMF (12 of 15 sites coarsened). Fine sediment coarsened by an average of $0.16 \mathrm{~mm}$ in the upper $93 \mathrm{~km}$ of the study area.

- Accumulation occurred only during the steady flow period. Influxes of tributary fine sediment were transported past the lower Marble Canyon gaging station (station number 09383100) within several months after tributary inflows. Because tributary influxes of fine sediment were lower than average in 2000, less sand accumulated during the steady flow period than was eroded during the May HMF.

- The overall effects of the LSSF experiment were not significantly different among upper and lower Marble Canyon and upper Grand Canyon. Therefore, no longitudinal differences were noted in eddy sandbar response or the relative proportion of fine sediment transferred among the bed, eddy sandbars, or channel-margin deposits from ground surveys.

- An increase in sandbar area occurred following the September HMF, as indicated by measurements of area and volume in upper and lower Marble Canyon from ground surveys. Following the September HMF, the Lees Ferry reach experienced more erosion - relative to deposition - than any other reach. 
Speas, D.W., Persons, W.R., Rogers, R.S., Ward, D.L., Makinster, A.S., and Slaughter, J.E., IV, 2004, Effects of low steady summer flows on rainbow trout in the Lee's Ferry tailwater, 2000: Phoenix, Arizona Game and Fish, submitted to U.S. Geological Survey, Grand Canyon Monitoring and Research Center, cooperative agreement no. 1425-98-FC-40-22690, 38 p., accessed on August 23, 2011, at http://www.gcmrc.gov/library/reports/biological/Fish_studies/ AZGame\&Fish/2004/Speas2004.pdf.

\section{Overview}

Rainbow trout in the Lees Ferry reach were sampled by electrofishing to assess fish density, population structure, and relative condition. Seasonal comparisons with previous years of data (1991-99) were conducted and stomach contents also were studied. The sampling regime encompassed the different periods of the Low Steady Summer Flow (LSSF) experiment, but data were interpreted relative to seasonal trends, such that winter (March), spring (June), summer (August) and fall (November) seasons were represented. Seasonal variance of catch effort, relative condition, and proportional stock density were used in relation to the hydrologic components of the LSSF experiment. Null hypotheses and fish metrics (above) were presented relative to data from 1991-99 rather than specifically to periods associated with the LSSF experiment. The authors concluded that there were minimal immediate effects from the LSSF experiment on the trout fishery. Greatest differences were in time of occurrence of fish less than 152 millimeters (mm) (April in 2000 compared to June in previous years). Authors suggest gains in survival of age 1+ year fish associated with stable flows might be offset by reduced habitat at 226 cubic meters per second stage elevation.

\section{Results}

- Age-0 year trout appeared in catch during April through June, which was 3 months earlier than during 1991-99

- Relative condition of all size categories except fish more than $350 \mathrm{~mm}$ peaked during spring 2000 (including June for this study), though it peaked in summer in previous years (July-September)

- Large numbers of unusually small Age-0 year trout (50-75 mm total length (TL) were collected during June and September, suggesting that the May habitat maintenance flow did not affect small-sized trout

- There were more Age-0 year trout (50-75 mm TL) caught in 2000 than in all previous years combined

- Catch per unit effort (CPUE) of age-1 year trout did not decline following the September habitat maintenance flow

- CPUE of age-1 year fish was lowest during autumn and winter, 2000 (nonsignificant trend)

- CPUE of stock-size fish declined in December (nonsignificant trend)

- Proportional stock density did not vary through seasons, though it peaked significantly in winter months during previous years

- The relative condition of larger trout (greater than $405 \mathrm{~mm}$ ) continued to decline in 2000

- Instantaneous growth rates in rainbow trout declined by 92 percent since 1991, and growth was lower in 2000 than in previous years 
- The number of fish with empty stomachs did not differ from previous years; however, there was a large increase in the proportion of larger trout with empty stomachs

- Stomach contents included a higher volume of Gammarus and gastropods than in 1999 
Trammell, M., Valdez, R.A., Carothers, S.W., and Ryel, R., 2002, Effects of a low steady summer flow experiment on native fishes of the Colorado River in Grand Canyon-final report: Flagstaff, Ariz., SWCA, Inc. Environmental Consultants, submitted to U.S. Geological Survey, Grand Canyon Monitoring and Research Center, cooperative agreement no. 99-FC40-2260, 77 p. [Available upon request by contacting the Center Director, U.S. Geological Survey, Southwest Biological Science Center, 2255 N. Gemini Drive, Flagstaff, Ariz. 86001.]

\section{Overview}

Species composition, relative abundance, and fish distribution data were collected using shoreline electrofishing, mark-recapture methods, seining, hoop nets, and trammel nets. Sampling trips occurred in June, August, September, and December 2000. Study sites extended from Lees Ferry to Diamond Creek. Mark-recapture population-estimate studies occurred from Crash Canyon to Carbon Creek, at Middle Granite Gorge, and at Kanab Creek. Rainbow trout (Oncorhynchus mykiss) was the most abundant species in the upper reaches and dominated the electrofishing and netting catch effort. Species representation shifted in the lower sections of the canyon. Fathead minnows (Pimephales promelas) and speckled dace (Rhinichthys osculsus) were the dominant species farther downstream. Catch per unit effort (CPUE) of bluehead suckers (Catostomus discobolus) and flannelmouth suckers (C. latipinnis) increased in August compared to 1991-97. The September habitat maintenance flow caused a reduction in the CPUE of all species, but CPUE for native fishes remained higher than in previous years, whereas CPUE for fathead minnows was comparable to previous years. Multiple sampling efforts and gear types were employed to evaluate the Low Steady Summer Flow (LSSF) experiment effects, with variable results.

\section{Results}

- Relative abundances and composition of fish were not significantly different between trips but did vary by reach.

- Most flannelmouth suckers, bluehead suckers, and speckled dace were captured below river mile 150 .

- Native species were found in greater percentages (49.2 percent of total number) in trammel net sets than electrofishing samples.

- More fishes were captured in seine hauls than other gear types.

- 370 seine hauls were made in 243 backwaters collecting a total of 18,309 fish representing 11 species.

- The greatest number of fish caught in backwaters (72 percent) was in August 2000.

- Composition, total abundance, and relative abundance varied seasonally and longitudinally.

- Order of abundance of five most common fish: fathead minnow more than speckled dace were more than bluehead sucker were more than flannelmouth sucker were more than humpback chub. Humpback chub was a small percentage of the total number.

- The highest proportion of native fish in backwaters was found in June and the lowest in August; however, August catch rates of flannelmouth and bluehead suckers were significantly higher than in previous years.

- Mean CPUE of fishes captured by seining compared with previous years did not differ markedly, but total abundance increased for all species except humpback chub. 
- Following the September habitat maintenance flow, fathead minnow numbers were comparable to previous years values, whereas flannelmouth and bluehead sucker numbers were higher than previous years.

- Length histograms show overlap between age-0 year and age-1 year fish making growth rates difficult to assess.

- Maximum lengths did not appear to increase during the LSSF experiment.

- Protracted spawn and influx of newly hatched larvae depressed mean total sample length in September.

- Mean total lengths of fish captured in 2000 were similar to August and September lengths in 1991-97.

- There is evidence that nonnative fish including the fathead minnow and largemouth bass (Micropterus salmoides) spawned in the mainstem upstream from Diamond Creek. There was no record of largemouth bass reproducing upstream from Diamond Creek before 2000.

- Temperatures were greatest downstream from the Little Colorado River and in August 2000. LSSF temperatures were warmer than those measured during Modified Low Fluctuating Flow operations between 1991 and 1994. Mainstem mean temperature during June 2000 reached $16^{\circ}$ by RM 130 . 
Yard, M., and Blinn, D.W., 2001, Algal colonization and recolonization response rates during experimental low summer steady flows - final report: Flagstaff, Ariz., Northern Arizona University, submitted to U.S. Geological Survey, Grand Canyon Monitoring and Research Center, 54 p., accessed on August 23, 2011, at http://www.gcmrc.gov/library/reports/ biological/foodbase/Yard2001.pdf.

\section{Overview}

This study measured the effect of different substrate treatments on colonization and growth of the phytobenthic and invertebrate community during steady flows (Period II). The study used experimental treatments to evaluate whether the degree of substrate conditioning and atmospheric exposure to desiccation affected the mode of colonization; community composition; and accretion rates for the periphyton and invertebrate composition, density, and biomass. The primary mode of periphyton colonization was through zoospore propagation and secondarily through fragmentation. Rapid periphyton growth occurred for non-desiccated substrate; however, biomass did not attain biomass levels that were equivalent to control. The results of the study suggested that grazing pressure from New Zealand mudsnail (Potamopyrgus antipodarum) may have had effects on periphyton colonization modes, structure, and composition and rates of invertebrate colonization, at least under the constant flow conditions of this experiment.

\section{Results}

- Cladophora colonized treatments differentially, which were by composition 3 percent for Time 1 (T1), 16 percent for Time 2 (T2), and 85.8 percent for Time 3 (T3) measurements. The remaining periphyton were composed of unbranched filamentous forms (Ulothrix, Mougeotia, and Spirogyra).

- There were significant differences in algal growth rates between treatments: T1 $(0.008$ grams per square meter per day; $\left.\mathrm{g} / \mathrm{m}^{2} \bullet \mathrm{d}\right), \mathrm{T} 2\left(0.024 \mathrm{~g} / \mathrm{m}^{2} \bullet \mathrm{d}\right)$, and T3 $\left(0.93 \mathrm{~g} / \mathrm{m}^{2} \bullet \mathrm{d}\right)$. Growth differences between treatments suggested a positive effect from either residual holdfasts that remained viable or substrate conditioning.

- During the sampling period the mean maximum grams of ash-free dry mass (AFDM) observed for periphyton between the treatments was 2.5 grams per square meter $\left(\mathrm{g} / \mathrm{m}^{2}\right)$ (T1) $\pm 1.3 \mathrm{SE}$ (93 days), $4.8 \mathrm{~g} / \mathrm{m}^{2}$ (T2) $\pm 1.6 \mathrm{SE}$ (103 days), and $59.1 \mathrm{~g} / \mathrm{m}^{2}$ (T3) $\pm 7.3 \mathrm{SE}$ (71 days).

- For treatment T3, detritus accumulated in significant quantities at a rate of $1.1 \mathrm{~g} / \mathrm{m}^{2} \bullet \mathrm{d}$ and reached levels of $49.4 \mathrm{~g} / \mathrm{m}^{2} \pm 19$ SE by 60 days. Detritus accumulation was insignificant for the other two treatments.

- Total biomass (periphyton, macrophytes, and bryophytes) for the control averaged 176 $\mathrm{g} / \mathrm{m}^{2} \pm 5 \mathrm{SE}$, and Cladophora comprised 53.4 percent of the algal composition.

- The control also accumulated detritus throughout the sampling period. Detritus consisted of sloughed or senescent algal material and averaged $45.7 \mathrm{~g} / \mathrm{m}^{2} \pm 3.8 \mathrm{SE}$, with a maximum biomass of $69 \mathrm{~g} / \mathrm{m}^{2} \pm 16 \mathrm{SE}$ attained by 60 days.

- New Zealand mud snail was the dominant invertebrate, which attained maximum densities of $25.8 \cdot 10^{3} \mathrm{~g} / \mathrm{m}^{2} \pm 8.2 \cdot 10^{3} \mathrm{SE}$ (92 days), and $35.5 \cdot 10^{3} \mathrm{~g} / \mathrm{m}^{2} \pm 9.3 \cdot 10^{3} \mathrm{SE}(105$ days), and $129.7 \cdot 10^{3} \mathrm{~g} / \mathrm{m}^{2} \pm 22 \cdot 10^{3} \mathrm{SE}$ (49 days), for the respective treatments $\mathrm{T} 1, \mathrm{~T} 2$, and $\mathrm{T} 3$. 
- The control substrate attained the highest New Zealand mud snail densities observed at $217 \cdot 10^{3} \mathrm{~g} / \mathrm{m}^{2} \pm 19.5 \cdot 10^{3} \mathrm{SE}$ (60 days).

- In addition to snails, flatworms (Turbellaria) initially colonized treatments and reached mean densities of $214 \mathrm{~g} / \mathrm{m}^{2} \pm 46 \mathrm{SE}, 326 \mathrm{~g} / \mathrm{m}^{2} \pm 62$, and $1.2 \cdot 10^{3} \mathrm{~g} / \mathrm{m}^{2} \pm 0.14 \cdot 10^{3} \mathrm{SE}$ for $\mathrm{T} 1, \mathrm{~T} 2$, and $\mathrm{T} 3$, respectively.

- For treatment T3, chironomids appeared to have a negative response to increasing snail and flatworm densities. Chironomid reached maximum densities of $1.1 \cdot 10^{3} \mathrm{~g} / \mathrm{m}^{2}$ $\pm 0.45 \cdot 10^{3} \mathrm{SE}$ by 60 days and then rapidly decreased to minimal levels.

- Algal growth differences between treatments suggest that algal susceptibility to snail grazing may have been dependent on the colonization modes at earlier stages of development.

\section{References}

Jalbert, L., 2001, The effects of low steady summer flows on whitewater boating safety in Grand Canyon National Park - presentation to the Glen Canyon Dam Adaptive Management Program, in Colorado River Ecosystem Science Symposium, Flagstaff, Ariz., April, 2001.

Rogers, R.S., Persons, W.R., and McKinney, T., 2003, Effects of a 31,000-cfs spike flow and low steady flows on benthic biomass and drift composition in the Lees Ferry tailwater: Arizona Game and Fish Department, cooperative agreement no. 1425-98-FC-22390, mod. 3, 26 p., accessed on August 23, 2011, at http://www.gcmrc.gov/library/reports/biological/Foodbase/ Rogers2003b.pdf.

Schmidt, J.C., Topping, D.J., Rubin, D.M., Hazel, J.E., Jr., Kaplinski, M., Wiele, S.M., and Goeking, S.A., 2007, Streamflow and sediment data collected to determine the effects of low summer steady flows and habitual maintenance flows in 2000 on the Colorado River between Lees Ferry and Bright Angel Creek, Arizona: U.S. Geological Survey Open-File Report 20071268, 79 p., accessed on March 17, 2010, at http://pubs.usgs.gov/of/2007/1268/. 
